Andrews University

Digital Commons @ Andrews University

1981

\title{
A Description and Analysis of The Role of The Local Seventh-day Adventist Conference Communication Director in The United States
}

Daryl Louis Meyers

Andrews University

Follow this and additional works at: https://digitalcommons.andrews.edu/dmin

Part of the Practical Theology Commons

\section{Recommended Citation}

Meyers, Daryl Louis, "A Description and Analysis of The Role of The Local Seventh-day Adventist Conference Communication Director in The United States" (1981). Professional Dissertations DMin. 464. https://dx.doi.org/10.32597/dmin/464

https://digitalcommons.andrews.edu/dmin/464

This Project Report is brought to you for free and open access by the Graduate Research at Digital Commons @ Andrews University. It has been accepted for inclusion in Professional Dissertations DMin by an authorized administrator of Digital Commons @ Andrews University. For more information, please contact repository@andrews.edu. 


\section{ABSTRACT}

A DESCRIPTION AND ANALYSIS OF THE ROLE OF THE LOCAL SEVENTH-DAY ADVENTIST CONFERENCE COMMUNICATION DIRECTOR IN THE UNITED STATES

by

Daryl Louis Meyers

Chairman: James David Chase 


\section{ABSTRACT OF GRADUATE STUDENT RESEARCH \\ Project Report}

Andrews University

Seventh-day Adventist Theological Seminary

Title: A DESCRIPTION AND ANALYSIS OF THE ROLE OF THE LOCAL SEVENTHDAY ADVENTIST CONFERENCE COMMUNICATION DIRECTOR IN THE UNITED STATES

Name of researcher: Daryl Louis Meyers

Name and degree of chairman: James David Chase, D.Min.

Date completed: August 1981

Problem

Although the General Conference Communication Department has a plan of action outlined for local conference communication directors, a clearly stated rationale for this department as to its place in the evangelistic strategem of the church has yet to be developed.

The purpose of this study, therefore, was to provide the laity, church pastors, local conference communication directors, and conference presidents with a better understanding of the place for and duties of a trained conference communication director in an evangelistic context. 


\section{Method}

Interviews with several professionals in communication, a study of the General Conference role description for conference communication directors, and a pre-questionnaire sent to fifty denominational workers in the United States gave the researcher the data needed for his design of the three surveys used in this study. These surveys or questionnaires--previously sent to thirty Andrews University faculty members for their advice and counsel--were sent to 111 conference presidents, all conference communication directors, and a random sampling of 354 pastors in the United States. The information received from these respondents, coupled with the researcher's own studies into theological and communication source materials and his contact with PR professionals, served as the information base for this study.

\section{Results}

The results of the project were as follows:

1. The respondents generally are concerned about the communication director having sufficient "time" for his work, due to his responsibilities for other departments in addition to his own.

2. Communication directors and presidents see conference communication directors as being engaged in up to 33 percent more activities in one month than that perceived by pastors. These findings seem to indicate that pastors generally receive less assistance from their communication directors than the communication directors themselves and conference presidents seem to think they receive. 
3. The majority of the respondents consider the work of the communication director as "indirect evangelism in terms of image-building" (76.08 percent) rather than "seed-sowing evangelism" (46.33 percent). Thus most of the respondents appear to view the work of the communication director as more of a framework for or reinforcement to evangelism than a part of the evangelistic process itself.

4. Indications from the survey are that approximately 80 percent of 211 of the respondents had their training in theology or religion. Apparentiy due to this factor, all three groups see the need for communication directors to gain additional training in communication. This is especially emphasized by the communication directors themselves who give a higher response than either pastors or conference presidents in fifteen out of the nineteen categories noted in the survey concerning the professional or specialized training needed by communication directors.

5. The survey also indicates that a majority of the respondents see the communication department as being "approximately equal in importance to other conference departments" (40.65 percent) with a number from each group saying that it "could be" the "most important" department if it were perceived as such and were organized accordingly. However, these views are counterbalanced to some extent by those from all three groups who considered the department either "optional" (6.90 percent) or "less important" (14.64 percent) than other departments of the conference.

6. Even though a majority of the pastors say they are "we11-acquainted" (63.66 percent) with the communication director, 
indications from the survey as a whole show that in many of the conferences, regardless of this acquaintance, relatively little assistance in communications is given to the pastors.

7. Results from the survey also indicate that a high percentage of the activities conference communication directors are involved in during a typical three-month period are office oriented rather than people oriented. These activities include writing (73.47 percent), photo coverage of church-related events (65.31 percent), preparation of resource and promotional materials (26.53 percent), and editing (14.29 percent).

\section{Conclusion}

The results of the study clearly indicate that local conference presidents, pastors, and communication directors themselves are relatively uncertain about the role and evangelistic value of the communication director in the local conference.

This uncertainty appears to emerge from two primary causes: (1) the lack of time available to communication directors to do their work adequately, since most oversee one to three other departments as well, and (2) the lack of previous training for their position which in some respects tends to hinder their perceived and actual effectiveness in certain areas in which they otherwise would be considered experts (such as teaching pastors how to write for the news media or how to design radio or television spots).

The researcher concludes that in order for local conference communication directors to serve their conferences with efficiency and effectiveness, they should be previously we11-trained and, when 
called to this office, free from the administrative responsibilities involved in overseeing additional departments. 
Andrews University

Seventh-day Adventist Theological Seminary

A DESCRIPTION AND ANALYSIS OF THE ROLE OF THE LOCAL SEVENTH-DAY ADVENTIST CONFERENCE COMMUNICATION DIRECTOR IN THE UNITED STATES

\author{
A Project Report \\ Presented in Partial Fulfillment \\ of the Requirements for the Degree \\ Doctor of Ministry
}

by

Daryl Louis Meyers

JuTy 1981 



\title{
A DESCRIPTION AND ANALYSIS OF THE ROLE OF THE LOCAL SEVENTH-DAY ADVENTIST CONFERENCE COMMUNICATION DIRECTOR IN THE UNITED STATES
}

\author{
A dissertation presented \\ in partial fulfillment of the requirements \\ for the degree \\ Doctor of Ministry
}

by

Daryl Louis Meyers

APPROVAL BY THE COMMITTEE

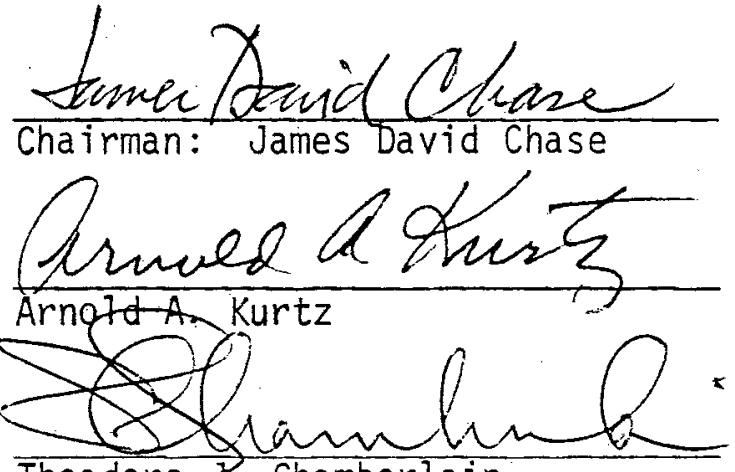

Theadorery. Chamberlain
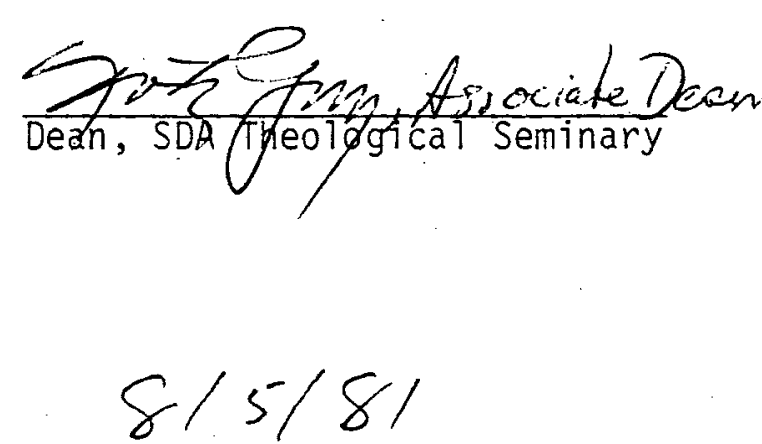

Date approved 
TABLE OF CONTENTS

LIST OF TABLES . . . . . . . . . . . . . . . . vii

LIST OF FIGURES . . . . . . . . . . . . . $x$

ACKNOWLEDGMENTS ................................ xi

Chapter

I. INTRODUCTION: AN OVERVIEW OF THE PROJECT . . . . . 1

The Objective of the Project.......... 1

Justification of the Project .......... . 1

Description of the Project .......... 2

Definition of Terms ............ 4

II. A THEOLOGICAL BASIS FOR COMMUNICATING THE GOSPEL . . . 6

Introduction .............. . . . 6

Communication Breakdown and Restoration ..... . 6

Biblical Modes of Communication ........ 8

Incarnation: The Ideal of Divine Communication . . 11

Incarnation: The Ideal of Christian

Communication ................ 13

The Church: Message and Medium ...... . . 16

Seed-sowing: Proclamation ......... 18

Watering and Growth: Persuasion and

Change through Identification ....... 21

Growth and Fruitbearing: Change

through Cultivation ........... 28

III. THE ROLE OF THE LOCAL CONFERENCE COMMUNICATION

DIRECTOR IN SEED-SOWING EVANGELISM ......... 32

Introduction . . . . . . . . . . . . . 32

Effective Communication Methods ....... . 32

Preparation for Seed-Sowing ........ . . 35

Goals for Seed-Sowing Activities . . . . . . . . . 38

Seed-Sowing Strategies .......... 39

Measurement of Seed-Sowing Effectiveness . . . . . 41

Background and Training of the Conference
Communication Director . . . . . . 43 
Chapter

IV. DESCRIPTION OF SURVEY PROCEDURES . . . . . . . 47

Introduction ................ 47

Design and Development of the

Survey Instrument . . . . . . . . . . 47

The Pre-Questionnaire ......... . . 53

Role Description for Conference

Contact with Communication Directors ....... 61

Contact with Andrews University Faculty . . . . . . 61

Description of the Population .......... 62

Rationale for Survey Questions . . . . . . . . 63

Survey Implementation .......... 68

V. RESULTS OF THE QUESTIONNAIRE . . . . . . . 77

Introduction ............. . . 77

Offices Held by Local Conference

Communication Directors . . . . . . . . . 78

Assistance Given by the Local Conference

Communication Director . . . . . . . . . 87

The Primary Place of the Local Conference

Communication Director in "Finishing"

God's Work ............. . 113

Professional or Specialized Training

Needed by Conference Communication Directors . . 128

The Relative Importance of the Work of

the Local Conference Communication Director . . . 138

Educational Background and

Training of Respondents ......... . 155

Degree of Acquaintance Pastors Have

with the Conference Communication Director . . . 176

Areas Concentrated on the Most Frequently

by Local Conference Communication Directors

During a Typical Three Month Period ... . . . 178

Areas where the Communication Director Could

Use Help, as Well as Give Needed Assistance

to Pastors and Conference Presidents . . . . . 180

Summary ............... 189

Analysis.............. 198

VI. RECOMMENDATIONS BASED ON RESEARCH FINDINGS . . . . 205

APPENDIX .............................. 273

A. Chart on the Spiritual Decision Process . . . . . 214

B. Pre-Questionnaires Sent to Fifty
Denominational Workers.......... . 216

C. General Conference Role Description for

D. List of Andrews University Faculty Consulted . . . . 224 
E. Letter Accompanying Pre-Questionnaire . . . . . . 226

F. Letters of Correspondence Regarding Questionnaire ................ 228

G. Cover Letters for Surveys . . . . . . . . . . . 231

H. Surveys . . . . . . . . . . . . . . . . . 234

I. Additional Offices or Positions Held by Conference Communication Directors other than Those Listed in the Survey . . . . . . . . . 244

3. Additional Activities Engaged in or Assistance Given by the Conference Communication Director During a One Month Period (Not Listed in the Survey as Perceived by the Respondents . . . . . . . . 246

K. Professional or Specialized Training Needed

by Conference Communication Directors as Suggested by the Additional Comments of the Respondents ... . . . . . . . . . 251

L. Additional Remarks by the Respondents Regarding Their Major Field of Study in College . . 254

M. Additional Remarks of Respondents Regarding College Major or Minor in Communication: Areas of Emphasis . . . . . . . . . . . 256

N. Post-Graduate Job-Related Training in Communication: Additional Areas... . . . . . . 258

0 . Additional Remarks Regarding the Degree of Acquaintance Pastors Have with the Local Conference Communication Director . . . . . 260

P. Additional Remarks Regarding Areas of Communication Concentrated on the Most Frequently by Conference Communication Directors During a Typical ThreeMonth Period. . . . . . . . . . . . . . .

Q. Additional Remakrs Regarding the Assistance Conference Presidents and Pastors Need From Their Conference Communication Directors . . . . . . . . . . .

R. Letter and List of Denominations From the General Conference Communication Department . . . . . . . . . . . . . . 268 Sample Letter Sent to Non-SDA Denominations . . . . 271 Correspondence from Various Denominations . . . . . 273

S. A Communication Strategy of the United Methodist Church ............ 289

T. A Communication Strategy of the
United Presbyterian Church . . . . . . . . . . 301

U. A Communication Strategy of the

V. A Study Conducted in Australia Concerning Basic Attitudes to the Seventh-day Adventist Church 
SELECTED BIBLIOGRAPHY ................ 336

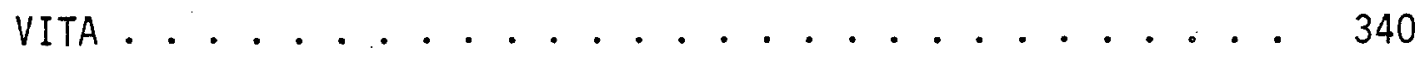


LIST OF TABLES

1. Categories of Unacceptable Responses . . . . . . 72

2. Survey Results .............. 75

3. Methods of Contacting Respondents ......... 76

4. Conference Positions Held by Conference.... .779

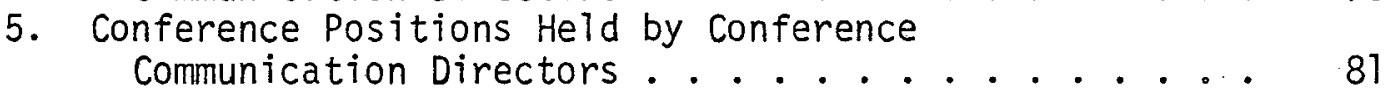

6. Conference Positions Held by Conference $\quad$ Communication Directors .... 82

7. Conference Positions Held by Conference $\ldots . . . .83$

8. Activities Engaged in or Assistance Given by the Conference Communication Director During A One Month Period as Perceived by the Following Respondents (Survey Items 18-21 and 23-25) ................ 88

9. Activities Engaged in or Assistance Given by the Conference Communication Director During A One Month Period as Perceived by the Following Respondents (Survey. Items $26,28-37,33,34) \ldots 9 . \ldots 90$

10. Activities Engaged in or Assistance Given by the Conference Communication Director During A One Month Period as Perceived by the Following Respondents (Survey I tems $35,36,38-41,43)$.............. 92

11. Activities Engaged in or Assistance Given by the Conference Communication Director During A One Month Period as Perceived by the Following Respondents (Survey Items 44-46,48-51) .............. . . 94

12. Activities Engaged in or Assistance Given by the Conference Communication Director During A One Month Period as Perceived by the Following Respondents (Survey Items $53-56,58-60) \ldots . . . . . . . . . .996$

13. Activities Engaged in or Assistance Given by the Conference Communication Director During a One Month Period as Perceived by the Following Respondents (Survey Items $61,63-65,67-69) \ldots \ldots . . . \ldots$ 
14. Activities Engaged in or Assistance Given by the Conference Communication Director During

A One Month Period as Perceived by the

Following Respondents (Survey I tems

70, 72-75)

15. Activities Engaged in or Assistance Given by

the Conference Communication Director During

A One Month Period as Perceived by Pastors

16. Activities Engaged in or Assistance Given by

the Conference Communication Director During

A One Month Period as Perceived by

Conference Communication Directors . . . . . . 106

17. Activities Engaged in or Assistance Given

by the Conference Communication Director During

A One Month Period as Perceived by

Conference Presidents . . . . . . . . . . .

18. The Primary Place of the Local Conference

Communication Director in "Finishing"

God's Work . . . . . . . . . . . . . 114

19. Pastors' Response to the Primary Place of the

Conference Communication Director in

"Finishing" God's Work

20. Conference Communication Director's Response to

the Primary Place of the Local Conference

Communication Director in "Finishing"

God's Work

21. Conference President's Response to the Primary

Place of the Local Conference Communication

Director in "Finishing" God's Work .....

22. Professional or Specialized Training Needed

by Conference Communication Directors as

Suggested by the Following Respondents

23. Professional or Specialized Training Needed

by Conference Communication Directors as.

Suggested by the Following Respondents

130

24. Professional or Specialized Training Needed

by Conference Communication Directors as

Suggested by Pastors
rofessional or Specialized Training Needed

25. Professional or Specialized Training Needed
by Conference Communication Directors as

Suggested by Conference Communication Directors . . .

26. Professional or Specialized Training Needed

by Conference Communication Directors as

Suggested by Conference Presidents

27. Relative Importance of the Work of the

Conference Communication Director

28. Pastor's Response to the Relative Importance of the Work of the Conference Communication Director

29. Conference Communication Directors' Response to the Relative. Importance of the Work of the Conference Communication Director 
30. Conference Presidents' Response to the Relative Importance of the Work of the Conference Communication Director ........ 153

31. Major Field of Study in College........... 156

32. Major Field of Study in College . . . . . . . . 157

33. Major Field of Study in College . . . . . . . . 158

34. Major Field of Study in College . . . . . . . . 160

35. College Major in Communication: Areas of Emphasis............ 162

36. College Minor in Communication: 163

37. Post-Graduate Job-Related Training in Communication ........... . 164

38. Experience in Those Fields Related to Public Relations or Communication--I . . . . . 166

39. Experience in Those Fields Related to Public Relations or Communication--II . . . . . 168

40. Experience in Those Fields Related to Public Relations or Communication--III . . . . . 169

41. Experience in Those Fields Related to Public Relations or Communication--IV . . . . . . . 170

42. Experience in Those Fields Related to Public Relations or Communication ........ . 171

43. Experience in Those Fields Related to Public Relations or Communication . . . . . . . 173

44. Experience in Those Fields Related to Public Relations or Communication . . . . . . . 175

45. Degree of Acquaintance Pastors Have with the Local Conference Communication Director . . . . . 177

46. Areas of Communication Concentrated on the Most Frequently by Conference Communication Directors During a Typical Three Month Period . . . . 179

47. What Pastors Would Like to Have Their Conference Communication Directors do for Them, Their Churches or Institutions that Would be of Most Immediate Benefit ... . . . . . . 181

48. What Conference Communication Directors Would Like Administrators, Pastors, or the Church in General to do for Them Which Would be of Most Immediate Benefit to Them or Their Departments .......... 185

49. What Conference Presidents Need Right Now that Their Conference Communication Directors Could Provide Help With . . . . . . . 187 


\section{LIST OF FIGURES}

1. Activities Engaged in or Assistance Given by the Conference Communication Director During a One Month Period as Perceived by the Following Respondents ...........

2. Activities Engaged in or Assistance Given

by the Conference Communication Director

During a One Month Period as Perceived

by the Following Respondents . . . .......

3. Activities Engaged in or Assistance Given

by the Conference Communication Director

During a One Month Period as Perceived

by the Following Respondents ..........

4. Activities Engaged in or Assistance Given

by the Conference Communication Director

During a One Month Period as Perceived

by the Following Respondents ..........

5. Activities Engaged in or Assistance Given

by the Conference Communication Director

During a One Month Period as Perceived

by the Following Respondents ..........

6. Activities Engaged in or Assistance Given

by the Conference Communication Director

During a One Month Period as Perceived

by the Following Respondents ...........

7. Activities Engaged in or Assistance Given

by the Conference Communication Director

During a One Month Period as Perceived

by the Following Respondents . . . . . . . . 101

8. Respondents' Perceptions as to the Primary

Place of the Local Conference Communi-

cation Director in "Finishing" God's Work . . . . 115

9. Respondents' Perceptions as to the Primary

Place of the Conference Communication

Director in "Finishing" God's Work........ 118

10. Respondents' Perceptions as to the Primary

Place of the Conference Communication

Director in "Finishing" God's Work . . . . . . .

11. Respondents' Perceptions as to the Primary

Place of the Conference Communication

Director in "Finishing" God's Work ........ . 122

12. Respondents' Perceptions as to the Primary

Place of the Conference Communication

Director in "Finishing" God's Work ........ 
13. Respondents' Perceptions as to the Primary Place of the Conference Communication Director in "Finishing" God's Work ........ . 125

14. Professional or Specialized Training Needed by Conference Communication Directors as Suggested by the Following Respondents . . . . . .

15. Professional or Specialized Training Needed by Conference Communication Directors as Suggested by the Following Respondents .......

16. Respondents' Perceptions as to the Relative Importance of the Work of the Conference Communication Director . . . . . . . . . . . .

17. Respondents' Perceptions as to the Relative Importance of the Work of the Conference Communication Director ............

18. Respondents' Perceptions as to the Relative Importance of the Work of the Conference Communication Director . . . . . . . . . . . .

19. Respondents' Perceptions as to the Relative Importance of the Work of the Conference Communication Director . . . . . . . . . . .

20. Respondents' Perceptions as to the Relative Importance of the Work of the Conference Communication Director . . . . . . . . . . .

spondents' Perceptions as to the Relative Importance of the Work of the Conference Communication Director ........... Communication Director 


\section{ACKNOWLEDGMENTS}

I wish to express my sincere appreciation to Eugene A. Anderson of Atlanta, Georgia, whose guidance and encouragement have greatly contributed to the success of this project.

Appreciation is also in order for my wife and family, for their moral support, encouragement, and patient endurance during the course of this research project.

Finally, I wish to express my appreciation to my D.Min. project committee: James David Chase (chairman), Arnold A. Kurtz, and Theadore J. Chamberlain for their valuable assistance in this project. 
CHAPTER I

INTRODUCTION: AN OVERVIEW OF THE PROJECT

The Objective of the Project

Through correspondence, interviews, surveys, and research into available literature, correlated with biblical principles on the project theme, the researcher sought through this project to provide the laity, church pastors, local conference communication directors, and conference presidents with a better understanding of the place for; and duties of a trained conference communication director in the evangelistic stratagem of the Seventh-day Adventist Church.

\section{Justification of the Project}

1. Although the General Conference Communication Department has a plan of action outlined for local conference communication directors, a clearly stated rationale for this department correlated with a training program for those aspiring to, or newly appointed to this post is desirable.

2. Based on the researcher's personal experience as a pastor and union communication director, there seems to be a significant lack of understanding by administrators, pastors, and laity on the evangelistic role of the local conference communication director in the mission of the church. This study seeks to clarify 
the role of this department in its inter-relationship with other local church ministries.

3. In the light of the church's emphasis on evangelism and the importance it attaches to making its teachings relevant to modern man, there is an apparent need for the development of a thoroughly researched, comprehensive, and biblically based strategy for evangelism. Such a strategy, focusing on the local conference communication director and his work among pastors and laity, forms a part of this study.

4. Since, to the knowledge of the researcher, no thorough study has been done on the place and ministry of the local conference communication director in the evangelistic program of the church, the need for an indepth study in this area is warranted. Additional encouragement has been given by the General Conference Communication Director and his associates.

5. Having done some preliminary research on this subject coupled with several years of experience on conference and union levels as an evangelist, pastor, and communication director, the researcher senses a personal need for a better understanding of the relationship between the local communication department and a pastoral-evangelistic ministry. He also senses that the outcome of a research project of this nature could be of significant benefit to the church in clarifying the role of the communication director on the local conference level.

\section{Description of the Project}

1. A theological paradigm illustrating the biblical ideal of communication, and an holistic biblical approach to evangelism 
derived from research in the Scriptures, the Spirit of Prophecy writings, and available theological literature on the subject, has served as a foundation for this study.

2. Authorities in the field of communication were consulted as to the latest findings in this area. This information was obtained through interviews, contacts with other denominations, and investigation into available literature resources on the subject. The results were then integrated into an evangelistically oriented framework centering on the work and ministry of the local conference communication director.

3. In addition to the interviews with authorities in the field of communication, a pre-questionnaire was sent to a representative group of pastors, conference communication directors, and conference presidents in order to ascertain their views on the role concepts and expectations of the work of the local conference communication director. Information received from the interviews and prequestionnaires were studied and evaluated. Based on the data obtained, and the research previously outlined, a series of three questionnaires were developed and sent to all local conference communication directors in the United States, all local conference presidents, and a random sampling of Seventh-day Adventist pastors. The information received from these questionnaires assisted the researcher in describing and analyzing the role of the local conference communication director.

4. The final recommendations chapter of this project was written after a careful evaluation and analys is of research data. 


\section{Definition of Terms}

Except where the context indicates differentiy, the following definition of terms should be considered standard for this project report:

United States. This is the country in North America made up of fifty geographical areas or states called the United States of America. All fifty states are included in this study but no U.S. territories.

Conference. A conference is an organizational unit within a division (in this case the North American Division) usually consisting of a state or geographical area often referred to as the "local conference."

Pastors. This term, as used in this project report, refers to a11 ordained and licensed pastors of the Seventh-day Adventist Church in the United States who are in charge of local church congregations.

Communication Directors. This term refers to all officers of the Seventh-day Adventist Church in the United States who have been designated by the church to carry on a program of communication on the local conference level.

Conference Presidents. This term is given to the leading administrators of the local conferences of Seventh-day Adventists in the United States.

Communication Secretaries. This group is composed of those individuals elected by the church board to carry on a program of communication for the local church.

Communication. Although there may be various technical 
differences, public relations or communications are concepts used interchangeably in this research project. They refer to the transmission of the gospel message as understood by the Seventh-day Adventist Church to church members and the world at large presented in terms which can be understood, appreciated, and on which a responsible decision can be made.

Questionnaire. The terms questionnaire or survey are used interchangeably and refer to the instrument designed and used to get the responses needed for the project under study.

Seed-sowing Evangelism. For this project report, seedsowing evangelism refers to that process of communication seen as equal to or parallel to the breaking up or cultivation of the soil and the sowing of the seed prior to the reaping of the harvest. It is not just a vehicle for evangelism but is at the very heart of the evangelistic process itself, a preparatory process of evangelism in contrast, yet in harmony, with evangelistic reaping.

Image-building Evangelism: This terminology refers to communication which stimulates or reinforces evangelism rather than communication which is evangelistic in nature. The emphasis is on the end results--the image or appearance of the church being built up through communication--rather than on function. 
CHAPTER I I

\section{A THEOLOGICAL BASIS FOR COMMUNICATING \\ THE GOSPEL}

\section{Introduction}

In this chapter an attempt is made to establish a biblical base for the work of the conference communication director in an evangelistic context by exploring certain principles of communication as appears to be revealed in the scriptures. The areas dealt with are as follows: (1) Communication breakdown and restoration; (2) Biblical modes of communication; (3) Incarnation: the ideal of divine communication; (4) Incarnation: the ideal of Christian communication; (5) The church: message and medium; (6) Seed-sowing: proclamation; (7) Watering and growth: persuasion and change through identification; and ( 8 ) Growth and fruitfulness: change through cultivation.

\section{Communication Breakdown and} Restoration

In the Garden of Eden experience, man spoke to God face to face. There was no need for an intermediary; but when sin became a part of his existence this relationship between mankind, his creator, and his neighbor became distorted and confused. ${ }^{1}$ Faith

IIsa $59: 1-2$ (RSV). 
and Tove were replaced by fear and insecurity. ${ }^{l}$ No longer could man understand his Creator or himself, for he was now alienated from God. ${ }^{2}$ His mind had become darkened. ${ }^{3}$

Not far removed from the third chapter of Genesis is the story of the Tower of Babel which aptly. illustrates the confused state of affairs that developed when mankind through disobedience was separated from God. According to the biblical narrative, not only was mankind no longer capable of communicating directly with his Maker, but he also found it difficult to understand or to be understood by his fellow man. ${ }^{4}$ Due to his fallen condition, his language, originally a sign of his nobility, became a problem full of inner contradictions. 5

Since the character and purposes of the creator were now shrouded in a mysterious darkness impregnable to the human mind in its fallen state, only one course of action could be taken. God must make a revelation of Himself to mankind in terms which he could understand, and through those means appropriate for reaching him in his fallen condition.

Concerning God's initiative in revealing Himself Hendrik Kraemer says:

Ten 3:8-13 (RSV).

2 James Montgomery Boice, God the Redeemer (Downers Grove, IL: Inter-Varsity Press, 1978), pp. 30-3T.

3 Eph $4: 18$ (RSV).

${ }^{4}$ Hendrik Kraemer, The Communication of the Christian Faith (Philadelphia, PA: The Westminister Press, 1963), p. 66.

${ }^{5}$ Ibid., p. 65. 
Revelation means that God wants to be known, not to be known about. God discloses Himself in His acts in concrete human history by opening His heart and making known the "mystery" of His saving will in order to commune with man.

\section{Biblical Modes of Communication}

Some examples of the media God chose to reveal Himself in order to bridge the communication gap brought about by sin are as follows: $:^{2}$

1. Revelation through nature. God speaks to man through His created works. "The heavens declare the glory of God; and the firmament showeth forth His handiwork. Day unto day uttereth speech, and night unto night showeth knowledge. "3

2. Revelation through the sacrificial system. Beginning with the lamb offered by Abel and continuing down through the centuries when sacrificial offerings were made in connection with the sanctuary service, God in symbolic form revealed Himself in the person of His Son as the "Lamb of God, which taketh away the sins of the world." 4

3. Revelation through the rainbow. Following the flood, God used the rainbow as a symbol of His covenant with man promising never again to destroy the world by a flood. "I set My bow in the cloud, and it shall be a sign of the covenant between Me and the earth. ${ }^{15}$

Tibid., p. 23.

2 James David Chase, "Radio Spot Evange Tism: The Development of a Research-based Radio Spot Series for Nominal and Non-Christians" (D.Min. dissertation, Andrews University, 1977), pp. 6-9.

$$
{ }^{3} \text { Ps 19:1-2. } \quad{ }^{4} \text { John 1:29. } \quad{ }^{5} \text { Gen 9:13 (RSV). }
$$


4. Revelation through the Sabbath. Having established the sabbath during creation week as the final display of His creative power, God has continued to communicate with man through the medium of time. "Moreover also I gave them My sabbaths, to be a sign between Me and them, that they might know that I am the Lord that sanctify them." 1

5. Revelation through Urim and Thummin. God communicated His will to the Children of Israel through the two precious stones found on the breastplate of Israel's High Priest. ${ }^{2}$

6. Revelation through "fiery serpents." The protection of God having been removed from the Israelites because of their complaining, they were, on one occasion, attacked by "fiery serpents." This experience eventually led them to repentance and a revelation of the One symbolized by the brass serpent set up by Moses on a pole. For "the Lord said unto Moses, Make thee a fiery serpent, and set it upon a pole: and it shall come to pass, that everyone that is bitten, when he looketh upon it, shal1 live." ${ }^{3}$

7. Revelation through angels. God has often used angels to reveal Himself and to communicate with man. "Are they not all ministering spirits sent forth to minister for them who shall be heirs of salvation?" 4

8. Revelation through dreams. God has on different occasions communicated his will to men through dreams. For instance, He spoke to Joseph, ${ }^{5}$ Pharoah, ${ }^{6}$ and King Nebuchadnezzar ${ }^{7}$ through dreams.
1Ezek. 20:12.
2 Num $27: 27$.

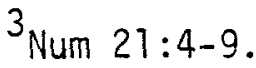
$4_{\text {Heb } 1: 14 .}$.
${ }^{5}$ Gen 37.
${ }^{6}$ Gen 41 .
${ }^{7}$ Dan 2:1-49. 
9. Revelation through a voice from heaven. Rarely has God spoken directly from heaven to mankind, but he did so on several notable occasions. He gave the ten commandments from Mount Sinai, 1 as well as communicating directly with Moses, Aaron, and Miriam together. ${ }^{2}$ He also spoke to Jesus during His ministry on earth. ${ }^{3}$

10. Revelation through the Holy Spirit. God has sent His Spirit as a medium of revelation and communication between Himself and man. 4

11. Revelation through the prophets. God has also made known His will through the prophets. "Surely the Lord God will do nothing, but He revealeth His secret unto His servants the prophets. $" 5$

12. Revelation through the Scriptures. Through the inspired writings of the 01d and New Testaments God revealed Himself to man. "Al1 Scripture is given by inspiration of God, and is profitable for doctrine, for reproof, for correction, for instruction in righteousness. "6

13. Revelation through Christ. The ultimate revelation of God to man has come through the Word that became. "flesh and dwelt among us." 7 "God, who at sundry times and in diverse manners, spoke in times past unto the fathers by the prophets, hath in these last days spoken unto us by His Son." 8

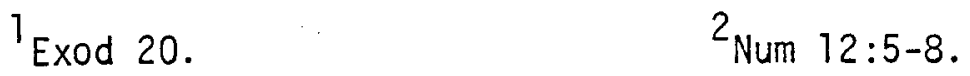

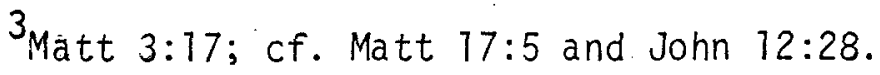

${ }^{4}$ Matt 10:19-20. ${ }^{5}$ Amos $3: 7$; cf. Num $12: 6$.

$62 \operatorname{Tim} 3: 16$. 7 John $1: 14$.

7 Heb $1: 1-2$. 
Incarnation: The Ideal of

Divine Communication

The greatest revelation of Himself and His love for mankind that God could have ever given was when He provided for His Son to step down from the throne of the universe to become Immanuel, "God with us." 1 The apostle John describes this infinite gift in the following words:

And the Word was made flesh and dwelt among us, (and we beheld His glory, the glory as of the only begotten of the Father) full of grace and truth. 2

And again he says, "No one has ever seen God; but God's onty Son, He who, is nearest to the Father's heart, He has made Him known." 3

To stress even further the immeasurable condescension of God in coming to this world in the person of His Son, John W. Carlton states:

As He stooped beneath the lowest roof in Bethlehem and clothed Himself in the garments of our frail flesh, He flashed no credentials of divinity. Rather, here was divinity divine enough to abandon divinity, majesty secure enough to proceed unmajestically, strength strong enough to become weakness, goodness good enough to become unmindful of its own reputation, and love plenteous enough to give and not take again. 4

Jesus was sent to this world to represent the Father. As the "true 1ight" ${ }^{5}$. He came to dispel the darkness of misapprehension and fear in men's minds concerning their Creator. As God Incarnate He became as it were "a window in time" through which sinful finite

$$
\begin{aligned}
& \text { 1Matt 1:23. } 2 \text { John } 1: 14 . \quad \text { John } 1: 18 \text { (NEB). } \\
& \text { 4John W. Carlton, "Proclaiming the Incarnation," Review }
\end{aligned}
$$
and Expositor 71 (Winter 1974):87.

5 John $7: 9$. 
beings might once again behold" the eternal, unchanging love of God." 1 He "came to humanity that He might reach humanity." Through Him the communication breakdown between God and man was to be restored.

Knud Jørgensen proclaims the "Good News" of Christ's

mission in these words:

Just as all men have a share in the breakdown of communication so all must have a share in the Good News about the breakthrough in communication. 3

Not only was Jesus a means of restoring communication between God and man, He was the communication between God and man. John expresses this thought most persuasively in the following verses:

That which was from the beginning, which we have heard, which we have seen with our eyes, which we have looked upon, and our hands have handled, of the Word of life: (For the life was manifested, and we have seen it, and bear witness, and show unto you that eternal life, which was with the Father, and was manifested unto us); That which we have seen and heard declare we unto you, that ye also may have fellowship with us: and truly our fellowship is with the Father, and with His Son Jesus Christ." 4

In speaking of the Christ event, C. H. Kraft not only emphasizes the breakthrough in communication through the Incarnation but also the risk involved in God becoming man:

What a terrible risk Jesus took in . . . making Himself vulnerable, able to be talked back to, able to be criticized by men, able to be tempted. But in this process of rejecting

TWilliam Barclay, The Gospel of John (Edinburgh, Scotland: The Saint Andrew Press, 1956), p. 15.

${ }^{2}$ Ellen G. White, The Acts of the Apostles (Mountain View, CA: Pacific Press Pub. Assn., 1917), p. 134.

3 Knud Jørgensen, "Models of Communication in the New Testament," Missiology 4 (October 1976): 472 .

${ }^{4} 1$ John $1: 1-3$ (RSV). 
the assigned status that He had a right to retain, He put Himself in the position to win (rather than demand--as He had a right to) our respect, to earn (rather than simply to assume) our admiration and allegiance on the basis of what he did and became among us. In the process, man discovered that God was even more impressive than His doctrine had told him He was. This discovery was doubly meaningful because it was based not simply on knowledge about God but on experience with Him. ${ }^{1}$

So into a world shattered by $\sin$, God sent His only begotten Son, the Word made flesh, that through Him the lost relationship of Eden might be restored. "For unto us a child is born, unto us a son is given: and the government shall be upon His shoulder: and His name shall be called Wonderful, Counseller, The Mighty God, the Everlasting Father, The Prince of Peace." 2

$$
\frac{\text { Incarnation: The Ideal of }}{\text { Christian Communication }}
$$

As the divine and human were combined in the life and ministry of Jesus Christ, so must it be with Christ's followers. The Word must become flesh in us if our Christian witness is to be taken seriously. To be intellectually conversant with the various elements of the Christian faith may impress the non-believer, but it will seldom move him towards a conversion experience. Only those who come from the presence of Christ are qualified to lead others into His presence. ${ }^{3}$ Only those who have been moved by the Spirit of Jesus can bring others into fellowship with His

${ }^{1}$ C. H. Kraft, "God's Model for Cross-cultural Communication-The Incarnation," Evangelical Missions Quarterly 9 (Summer 1973): 209-21.

2 Isa $9: 6$.

3 William Barclay, Fishers of Men (Philadelphia: Westminster Press, 1966), p. 20. 
Spirit. ' Only on the basis of our re-creation, our coming into right relationship to God can there be true communion with others. ${ }^{2}$

Ellen G. White expressed this thought in the following words:

The teacher of sacred truth can impart only that which he himself knows by experience. 'The sower sows his seed.' Christ taught the truth because He was the truth. His own thought, His character, His life-experience, were embodied in His teaching. So with His servants: those who would teach the word are to make it their own by a personal experience. 3

The faithful followers of Christ do more than speak to others ${ }^{4}$ about their Christian experience. Their lives are as it were an "extension of the incarnation. " 5 Through the power of the Holy Spirit they are enabled to live, to love, and to witness to the Good News of salvation through Christ Jesus.

In referring to the power of the Spirit in the lives of Christ's followers, David W. Augsburger says:

A Christian presence energized by the Holy Spirit, is a Christian power. Not power over others---that is coercive power, dominating power. It is power to become adequate for life's difficult situation. Power to love where hate seems the only normal response. Power to forgive when resentment and retaliation seem the responsible thing. Power to endure when the suffering seems beyond the threshold of patience. 6

'C. E. Autrey, Basic Evangel ism (Grand Rapids: Zondervan Pub. House, 1959), p. 33 .

2 Kraemer; p. 19.

${ }^{3}$ Ellen G. White, Christ's Object Lessons (Washington, D.C.: Review and Herald Pub. Assn., 1947), p. 43.

${ }^{4}$ David W. Augsburger, Communicating Good News (Newton, Kansas: Faith and Life Press, 1972), p. 71.

${ }^{5}$ G. Aiken Taylor, "What Shall we Communicate?" Christianity Today 3 (May 25, 1959):15-16.

${ }^{6}$ Augsburger, p. 106. 
Furthermore, he suggests that if we are

willing to be present with the Holy Spirit in the common affairs of men, to be obedient to Him in service to the common needs of men, He releases an uncommon power within us. It is a power to communicate.?

And not only. is the Holy Spirit the power of communication, He is also the "current of communication. He is the invisible gobetween God that makes us aware, and sensitive, and open to others--as Jesus was. "2

The vehicle or principle by which the Spirit of God operates in us and through us to others is the great power of love. "God is a lover, and He intends His creatures to be lovers. He loves us into salvation. He loves evil into transformation. He loves death into birth." ${ }^{3}$ And through this love relationship we become instruments in God's hands to effect similar life changes in others; for "herein is love, not that we loved God but that He loved us, and sent His Son to be the propitiation for our sins. Beloved, if God so loved us, we ought also to love one another. "4 And this love which is "shed abroad in our hearts 15 through the agency of God's Spirit needs no justification. It always "expresses itself in service wherever it sees need. 16

David W. Augsburger says:

' Augsburger, p. $106 . \quad 2$ Jørgensen, pp. 481-482.

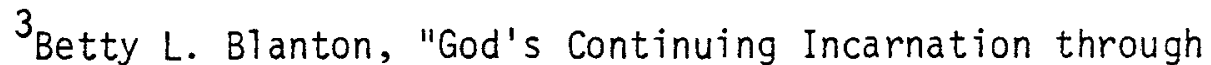
Us," Lexington Theological Quarterly 10 (April 1975):30.

${ }^{4} 1$ John $4: 10-11$ Rom $5: 5$.

6 John R. W. Stott, Christian Mission in the Modern World (Downers Grove, IL: Inter-Varsity Press, 1975), p. 30. 
Loving others, in the Jesus-way, is extending the liberating quality of deep hearing to the other person. It is giving him or her the gift of a loving, open, understanding human ear. That is when you give him or her the ear to your soul. Listening with "soul" is listening to the whole person. To the words, the feeling tones, the thoughts he cannot quite express, to the conscious or the unconscious meanings that keep coming through, to the deep human cry that is reaching out to you, the silent scream that may be buried and unknown... . To love another in the Jesus-way, is to care for another. . . . Where the other person feels pain or passion, we experience common-passion or compassion. 1

This example of Jesus in serving and identifying himself with mankind is the pattern of mission service to be followed by his church today.

The Church: Message and Medium

"Then said Jesus to them again, Peace be unto you: as My Father hath sent Me, even so send I you." 2

In the life and ministry of Jesus we have the perfect model of service. Even though the admiration and worship of the entire universe was His, because of His love for a lost world Jesus stepped down from His throne in heaven to a manger in Bethlehem. Here in a world lost through sin He clothed Himself in our nature so that once again He might communicate with us face-to-face, ministering to our needs and eventually offering Himself as a sacrifice on our behalf. He became, as it were, God's message to mankind and the medium of our salvation. ${ }^{3}$

R. W. Stott pictures Christ's condescension and ministry for mankind in the following words:

In order to serve He was sent into the world. He did not touch down like a visitor from outer space, or arrive like an

l'Augsburger, pp. 67, 70. $\quad{ }^{2}$ John 20:21. $\quad{ }^{3}$ Phil 2:5-8. 
alien bringing His own alien culture with Him. He took to Himself our humanity, our flesh and blood, our culture. He actually became one of us and experienced our frailty, our suffering and our temptations. He even bore our sin and died our death. And now He sends us into the world, to identify with others as He identified with us (though without losing our Christian identity), to become vulnerable as He did.l

Not only as individuals but corporately as members of the body of christ, we are to minister to each other and to others outside our communion as the Father through Jesus has ministered unto us. This is our mission. We receive in order to give. ${ }^{2}$ As the church identifies with God, with itself, and with others, it becomes as it were "a communications center of salvation. "3 0 out from this center go living witnesses who, themselves having been transformed by the power of the gospel, are enabled to bring others into the community of believers through a personal sharing of the good news of salvation. When viewed in this light the church, as seen through the eyes of believers and unbelievers, like its Saviour becomes both message and medium. Not only is it the channel for the good news, it is in itself the message of the good news. If for whatever reason the church "is not alive and vital, all the exhortation in the world will not generate effective outreach." If the health of the church is not taken seriously, "the cause of world evangelization is futile." 4

David J. Hesselgrave suggests this same thought in the following words:
${ }^{1}$ Stott, p. 25.
${ }^{2} \cot 2: 6$

${ }^{3}$ Malcolm Boyd, Crisis in Communication (New York: Doubleday and Co., 1957), p. 21.

4 James F. Engel, Contemporary Christian Communication

(B. T. Nelson, 1979), p. 27. 
Mission. . begins with communication and identification with God made possible because He has identified and communicated with us. Apart from this vertical relationship resulting from His incarnation and self-disclosure, and the proper response of repentance and faith on our part, there can be no mission.?

Through the parable of the sower ${ }^{2}$ jesus broadens and enriches our understanding of evangelism. In his ministry Jesus dealt "with the whole being, and with the whole period of existance possible to man." His evangelistic concern centered on the "harmonious development of the physical, the mental, and the spiritual powers." ${ }^{3}$ He looked at men not as they were but as they might become "transfigured by His grace. "4

\section{Seed-sowing: Proclamation}

One of the areas of evangelism seen in the ministry of Jesus but often neglected or considered of minor importance in the evangelistic outreach of the church is that of seed-sowing evangelism. Many if not most of the church's membership tend to overemphasize the reaping aspect of evangelism in contrast with seedsowing. However, the biblical view seems to reverse this emphasis, stressing the importance of seed-sowing as a vital prerequisite to the reaping of a good harvest. "He which soweth sparingly shall reap also sparingly; and he which soweth bountifully shall reap a) so bountifully. 15

'David J. Hesselgrave, "Identification-Key to Effective Communication," Evangelical Missions Quarterly 9 (Summer, 1973): 218.

2 Matt 13:3-23.

3 Ellen G. White, Education (Mountain View, CA: Pacific Press Pub. Assn., 1903), p. 13.

$$
{ }^{4} \text { Ibid., p. } 80 . \quad{ }_{2} \text { cor } 9: 6 \text {. }
$$


To evangelize from a New Testament perspective does not mean primarily to win converts, as it usually does when we use the word. Evangelism is the announcement of the good news about Jesus irrespective of results ${ }^{1}$ or of the methods used to bring about results. ${ }^{2}$ The biblical emphasis is on proclamation. The sower's responsibility was to sow the seed, to scatter it in ail directions, 3 to proclaim the good news of salvation ${ }^{4}$ leaving the final results in God's hands. 5 Emphasizing the proclamation aspect of evangelism, John R. W. Stott says:

Evangelism . . . is sharing the good news with others. The good news is Jesus. And the good news about Jesus which we announce is that He died for our sins and was raised from death, and that in consequence He reigns as Lord and Saviour at God's right hand, and has authority both to command repentance, faith, and to bestow forgiveness of sins and the gift of the Spirit on all those who repent, believe and are baptized. 6

The goal of proclamation--seed-sowing evangelism--is not to call for decision but to move people toward decision. ${ }^{7}$ In order to reach this goal the sower, by proclaiming the Word, helps create a climate through which the Spirit of God can operate on the heart, causing the seed to grow and mature in preparation for the harvest. Beyond the creation of this atmosphere man can do nothing. 8 Ellen G. White expresses a similar thought in the following words:

Tstott, p. 38 . ${ }^{2}$ Ibid., p. 40.

${ }^{3}$ Chase, pp. 29-30.

${ }^{4} 1$ cor $1: 23,24$; cf. John 14:5-9.

${ }^{5}$ Mark 4:26-28. ${ }^{6}$ Stott, pp. $54-55$.

7 James F. Engel and Norton, H. Wilbert, What's Gone Wrong with the Harvest (Grand Rapids: Zondervan Pub. House, 1975), p. 93. 8 Ibid., p. 52. 
The seed has in itself a germinating principle, a principle that God Himself has implanted; yet if left to itself the seed would have no power to spring up. Man has his part to act in promoting the growth of the grain; but there is a point beyond which he can accomplish nothing. He must depend upon one who has connected the sowing and the reaping by wonderful links of His own omnipotent power. 1

As an evangelist Jesus was very successful, but according to the biblical records, he experienced very little reaping during his earthly ministry. ${ }^{2}$ His success initially was in evangelistic proclamation rather than harvesting. The reaping, at least in part, came later at Pentecost after his ascension. ${ }^{3}$

With regards to the germination of the seed and its growth leading to the harvest, Ellen $G$. White gives this insight:

For a time the good seed may lie unnoticed in the heart, giving no evidence that it has taken root; but afterward, as the Spirit of God breathes on the soul, the hidden seed springs up, and at last brings forth fruit. In our lifework we know not which shall prosper this or that. This question is not for us to settle. "In the morning sow thy seed, and in the evening withhold not thy hand." 4

Even though through proclamation there may be no immediate tangible results such as decisions made leading to baptisms, some results can be detected in terms of shifts in awareness and attitude. ${ }^{5}$ In correctly evaluating the success or failure of seedsowing methods, James $D$. Chase says:

Seed-sowing should be evaluated on the extent and quality of the seed-sowing--not on the basis of how many plants have

White, Education, p. 104.

${ }^{2}$ Ellen G. White, Evangelism (Washington, D.C.: Review and Herald Pub. Assn., 1946), p. 300.

3 White, The Acts of the Apostles, p. 45.

${ }^{4}$ White, Education, p. 105.

${ }^{5}$ Engel, What's Gone Wrong with the Harvest, p. 58. 
been harvested. The two operations, while purposefully related (one sows in order to reap), are distinct in nature. 1

Only after the church has fulfilled its mission in seedsowing evangelism is it ready to take the next step of watering and growth.

\section{Watering and Growth: Persuasion and Change through Identification}

When Jesus, the Father's ultimate and final revelation of himself to man, left heaven to begin His pilgrimage on earth, he not only "traversed the infinite distance between heaven and earth to get close to us, he also covered those last couple of feet that separate person from person" in order to identify with us in our human condition. ${ }^{2}$ Rather than the God above us, he became Immanuel, "God with us." ${ }^{3}$ Made in the likeness of human flesh Jesus became "a man of sorrows and acquainted with grief." 4 He came not to condemn, however, but to save. 5 "It is not those," He said, "who are well who need a physician, but those who are sick. I have not come to call righteous men, but sinners to repentance. "6

Looking upon men in their suffering and degradation, Christ perceived ground for hope where appeared only despair and ruin. Wherever there existed a sense of need, there He saw opportunity for uplifting. Souls tempted, defeated, feeling themselves lost, ready to perish, He met, not with denunciation, but with blessing. 7

Jesus was successful in His ministry to the multitudes

${ }^{1}$ Chase, pp. 27-28.

3 Matt $1: 23$.

5 John $3: 17$.

7 White, Education, p. 79.
2 Kraft, p. 214.

${ }^{4}$ Isa $53: 3$.

6uke 5:30-32. 
simply because His hands and heart were open to their needs. In Him the people saw a friend of sinners, One who identified with them and had compassion on them, ${ }^{\top}$ One who could understand them and in whom they could safely trust. And who were

His first friends? Little people. The poor. The castoffs, the dropouts, the rejects of society! He was like that. "A friend of sinners," not of "saints." And the sinners loved $\mathrm{Him}$, followed Him, and from them He chose His disciples. . . Strange, is it not? The sick, the sad, the failures, the nogoods adore Him. And the good people can't stand Him.?

In describing Jesus' close relationship with people and His ability through an understanding of their needs to work for them positively, David W. Augsburger says:

He was gentle with those who were weak, tender with those who grow slowly, patient where understanding and action were late in coming. He would plant the seed and wait long for life to spring up. He could satisfy the request, "Lord, that I might receive my sight" and wait for the second question, "Who art thou Lord?" He was careful to respect the freedom of each person to choose or refuse. He did not threaten, force or coerce. He honored the dignity of each person and personality. And yet, to the man at the threshold of decision, He could state the alternatives with striking clarity and uncompromising honesty. He could demand the best of a man of action, incisively, unhesitatingly. And to those who had hardened themselves against the truth, he could be embarrassingly, sharply, scathingly honest. 3

Whether His discourses were given in the synagogue, on the hillside or by the lake, Jesus always impressed his listeners with the dominant influence of his teachings on life. To him religion was "not an isolated part of 1 ife" but was an influence enriching all areas of 1 ife. 4

TMatt $9: 36 ; 14: 14 ; 18: 27$; cf. Mark 6:34.

${ }^{2}$ Augsburger, pp. 64-65. 3 Ibid., p. 65.

4 Boyd, p. 20. 
In communicating the good news of salvation to the multitudes today the church's ministry must be patterned after the example of its Saviour if it expects any measure of success. As Jesus walked and talked with the people of his day, thoroughly identifying himself and his interests with theirs in order to bring them into a saving relationship to himself, so we must do today. Rather than shouting. "the gospel at people from a distance," 1 as is so often done, we must come close to them, making the gospel understandable and relevant to their needs. As Paul expresses it, "Whatever a person is like, I try to find common ground with him so that he will let me tell him about Christ and let christ save him. "2

The crowds that surrounded Jesus were not just faceless multitudes listening to a religious discourse. He saw them each as individuals, each with a different personality, and each with specific needs to be ministered to. And it was in his giving of individual attention to young and old alike that Jesus gained his greatest following as an evangelist. Much of his success was due to his interest in the perceived or felt needs of his followers. He would deal with the areas where people thought they needed help before moving on to the deeper spiritual issues needing to be dealt with. Often he ministered to the physical or emotional needs of people before inviting them to become members of his kingdom of grace. Once he told a story about a man who fell among thieves and was robbed and beaten and left half dead. ${ }^{3}$ The man's greatest need

$1_{\text {Stott, p. } 25 .}$

2Enge1, Contemporary Christian Communication, p. 26.

3 Luke 10:30-37. 
was to be born again, but his most immediate need was for some first aid. "0il and bandages for his wounds" were more important at the time than "evangelistic tracts in his pockets." 1

To the deaf, dumb, blind, and crippled; to the poor, naked, and hungry, Jesus was the divine healer and provider before he was recognized as the divine Saviour. He was the friend of sinners before he was seen as the "Lamb of God which taketh away the sin of the world." 2

In our ministry today our understanding of the basic drives and needs of people and our ability to provide them with individual support is a necessity if we would see the seeds of the gospel grow and mature as they should. Emphasizing this point through an illustration from nature, another writer explains:

No one can succeed in agriculture or gardening without attention to the laws involved. The special needs of every variety of plant must be studied. Different varieties require different soil and cultivation, and compliance with the laws governing each is the condition of success. 3

Coupled with Jesus' understanding of his audience was his ability to adapt his message to the real life situations that people found themselves in without compromising God's Word. ${ }^{4}$ He "never communicated an abstract message" but, knowing the circumstance of each individual, he focused the Word of God on their point of need. 5

'stott, p. 28.

3 White, Education, p. 112.

${ }^{4}$ Engel, What's Gone Wrong with the Harvest, p. 35.

5 Ibid., p. 39. 
In his discourses Jesus communicated with his listeners in the vernacular using illustrations and language they could understand. He avoided the religious terms, cliches, and "tired Rabbinic phrases of the Pharisees, choosing rather the language of the street, the field, the seaside, the kitchen, or the carpenter shop. His translation of truth into the common experiences of life has never been equaled." 1 Taking up this same thought, C. H. Kraft says:

Jesus. . presented His message in a highly, nongeneralized... non-theological form. The message was both lived and illustrated in very specifically life-related fashion. Jesus seldom used Scripture texts as His starting point. He chose to base His communication on the life and interests of His hearers rather than on statements of the theological principles that may be derived from His teachings. ${ }^{2}$

Perhaps the most important factor underlying the power of Jesus' words was the power of His life:

What He taught, He lived. "I have given you an example," He said to His disciples; "that ye do as I have done." "I have kept My Father's commandments." . . . Thus in His life Christ's words had perfect illustration and support. And more than this; what He taught, He was. His words were the expression, not only of His own life experience, but of His own character. Not only did He teach the truth, He was the truth. It was this that gave His teaching power. 3

As Christ's body of representatives today, the church must, like its Master, minister through word and example to the needs of humanity "in the language of humanity." 4 . It must speak "to the

'Augsburger, p. 34.

${ }^{2}$ C. H. Kraft, "The Incarnation, Cross-cultural Communication, and Communication Theory," Evangelical Missions Quarterly 9 (Fall, 1973):283.

3 White, Education, pp. 78-79.

${ }^{4}$ Ellen G. White, The Story of Prophets and Kings (Mountain View, CA: Pacific Press Pub. Assn., 1943), p. 700. 
needs of each generation" 1 in a language that can be transiated into contemporary terms; otherwise "the world will not listen, and even though it should it will not understand. "2 Enlarging on this point, James $F$. Engel says:

Nothing can be more dull and meaningless than doctrine presented at the fourteenth level of abstraction. . . Biblical doctrine is foundational for growth, but its meaning emerges when it is focused in such a way that it is relevant to Christian experience. Growth in intellectual understanding does not signify maturity in and of itself; maturity comes when this doctrine is applied and utilized in day-to-day living. 3

Unfortunately, the churches in the United States are generally "looked down upon by the majority." The reason for this is that the church just does not seem "to offer a viable option for life. Our words are tainted by a lack of credibility." 4 Sydney Cave says:

There was a time when men rejected Christianity because they disbelieved in miracles or in the Divinity of Christ. In our age a commoner cause is this: what they understand by Christianity has been disproved by their experience of 7 ife. 5

The results of a survey of young people in the United States concerning their views of the church, conducted by George Gallup and Evan Hill, seems to support Sydney Cave's thoughts. The survey responses indicate that young people's

- . most frequent complaints are that the church fails to explain itself and its precepts, that it fails to stress its

$1_{\text {Maxwe } 11 \text { V. Perrow, Effective Christian Communication }}$ (Richmond, VA: John Knox Press, 1969), p. 5.

2 Perrow, p. 35.

3 Enge 1, What's Gone Wrong with the Harvest, p. 108.

4 Engel, Contemporary Christian Communications, p. 128.

$5_{\text {Boyd, pp. 76-77. }}$ 
true meaning fervently enough, that it is not reaching the people, and that sermons are too vague and muddy. Many charge that "the church is not keeping pace with the changing world" and express disgust with what they call "too much ritual and mysticism. 1

Even though Jesus used a variety of approaches in his work, the power of his example, his identification with those for whom he ministered, and his use of the vernacular in making his messages understandable were all means to an end. He longed "to bring about change, " ${ }^{2}$ not a forced change but a change of life based on the irresistible persuasion of infinite love. Nor did Jesus expect an immediate change. He started where the people were and moved them gradually to where he felt they should be, but always within the context of "their existing needs, values, and lifestyles." ${ }^{3}$ Like our great example, "the intent of Christian communication is to bring about change." 4

However, if it is to have the life-changing influence on society that it should, the church must take more seriously its communication of the gospel. It must become "more aware of the message that it is actually communicating . . and not be misled by what it thinks it is communicating. " 5 . It must also take into account not only the conversion of the sinner but also his growth in grace.

TPerrow, p. 5.

${ }^{2}$ Engel, What's Gone Wrong with the Harvest, p. 38.

$3_{\text {Ibid. , p. } 28 .} 4$ Ibid., p. 56.

5 Perrow, p. 5. 
Growth and Fruitbearing: Change

through Cultivation

The methods used in cooperation with the Holy Spirit to bring about the initial rebirth experience must be continued in a process of cultivation, whereby the new convert has the opportunity to "grow in grace, and in the knowledge of our Lord and Saviour Jesus Christ."."

C. E. Autrey expresses this thought as follows:

The evangelism that stops with saving the soul and does not go on to build Christian character is inadequate. . . . Evangelism's chief problem is to hold its converts and enl ist them in the total ministry of the church. . . . A thorough spiritual diet of doctrinal instruction can grow bones and muscles of Christian character. All other efforts to enlist and conserve evangelistic results will fail if this basic truth is ignored.?

Further emphasizing his point Autrey says:

True evangelism, whether it is in the form of revival or perennial comphasis, will look to the welfare of the evangelized and not necessarily to the names of the evangelists. It will enlist the converted into the total ministry of the church.

An excel lent test of evangelism is seen in its permanence. What happens several months after the method has been applied? Does church attendance increase? . . . Is there a noticeable increase in power in the church, and does the church enjoy a period of permanent growth? Or do things remain as before. 3

Even though "permanent growth" should be a sign of a successful church's evangelistic program it is not spontaneous growth. It often comes about through severe conflict and at apparent failure. Each step is a struggle but under the guidance of the Holy Spirit and the Spirit-led leadership of the church, the Christian believer experiences a gradual growth in his relationship to God:

12 Pet $3: 18$.

${ }^{2}$ Autrey, p. 18.

3 Ibid. , p. 28. 
Through conflict the spiritual life is strengthened. Trials well borne will develop stedfastness of character and precious spiritual graces. The perfect fruit of faith, meekness, and love often matures best amid storm clouds and darkness. \{

Continuing along this same line of thought, Engel notes:

The Spirit functions to bring about problem recognition throughout one's life--a recognition that "what is" falls short of "what ought to be." In this sense, failure is a perfectly normal part of growth. . . Victory comes by seeking biblical principles and applying them to our lives through faith.

The key to growth and fruitfulness in the life of the Christian comes in the struggle to apply biblical teaching to the problems of everyday life. 2

Augsburger also emphasizes this thought by the following

\section{illustration:}

As a boy I made an incubator of an old box and a hundredwatt bulb. A half dozen chicken eggs were placed inside and rotated under the gentle warmth twice a day. After a dozen days, my curiosity was uncontrollable. I broke an egg to see if there was progress. There was, but the life was soon snuffed out. Sixteen, seventeen, nincteen days passed. The time for hatching came close. I couldn't wait. At the first sign of life breaking through, I had to help. I flaked away the shell in eager helpfulness. Only to be bitterly disappointed. No matter how well intentioned my efforts the chicks died. Only those who answered to their own moment of birth, who struggled through all the difficulties of breaking out, came to life.

The Christian task is not to give help, but to give love. The work is not to attack the egg with hammer and pliers but to gently warm it. ${ }^{3}$

As pastors and laity work together in an atmosphere of love, ever sensitive to each other's needs and especially those of new believers, the growth process of church evangelism will continue. However, the growth rate will not be what it should if the church

\footnotetext{
'White, Christ's Object Lessons, p. 61.

2Enge 1, What's Gone Wrong with the Harvest, pp. 54, 112. ${ }^{3}$ Augsburger, pp. 72-73.
} 
misjudges as to what really contributes to success or failure in evangelism.

What appears to be one of the greatest weaknesses of the church today is its apparent inability to grasp the meaning of evangelism in its broadest sense. Related to this problem is its general failure to properly appraise the various church programs of evange 1 ism.

Generally the norm accepted by the church as to $i$ ts success or failure in its evangelistic endeavors centers around the numbers added to the church's roster. There is nothing wrong with numbers, but to make numbers the norm for an evaluation of the effectiveness of the church's evangelistic program is biblicaliy unsound:

If we want to be biblically accurate we must insist that the essence of evangelism lies in the faithful proclamation of the gospel. It is with a view to persuasion indeed. We are not indifferent to results. We long for people to be converted. But it is still evangelism whether in fact men are persuaded to embrace it or not.

Whatever stimulates movement in the life of the individual, leading him towards a conversion experience, constitutes a "vital aspect of successful evangelism, even if it does not culminate" in a final decision. ${ }^{2}$ It should also be remembered that the Lord's standard of success is much more accurate than man's "for the Lord seeth not as man seeth; for man looketh on the outward appearance, but the Lord looketh on the heart." ${ }^{3}$ As Autrey suggests:

A healthy New Testament evangelism will add great numbers

${ }^{1}$ Stott, p. 40 .

2 Enge 1, What's Gone Wrong with the Harvest, p. 48.

3. Sam 16:7: 
to our churches. But the goal of the evangelism of Jesus is the conversion of the individual, and not an ever lengthening church roll. Never decry numbers if numbers represent redeemed souls, but make sure your goal is to redeem rather than to count. 1

Autrey continues his thoughts but with a note of warning:

Instead of being faithful to the great body of revealed truth, declaring the Gospel with clarity and waiting on God to give results in deepening of conviction and spiritual 1 ife which is condusive to genuine conversion, we run ahead of God and begin pulling the fruit while it is still green. We just must have numbers. They must walk the isles. We think it imperative that we have more additions than during the previous effort.?

There is also the possibility that a number of the church's programs have become "ineffective" due to a neglect of proper follow-up and evaluation. We need to continually ask God in regards to our evangelistic programs, "What would you have us learn from the past and do differently in the future as we follow you? ${ }^{3}$

Engel says:

The Lord has made it abundantly clear that His servants are to be accountable before Him for their labors. This means that we have no choice but to measure the effectiveness of our efforts and to evaluate the significance of what is learned for future planning. 4

In the foregoing pages implications for communication growing out of a study of certain biblical themes have been highlighted as a context against which to examine the work of the communication director in the Seventh-day Adventist Church. Against this background the following chapter seeks to del ineate a somewhat normative position for the role of the communication director.

'Autrey, pp. 27-28. 2Ibid., p. 27.

${ }^{3}$ Engel, Contemporary Christian Communications, p. 295.

4 Enge1, What's Gone Wrong with the Harvest, p. 100. 


\section{CHAPTER III}

THE ROLE OF THE LOCAL CONFERENCE COMMUNICATION

DIRECTOR IN SEED-SOWING EVANGELISM

\section{Introduction}

This chapter is based upon the researcher's findings in communication obtained through correspondence with other denominations, contacts with authorities in the field of communication, and research into available literature resources on the subject. Its purpose is to present some additional insights complementary to the preceding chapter concerring the role of the conference communication director in seed-sowing evangelism. Some of the responsibilities and concerns of the communication director covered are as follows: (1) effective communication methods; (2) preparation for seed-sowing; (3) goals for seed-sowing activities; (4) seed-sowing strategies; (5) measurement of seed-sowing effectiveness; and (6) background and training of the conference communication director.

\section{Effective Communication Methods}

Some 2,000 years ago Jesus commanded His disciples to go into all the world and "teach a11 nations. . ." Unfortunately the Great Commission, as this passage is titled, often deteriorates

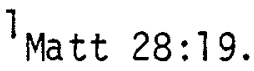


into little more than a "great commotion" when activity predominates over intelligent planning for evangelism.

Unless there are those qualified in communication guiding the church in its program of evangelization, real success is but a mirage. No matter how important the message to be conveyed or how vital the truth, if it cannot be communicated, it might as well be error.

Our remarkable organization means nothing if no one knows about it. We say we have the truth. So what? That truth must be told, or it might as well not be truth. It is as though we have this great cure for cancer and are not telling anyone about it. Yes, we meet once a week on Saturday to talk about this cure, and then we go home. Our church needs desperately to stop talking to itself and start talking to the world about Christ. 2

In line with this thought, William Bernbach, an elected member of the Advertising Hall of Fame, has stated:

I have seen too many good causes fail for want of expertness in communicating with the public and too many evil ones succeed for having it: for morality doesn't come with that expertness. That comes only with the man... There is absolutely no relationship between the worthiness of an enterprise and the communications skill expended in its behalf. Men of good will are not necessarily good communicators. And that can be a tragedy. 3

Continuing with this thought, Arthur Krock, the famed New York Times columnist wrote:

Among the anomalities of the American scene is the persistent fact that 'public relations' is an art that often is least comprehended by those who must depend on its sound practice. On numerous occasions there have been amazing demonstrations

1 James F. Engel, Contemporary Christian Communications (Nashville, TN: Thomas Nelson Inc. Publishers, 1979), p. 20.

${ }^{2}$ Tony Romeo, "Does God Need Madison Avenue?" Insight, November 22,1977, p. 5.

${ }^{3}$ Ibid., p. 6. 
that the ablest personages in industry and government fail to comprehend the simplist principles for establishing a favorable public psychology toward their activities.

Even though communication methods vary according to the time, place, and circumstances under which the gospel is presented, it is the work of the church to see that the methods used are effective in bringing about the results it desires. How to present truth so as to encourage a positive response on the part of the unconverted as well as the converted is certainly of paramount interest to the church's communication department. On the local level these concerns will occupy the attention of the conference communication director. He is the one, due to his expertise, who should guide the conference and the local church into those methods of cultivation and seed-sowing which will ultimately lead to evangelistic success. Under his guidance and through the resources available from his department, a11 conference departmental secretaries are to work together in a coordinated evangelistic thrust rather than an "everyman-for-himself" approach. Under the communication director's leadership and the Spirit's guidance, such a united front gives the church's message a broader base and a greater impact on the community, without sacrificing individuality or creativity. What is needed is "a unified strategy utilizing the strengths of the various groups in such a way that their individual distinctiveness is maintained while they make a genuine contribution to a virile, cooperative outreach." ${ }^{2}$ Without this unified ministry the message

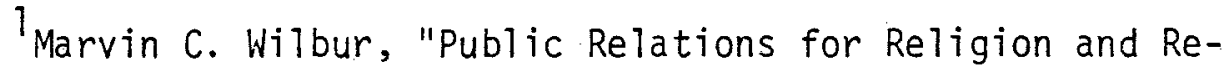
ligious Groups," in Lesiy's Public Relations Handbook, ed. Philip. Lesly (Englewood Cliffs, Nu: Prentice-Hal1 Inc., 1971), p. 239.

${ }^{2}$ EngeT, What's Gone Wrong with the Harvest? p. 80. 
of the church becomes muted. Each department tries to evangelize the world on its own and in its own way, aiming as it were little garden hoses in an attempt to put out a forest fire.

The major responsibility of the communication director through seed-sowing evangelism is to help create a climate conducive to change within the community so the church will be understood and accepted. His work centers on the proclamation of the gospel (appendix A) building up awareness through the various media and stimulating change in belief, leading eventually to a decision for Christ or the rebirth experience.

since the communication director has the responsible task of preparing the way for the church's evangelistic programs, it is extremely important that he be included on those committees or boards which determine the policies of the church related directly or indirectly to the development of these outreach programs.

Supportive of this view, Marvin C. Wilbur comments:

Since public relations is a coin with the two sides of policy and technique, it must be represented in the top policy-making groups of each religious institution. One of the greatest hindrances to effective religious public relations today is the widespread ignoring of its policy-making function. ${ }^{2}$

This is especially important as the communication director works with the various conference departments in preparation for seed-sowing activities.

\section{Preparation for Seed-Sowing}

It is the researcher's conviction that the spiritual health and vitality of the church be considered first before any evangelistic

Ibid., p. 79.

${ }^{2}$ Wilbur, p. 240. 
strategies are undertaken. ${ }^{1}$ Only when the community of believers have made the necessary preparation in their own lives are they prepared to have an influence on the lives of others. This, it would appear, should be a concern of the communication director. As Jesus said,

A city set on a hill cannot be hid. Nor do men light a lamp and put it under a bushel, but on a stand, and it gives light to all in the house. Let your light so shine before men, that they may see your good works and give glory to your Father who is in heaven. 2

Another important preparation for seed-sowing is to determine what it is the church wants, and whether it is willing to pay the price, in terms of money, effort, discipline, compromise, time, or in any other way needed to bring success. ${ }^{3}$

Under the communication director's guidance, the church should next study the community to be evangelized. Who is out there and what are their needs? What are the predominant ethnic and religious groups found in the community? Is the level of education low, average, or high compared to other areas? What are the special health needs of the people? Is the community composed of mostly retirees or some other age group? What are the political or social concerns of the community? In what condition are the people economically? Are they mostly blue or white collar workers?

In addition to these and other areas to be studied, the communication director must try to find out what the community

TEngel, Contemporary Christian Communications, p. 31.

2 Matt 5:14-16 (RSV).

3 James William Se11s, Seven Steps to Effective Communication (Atlanta, GA: Forum House PubTishers, 1973), p. 9. 
thinks about the church. What image does the church have in the community? Or does it have any at a11? Do they know we exist? If so, do they know who we are and what we stand for? Are their views correct or do they need to be changed? Answers to these and similar questions are vital if the church wishes to dialogue with the community in its evangelistic approach rather than carry on a monologue.

In 1973, Peter Kenny did some research for the Greater Sydney Conference of Seventh-day Adventists in Australia regarding community attitudes to Seventh-day Adventists (appendix $V$ ). The results of his study are of particular value to communication directors, even in North America. He found, for instance, that generally the public viewed all churches (al1 denominations) as "no longer relevant to modern life.. . out of touch . . In words, ritual or deed even with many of the people who attend them. ${ }^{1}$

As to specific attitudes to the Adventist Church, he says:

The majority of people are vastly ignorant about the Seventh-day Adventist Church. Basically, the Adventists are grouped with 'those odd religions,' and peoples' opinions toward them are coloured by their opinions towards all other 'odd' ones.

Adventists are thought to be a close-knit group . . . as being somewhat introverted, and perhaps out of step with the rest of the world. . . Because people know so little about them, the general feeling is, 'They tend to be a bit worthy, a bit less tolerant than other religions.'

The beliefs of the Adventist Church are thought of as a series of 'don'ts,' several of them erroneous;

'They don't smoke, they don't drink, they don't eat meat.'

'They don't eat, drink or be merry.'

'They don't believe in blood transfusions.'

'They don't have Sunday on the same day as us; they have Sunday on Saturday.'

IPeter Kenny, "A Study of Baśic Community Attitudes and the Seventh-day Adventist Church" (Prepared for: The Greater Sydney Conference of Seventh-day Adventists, 1973), p. 13. 
'They don't bel jeve in doctors.'

'The women don't wear make-up.'

'They don't cut their hair.'

'They don't vote.'

'They don't wear underclothes.'

The most common confusion occurs between the Adventists and the Jehovah's Witnesses. This is unfortunate, as the Witnesses are the most widely disliked of all religious groups.

Other things that people associate with the Adventists are anti-Catholic, health fanatics, faith healers, non-Christian and child exploiters. 'Do they believe in Christ? It sounds pretty Jewish to me.' 'They say there's only 140,000 people going to heaven.' 'They're the House of David, aren't they?']

Kenny says that the Australians who have the most positive view of Adventists are those who see the church as represented by its health food industries. "However," he says, "it must be stressed that people with even this small degree of acquaintance and positive feeling towards the Adventists are a very small minority. Most people are very confused about the church and its beliefs."

Even though the attitudes towards Adventists in Australia may differ somewhat from the church in North America, there are still similarities worthy of note, especially for communication directors involved in seed-sowing evangelism. ${ }^{2}$

\section{Goals for Seed-Sowing Activities}

After the research phase is completed, the communication director should assist the church in setting specific goals based on the information received from the demographical studies. The importance of having definite, well-defined goals cannot be over emphasized. Success in seed-sowing evangelism is usually much greater with this methodology than the too-often used "hit and miss," or "scattered" approach. In other words to put it more forcefully, 
"if you fail to plan, you plan to fail." 1

Engel expresses this same thought in the following words:

"If you don't know where you are going you will never know if you

hit it. Pure and simple this is the reason for a statement of goals." 2

Peter Wagner suggests a similar thought. He says:

Not to have goals, of course, is an extremely comfortable situation since with no goals it is impossible to fail. No one wants to fail, and many have convinced themselves that failure can be avoided by aiming at nothing. It has rarely occurred to these timid souls that while their system disallows failure, it also disallows success. 3

\section{Seed-Sowing Strategies}

The communication director should make sure that adequate funding is available before any seed-sowing strategy is designed or acted upon. If there are sufficient funds, then on the basis of the demographical study data, and the goals already established, the church should proceed in the development of a seed-sowing strategy adapted to the needs of those in the community it desires to reach. Such a strategy should be people or audience-oriented rather than program-oriented.

To aim at a specific group or groups within a given community who have factors in common and are more likely to respond positively to the church's message. will normally give better

${ }^{1}$ C. Peter Wagner, Your Church Can Grow (Chicago, IL: Moody Press, 1976), pp. 49-50.

2 Enge 1, Contemporary Christian Communications, p. 246.

3 Wagner, p. 51 Matt 13:8. 
results than to use a "blanket approach," scattering the seed in al1 directions.

Engel calls this the "fertile field principle." He says:

Seek out those who have factors in common who are likely to be receptive to the message at this point in time. Sometimes this is referred to as the ferti]e field principle--sow your seed where it is likely to grow.

An important part of seed-sowing is the way in which the church makes its voice heard through the seed-sowing strategy it has chosen. In consultation with the communication director, it should choose wisely those media (radio, television, newspapers, handbills, etc.) which will convey its message to the community in the most attractive, economical, and effective manner possible. In other words, the church should not only be heard but understood. Its message should be proclaimed with a "loud voice, ${ }^{2}$ but in words that are intelligible to the understanding and needs of those to whom they are directed. According to Marvin C. Wilbur,

Possession of truth does not guarantee understanding or acceptance. Ideas are competing on every hand. If the church and synagogue are to rema in vital forces, they must know how to interpret their messages convincingly to the community. 3

Engel makes a similar suggestion:

The gospel . . is not relevant if it is communicated as an abstraction. This requires that the messages utilized in the various media speak directly to the needs of people in areas such as marriage, occupation, and materialism. 4

In the advertisement phase of the church's seed-sowing strategy, there should be that type of advertising that again shows

${ }^{1}$ Enge 1, Contemporary Christian Communications, p. 46.

${ }^{2} \operatorname{Rev} 14: 7 . \quad 3$ Witbur, p. 239.

4Enge1, What's Gone Wrong with the Harvest? p. 92. 
the church's sensitivity to people's needs, causing them to respond. Yes, the church should advertise, but

not with the tired ideas that have seen too many programs fail. Advertise, not with grotesque illustrations of a beast, not with a giant photo of an evangelist that no one has ever heard of and could care less about. But advertise with creativity, the creativity that will make people read the ad, think about the message, and respond.?

The process of cultivation and seed-sowing often takes time. But it is time well spent. In fact it is a necessity if there is to be any harvest. Through such programs as the '5-Day Plan', 'Weight Control' clinics, 'The Three C's', various welfare projects, television and radio broadcasts, and many other churchsponsored, need-oriented programs, seed-sowing evangelism, if properly organized, can create a climate conducive to change and receptivity to the church's mission and message among those the church is trying to reach.

\section{Measurement of Seed-Sowing Effectiveness}

Al though the results may not always be apparent, it is an important duty of the communication director to see that all seedsowing activities or programs are evaluated in light of the purposes for which they were designed. As far as possible they should be measured as to their impact and effectiveness in relationship to the seed-sowing strategy and goals set up by the church. If they are accomplishing what they were designed to do, creating a climate of understanding and acceptance, then a continuation of these activities or programs are in order. If not, they should be discontinued.

\footnotetext{
$1_{\text {Romeo, p. } 6 .}$
} 
In noting some specifics in this area, Tony Romeo remarks

with emphasis:

Look friends, we as a church have sponsored such programs as Faith for Today, It is Written, and the Voice of Prophecy for. more than twenty years now, and still nobody knows who we are. Shouldn't this tell us something? We must not be afraid to pul1 programs off the air in favor of more useful ones. Sometimes we are like Sunday-keepers who are afraid to keep the Sabbath because it wasn't the way 'my grandmother did it.' Bravo for men like H. M. S. Richards, who pioneered in the area of radio some fifty years ago. Fantastic applause to men like William Fagal, who saw a vision of the power of TV, and for George Vandeman, who has a church on the various networks around the world. These men are pioneers, and thank God for them. However, we must now look at these programs and ask, Are they as effective as they can be? Should we pull one or two off the air in an effort to give more money to the most effective program? And should one or all of these programs be changed for a more effective. ministry? ${ }^{1}$

One of the best methods for evaluating the effectiveness of seed-sowing programs is to take a survey (door-to-door, through the mail, or by phone) before the program begins, and again during or immediately following the program, or both. Using this methodology, the communication director should be able to measure the extent of attitudinal changes among those in the community the church is trying to reach.

Len Biegel and Aileen Lubin give some additional thoughts on program evaluation and measurement:

The surest and most direct measure of a public service campaign's success is the count of people attending, donations collected, or services delivered. This does not cover all. cases, however, since many campaigns are of an educational or image-building nature, and their effects can be measured only as a result of many and varied efforts over a long period of time. However, you can and should measure how many people you are reaching

\section{Tony. Romeo, "Letters to Editors," Insight, January 24,} 1978, p. 22. 
with your message. Commercial advertisers do it, and so should you. 1

It should be noted, however, that communication directors must have the skills needed to measure program effectiveness and to handle the other responsibilities of their department otherwise very little of lasting value will be accomplished.

\section{Background and Training of the Conference Communication Director}

The influence and skill seen in the operational dimension of the communication department is in direct proportion to the background and training of the conference communication director. If his department is to be productive, he must be seen as a professional with skills in such areas as journalism, photography, advertising, market research, radio and television broadcasting, demographics, and other areas of communication. He must be perceived by his associates and constituents as a man qualified to effectively carry out the responsibilities of his office.

Dr. Herbert Ford of the Department of Communication of

Pacific Union College says that the denomination is

training young people to take up the work of public relations evangelism for conferences and to do it in an effective, professional way. But, alas, conferences are not taking advantage of these highly qualified young people. What is the reason that an almost totaliy untrained person is selected for this most important work while a fully trained, yet equally dedicated person is rejected? Is it because the fully trained young person is young? Is it because the fully trained person "doesn' $t$ know" the conference like the untrained person? Is it because the fully trained person might be 1,000 miles away while the untrained person is only 50 miles from the conference office? None of these counter balance the asset value of four solid

\section{TLen Biegel and Aileen Lubin, Mediability, A Guide for} Nonprofits (Washington, D.C.: Taft Products Inc., 1975), pp. 94-95. 
years of training, practical experience, and the resultant familiarity with how public relations evangelism may best help in the completion of the church's mission.?

John A. Jorgenson, Assistant Director of Press, Radio and Television for the Lutheran Church in America, shared some thoughts by letter with the researcher concerning the educational background and training of the Lutheran Church's PR/communication personnel. He says:

Each of the persons who have these (communication) responsibilities in the church have a background in the communications field: editing, broadcasting, newspaper reporting, journalism education, and is given encouragement to continue activity in the field through personal reading, involvement in conventions and professional organizations, occasional attendance at seminars, and in formal study.

The fall before each biennial convention our office conducts a workshop in the convention city to develop working relationships between the LCA's synod, PRT chairpersons, editors, churchwide agency communicators and the office for Communications staff; to improve communicating skills; to extend horizons and to stimulate creativity among those who would engage in helping the $L C A$ reach out with communications. 2

Wilmer C. Fields, Assistant to the Executive Secretary and Director of Public Relations for the Executive Committee of the Southern Baptist Convention, gave some insights to the researcher on the training of Southern Baptist communication personnel. He says:

As you would expect, the professionals working in this area come with a diversity of training and experience to their present positions. More and more these days however we are seeing young men and women who have degrees in their professions and also at least some seminary training. 3

THerbert Ford, "An Open Letter to Conference Presidents," First Monday, October 1979, p. 4.

${ }^{2}$ John A. Jorgenson to Daryl L. Meyers, 6 October 1980 , Lutheran Church in America, Office for Communications, New York.

3 Wilbur C. Fields to Daryl L. Meyers, 26 September 1980, Executive Committee, Southern Baptist Convention, Nashville, TN. 
According to a letter received from Eugene A. Schneider, Associate Director for the Office of Communication of the United Church of Christ,all of their staff from the office of Communication have special training in journalism and communication. "Many of our leaders," he says, "also have training in theology."1

Closely related to the communication director's training is the time required to carry out the responsibilities of his department. When conducted properly, the work of communication is a ful1time job and should be viewed as such both by the communication director himself and his associates.

Preparation in an era of rapidiy accelerated change requires constant training and upgrading in any discipline. This would seem to be particularly true with respect to the conference communication director as he enters the 1980s. What lies ahead for church communication personnel during this decade is anyone's guess. To be prepared, however, is vital, for

It could add up to a belligerent era, since everybody wants more but there may be less to go around. In short, it could be an era tailor-made for those whose verbal and written skills are able to communicate viewpoints and win converts to a specific course of action or a specific economic, social or political stance. It could be an era in which the public relations professional comes into his-and-her own. Not simply because public relations has become a recognized and useful profession, but because public relations skills will be needed by just about everybody who must enter the cockpit of conflicting interests.

The key to success in this cockpit will be a large dose of realism. Realism does not preclude optimism. It is not a negative attitude. It is a positive attitude because it pushes aside misconceptions and stresses what can actually be accomplished. It is an ability to. look at the facts, to judge the situation as it is, and to formulate a plan of action most likely to succeed. Here are some facts that realistic public relations people should be prepared to cope with in the 80s:

IEugene A. Schneider to Dary] L. Meyers, 3 October 1980, United Church of Christ, Office of Communication, New York. 
1. Our audience is more likely to be hostile than friendly. We will have to work harder and more effectively to convince.

2. We are going to have to place more reliance on facts than on methods. People can become suspicious of techniques, but they usually respect facts.

3. Our audiences will be more sophisticated, more questioning. We will often be dealing with a bunch of "Missourians" who say "Show Me" and mean it.

4. We will be expected to do more and produce better results with less. Budgets may be tighter. If the decade turns out to be the "economical Eighties," we will have to be more self-reliant.

5. We will be less specialized. We may have to switch quickly and effectively from one specialty to another on short notice. "That's not my field" will be less acceptable as an excuse for passing a job on to somebody else.

6. We will have to know more--about the company or organization we work for or represent. We will have to know about politics, social sciences, economics, demographics. Who knows, the p.r. practitioner of circa 1980 may go into the history books as anotier "Renaissance Man."

7. We will have to be more assertive. Instead of waiting for things to happen, we will have to make them happen. Instead of being geared to reacting, we will have to learn to take the initiative.

What's for sure in the next decade? Just two things:

- It won't be easy.

- It wan't be durt?

In the following chapters the results of the research conducted with respect to the conference communication director in the Seventhday Adventist Church will be presented. These chapters deal with a description of the procedures employed, a report on the results of the survey, and a final chapter of recommendations resultant from the study.

Tilliam Friedman, "Fail-Safe Strategy for the 80s: Why and How to Emphasize 'Positive Realism' in Public Relations Programming," Tips \& Tactics 17 (December 3, 1979):2 
CHAPTER IV

\section{DESCRIPTION OF SURVEY PROCEDURES}

\section{Introduction}

This chapter includes: (1) the methodology followed in the design and development of the survey instrument, including presurvey and pre-interview results; (2) a description of the population surveyed; (3) a rationale for survey questions; and (4) a description of the implementation of the survey itself.

\section{Design and Development of the Survey Instrument}

In order to develop a simple yet comprehensive survey instrument designed to obtain the information needed for this project study, the researcher decided on the following five avenues of approach: (1) interviews were arranged and conducted with several professional and academic experts in the field of communication; (2) a pre-questionnaire was sent out to fifty denominational workers in the United States for their reactions to the content of the questionnaire; (3) the role description for conference communication directors outlined by the General Conference of Seventh-day Adventists was first studied and then used as a basis for the survey final content selection; (4) six local conference communication directors from a wide geographical area within the United States were consulted by phone for their evaluation and input on the 
questionnaire; and, as a final step, (5) the questionnaire was sent out to thirty of the Andrews University faculty for their corrections, evaluations, and suggestions.

The interviews with the professional and academic experts in communication were quite informal. The questions asked were general in nature, concentrating on an overall view of the church's present communication system with special emphasis given to the work, responsibilities, and overall effectiveness of the local conference communication director. Following are a list of the numbered questions asked along with some of the insights shared with the researcher which were of particular value in the content formulation of the questionaire:

1. What are the Adventist church's needs today in the field of communication? Are these needs being met?

Generally speaking, church administrators have absolutely no concept of the principles of communication or of its value. They seem to feel that since the Lord has called them to a particular leadership post, such as conference president, they should be capable of handling everything that happens, and if they can't they feel as if they have failed their calling. As a result, they are very slow in calling professional people to become members of their staff. In contrast, institutional administrators demonstrate their leadership by getting the best possible people around them. They know they can't handle business, and academic, medical, and PR decisions, so they go out and find the very best professionals in those areas that they can. They have experts solve their problems. However, when a problem comes along to a conference president, he sits there and trys to solve it himself--including PR and communication. Someday the church will have to look to trained journalism professionals to do the job, and not warmed over preachers. Our administrators need to be taught the value of communication and the vital necessity of using professionals to do it. The bottom line is the gospel communicated. That is why we are here--to finish the work, but the work will not be finished, in my opinion, until we have a good communication program. 
I think Adventists have a tendency to be more message oriented than people oriented. We have a great message but we need to show that that message is relevant to people's needs. Unfortunately, because we are adept in theology we have a tendency to become comfortable in our expertise but not in our understanding of how that theology can meet the needs of real people.

When it comes to the communication director, his basic philosophy is, "How can I get my point across," rather than, "what point do the people need or want?" There's a big difference there. Am I emphasizing the source or the receiver?

A successful conference communication director should in his presentations emphasize the reception of the message and its effects rather than its aesthetics. We have a tendency to say, "If it's beautiful, pretty, good, well-packaged, it can't help but have good results." But study after study shows that that kind of thinking is really fallacious. Just because something looks nice doesn't necessarily mean that it will have great results. I'm more interested in what a message does to a person than how nicely packaged it is. A communication director for a local conference should not be so concerned with trying to get across his programs and his way of doing things in a blanket approach to a11 the churches in the conference. His approach should rather be to say, "What are the needs of the individual churches in their individual communities and how can I help facilitate their program so they can have excellent results?"

2. What is or should be the role of the conference communication director? Is his task in any way affected by the number of responsibilities or offices he holds?

Very few conferences or unions assign the communication department to a person as his primary responsibility. Under normal circumstances his role would be like any PR practitioner in relationship to management. He would advise the administration regarding the various publics with which he works. Because of his work with the different publics he would also need to be a part of the decision-making process, knowing what decisions were made, and the reasons why they were made. Unfortunately, at the present time, he is not a vital part of the decistion-making process on any level.

I think a critical area is the credibility of the communication director. From my experience, it seems that he is viewed as one who holds an unnecessary fringe job which is far more expendable than other secretarial positions in the conference. One of the reasons for this is that he has not 
been trained in the area of communication. Another reason why he doesn't have much credibility is that he is simply trying to do too many jobs at the same time. Either he doesn't do any of them well, or he concentrates on one to the neglect of the others.

3. Is the General Conference communication manual for conference communication directors adequate or do today's needs warrant some revision?

Even though it is a good start, the General Conference role description for the conference communication directors should be revised.

The General Conference role description for conference communication directors may be adequate, but given the lack of experience in communication training, we can legislate; we can put many things in writing, with little effect unless the person is motivated out of a sense of need for instruction in this area. Otherwise it is simply a former pastor with a lot of conference materials dumped on him, now becoming a communication director of the conference with more materials dumped on him from the union and the General Conference.

Our communication directors ought to emphasize both evangelism outside the church and evangelism within the church. There are many doctrinally solid Adventists who are not solid spiritually.

From your view what are the apparent weaknesses and/or strengths of the church's communication department? How can these be eliminated or strengthened?

In my opinion the time has come when the world church should appoint a vice president for communication. This would then make him a part of the decision-making process.

5. Someone has said that evangelistically, American Adventists are the most well-equipped inefficient group in the world. What are your thoughts on such a statement? 
We have tremendous potential; however, we somehow feel that we can set up a tent or open a church door and in three weeks the whole city is going to come in droves and be baptised, but it doesn't happen that way until they know who we are.

I think we are getting bogged down with a proliferation of self-made programs which keep us from the simple leadings of the Holy Spirit who needs to guide us into programs which Jesus Christ wants us to be doing.

6. Do you feel that sufficient planning and evaluation is being made of the various programs produced by or associated with the communication department?

I think the programs we have (radio and TV) are doing an adequate job. However, I do feel that there is a great weakness in the fact that we don't clearly evaluate and honestly look at these evaluations for future planning.

No. We are very good at planning, but we end up with a lot of programs that eventually outlive their usefulness. We need to ask ourselves, "Were we successful in moving a person from one attitude to another?" If so, then that is fine. If not, perhaps we should rethink our approach or program.

We also need to be sure that we are doing the work faithfully that Jesus has told us to do irrespective of the results. God never said that the whole world was going to be baptized. He said the world must know. And if the world knows, then we have fulfilled our responsibility--if we have done it as faithfully as we could.

7. Do you feel the funds made available for the various segments of the church's communication network are adequate? Does the amount designated for communications in any way reflect the church's view on the need for this department?

The lack of funds for the work of communication does to some degree reflect the psychic of administration. As an example, we thought radio was finished, but today it is a booming business. But how do people listen to their radios? Primarily, drive time is the prime time for radio. There people's attention is on a number of things. Very few people sit down and listen to a thirty-minute or fifteen-minute radio program. But do you 
know what happened recently at a VOP board meeting? Their spot department was completely el iminated because of budget. Why? They had to cut the budget somewhere, so they cut it in areas that weren't producing income.

I would say that every department is valuable and needs funds. An administrator overlooking all of the programs has to ask himself, "What, or how can I spend the money which the Lord has entrusted to me most productively?" Unfortunately, many administrators choose only to spend money on programs where they can see immediate visible results rather than show an enthusiastic willingness to allocate money for programs which are strictly seed-sowing but will in the long runyield an enormous amount of results (2 Cor 9:6). I'd say no. Generally the communication department is not receiving funds proportionate to the results that are needed; but at the same time I believe I understand why the administrators are not funding the communication department more--because their criteria is often wrong in terms of their understanding of what those funds should be doing.

\section{Considering the church's teachings on eschatology and}

soteriology, what are or should be the overall concepts, goals, or objectives of the conference communication secretary, and how do these concepts, goals, or objectives relate to or influence other departments of the church?

The communication director's function is to make other functions work. He doesn't have a program of his own. His program is the conference program which centers on all the other departments. In his dealing with the public I would say his ultimate goal should be to create an atmosphere of understanding, of acceptance, and of inquiry.

I am convinced that as a church, and communication directors are a part of the church, we have a malaise over us concerning the second coming of Christ. We talk about it but our actions deny our belief in our Lord's imminent return. If we really believed $i t$, our whole communication approach would be different. To a large degree we have lost the urgency of the second coming of Christ, with the result that even though many of the communication programs are good, they are peripheral to that which is absolutely necessary. The communication department and the education department and the temperance department should a 11 be directly evangelistically oriented because Jesus Christ is 
coming soon, rather than just to build up the work. Unfortunately we tend to become more institutionalized rather than more evangelistic.

\section{The Pre-questionnaire}

A pre-questionnaire consisting of ten open-ended questions centering on the work of the conference communication director was sent out along with a cover letter (appendix B) to fifty Adventist church workers in the United States as selected from the 1979 Adventist yearbook. Of these, twenty-eight were church pastors, ten were communication directors, and nine were conference presidents. of the fifty sent out, twenty-nine, or 58 percent, were returned. The following is a list of the survey questions and a random sampling of responses to the pre-questionnaire:

1. What in your understanding is the role of the conference communication director in the work or mission of the church?

He is the one who keeps church members and the public aware of various church activities through church periodicals and other news channels.

He handles mostly internal projects such as designing brochures and bulletin inserts, producing slide programs, sending in reports to the union paper, and holding periodic workshops or seminars for local church communication secretaries. around.

The way it is done now, it is one of the most useless jobs

He is available to help, encourage, and stimulate the local church communication secretary.

He is the one who takes pictures of all the major church events and many of the minor ones. 
The conference department of communication is just a place to kick a man upstairs and get him out of everyone's hair.

They don't really have a role. They just pass on materials from the General Conference Communication Department to the local church communication secretary.

It depends in a large degree upon his relationship with his particular conference administration. Often he is forced into different molds to correspond with administrations' emphasis or pet project.

2. What in your understanding should be the role of the conference communication director in the work of the church?

He should inform and educate the public about the church and its beliefs, practices, and service to the community in order to build positive attitudes as a prelude to evangelism.

He should involve the community in the life of the church by promoting open houses, health and religious programs, responsegenerating advertising, and other PR ventures.

He should train local church communicators to work profitably.

He should foster heal thy communication among church members, workers, and administrators in the church.

He should assist with fund raising and development.

He should study demographic trends and show how they effect our evange i istic programs.

He should be an advisor to administration, department directors, pastors, and churches in the development of PR programs, suggesting how they might be packaged to be best received.

He should be something of an "image maker" for the conference so that the organization is perceived in a realistic but favorable light. 
Communication is the "plow" that must go before the sowing of the seed to break up the ground. The communication director should direct and advise as to how this can best be accomplished.

He should be equal (in role) to the conference evangelist and much more far reaching.

He should be a resource man for the local pastor.

He should coordinate and direct the mass media-outlets of the church.

3. To what extent is the role of the conference communication director involved in the evangelistic outreach of the church on the local level?

Hardly any at all!

He deals mostly with articles about personnel, projects, buildings, etc., but he has very little to do with witness approaches through the media. He hasn't fully developed his evangelistic outreach yet.

I'm really not sure.

Zero!

None!

4. To what extent should the conference communication director be involved in the evangelistic outreach of the church on the local lever?

He should be heavily involved in training and advertising. He is the expert in meeting the public and helping the church put its best foot forward and using to its fullest extent the local mass media for evangelism. 
His should be an advisory capacity.

The communication director should be well informed on what works in various churches and be ready to assist the local church in implementing their ideas with their skills such as follows:

A. He should provide tools for community research, helping churches determine who is there; who can be reached by the church, and how best to reach them.

B. He should advise conference leaders and local churches on how to use the media effectively, how to build positive attitudes and encourage "foot traffic" in the church.

C. He should suggest ways for the church to interact with the community--fair booths, hotel-listing service, speakers' bureau, open houses, local radio programs, etc.

He must be 1 imited in most cases to training and resource functions. This should include in-office duties such as compiling appropriate materials, conducting workshops, etc., and also occasional field work with the local pastor in implementing evangelistic plans and techniques.

He should be a definite part of the conference evangelism committee.

5. What are the needs of the conference communication director?

He needs practical training by those who themselves have had experience on the local level.

A job description! What does my conference expect of me?

Clear conference goals! How can I help the conference get where it wants to go if it doesn't know where it's going? Some concrete goals and objectives other than "finish the work" are desperately needed.

He needs professional training. He should be a trained journalist. 
He needs to have the confidence of the administration who take his work seriousiy as an essential, integral part of the conference program.

He needs up-to-date equipment and sufficient funds to handle the demands of the job: an office, darkroom, recording studio, quality camera equipment, etc.

He must not be perceived as an errand boy whose main purpose is to run around taking pictures on demand.

He shouldn't be saddled with several other departments with communication considered a minor appendage.

We need more evangelism in our PR.

Most important he needs spiritual commitment.

6. Are the needs of the conference communication director being met?

The General Conference and union departments need a more practical approach to the whole subject of communication at the loca? Teve1.

I'm going to school evenings for professional growth. It's costing me $\$ 5,000$ ! I feel a strong need for more interaction with other conference communication directors.

Many administrators do not understand the proper role of the communication director and do not provide the level of support he needs to fulfill his responsibilities. However, in many places this seems to be improving.

He needs greater training and more "polish" as a professional.

No, he needs to feel more a part of the local church scene.

He needs the complete trust of and access to administration. At the moment he is very limited. 
Not yet.

Yes.

I think so.

The conference communication director lacks support from the union and General Conference departments mainly because the communication department is not appreciated by upper level administrators.

No!

7. In what way is the conference communication director meeting the needs of the local pastor?

He assists as a resource man, supplying us with materials for the various media outlets.

He provides a good story for me in the local union paper but other than that, not much help.

Not much, however, he does help some in educating and motivating the local church communication secretary.

He gives some limited counsel and training and provides some materials.

He doesn't do much for or with the local pastor.

He doesn't have time to do what needs to be done.

Except for a few announcements from the conference, and some information that is passed on from the union or General Conference, the local pastor doesn't know he exists.

8. In what way should the conference communication director be meeting the needs of the local pastor? 
He should provide suggested community approaches for evangelistic meetings: ingathering, Bible study programs and other programs of interest centering around the local church.

Most of the canned stuff they send out each month is not applicable on the local level.

He should be available when needed for heip.

He needs a much greater understanding of the needs of various sections of society. In other words, we get very little help in "market research."

He should be culturally involved with the local church in its community relations.

I can't really say, for the role and objectives of his office are not clearly defined.

He should be the pastors' expert for ideas.

He should assist and work with the pastor for his local needs rather than handing down dictums. Most department personnel have forgotten that they are assistants to the pastors rather than their directors.

9. Do you see any problems of role conflict when a conference communication director finds himself responsible for other departments in addition to his own?

Not necessarily. Some departments compliment each other.

No, not if he is knowledgeable in other fields.

No, for his department isn't all that demanding.

Yes, but small conferences have few options. 
A common problem. He often concentrates on the departments in which he has more expertise or interest. Often other departments seem more urgent and so the work of the communication department gets left on a backburner--sometimes permanently.

Often communication is just tossed in with a "main" department. When the communication department understands and fulfills its role, any conference will need one or more full time people.

Yes, but a necessity due to budgeting.

10. What are some additional areas that you feel should be explored concerning the work and ministry of the conference communication director in his relationship to the local church?

I'd like to see broader titles like "vice president for church outreach," and have associates under the vice president. It would provide a sense of teamwork, unity of purpose, etc.

The communication director should be a close advisor to administration in developing programs that will work and packaging them in such a way that they will be accepted by the field. He should have his ear to the ground and his finger on the pulse of the working force and laity to sense what is and what is not working, and why, and what their needs and attitudes are.

Most departments are essentially vertical; so is communication. But more than any other, it is also horizontal, cutting across departmental and even administrative lines.

More internal church communication needs to be developed-newsletters, exchange of ideas among pastors, etc.

We need trained journalists, not "warmed over" preachers.

The conference communication director needs to have a closer tie with medical and educational institutions, health education, and local PR people. 
He needs to have more time to work out in the field.

Very few of our communication directors have any training whatever for their department.

He should explore ways of discovering the felt needs of each community.

The communication director should be a channel through which the church's message for the community is distributed and the response and feelings of the community are communicated back to the church and its organizational decision makers. Primarily his responsibility is to help create a receptive atmosphere in the community for the SDA message, and secondarily, to aid in the effective communication of that message to the community.

Role Description for Conference Communication Directors

As previously mentioned, the role description for the department of communication on the local level (appendix $C$ ) was acquired from the General Conference of Seventh-day Adventists, providing the researcher additional material for the context development of the questionnaire.

\section{Contact with Communication Directors}

Just before the design and content of the questionnaire was finalized, six conference communication directors were contacted by phone for their insights and evaluation of the survey instrument. These directors were from a wide geographical area which included Pennsylvania, Michigan, California, Georgia, Iowa, and Louisiana.

Contact with Andrews University Faculty

In addition, a preliminary draft of the questionnaire was sent to thirty Andrews University faculty members seeking their 
thoughts and suggestions (see appendix D). Twenty-two of these faculty members responded. Their comments and constructive criticism were carefully considered,for a further refinement of the survey ins trument.

\section{Description of the Population}

As a result of the steps taken in developing the survey instrument, what started out as one questionnaire ended up as three: one designed for conference communication directors, another for conference presidents, and a third for ministers. However, except for slight variations where specific information was needed by certain groups of respondents, all three questionnaires (appendix $\mathrm{H}$ ) are essentially identical in design and content and are therefore considered for purposes of this study as one questionnaire.

Al though some adjustments regarding the number of respondents surveyed were found necessary during the survey implementation stages, the total population to which the project was addressed at the beginning of this project numbered 4,452. ${ }^{1}$ From this number a target group of 452 was selected in the following manner:

1. At present there are 53 conference or mission presidents in the United States; however, five of these also hold the office of communication simultaneously with their responsibilities for the presidency. Since the main thrust of this project centers on a role description of the conference communication director, it was decided to eliminate the names of these five as conference presidents

${ }^{1}$ Seventh-day Adventist Yearbook (Washington, D.C.: Review and Herald Pub. Assn., 1980), pp. 38-106, 585-836. 
and consider them only as communication directors. Thus, the total number of conference presidents surveyed was reduced from fiftythree to forty-eight. 1

2. Even though the denomination has fifty-three confereences or missions in the United States, only forty-nine out of the fifty-three have communication or PR directors. However, since one of the conferences has two workers in communication the total number of communication directors surveyed came to fifty. ${ }^{2}$

3. The total number of denominationally ordained and licensed ministers in the United States is $4,349 .^{3}$ In order to get a statistically recognized random sampling of this group, the researcher used the 95 percent confidence ratio which gave the number 354 as the random sampling size needed to be statistically accurate for a pastoral population of 4,349. All 354 of these were surveyed including an additional ninety sent as extras in case some of the 354 failed to respond. Thus, the total number of pastoral respondents surveyed was 444 .

\section{Rationale for Survey Questions}

As already indicated, the final draft of the survey used for its design and content at least five different sources. In as short a time period and simple a manner as possible each section of the survey and each question was designed to solicit from the

I Ibid., pp. 38-106.

2 Communication Directors, General Conference Communication Department (Washington, D.C.: updated 1978 edition).

${ }^{3}$ Seventh-day Adventist Yearbook (Washington, D.C.: Review and Herald Pub. Assn., 1980), pp. 585-836. 
respondents as accurate a role description of the conference communication director from their view as possible.

The first section of the survey intended for conference communication directors only, reads as follows:

I. What offices do you currently hold in your conference?

A. Which one of your offices do you feel you were called to direct primarily or to give special emphasis to?

B. In reality, which one of your offices is the most time consuming?

C. Why?

The rationale behind these questions is simply to give the researcher insight into the balance or imbalance between the communication director's responsibilities for various conference offices and the time he needs to fulfill these responsibilities--especially as regards his duties for the communication department.

Except for the way the questions are worded, section II of the survey sent to the communication director and the first section of the two surveys sent to conference presidents and pastors are identical and are stated as follows:

II. (communication directors) From the following list, check only those activities you have actually engaged in during the past month.

I. (conference presidents) According to your knowledge, which of the following activities has your conference communication director(s) been engaged in during the past month?

I. (pastors) From the list below, please check those areas where you have received help during the past month from your conference communication director.

The purpose of these questions was to compare the activities of the conference communication director as perceived both by himself, 
his conference president, and the pastor he works with. It seemed to the researcher that an analysis of the responses of all three groups for this section of the survey would give a reasonably accurate picture of the activities engaged in by communication directors during a one-month period. It should also be noted that the time period specified for this section is limited to "the past month."

The researcher and his advisors agreed that this time limitation would help to avoid exaggeration in the respondents' answers.

Under survey section II (III for communication directors) entitled "Communication and Evangelism" (survey line number 77), the respondents are asked,

Specifically, what do you feel is the primary place of the local conference communication director in "finishing" God's work? The work of the conference communication director is:

A. Evangelism in terms of "seed-sowing."

B. Indirect evangelism in terms of "image-building."

C. Not evangelism in any sense.

The researcher's objective here was to appraise the work of the communication director as to its place in the evangelistic framework of the church, according to the perceptions of the respondents. Is the work of the communication director viewed as being basically evangelistic in nature or as merely a vehicle for carrying on the gospel commission?

The following question, rephrased for each group of respondents, is found under section III (IV for communication directors): 
(communication directors) In which of the following areas do you feel you could benefit if you had the opportunity of receiving additional training?

(pastors) In which of the following areas do you feel your conference communication director(s) would appreciate some professional or specialized training if it could be provided?

(conference presidents) In which of the following areas do you feel your conference communication director(s) might benefit by receiving additional training?

The rationale behind this question is to appraise the educational needs of the communication directors as perceived by the three groups of respondents.

Section IV of the survey ( $V$ for communication directors) is concerned with "the work of the conference communication director." The question asked is as follows:

Which of the following statements most closely reflects your opinion of the relative importance of the work of the local conference communication director?

A. Optiona 1: A good department to have, but could do without it on the local conference level.

B. Less important than other departments of the conference, but essentia].

C. Approximately equal in importance to other conference departments.

D. More important than some departments, but less important than others.

E. The most important department in the conference.

The reason behind this question is the need to find out from the respondents what they consider the importance of the communication department to be in relation to other conference departments. Is it really an important office for the conference to operate and maintain, or is it more of a "fringe" type of department, more of a novelty than a necessity on the local conference level? 
Section V (VI for communication directors) is the "general information" section and has been included for the following reasons:

1. Categories $A$ through $C$ dea 1 with age, sex, and denominational years of service and were included as an additional means of evaluating responses to the various sections of the questionnaire.

2. Categories $D$ through $G$ (same for pastors except that category $G$ is listed as number 130 ) are concenred with the respondents' educational background and experience in communication.

The researcher believes that the respondents' understanding of communication as seen by their responses to these four categories, indicates the degree of ability they have in using the "tools" of communication effectively. This is especially true of the responses given by the communication directors themselves.

3. Question 131 under section $V$ of the questionnaire sent to pastors reads as follows:

How well do you know your conference communication director?

A. I don't know who he is.

B. I know who he is but I have never met him.

C. I have met him but I have received little if any assistance from him.

D. I am well acquainted with him.

The reason for this question is to give the researcher some idea of what kind of a relationship exists between the conference communication director and the local church pastor.

Question $H$ under section VI of the questionnaire sent to communication directors reads as follows: 
During a typical 3-month period, what areas of communication do you find yourself concentrating on the most frequently?

The purpose of this question is to gain additional insights from the communication directors about the areas in communication they find the most time consuming. These responses also strengthen or augment the insights gained from section II concerning the activities that communication directors are engaged in during a one-month period.

Number 132 of the survey for pastors as well as roman numerals V.H and VI (I for conference presidents and communication directors) are the same although worded differentiy:

(pastors) What would you like to have the conference communication director do for you, your church, or institution that would be of most immediate benefit?

(conference presidents) What do you need right now that your conference communication director(s) could provide help with?

(communication directors) What would you like administrators, pastors or the church in general to do for you which would be of most immediate benefit to you and your department?

Al though worded differently, these three questions have the same basic objective--to discover the most important needs of communication directors, conference presidents, and pastors relative to the work and ministry of the conference communication director.

\section{Survey Implementation}

After the survey instrument was carefully refined, it was typed and then duplicated by the Andrews University duplicating department. Sufficient survey copies were provided for mailing to al1 three groups of respondents selected for the research project. As previously mentioned, these three groups consisted of 444 
pastors, 50 communication directors, and 48 conference presidents. The 50 communication directors as already noted were chosen from an updated 1978 communication directors booklet sent to the researcher from the General Conference of Seventh-day Adventists in Washington, D.C., whereas the 48 conference presidents and 444 pastors to be surveyed were selected from the 1980 Seventh-day Adventist Yearbook.

After cancelling the names of all ordained and licensed ministers serving as conference communication directors or conference presidents from the directory of workers portion of the 1980 Seventh-day Adventist Yearbook, the researcher chose one out of every ten of the remaining ordained and licensed pastors as the random sampling of pastors to be surveyed.

The first ministerial respondent was chosen by using a duplicated Table of Random Numbers from Glass and Stanley's Statistical Methods in Education and Psychology. ${ }^{1}$ After placing a page of these pre-arranged paired numbers on the floor, the researcher dropped a pen from about three feet high. It was pre-determined that whatever pair of numbers the pen marked, the number closest to the right would be the number on which the random sampling count would begin. On the third try the pen marked the numbers 67 . Since the number on the right was a seven; the researcher began his random selection of pastors with the seventh name and continued with every tenth name until the total of 444 was reached.

${ }^{1}$ Gene V. Glass and Julian C. Stanley, Statistical Methods in Education and Psychology (Englewood Cl iffs, NJ: Prentice-Ha11, 1970), pp. 510-12. 
Since a maximum return of questionnaires was desirable, certain steps were taken to assure the largest possible number of responses from the three groups of respondents. These steps were as follows:

1. A self-addressed, stamped envelope was enclosed for the respondents' convenience in returning the questionnaire.

2. A cover letter which accompanied the questionnaire and which explained the project (appendix G) was written to all of the respondents by James E. Chase, Director of the Department of Communication for the General Conference of Seventh-day Adventists.

3. A similar letter written by the researcher himself was also sent along with the questionnaire.

4. A separate instruction sheet was included with the questionnaire.

5. Each questionnaire was numbered for the purpose of recording its return.

Having taken these preliminary steps, the questionnaires were mailed to the potential respondents. From this initial mailing, 236 responses were received or 44 percent of the total possible respondents. Divided into groups the results were as follows:

1. Pastors--178 questionnaires received--40 percent

2. Communication Directors--35 questionnaires received-70 percent

3. Conference Presidents--23 questionnaires received-48 percent

Three weeks after the initial mailing, a reminder postcard 
was sent to those who had not yet returned their surveys and the researcher started calling the respondents by phone to back up the initial mailing and reminder cards. These phone calls continued during four of the five and a half months of the survey implementation period.

Due to the inaccuracy of the directory of workers list found in the 1980 SDA Yearbook, many of the questionnaires sent in by the ministers were considered unusable (table 1).

Six weeks after sending out the questionnaires the pastors' responses were as follows:

1. 176 usable questionnaires returned

2. 67 questionnaires not yet returned

3. 201 unusable questionnaires returned or accounted for With only 176 usable questionnaires for pastors in hand and 178 still outstanding, the researcher felt it advisable to send out a new set of questionnaires to obtain the 178 additional responses needed.

In order to do this, the researcher contacted all conference headquarters here in the United States by letter (appendix F) and by phone, requesting up-to-date lists of their ordained and licensed pastors. These lists were received from all but two of the conferences. They were then compiled alphabetically according to conferences with the exception of the two conferences which were again compiled from the 1980 Yearbook. According to this revised list the new number of ordained and licensed pastors actually involved in a pastoral church ministry is 2,441 as compared to the original figure of 4,349 given in the 1980 Yearbook. (See table 1 for the reason for these differences.) 
TABLE 1

CATEGORIES OF UNACCEPTABLE RESPONSES

\begin{tabular}{|l|c|c|c|}
\hline Respondents & $\begin{array}{l}\text { Wrong } \\
\text { Occupation }\end{array}$ & Retired & 0ther \\
\hline Presidents & - & - & 7 \\
\hline $\begin{array}{c}\text { Communication } \\
\text { Directors }\end{array}$ & $-\ldots 1$ & 1 \\
\hline Ministers & 104 & 91 & 43 \\
\hline
\end{tabular}


Since this new list was more up-to-date and accurate than the ministerial listing in the 1980 yearbook, the researcher felt it appropriate to use the new figure of 2,441 instead of 4,349 from which to choose his random sampling of pastors. Thus, the new random sampling size needed in order to be statistically. accurate for a population of 2,441 was 332 instead of the original 354 for a population of 4,349 .

After omitting the names from the new list of all of the pastors already sent questionnaires, the researcher followed his original method of selecting the new random sampling list. He used a duplicated page of random numbers from Glass and Stanley's Statistical Methods in Education and Psychology. ${ }^{1}$ He then placed the page on the floor and dropped a felt pen from a height of about three feet. The pen marked the numbers 14 . Having predetermined to use the number of the right, the researcher chose the number four to begin his random sampling from the new pastoral 1ist. Starting with the fourth minister he continued through the list from then on choosing every eighth pastor and finally ending up with a random sampling total of 277 . Approximately ten weeks after the first set of questionnaires was mailed, additional questionnaires were prepared and mailed to the new sampling of pastors, together with the materials previously enclosed.

Two and a half months after the first set of questionnaires was sent, seven conference communication directors, fifteen conference presidents, and forty-three pastors (from the first pastoral

$$
\text { I Ibid. }
$$


group) had not responded. These were sent additional questionnaires as a reminder, with copies of the original accompanying letters.

Three and a half weeks after the second set of questionnaires for pastors had been sent out, 136, or 49 percent had been returned, with 141 still outstanding. Postcards were then sent to the, remaining 141 as reminders.

The deadline for all returns was set for September 25, 1980. By that date, 95.83 percent of the presidents' questionnaires, 100 percent of the communication directors' questionnaires, and 94.45 percent of the pastors' questionnaires had been returned (table 2). It should be noted that the number of usable questionnaires received from ministers was 443 (table 2), 111 more than what was actually needed to be statisticaliy accurate for the population of pastors surveyed. The final number of questionnaires, letters, postcards, and phone calls (mostly long distance) involved in the survey procedure are noted in table 3.

The results of all of the questionnaires were then transferred to Op-scan computer forms by the researcher and turned over to the Andrews University computing center for tabulation of the results. Finally the researcher gave careful study to the computer printout sheets, analyzing and comparing different sections from which he designed approximately seventy tables and figures used in the following chapter concerning the survey results. 
TABLE 2

SURVEY RESULTS

\begin{tabular}{|c|c|c|c|c|c|}
\hline Resporidents & $\begin{array}{c}\text { Surveys } \\
\text { Mailed }\end{array}$ & $\begin{array}{c}\text { Surveys } \\
\text { Received }\end{array}$ & $\begin{array}{c}\text { Percentage } \\
\text { Received }\end{array}$ & $\begin{array}{c}\text { Number } \\
\text { Usable }\end{array}$ & $\begin{array}{c}\text { Number } \\
\text { Unusable }\end{array}$ \\
\hline Presidents & 48 & 46 & 95.83 & 39 & 7 \\
\hline $\begin{array}{c}\text { Communication } \\
\text { Directors }\end{array}$ & 50 & 50 & 100.00 & 49 & 1 \\
\hline Ministers & 721 & 681 & 94.45 & 443 & 238 \\
\hline Totals & 819 & 777 & 96.76 & 531 & 246 \\
\hline
\end{tabular}


TABLE 3

METHODS OF CONTACTING RESPONDENTS

\begin{tabular}{|c|c|c|c|c|c|c|c|}
\hline Respondents & $\begin{array}{l}\text { Question- } \\
\text { naires }\end{array}$ & Letters & Postcards & Phone Calls & $\begin{array}{l}\text { Additional } \\
\text { Question- } \\
\text { naires }\end{array}$ & $\begin{array}{l}\text { Additional } \\
\text { Letters } \star\end{array}$ & $\begin{array}{l}\text { Phone Call } \\
\text { Attempts }\end{array}$ \\
\hline Presidents & 48 & 96 & 22 & 25 & 30 & 50 & - \\
\hline $\begin{array}{l}\text { Communication } \\
\text { Directors }\end{array}$ & 50 & 100 & 11 & 10 & 11 & 28 & 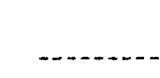 \\
\hline Ministers & 721 & 1442 & 401 & 294 & 229 & 390 & 273 \\
\hline Totals & 819 & 1638 & 437 & 329 & 273 & 468 & 273 \\
\hline
\end{tabular}


CHAPTER $V$

RESULTS OF THE QUESTIONNAIRE

Introduction

This chapter reports the perceptions of pastors, local conference communication directors, and local conference presidents concerning "The Role of the Local Conference Communication Director in the. United States." These perceptions were gained from three questionnaires mailed to the three groups of respondents. The questionnaires were essentially identical in all of the main sections except for some slight variations where specific information was needed from each distinctive group. For the purposes of this study all three questionnaires are considered as one.

The areas dealt with in the questionnaire are as follows: (1) conference offices currently held by local conference communication directors; (2) assistance given by the local conference communication director; (3) the primary place of the local conference communication director in "finishing God's work"; (4) professional or specialized training needed by local conference communication directors; (5) the relative importance of the work of the local conference communication director; (6) educational background, training, and experience of respondents; (7) degree of acquaintance pastors have with the local conference communication director; (8) areas concentrated on the most frequently by local 
conference communication directors during a typical three month period; (9) areas where the local conference communication director himself could use help, as well as give needed assistance to pastors and conference presidents.

The data received from each of those surveyed is reported on the following pages, stressing certain points perceived by the researcher as being of importance relative to the study in hand. This report is followed by a summary and analysis of all the data received through the research avenues previously mentioned.

\section{Offices. Held by Local Conference Communication Directors}

According to the survey results (tables 4 through 7 ) most local conference communication directors hold one or more offices in addition to their responsibilities for the department of communication. The office the respondents indicated is most often held concurrently with the communication department is the department of education (24.49 percent, table 5). This same department is also listed by the respondents as being the office, next to communication, which they are called to direct primarily (these are offices looked at as major departments by administration) or to give special emphasis to (24.49 percent, table 6). They also listed it as the most time consuming department (these are offices seen in reality to be very time consuming) next to the communication department (20.47 percent, table 7).

A number of respondents indicated they had difficulties in trying to care for both the communication and education departments simultaneously. One remarked: 


\section{TABLE 4}

CONFERENCE POSITIONS HELD BY CONFERENCE COMMUNICATION DIRECTORS

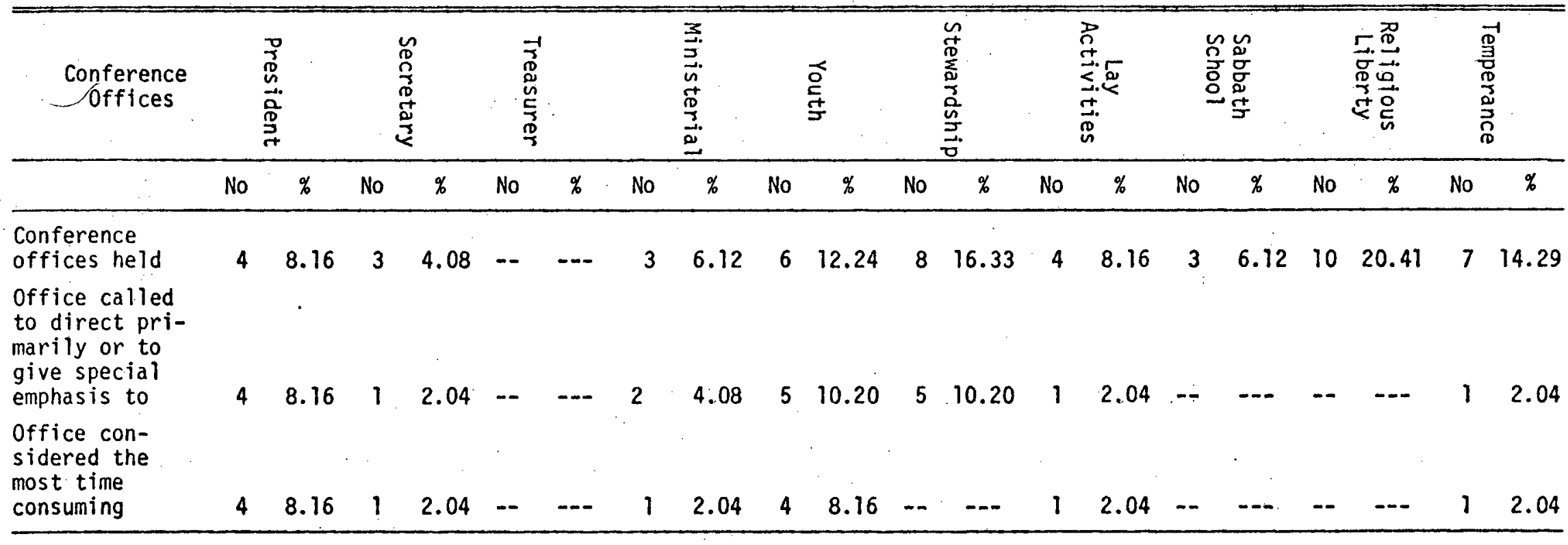


TABLE 4--Continued

\begin{tabular}{|c|c|c|c|c|c|c|c|c|c|c|c|c|c|c|c|c|c|c|}
\hline \multirow[t]{2}{*}{$\begin{array}{c}\text { Conference } \\
\text { Offices }\end{array}$} & \multirow{2}{*}{ No } & \multirow{2}{*}{$\frac{\frac{T}{\mathbb{D}}}{\frac{0}{5}}$} & \multirow{2}{*}{ No } & \multirow{2}{*}{ 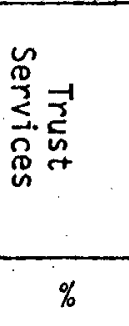 } & & \multirow{2}{*}{ 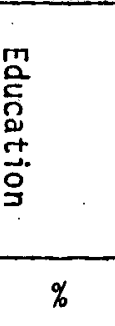 } & \multirow{2}{*}{ No } & \multirow{2}{*}{ 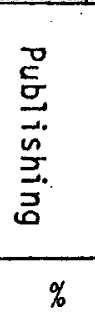 } & \multirow{2}{*}{\multicolumn{2}{|c|}{ 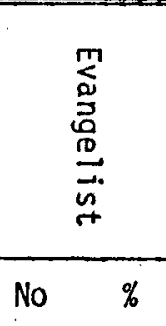 }} & \multirow[t]{2}{*}{ No } & \multirow[t]{2}{*}{ 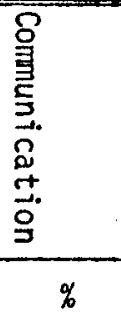 } & \multirow[b]{2}{*}{ No } & \multirow{2}{*}{ 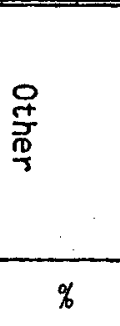 } & \multirow{2}{*}{\multicolumn{2}{|c|}{ 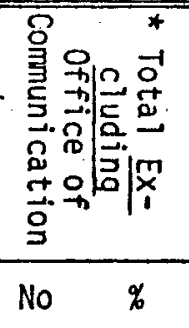 }} & \multicolumn{2}{|c|}{ 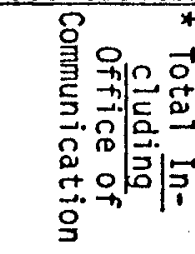 } \\
\hline & & & & & & & & & & & & & & & & & No & $\%$ \\
\hline $\begin{array}{l}\text { office called } \\
\text { to direct pri- } \\
\text { marily or to } \\
\text { give special }\end{array}$ & & & & . & & & & & & & & & & & & & & \\
\hline emphasis to & 1 & 2.04 & 3 & 6.12 & 12 & 24.49 & -- & $-\cdots$ & $-\cdots$ & -- & 17 & 34.69 & 2 & 4.08 & 37 & 75.51 & 56 & 114.3 \\
\hline $\begin{array}{l}\text { Office con- } \\
\text { sidered the } \\
\text { most time }\end{array}$ & & & & & & & & & & & & & & & & & & \\
\hline consuming & 1 & 2.04 & 3 & 6.12 & 10 & 20.41 & - & $\ldots$ & -- & -- & 16 & 32.65 & 3 & 6.12 & 31 & 63.27 & 47 & 95.92 \\
\hline
\end{tabular}

*Total Percentages 
TABLE 5

CONFERENCE POSITIONS HELD BY CONFERENCE COMMUNICATION DIRECTORS

\begin{tabular}{lcc}
\hline \multirow{2}{*}{$\begin{array}{c}\text { Conference } \\
\text { Offices }\end{array}$} & \multicolumn{2}{c}{$\begin{array}{c}\text { Conference } \\
\text { Offices Held }\end{array}$} \\
\cline { 2 - 3 } Communication & No. & $\%$ \\
Education & 48 & $97.96 *$ \\
Religious Liberty & 12 & 24.49 \\
Stewardship & 10 & 20.41 \\
Temperance & 8 & 16.33 \\
Youth & 7 & 14.29 \\
Health & 6 & 12.24 \\
Trust Services & 6 & 12.24 \\
Lay Activities & 6 & 12.24 \\
President & 4 & 8.16 \\
Sabbath School & 4 & 8.16 \\
Ministerial & 3 & 6.12 \\
Secretary & 3 & 6.12 \\
Treasurer & -- & 4.08 \\
Publishing & -- & -1 \\
Evangelist & & $-1-$ \\
\hline
\end{tabular}

*Al though 49 usable survey responses were received from conference communication directors, only 48 (97.96 percent) said they actually were communication directors. The one who failed to indicate his responsibilities for that department did fill out the survey sent to him, but could have unintentionally neglected to check the blank indicating his connection with that department. 
TABLE 6

CONFERENCE POSITIONS HELD BY CONFERENCE COMMUNICATION DIRECTORS

\begin{tabular}{|c|c|c|}
\hline \multirow[t]{2}{*}{$\begin{array}{c}\text { Conference } \\
\text { Offices }\end{array}$} & \multicolumn{2}{|c|}{$\begin{array}{l}\text { Office Called to } \\
\text { Direct Primarily } \\
\text { or to Give Spec- } \\
\text { ial Emphasis to }\end{array}$} \\
\hline & No. & $\%$ \\
\hline Communication & 17 & 34.69 \\
\hline Education & 12 & 24.49 \\
\hline Youth & 5 & 10.20 \\
\hline Stewardship & 5 & 10.20 \\
\hline President & 4 & 8.16 \\
\hline Trust Services & 3 & 6.12 \\
\hline Ministerial & 2 & 4.08 \\
\hline Secretary & 1 & 2.04 \\
\hline Lay Activities & 1 & 2.04 \\
\hline Health & 1 & 2.04 \\
\hline Temperance & 1 & 2.04 \\
\hline Sabbath School & -- & -- \\
\hline Treasurer & -- & --- \\
\hline Publishing & -- & -- \\
\hline Evangelist & -- & -- \\
\hline Religious Liberty & -- & -- \\
\hline
\end{tabular}


TABLE 7

CONFERENCE POSITIONS HELD BY CONFERENCE COMMUNICATION DIRECTORS

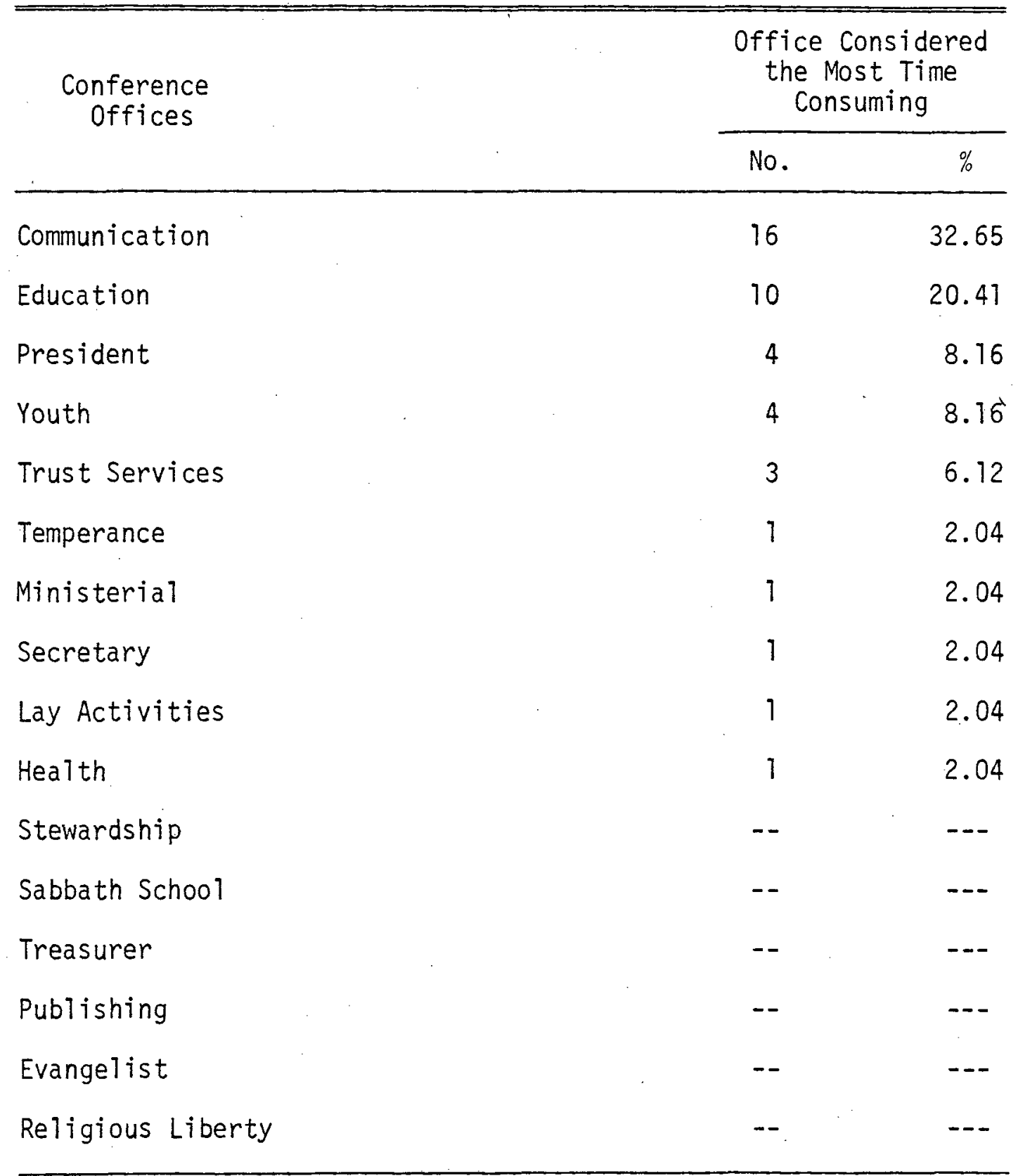


To care for the education department is demanding and a constant responsibility. Many lives are directly affected. I would be pleased if I could be relieved of the responsibility for the communication department. Education is a full-time job, and that is where I have had my training.

Another respondent said that the reason he had to spend so much time caring for the education department was because of his responsibilities in looking after "73 full time employees and 21 part-time employees" in conference operated schools.

A third conference communication director who also cared for the education department felt that his responsibilities as education secretary were very time consuming due to his involvement with various "personnel and conference policies." His rather concerned plea was "for more time to accomplish public relations activities by assigning additional trained help or by rearranging responsibilities."

One respondent in education and communication suggested that the communication department be given "to someone else who could devote the time needed to making it effective."

Based on the views of these and other respondents it appears that these two departments (communication and education), when cared for by one individual, are also the two most incompatible with each other. The time needed for the effective administration of both departments is such that either one or the other will predominate when under the care of one conference administrator. Therefore, a separation of these two departments seems to be a logical approach to a more successful and effective operation of both departments. According to the respondents, the "religious liberty" department (20.41 percent, table 5 ) is the second most commoniy 
held additional office of the communication director. However, the respondents are generally agreed that it is not an office which they are called to direct primarily or to give special emphasis to (no percentage, table 6), nor in their opinion is it very time consuming (no percentage, table 7). The third office most often cared for by communication directors is the office of stewardship (16.33 percent, table 5). Both stewardship and the youth departments (10.20 percent, table 6) rank second to education as requiring the primary attention of conference communication directors. However, it should be noted that the percentage responses for both of these departments falls far below the response given to the department of education. The difference is more than 14 percent.

Next to education, the offices of president 1 and youth ( 8.16 percent, table 7) are seen as the second most time-consuming departments. Once again however, the large percentage gap between the department of education and those of president and youth should be noted (approximately 12 percent as seen in table 7).

In order to clarify some technical reporting of the data in table 4 , it should be noted that the section entitled "total excluding office of communication," is referring to the total number of offices held by conference communication directors with the exception of the communication department. Those offices "called to

TOriginally, as indicated in chapter IV entitled a "Description of Survey Procedures," p. 62, a11 conference presidents who served their conferences as communication directors were, for the purposes of this project, to be considered only as communication directors. However, due to a lack of accurate information, or a shift of conference positions or personnel during the process of this research project, four conference presidents who were also communication directors showed up among the respondents. These four were included as it was felt they would not significantiy aiter the results of this section of the survey. 
direct primarily or to give special emphasis to," as well as the offices "considered the most time consuming," are in this section also viewed as combined totals. This is also true for the section that immediately follows, "total including office of communication," but with the addition of the office of communication as part of the combined total. Thus it can be seen that the number and percentage totals for these two sections are in several incidences considerably higher than the total number of respondents.

As an example (table 4), there are a total of 129 offices (263.3 percent) held by forty-nine conference communication directors including the office of communication. There are also fifty-six offices (114.3 percent, table 4) which, according to their view, conference communication directors feel "called to direct primarily or to give special emphasis to." This seems to indicate, as the survey results show, that some of the communication directors feel "called to direct primarily or to give special emphasis to" more than one department at a time. In other words some of the communication directors have at least two offices to give special emphasis to.

Table 4, under the column marked "other," lists the responses of those conference communication directors who indicated their responsibilities for departments or services other than those $l$ isted in the survey. The researcher finds no special importance in these responses for his study, and has listed them in appendix I. 


\section{Assistance Given by the Local Conference Communication Director}

This section concerns the perceptions of pastors, conference communication directors, and conference presidents regarding the activities engaged in by conference communication directors during a one month period (tables 8 through 17 and figures 1 through 7).

As tables 12 through 14 and figures 4 through 7 show, both conference presidents and communication directors indicate that they believe conference communication directors are engaged in up to 33 percent more activities during a one month period than that perceived by pastors (table 14 and figure 7 ). This is shown by the presidents' overa 11 average of 40.06 percent (table 14, last column), which is 24.41 percent higher than that of the pastors $(15.65$ percent, table 14, last column), and the conference communication directors' average of 49.49 percent which is 33.84 percent higher than the pastors (table 14, last column).

In part at least, this perceptual difference can be seen by the remarks of one minister who stated: "I haven't heard from our communication director for months except to advertise local conference offerings."

Another minister remarked: "This whole section is answered with a 'no' for I haven't received any help from him."

And a third said: "A communication director for the union would be sufficient, unless there is a different emphasis given." According to the pastors' perceptions, the activity most regularly engaged in by conference communication directors during 



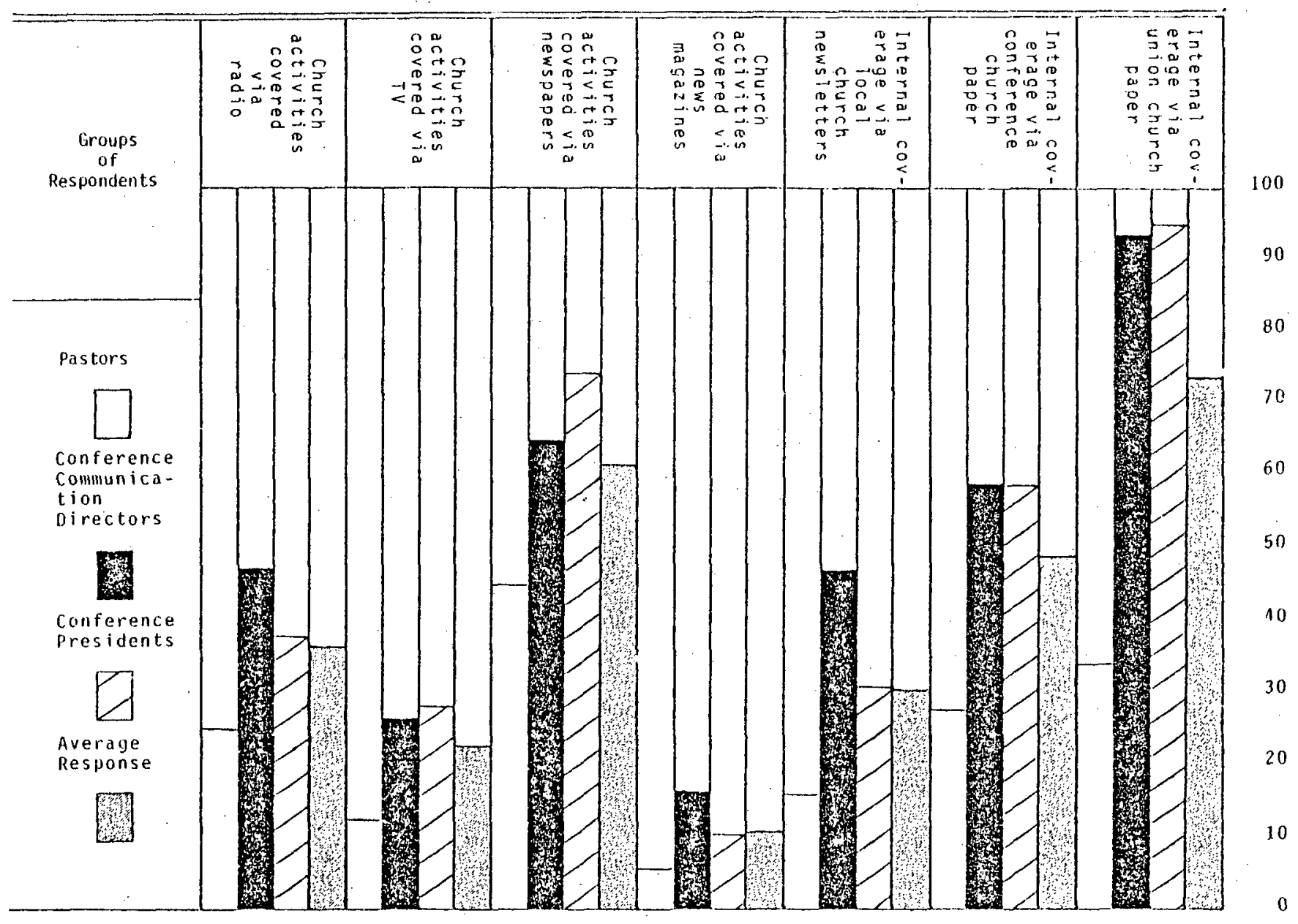

Fig. 1. Activities engaged in or assistance given by the Conference Communication Director during a one month period as perceived by the following respondents. 



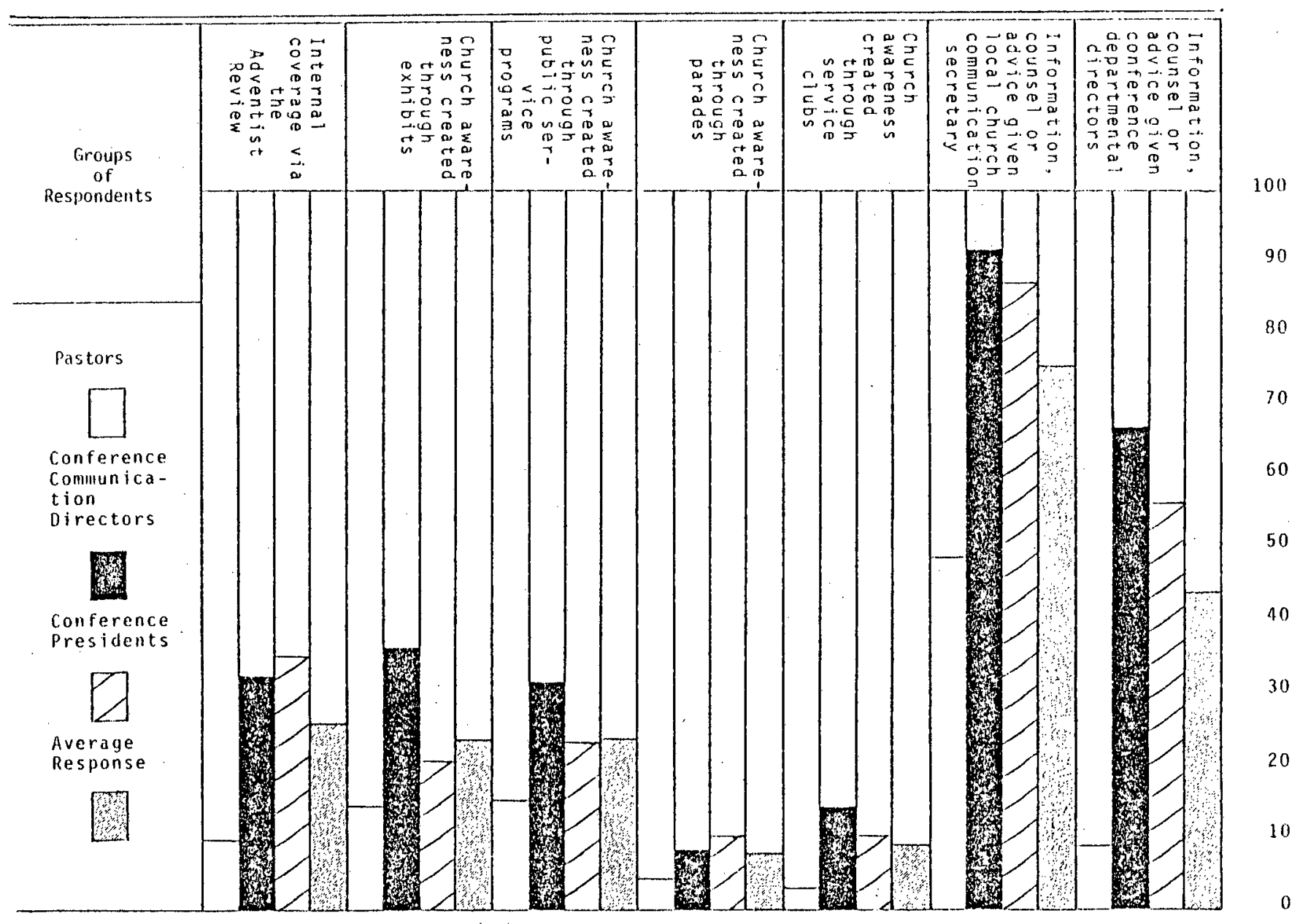

Fig. 2. Activities engaged in or assistance given by the Conference Communication Director during a one month period as perceived by the following respondents. 



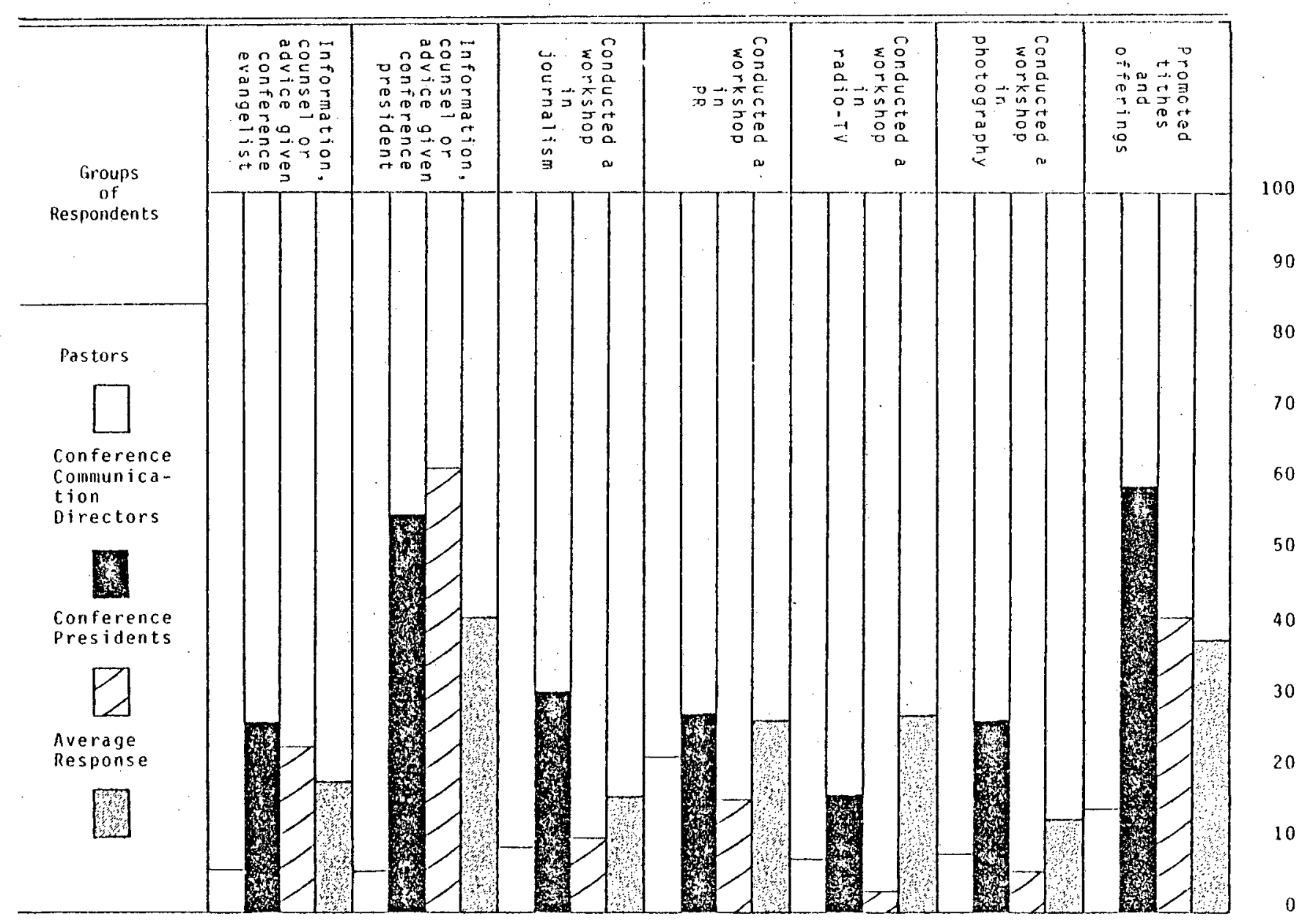

Fig. 3. Activities engaged in or assistance given by the Conference Communication Director during a one month period as perceived by the following respondents. 



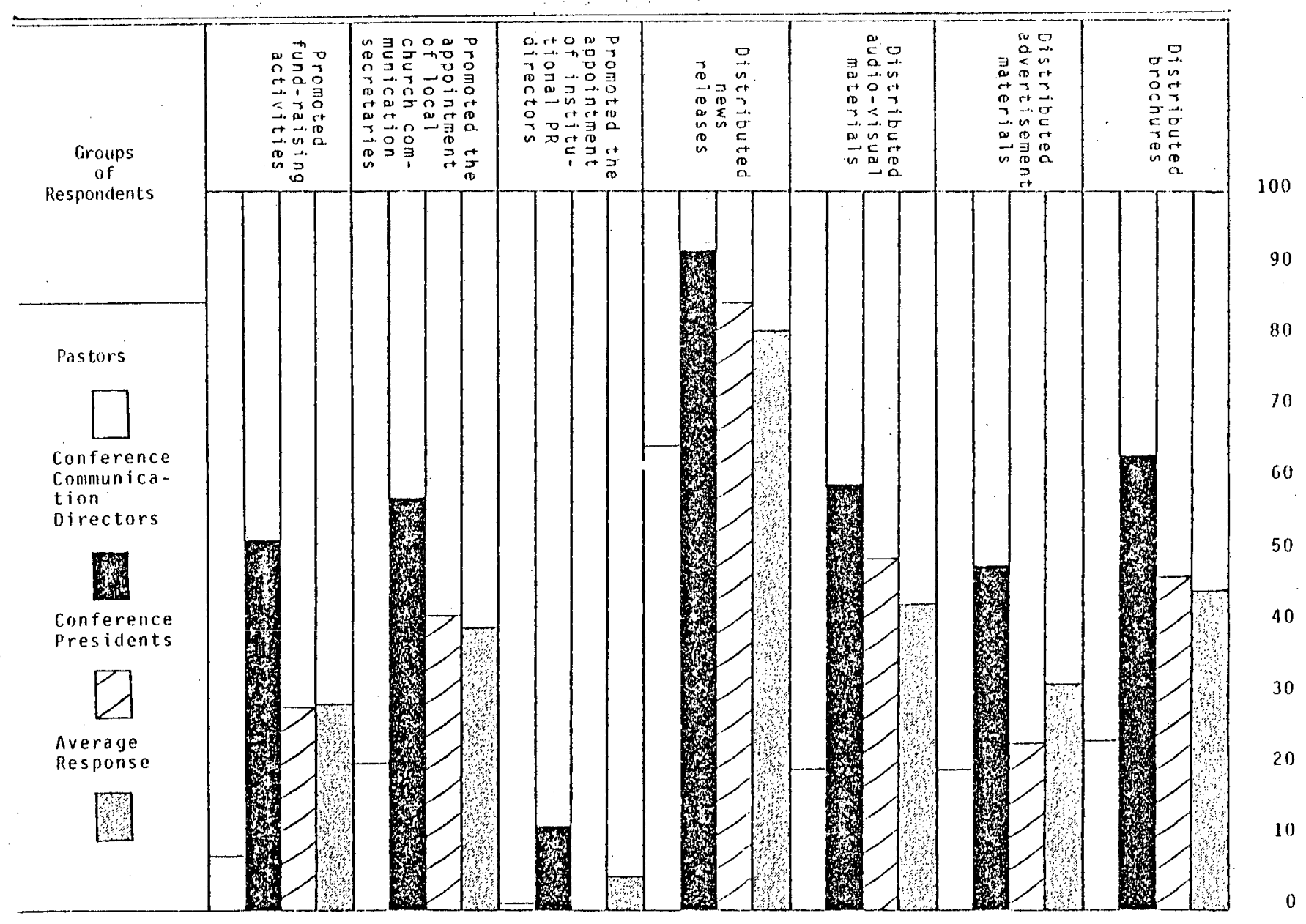

Fig. 4. Activities engaged in or assistance given by the Conference Communication Director during a one month period as perceived by the following respondents. 



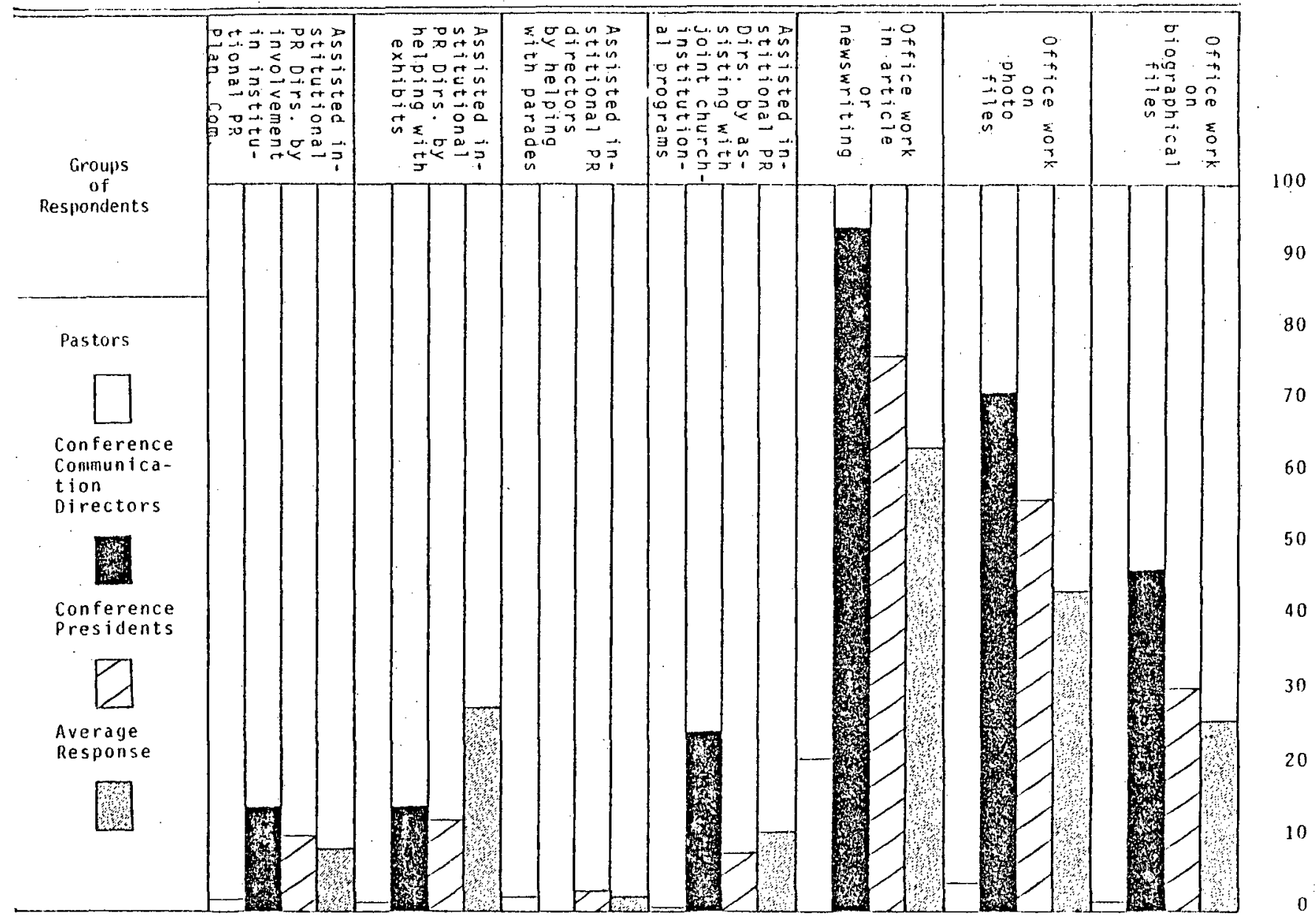

Fig. 5. Activities engaged in or assistance given by the Conference Communication Director during a one month period as perceived by the following respondents. 



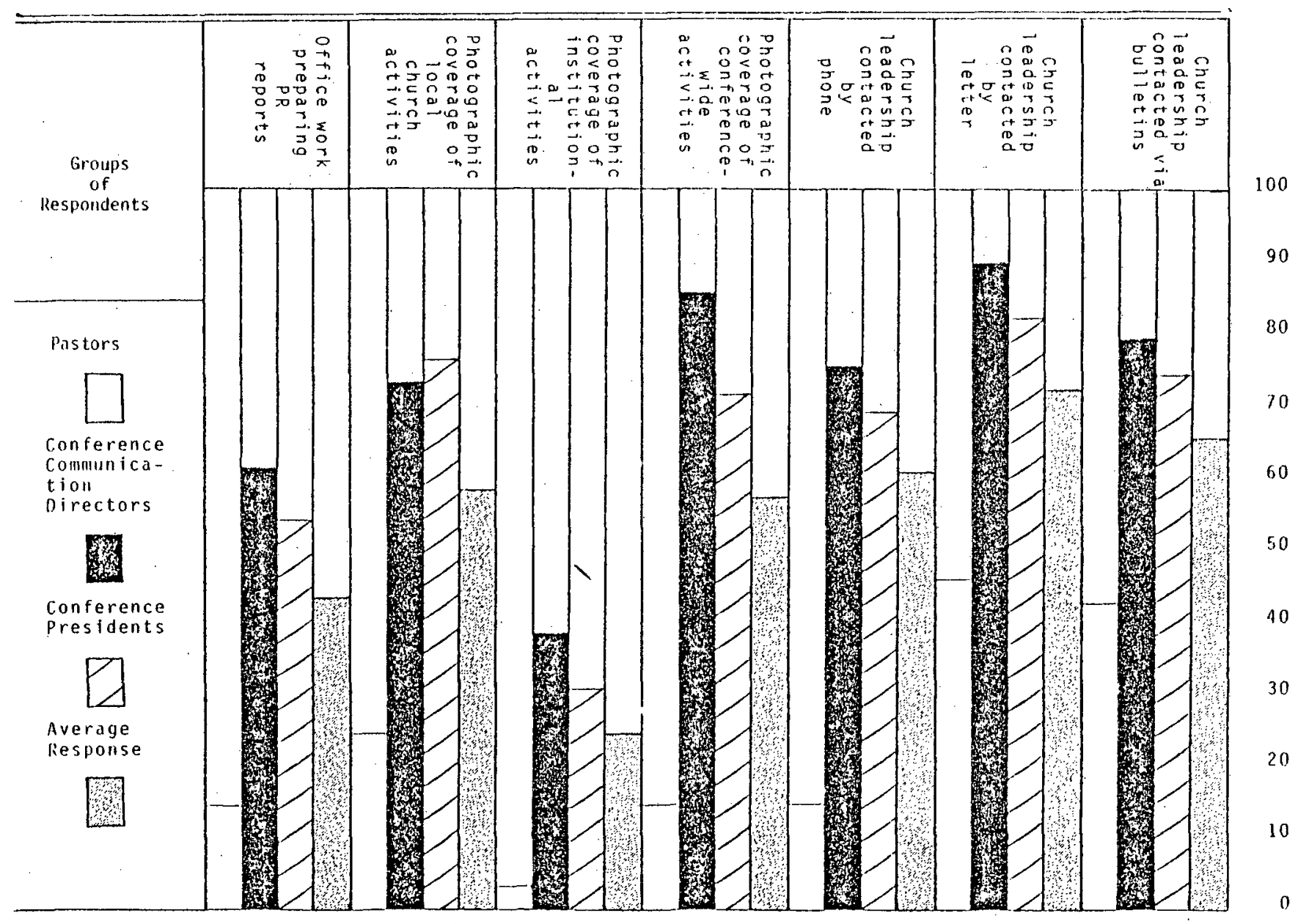

Fig. 6. Activities engaged in or assistance given by the

Conference Communication Director during a one month period as perceived by the following respondents. 



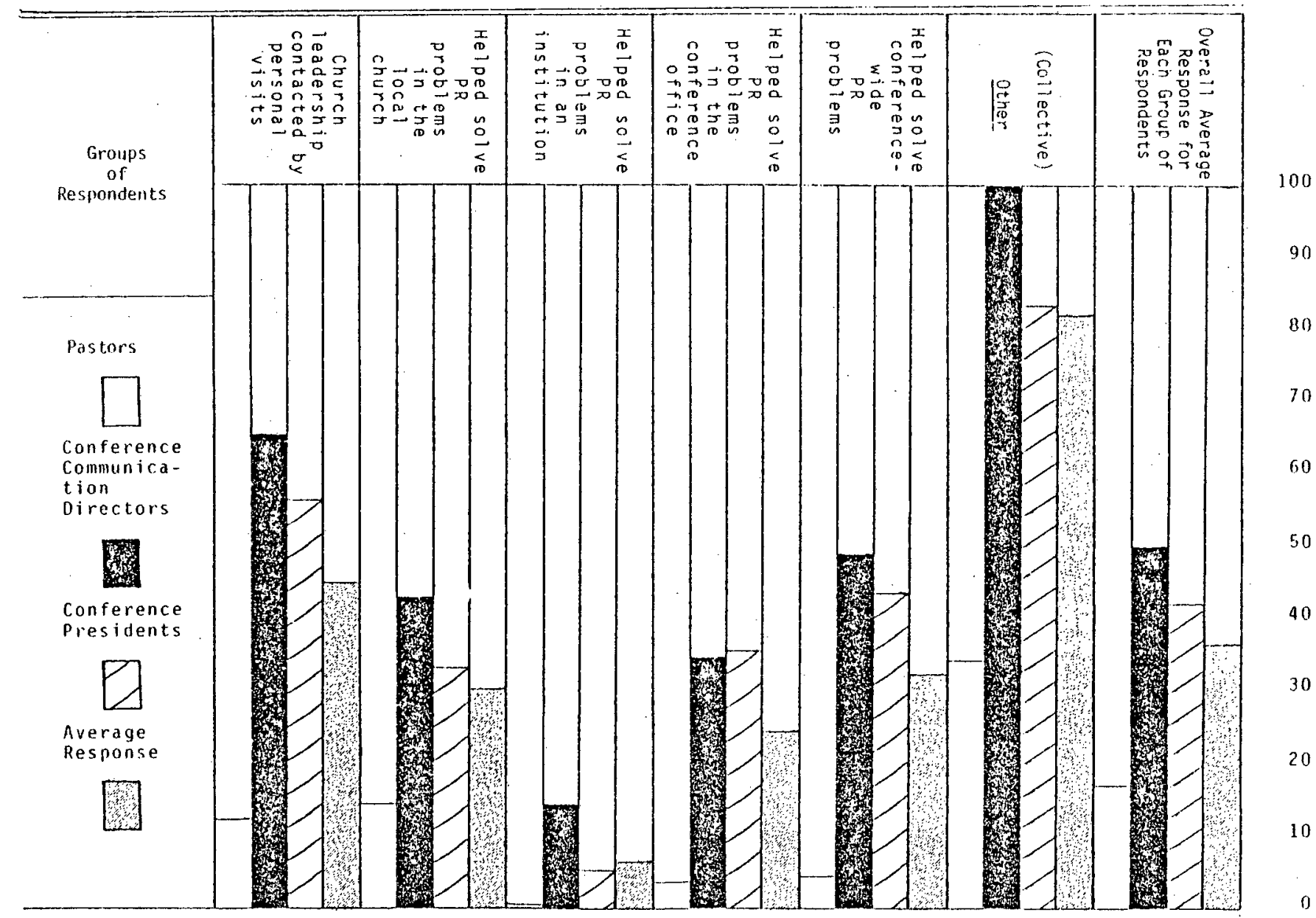

$\vec{\circ}$

Fig. 7. Activities engaged in or assistance given by the Conference Communication Director during a one month period as perceived by the following respondents. 
a one month period is their "distribution of news releases" (64.79 percent, table 15). The next activity most engaged in according to pastors is the communication directors' giving of "information, counsel or advice to local church communication secretaries" (48.98 percent, table 15). It is of interest to note that there is almost a 16 point percentage difference between the activity given first place and the one viewed as second. The third activity most often engaged in by communication directors, according to pastors, is their maintaining of contact with "church leadership... by letter" (45.82 percent, table 15).

In comparison, communication directors give "office work in article or newswriting" (93.88 percent, table 16) and "internal coverage via the union paper" (93.88 percent, table 16) as the two activities they see themselves the most frequently involved in during a one month period. They list "information, counsel, or advice given to local church communication secretaries" (91.84 percent, table 16) and distribution of "news releases" (91.84 percent, table 16) in second place. Their third most engaging activity, according to the communication directors themselves, is their "contacting of church leadership by letter" (89.80 percent, table 16).

Conference presidents list "internal coverage via the union paper" (94.87 percent, table 17) as being the activity they perceive the conference communication director being most involved with during a one month period. Second in their view is the "information, counsel, or advice given by the conference communication director to local church communication secretaries" (87.18 percent, table 17), and third is the communication director's 
TABLE 15

ACTIVITIES ENGAGED IN OR ASSISTANCE GIVEN BY THE CONFERENCE COMMUNICATION DIRECTOR DURING A ONE MONTH PERIOD AS PERCEIVED BY PASTORS

\begin{tabular}{|c|c|c|c|}
\hline & \multirow{2}{*}{ Activities } & \multicolumn{2}{|c|}{ Pas tors } \\
\hline & & No. & $\%$ \\
\hline 1. & Distributed news releases & 287 & 64.79 \\
\hline & $\begin{array}{l}\text { Information, counsel, or advice given } \\
\text { local church communication secretary }\end{array}$ & 217 & 48.98 \\
\hline 3. & Church leadership contacted by letter & 203 & 45.82 \\
\hline 4. & $\begin{array}{l}\text { Church activities covered via } \\
\text { newspapers }\end{array}$ & 198 & 44.70 \\
\hline 5. & $\begin{array}{l}\text { Church leadership contacted via } \\
\text { bulletins }\end{array}$ & 189 & 42.66 \\
\hline & $\begin{array}{l}\text { Internal coverage via union church } \\
\text { paper }\end{array}$ & 151 & 34.09 \\
\hline 7. & $\begin{array}{l}\text { Internal coverage via conference } \\
\text { church paper }\end{array}$ & 124 & 27.99 \\
\hline 8. & Church activities covered via radio & 110 & 24.83 \\
\hline & $\begin{array}{l}\text { Photographic coverage of local church } \\
\text { activities }\end{array}$ & 108 & 24.38 \\
\hline 10. & Distributed brochures & 104 & 23.48 \\
\hline 11. & Conducted a workshop in PR & 97 & 21.90 \\
\hline 12. & office work in article or newswriting & 93 & 20.99 \\
\hline 13. & $\begin{array}{l}\text { Promoted the appointment of local } \\
\text { church communication secretaries }\end{array}$ & 89 & 20.09 \\
\hline 14. & Distributed advertisement materials & 88 & 19.86 \\
\hline 15. & Distributed audio-visual materials & 87 & 19.64 \\
\hline 16. & $\begin{array}{l}\text { Internal coverage via local church } \\
\text { newsletters }\end{array}$ & 71 & 16.03 \\
\hline 17. & $\begin{array}{l}\text { Church awareness created through } \\
\text { public service programs }\end{array}$ & 68 & 15.35 \\
\hline 18. & Church leadership contacted by phone & 65 & 14.67 \\
\hline 19. & $\begin{array}{l}\text { Photographic coverage of conference- } \\
\text { wide activities }\end{array}$ & 64 & 14.45 \\
\hline 20. & $\begin{array}{l}\text { Helped solve PR problems in the } \\
\text { local church }\end{array}$ & 64 & 14.45 \\
\hline 21 & Promoted tithes and offerings & 64 & 14.45 \\
\hline
\end{tabular}


TABLE 15--Continued

22. Office work preparing PR reports

23. Church awareness created through exhibits

P a s tors

No.

63

14.22

24. Church leadership contacted by

24. Church leadership
personal visits

63

14.22

56

12.64

25. Church activities covered via TV

56

12.64

26. Internal coverage via the Adventist Review

43

9.41

27. Information, counsel, or advice given conference departmental directors

40

9.03

28. Conducted a workshop in journalism

39

8.80

29. Conducted a workshop in photography

35

7.90

30. Promoted fund-raising activities

33

7.45

31. Conducted a workshop in radio-TV

28

6.32

32. Information, counsel, or advice given conference evangelist

33. Information, counsel, or advice given conference president

34. Church activities covered via news magazines

35. Church awareness created through parades

36. Helped solve conference-wide PR problems

37. Office work on photo files

38. Helped solve PR problems in the conference office

39. Photo coverage of institutional activities

40. Church awareness created through service clubs

41. Assisted institutional PR directors by helping with parades

42. Assisted institutional PR directors by involvement in institutional PR planning committees 
TABLE 15--Continued

$$
\text { Activities }
$$

$\frac{P \text { a s tors }}{\text { No. }}$

43. Assisted institutional PR directors by helping with exhibits

44. Office work on biographical files

4 .90

45. Promoted the appointment of institutional PR directors

4

.90

2

46. Assisted institutional PR directors by assisting with joint churchinstitutional programs

47. Helped solve PR problems in an institution 
ACTIVITIES ENGAGED IN OR ASSISTANCE GIVEN BY THE CONFERENCE COMMUNICATION DIRECTOR DURING A ONE MONTH PERIOD AS PERCEIVED BY CONFERENCE COMMUNICATION DIRECTORS

\begin{tabular}{|c|c|c|c|}
\hline & \multirow[t]{2}{*}{ Activities } & \multicolumn{2}{|c|}{$\begin{array}{l}\text { Conference } \\
\text { Communication } \\
\text { Directors }\end{array}$} \\
\hline & & No. & $\%$ \\
\hline 1. & Office work in article or newswriting & 46 & 93.88 \\
\hline 2. & Internal coverage via union church paper & 46 . & 93.88 \\
\hline & $\begin{array}{l}\text { Information, counsel, or advice given } \\
\text { local church communication secretary }\end{array}$ & 45 & 91.84 \\
\hline 4. & Distributed news releases & 45 & 91.84 \\
\hline 5. & Church leadership contacted by letter & 44 & 89.80 \\
\hline 6. & $\begin{array}{l}\text { Photographic coverage of Conference- } \\
\text { wide activities }\end{array}$ & 42 & 85.71 \\
\hline 7. & Church leadership contacted via bulletins & 39 & 79.59 \\
\hline 8. & Church leadership contacted by phone & 37 & 75.51 \\
\hline 9. & $\begin{array}{l}\text { Photographic coverage of local church } \\
\text { activities }\end{array}$ & 36 & 73.47 \\
\hline 10. & Office work on photo files & 35 & 71.43 \\
\hline 11. & $\begin{array}{l}\text { Information, counsel, or advice given } \\
\text { conference departmental directors }\end{array}$ & 33 & 67.35 \\
\hline & $\begin{array}{l}\text { Church leadership contacted by personal } \\
\text { visits }\end{array}$ & 32 & 65.31 \\
\hline 13. & Church activities covered via newspapers & 32 & 65.31 \\
\hline 14. & Distributed brochures & 31 & 63.27 \\
\hline 15. & Office work preparing PR reports & 30 & 61.22 \\
\hline 16. & Distributed audio-visual materials & 29 & 59.18 \\
\hline 17. & Promoted tithes and offerings & 29 & 59.18 \\
\hline & $\begin{array}{l}\text { Internal coverage via conference } \\
\text { church paper }\end{array}$ & 29 & 59.18 \\
\hline & $\begin{array}{l}\text { Promoted the appointment of local } \\
\text { church communication secretaries }\end{array}$ & 28 & 57.14 \\
\hline 20. & $\begin{array}{l}\text { Information, counsel, or advice given } \\
\text { conference president }\end{array}$ & 27 & 55.10 \\
\hline & Promoted fund-raising activities & 25 & 51.02 \\
\hline 22. & Distributed advertisement materials & 25 & 51.02 \\
\hline
\end{tabular}




\begin{tabular}{|c|c|c|c|}
\hline \multicolumn{2}{|r|}{ Activities } & \multicolumn{2}{|c|}{$\begin{array}{l}\text { Conference } \\
\text { Communication } \\
\text { Directors }\end{array}$} \\
\hline & & No. & $\%$ \\
\hline 23. & $\begin{array}{l}\text { Helped solve conference-wide PR } \\
\text { problems }\end{array}$ & 24 & 48.98 \\
\hline 24. & Office work on biographical files & 23 & 46.94 \\
\hline 25. & $\begin{array}{l}\text { Internal coverage via local church } \\
\text { newsletters }\end{array}$ & 23 & 46.94 \\
\hline 26. & Church activities covered via radio & 23 & 46.94 \\
\hline 27. & $\begin{array}{l}\text { Helped solve PR problems in the } \\
\text { local church }\end{array}$ & 21 & 42.86 \\
\hline 28. & Conducted a workshop in PR & 21 & 42.86 \\
\hline 29. & $\begin{array}{l}\text { Photographic coverage of institutional } \\
\text { activities }\end{array}$ & 19 & 38.78 \\
\hline 30. & $\begin{array}{l}\text { Church awareness created through } \\
\text { exhibits }\end{array}$ & 18 & 36.73 \\
\hline 31. & $\begin{array}{l}\text { Helped solve PR problems in the } \\
\text { conference office }\end{array}$ & 17 & 34.69 \\
\hline 32. & $\begin{array}{l}\text { Internal coverage via the Adventist } \\
\text { Review }\end{array}$ & 16 & 32.65 \\
\hline 33. & $\begin{array}{l}\text { Church awareness created through } \\
\text { public service programs }\end{array}$ & 16 & 32.65 \\
\hline 34. & Conducted a workshop in journalism & 15 & 30.61 \\
\hline 35. & Church activities covered via TV & 13 & 26.53 \\
\hline 36. & $\begin{array}{l}\text { Information, counsel, or advice given } \\
\text { conference evangelist }\end{array}$ & 13 & 26.53 \\
\hline 37. & Conducted a workshop in photography & 13 & 26.53 \\
\hline 38. & $\begin{array}{l}\text { Assisted institutional PR directors by } \\
\text { assisting with joint church- } \\
\text { institutional programs }\end{array}$ & 12 & 24.49 \\
\hline 39. & Conducted a workshop in radio-TV & 8 & 16.33 \\
\hline 40 . & $\begin{array}{l}\text { Church activities covered via } \\
\text { news magazines }\end{array}$ & 8 & 16.33 \\
\hline 41. & $\begin{array}{l}\text { Church awareness created through } \\
\text { service clubs }\end{array}$ & 7 & 14.29 \\
\hline & $\begin{array}{l}\text { Assisted institutional PR directors by } \\
\text { involvement in institutional PR } \\
\text { planning committees }\end{array}$ & 7 & 14.29 \\
\hline
\end{tabular}




\begin{tabular}{|c|c|c|c|}
\hline \multirow{2}{*}{\multicolumn{2}{|c|}{ Activities }} & \multicolumn{2}{|c|}{$\begin{array}{l}\text { Conference } \\
\text { Communication } \\
\text { Directors }\end{array}$} \\
\hline & & No. & $\%$ \\
\hline 43. & $\begin{array}{l}\text { Assisted institutional PR directors } \\
\text { by helping with exhibits }\end{array}$ & 7 & 14.29 \\
\hline 44. & $\begin{array}{l}\text { Helped solve PR problems in an } \\
\text { institution }\end{array}$ & 7 & 14.29 \\
\hline 45. & $\begin{array}{l}\text { Promoted the appointment of } \\
\text { institutional PR directors }\end{array}$ & 6 & 12.24 \\
\hline 46. & $\begin{array}{l}\text { Church awareness created through } \\
\text { parades }\end{array}$ & 4 & 8.16 \\
\hline 47. & $\begin{array}{l}\text { Assisted institutional PR directors } \\
\text { by helping with parades }\end{array}$ & -- & --- \\
\hline
\end{tabular}




\section{TABLE 17}

ACTIVITIES ENGAGED IN OR ASSISTANCE GIVEN BY THE CONFERENCE COMMUNICATION DIRECTOR DURING A ONE MONTH PERIOD AS PERCEIVED BY CONFERENCE PRESIDENTS

\begin{tabular}{|c|c|c|c|}
\hline \multicolumn{2}{|r|}{ Activities } & \multicolumn{2}{|c|}{$\begin{array}{l}\text { Conference } \\
\text { Presidents }\end{array}$} \\
\hline & & No. & $\%$ \\
\hline 1. & Internal coverage via union paper & 37 & 94.87 \\
\hline & $\begin{array}{l}\text { Information, counsel, or advice given } \\
\text { local church communication secretary }\end{array}$ & 34 & 87.18 \\
\hline 3. & Distributed news releases & 33 & 84.62 \\
\hline 4. & Church leadership contacted by letter & 32 & 82.05 \\
\hline 5. & $\begin{array}{l}\text { Photographic coverage of local church } \\
\text { activities }\end{array}$ & 30 & 76.92 \\
\hline 6. & Office work in article or newswriting & 30 & 76.92 \\
\hline & $\begin{array}{l}\text { Church leadership contacted via } \\
\text { bulletins }\end{array}$ & 29 & 74.36 \\
\hline 8. & Church activities covered via newspapers & 29 & 74.36 \\
\hline & $\begin{array}{l}\text { Photographic coverage of conference- } \\
\text { wide activities }\end{array}$ & 28 & 71.79 \\
\hline 10. & Church leadership contacted by phone & 27 & 69.23 \\
\hline & $\begin{array}{l}\text { Information, counsel, or advice given } \\
\text { conference president }\end{array}$ & 24 & 61.54 \\
\hline & $\begin{array}{l}\text { Internal coverage via conference } \\
\text { church paper }\end{array}$ & 23 & 58.97 \\
\hline 13. & $\begin{array}{l}\text { Information, counsel, or advice } \\
\text { given conference departmental directors }\end{array}$ & 22 & 56.41 \\
\hline 14. & Office work on photo files & 22 & 56.41 \\
\hline & $\begin{array}{l}\text { Church leadership contacted by } \\
\text { personal visits }\end{array}$ & 22 & 56.41 \\
\hline 16. & Office work preparing PR reports & 21 & 53.85 \\
\hline & Distributed audio-visual materials & 19 & 48.72 \\
\hline 18. & Distributed brochures & 18 & 46.15 \\
\hline 19. & Helped solve conference-wide PR probiems & 17 & 43.59 \\
\hline 20. & $\begin{array}{l}\text { Promoted the appointment of local } \\
\text { church communication secretaries }\end{array}$ & 16 & 41.03 \\
\hline & Promoted tithes and offerings & 16 & 41.03 \\
\hline 22. & Church activities covered via radio & 75 & 38.46 \\
\hline
\end{tabular}


TABLE 17--Continued

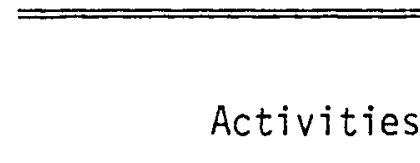

Conference

Presidents

No.

23. Helped solve PR problems in the conference office

24. Internal coverage via the Adventist Review

25. Helped solve PR problems in the local church

26. Photographic coverage of institutional activities

27. Office work on biographical files

28. Internal coverage via local church newsletters

29. Church activities covered via TV

30. Promoted fund-raising activities

31. Church awareness created through public service programs

32. Information, counsel, or advice given conference evangelist

33. Distributed advertisement materials 9

34. Church awareness created through exhibits 8

35. Conducted a workshop in PR

36. Assisted institutional PR directors by helping with exhibits

37. Church activities covered via news magazines

38. Church awareness created through parades

39. Church awareness created through service clubs

10.26

40. Conducted a workshop in journalism

41. Assisted institutional PR directors by involvement in institutional PR planning committees

42. Assisted institutional PR directors by assisting with joint churchinstitutional programs 
TABLE 17--Continued

\begin{tabular}{|c|c|c|c|}
\hline \multirow{2}{*}{\multicolumn{2}{|c|}{ Activities }} & \multicolumn{2}{|c|}{$\begin{array}{l}\text { Conference } \\
\text { Presidents }\end{array}$} \\
\hline & & No. & $\%$ \\
\hline 43. & $\begin{array}{l}\text { Helped solve PR problems in } \\
\text { an institution }\end{array}$ & 2 & 5.13 \\
\hline 44. & Conducted a workshop in photography & 2 & 5.13 \\
\hline 45 . & $\begin{array}{l}\text { Assisted institutional PR directors } \\
\text { by helping with parades }\end{array}$ & 1 & 2.56 \\
\hline 46. & Conducted a workshop in radio-TV & 1 & 2.56 \\
\hline & $\begin{array}{l}\text { Promoted the appointment of } \\
\text { institutional PR directors }\end{array}$ & -- & --- \\
\hline
\end{tabular}

"distribution of news releases" (84.62 percent, table 17).

Although there is a diversity of opinion among the three groups of respondents as to the activity given first place, there is a consensus of opinion on the second most engaged in activity of communication directors, namely "information, counsel, or advice given local church communication secretaries."

Even though the order varied among the three groups of respondents, "distribution of news releases" was seen by all groups as being one of the three activities receiving the highest response for this section of the survey.

However, on the other end of the percentage scale, all three groups of respondents consistently indicate the lack of involvement by the communication director in the various PR interests of denominational institutions. The reasons for this lack of involvement became more apparent. During a recent (spring 1981) hospital public relations workshop held at Andrews University and 
attended by the researcher. A "question was raised during the session concerning the working relationship between conference or union communication directors and Adventist hospital public relations staff. Most of those leading out in the workshop suggested that there was very little, if any, working relationship between the church's communication department (on any of the levels) and hospital PR staffs. One of the main reasons stressed by the visiting hospital PR instructors for this almost non-existant relationship was the sense of professionalism on the part of most hospital PR staffs as contrasted with the generally non-professional PR staff in most of the church's PR positions. Since those conducting the workshop were university professors and PR administrators, as well as guest speakers from Adventist Health System North, and the Kettering Medical Center's public relations department, the researcher felt their remarks were worth noting as possible reasons behind the general lack of interchange between conference communication directors and institutional PR directors as brought out in the survey.

In this same section of the survey, provision was made (see sample surveys in appendix $H$ ) for handwritten notations on additional activities that conference communication directors were involved in during a one month period as perceived by the respondents. Collectively (table 14 , column 6 ), this section shows relatively high percentages, for it includes in many instances more than one response per respondent (such as the 118.4 percent, table 14 , column 6). However, except for the quotes already mentioned, the importance of this section, according to the researcher, is not of 
great value. For reference or additional study the collective "other" list for this section is found in appendix $J$.

\section{The Primary Place of the Local Conference Communication Director in "Finishing" God's Work}

All of the respondents for this section of the survey were allowed to respond to any or all parts of the section as they so desired.

In a comparison of the respondents' perceptions of the primary place of the local conference communication director in "finishing" God's work (table 18 and figure 8), the majority of respondents (pastors, communication directors, and conference presidents) view the work of the conference communication director as being "indirect evangelism in terms of image-building." The highest percentages: are the pastors with 77.65 percent (table 18, column 1). Next were the conference communication directors with 69.39 percent (table 18, column 2), followed by the conference presidents with 66.67 percent (table 18, column 3). Al1 respondents were within an 11 percent range of each other.

The area having the next highest response was that view taken by the respondents who felt that the primary place of the local conference communication director in "finishing" God's work was evangelism in terms of "seed-sowing" (table 18). Again all three groups were relatively close to each other with little more than a 6 percent difference. The same pattern is seen here as with the responses given in support of the "image-building" section. However, it should be noted that the response percentages for 


\section{TABLE 18}

THE PRIMARY PLACE OF THE LOCAL CONFERENCE COMMUNICATION DIRECTOR IN "FINISHING" GOD'S WORK

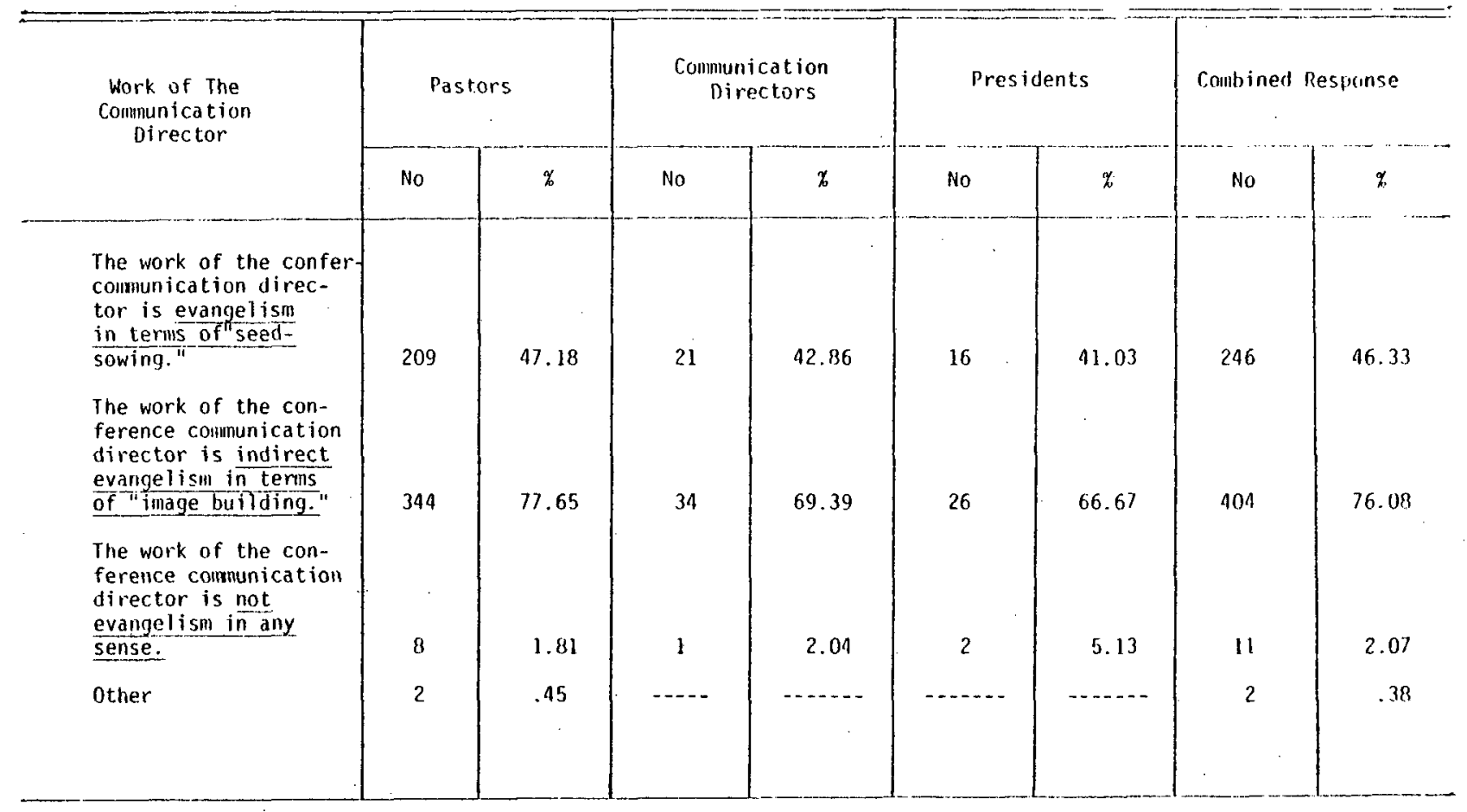




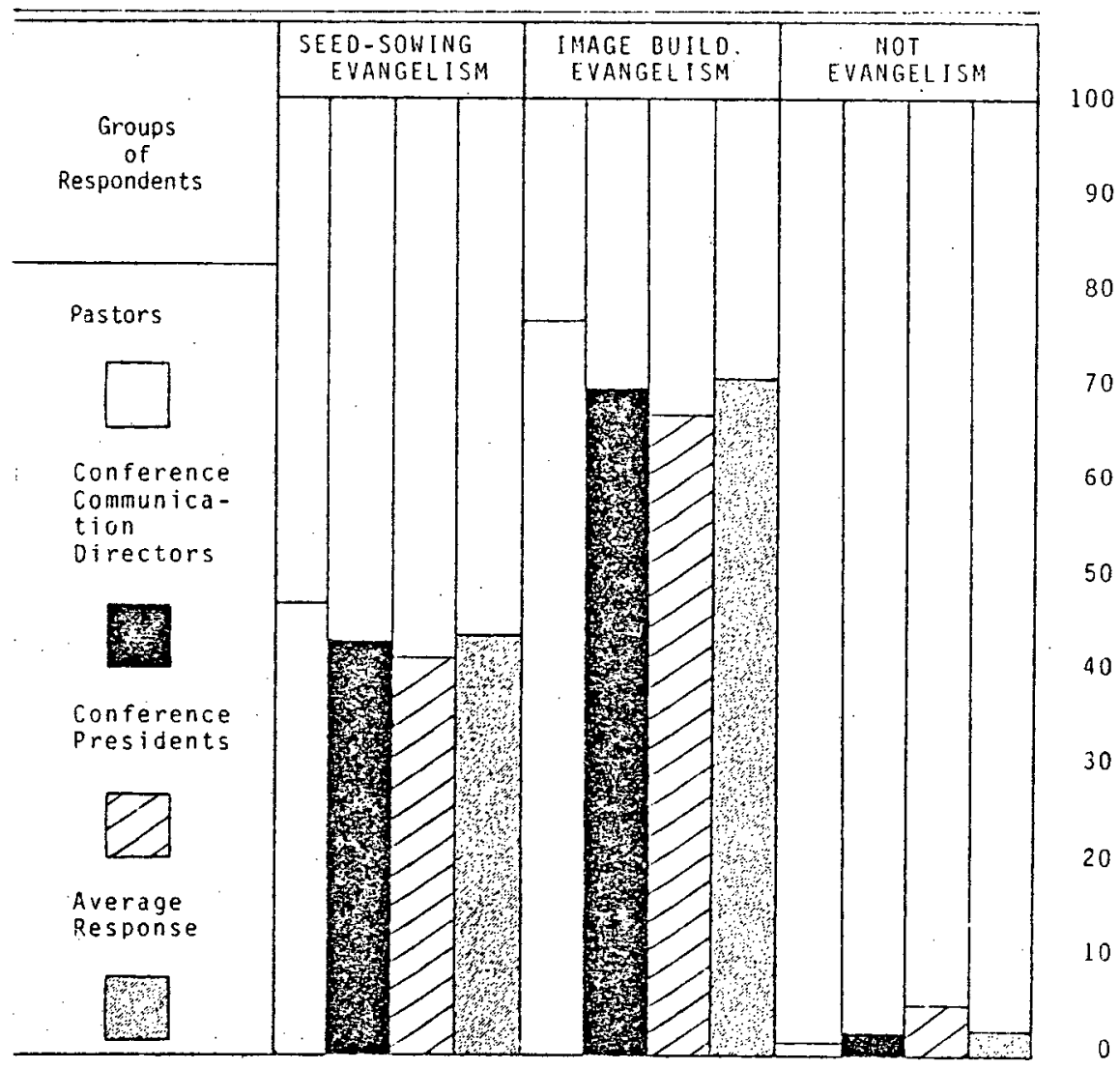

Fig. 8. Respondents' perceptions as to the primary place of the local Conference Communi cation Director in "finishing" God's work.

"seed-sowing" evangelism are considerably lower for all three groups of respondents than those given "image-building evangelism" (table 18 and figure 8). For instance, ministers give a 47.18 percent response to "seed-sowing evangelism".(table 18, column 1), a 30.47 percent drop from what they give to "image-building evangelism." Conference communication directors register a 42.86 percent response for "seed-sowing evangelism," 26.53 percent lower than their response to "image-building evangelism" (table 18, column 2). And conference presidents give 41.03 percent for "seed-sowing evangelism" 
(table 18, column 3), a drop of 25.64 percent from their response to "image-building evangelism."

In the final category of responses it is interesting to note that a few in each group of respondents felt that the work of the conference communication director was "not evangelism in any sense" (table 18). A higher percentage of conference presidents indicated this (5.13 percent, table 18, column 3) than either communication directors (2.04 percent, table 18, column 2) or pastors (1.81 percent, table 18, column 1).

Of all the respondents only two, both of them pastors, presented suggestions for this section of the survey (.45 percent, table 18, column 1). One pastor felt he could not agree with any of the survey statements suggested, but made no alternative suggestions. The other pastor said he did not know how to relate to these statements on the local level, so he left them blank.

When the respondents' perceptions concerning the primary place of the conference communication director in "finishing" God's work are examined according to various age groups (tables 19 to 21 , and figures 9 to 13), the following results become evident.

For pastors in the 20 to 29 age group, "seed-sowing" and "image-building" evangelism are viewed as of almost equal importance. This is indicated by a less than 1 percent difference in the responses given these two categories $(4.97$ percent for "seed-sowing," and 5.87 percent for "image-building" evangelism, table 19 and figure 9). A11 of the other pastors age groups view "image-building" evangelism as their preference over "seed-sowing" evangelism (figures 10 through 13). However, it should be noted that pastors ages 30 to 39 are in 
TABLE 19

PASTORS' RESPONSE TO THE PRIMARY PLACE OF THE CONFERENCE COMMUNICATION DIRECTOR. IN "FINISHING" GOD'S WORK

\begin{tabular}{|c|c|c|c|c|c|c|c|c|c|c|c|c|c|c|c|}
\hline \multirow{3}{*}{$\begin{array}{l}\text { Work of the } \\
\text { Communication } \\
\text { Director }\end{array}$} & \multirow{2}{*}{\multicolumn{2}{|c|}{$20-29$}} & $A$ & $c$ & C $\quad 0$ & $r$ & $d$ & $i n$ & g & $t$ & 0 & $A \quad g$ & $\dot{e}$ & & \\
\hline & & & \multicolumn{3}{|c|}{$30-39$} & & \multicolumn{3}{|c|}{$40-49$} & \multicolumn{4}{|c|}{$50-59$} & 60 & plus \\
\hline & No & $\%$ & No & & $\%$ & & & No & $\%$ & & No & $\%$ & & No & $\%$ \\
\hline
\end{tabular}

The work of the

conference com-

munication direc-

tor is evangelism

in terms of "seed-

sowing."

The work of the conference communication director

is indirect evangetism in terms of "image building."

The work of the conference communication director is not evangelism in any sense.

3




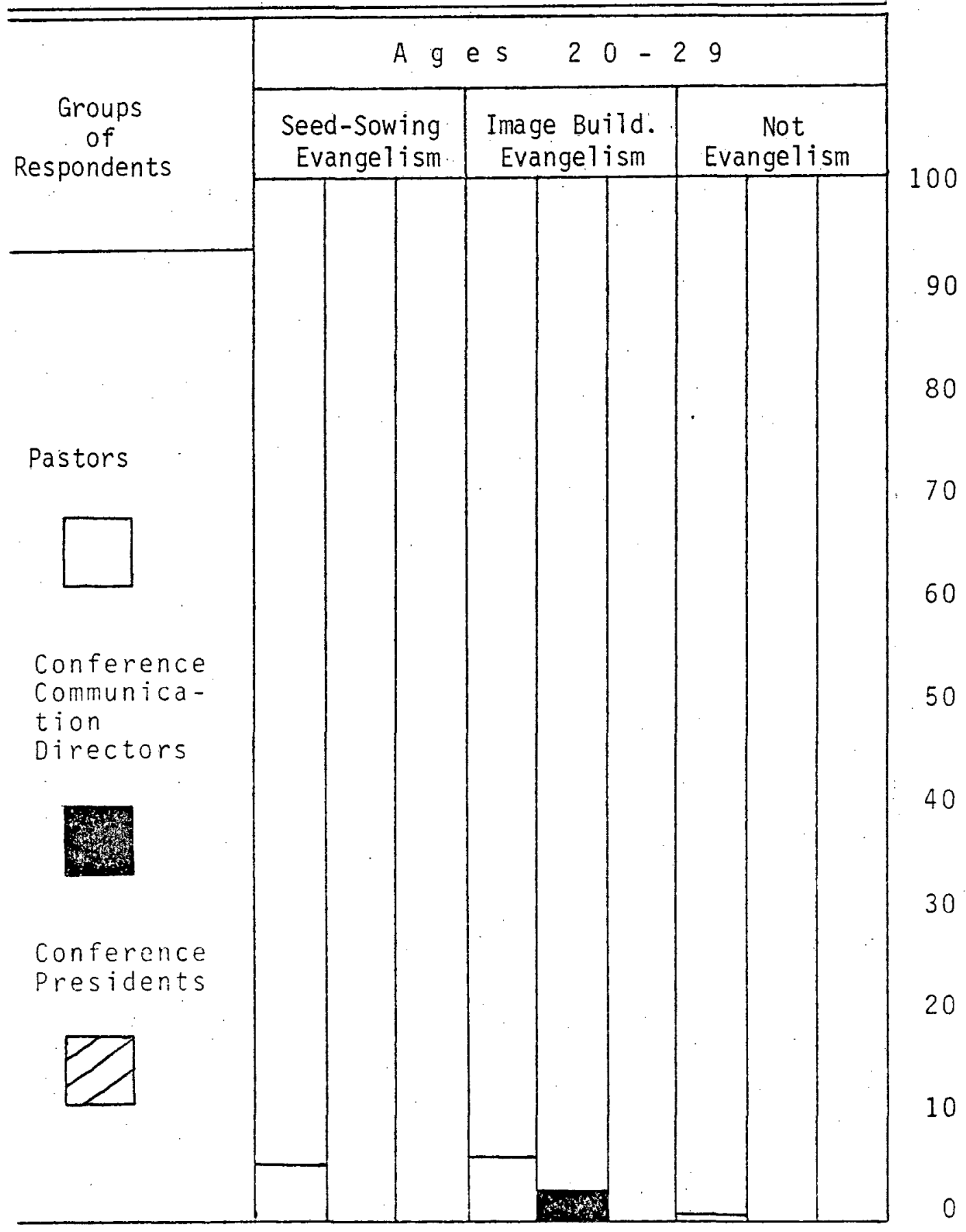

Fig. 9. Respondents' perceptions as to the primary place of the Conference Communication Director in "finishing" God's work. 
closer harmony with pastors ages 20 - 29 (table 19, column 2, and figure 10) than they are with those in the older age groups. Their responses to "image-building" evangelism (21.67 percent, table 19, column 2, and figure 10) and "seed-sowing" evangelism (15.58 percent, table 19, column 2 and figure 10) do not show the large percentage differences as those seen in the responses of older pastors. Pastors ages, 40 to 49,50 to 59 , and 60 plus, show almost twice as great a response to "image-building" evangelism as they do to "seed-sowing" evangelism (table 19 and figures 11 to 13 ).

With the exception of the 20 to 29 and 50 to 59 age groups, all of the conference communication directors perceive the work of the conference communication director as being first of all evangelism in terms of "image-building," and secondly as evangelism in terms of "seed-sowing" (figures 9 to 13). The six conference communication directors--ages 50 to 59--were more in harmony with the perceptions of the pastors in the 20 to 29 age group. They see the conference communication director's work as being both "image-building" evangelism (12.24 percent, table 20 and figure 12), and "seedsowing" evangelism (12.24 percent, table 20 and figure 12). It appears that in their minds these two aspects of evangelism are equal. The one conference communication director who was in the 20 to 29 age bracket indicated "image-building" evangelism (2.04 percent, table 20 and figure 9) as his preference.

Communication directors, ages 30 to 39 (figure 10), like pastors in the same age group, are closer in their views on "imagebuilding" evangelism and "seed-sowing" evangelism to pastors ages, 20 to 29 than they are to older communication directors. This can 


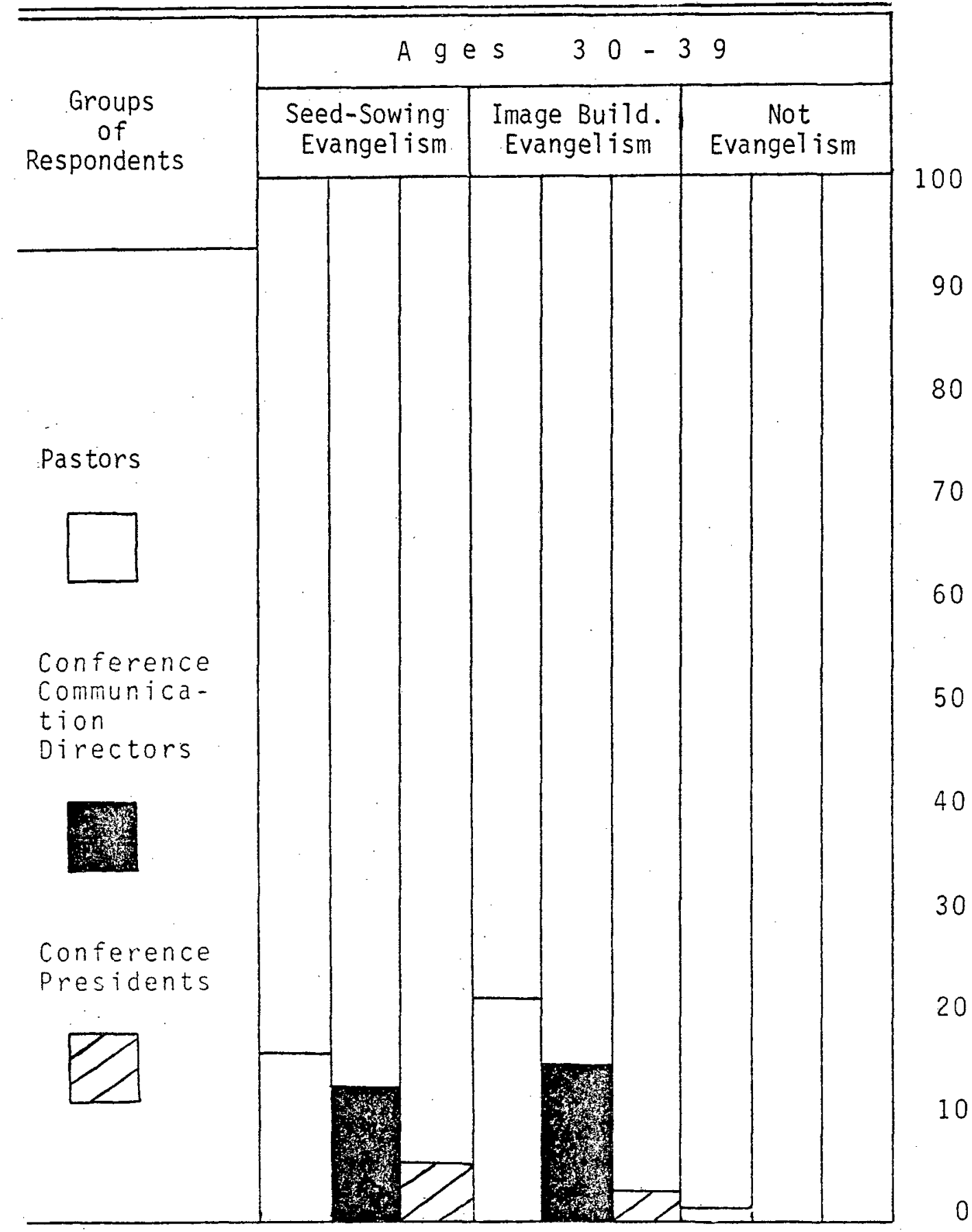

Fig. 10. Respondents' perceptions as to the primary place of the Conference Communication Director in "finishing" God's work. 


\section{TABLE 20}

CONFERENCE COMMUNICATION DIRECTORS' RESPONSE TO THE PRIMARY

PLACE OF THE LOCAL CONFERENCE COMMUNICATION DIRECTOR

IN "FINISHING" GOD'S WORK

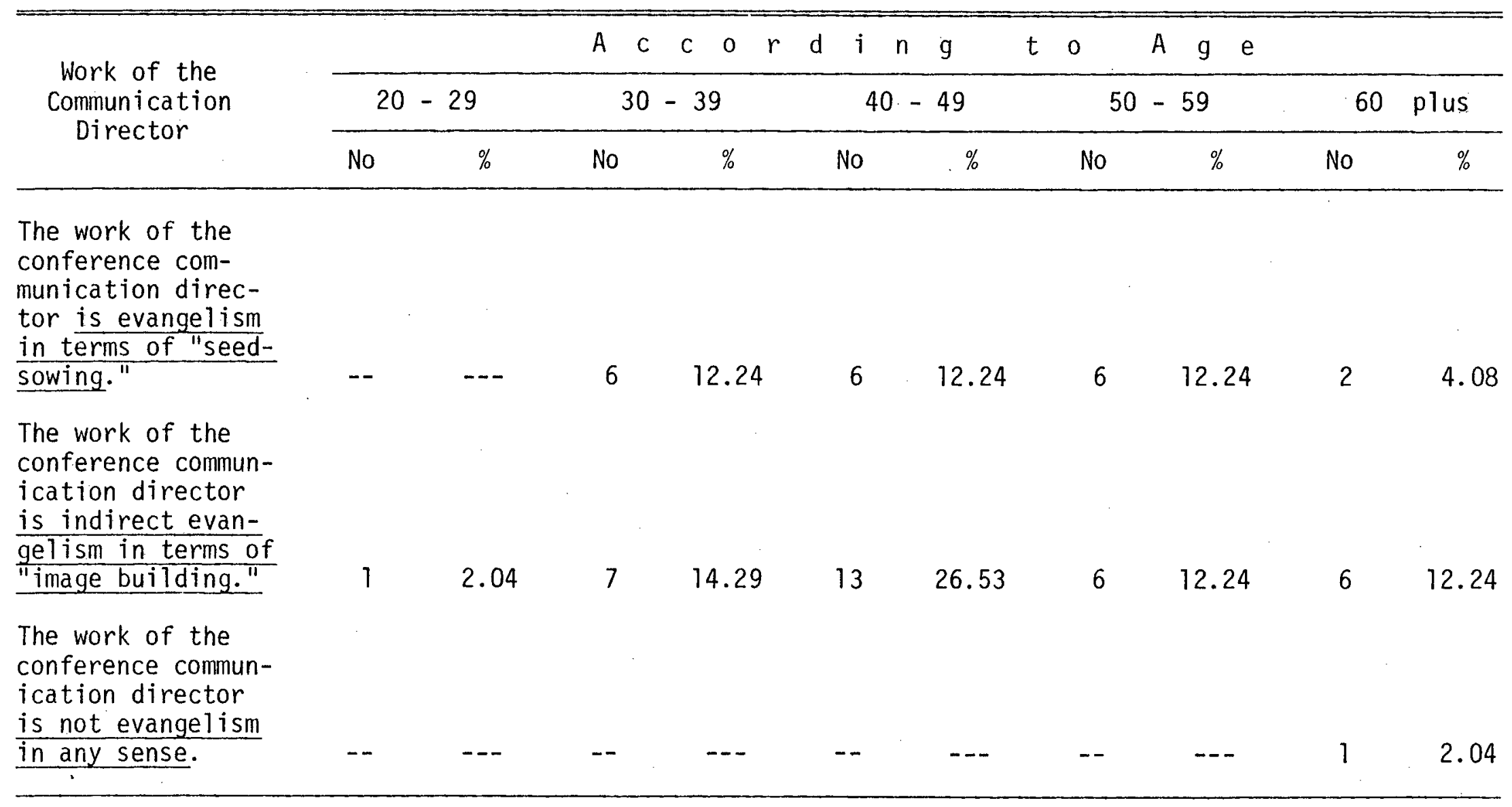




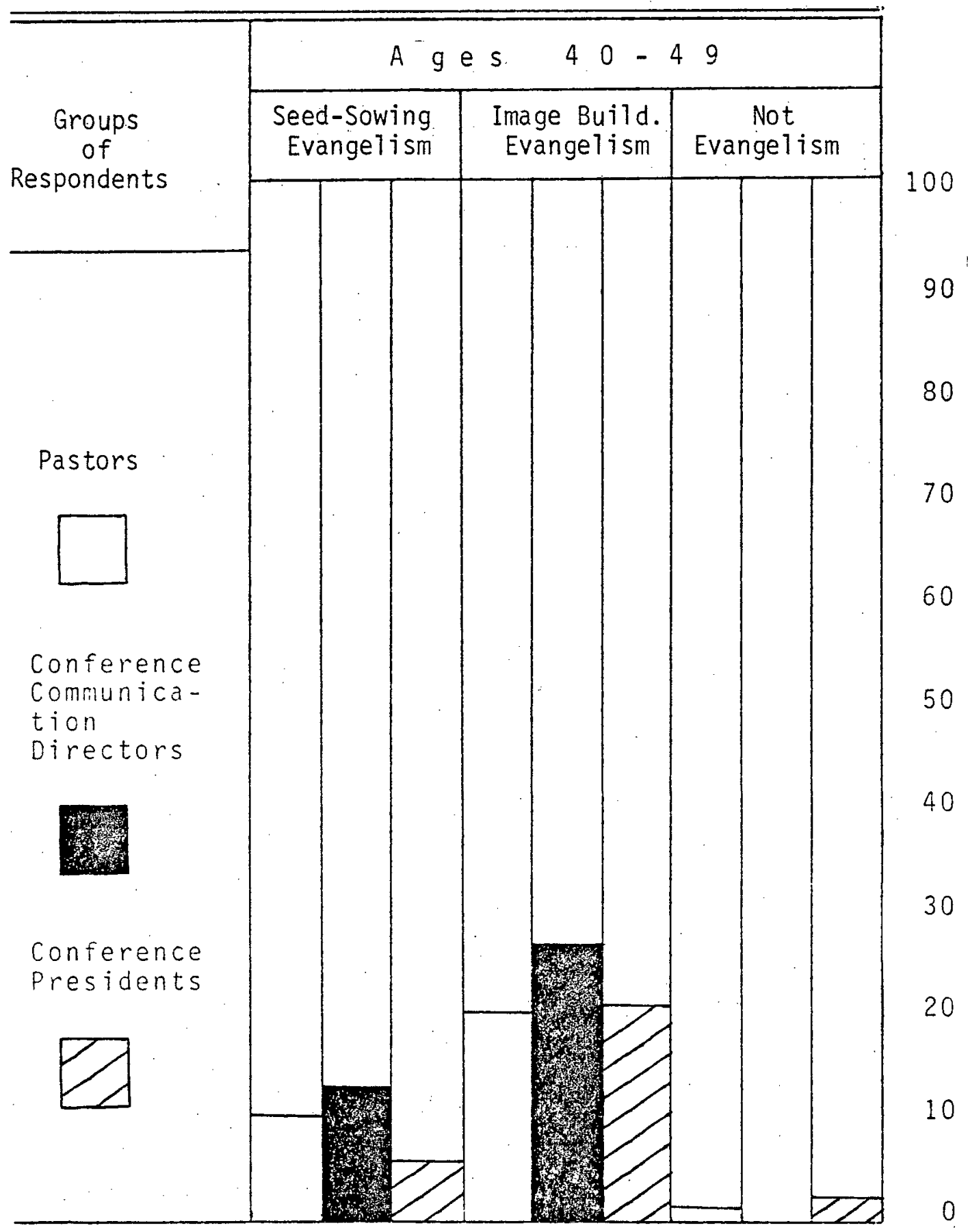

Fig. 11. Respondents' perceptions as to the primary place of the Conference Communication Director in "finishing" God's work. 


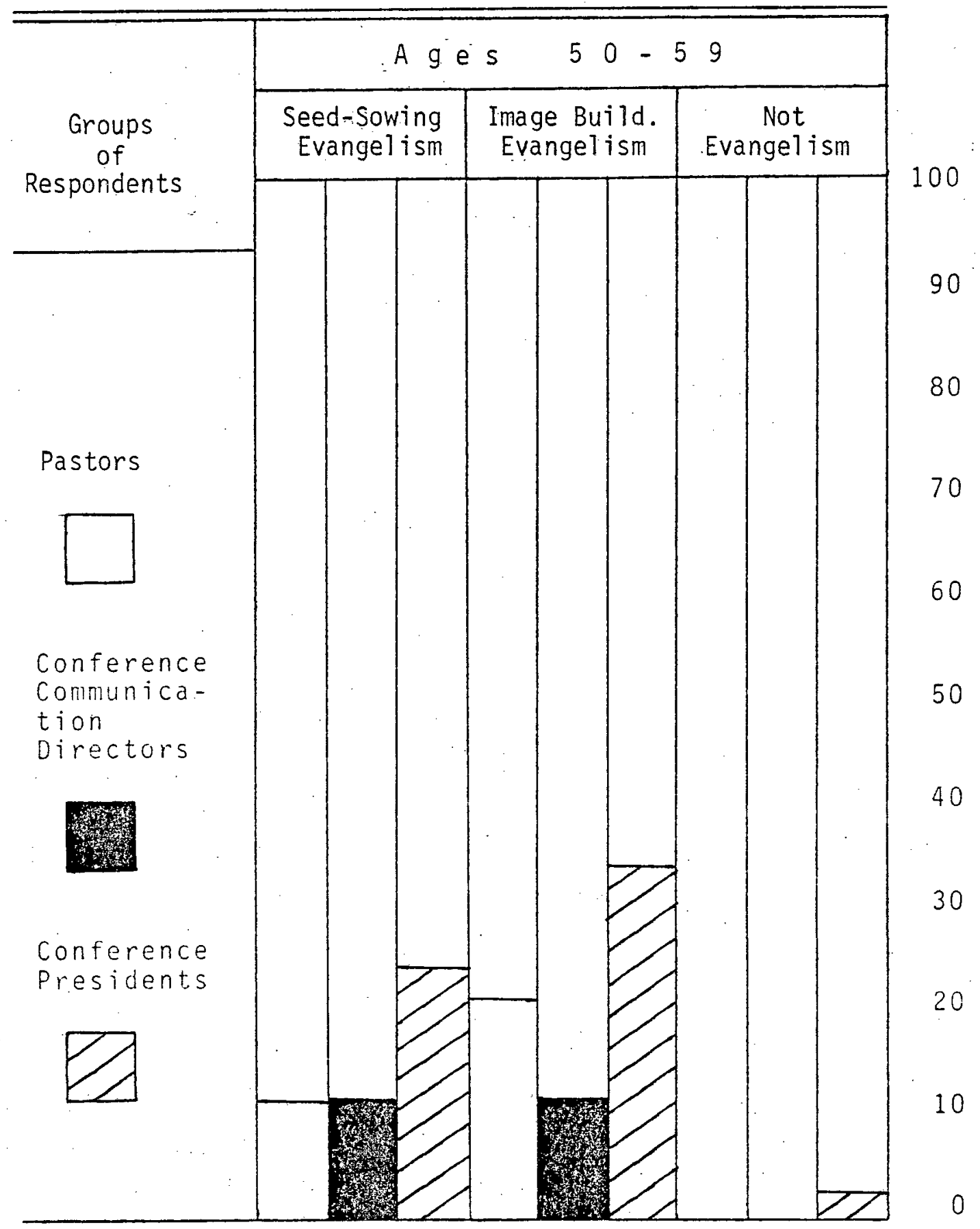

Fig. 12. Respondents' perceptions as to the primary place of the Conference Communication Director in "finishing" God's work. 
be seen by the relatively small difference between the responses they give to "image-building" evangelism (14.29 percent, table 20, column 2, and figure .10) and "seed-sowing" evangelism (12.24 percent, table 20, column 2, and figure 10).

On the other hand, conference communication directors, sages 40 to 49 and 60 plus, show a response more than twice as great (for the 60 plus age group-- -3 times as great) for "image-building" evangelism (table 20, figures 11 and 13) as they do for "seedsowing" evangelism (table 20, figures 11 and 13), a pattern very similar to that followed by pastors ages 40 to 49,50 to 59 , and 60 plus.

When they are divided up into various age groups, conference presidents seem to show a greater variety of responses to this section of the survey than do pastors or communication directors.

For ages 20 to 29 there are no responses given by conference presidents, which could possibly indicate the absence of conference presidents in this age group.

Conference presidents, ages 30 to 39 , show an interesting response to this section of the survey. They give "seed-sowing" evangelism (5.13 percent, table 21, column 2, and figure 10) their preference over "image-building" evangelism (2.56 percent, table 21, column 2, and figure 10). This is the onty age bracket within any group of respondents that shows this preference reversal to the predominate trends already discussed in this section of the survey. However, it should be noted that one of the strongest responses by any of the groups of respondents in favor of "image-building" evangelism as opposed to "seed-sowing evangelism is also given by 


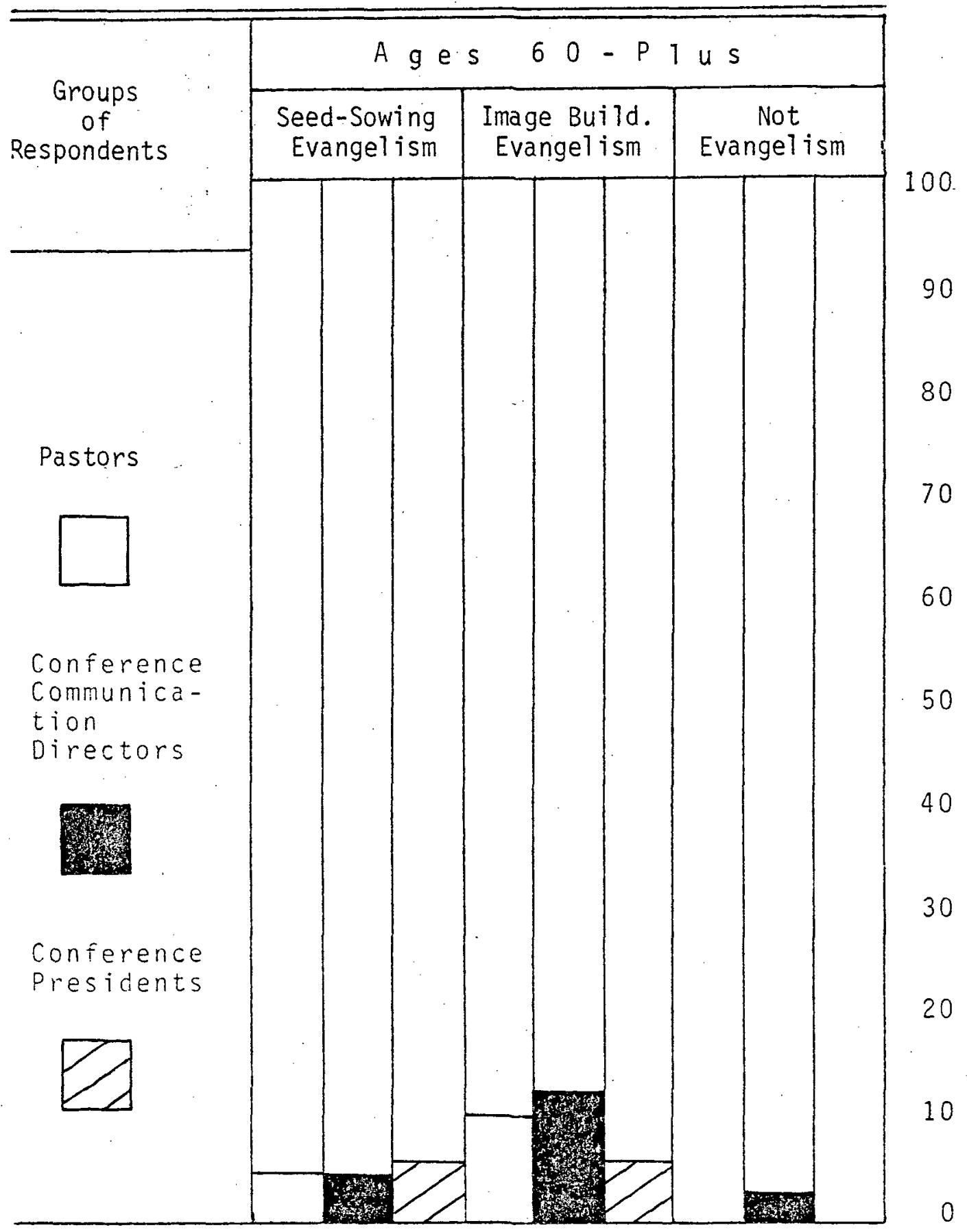

Fig. 13. Respondents' perceptions as to the primary place of the Conference Communication Director in "finishing" God's work. 
TABLE 21

CONFERENCE PRESIDENTS' RESPONSE TO THE PRIMARY PLACE

OF THE LOCAL CONFERENCE COMMUNICATION DIRECTOR

IN "FINISHING" GOD'S WORK

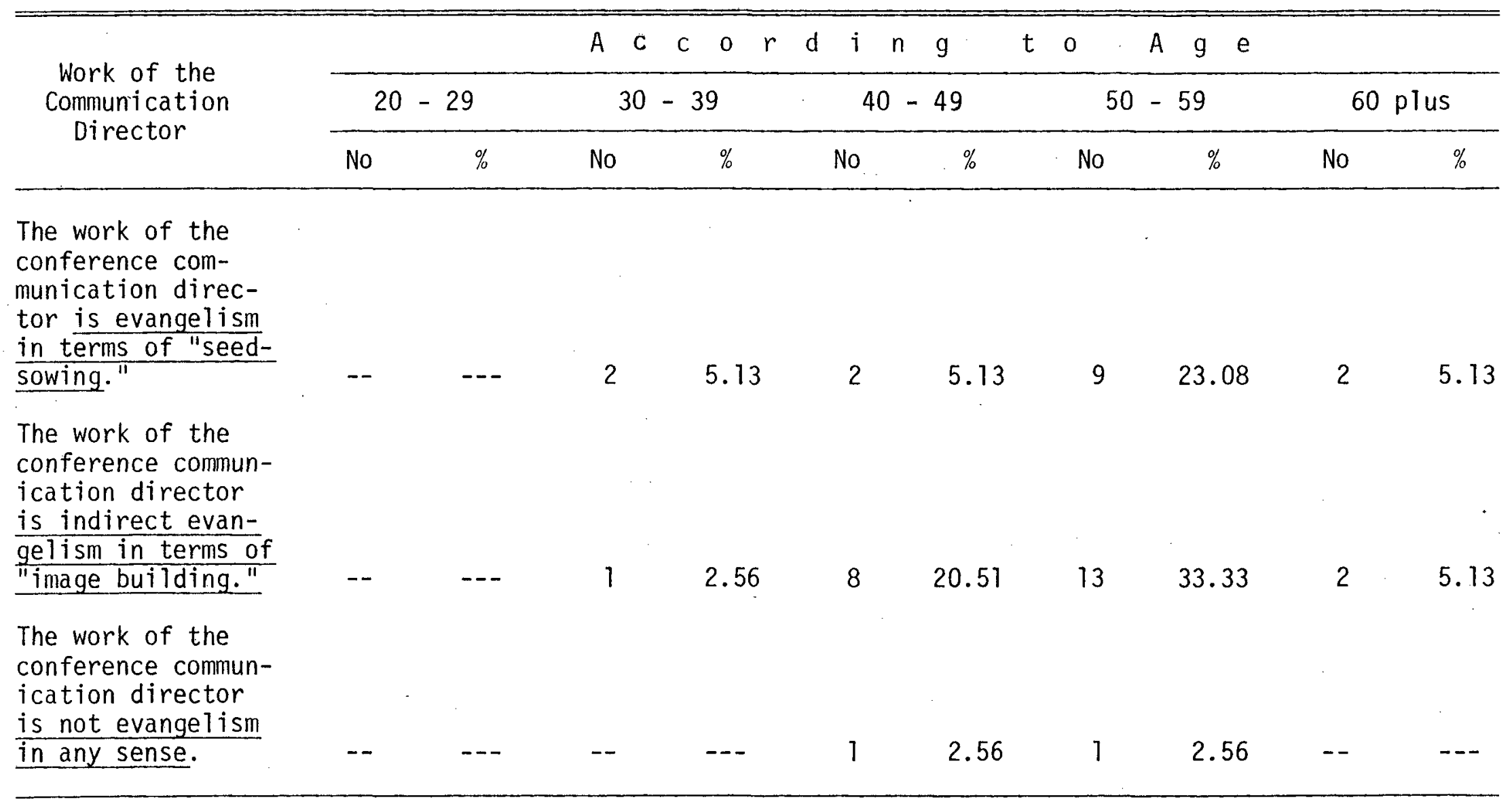


conference presidents. The next age group (40 to 49) of conference presidents show a preference four times greater for "image-building" evangelism (20.51 percent, table 21, column 3, and figure 11) than they do for "seed-sowing" evangelism (5.13 percent, table 21, column 3 , and figure 11). By this response, conference presidents appear to indicate an agreement with the other respondents (pastors and communication directors, ages 40 to 49 ) in their preference for "image-building" evangelism over "seed-sowing" evangelism (tables 19 to 21 , and figure 11 ).

Although the percentage difference is not as great, conference presidents, ages 50 to 59, again indicate their preference for "image-building" evangelism (33.33 percent, table 21, column 4, and figure 12) over "seed-sowing" evangelism (23.08 percent, table 21, column 4 , and figure 12).

For ages 60 plus, conference presidents view "seed-sowing" evangelism (5.13 percent, table 21, column 5, and figure 13), and "image-building" evangelism (5.13 percent, table 21 , column 5, and figure 13), as of equal importance. In this respect they are in agreement with the conference communication directors, ages 50 to 59 (table 20 and figure 12), and very close to that of the pastors, ages 20 to 29 (table 19 and figure 9).

Although the responses are quite low (a11 three below 1 percent), three groups of pastors (ages 20 to 29, 30 to 39, and 40 to 49 ) indicate that according to their view the work of the conference communication director is not evangelistic in any sense (table 19 and figure 9 to 11). One conference communication director in the 60 plus group, gave the same "not evangelistic in 
any sense" response (2.04 percent, table 20 and figure 13), and so did two conference presidents, ages 40 to 49 , and 50 to $59(2.56$ percent, table 21 and figures 11 and 12).

$$
\frac{\frac{\text { Professional or Specialized Training }}{\text { Needed by Conference Communication }}}{\text { Directors }}
$$

An overview of figures 14 and 15 concerning the professional or specialized training needed by communication directors seems to indicate that communication directors themselves feel a stronger need for additional professional or specialized training than suggested by either pastors or conference presidents. In fact, the responses of communication directors were highest in fifteen out of the nineteen categories (tables 22 and 23, and figures 14 and 15).

These results are illustrated by one communication director who said: "I guess I'd like a lot more opportunities for professional growth."

And another stated:

I don't claim expertise in any area, and certainly feel the need for improvement in al.1 areas. . . I I have checked these, not because of a lack of experience in these areas, but because of the need to sharpen these skills which are essential to church communication.

Pastors are highest in only two categories. That is, more of them (27.54 percent, table 23, column 4, and figure 15, column 4) indicated that the conference communication director needs additional training in "soul-winning methods" than did either conference presidents or communication directors themselves. Their second highest response shows the conference communication director's need 
TABLE 22

PROFESSIONAL OR SPECIALIZED TRAINING NEEDED BY CONFERENCE COMMUNICATION DIRECTORS AS

SUGGESTED BY THE FOLLOWING RESPONDENTS

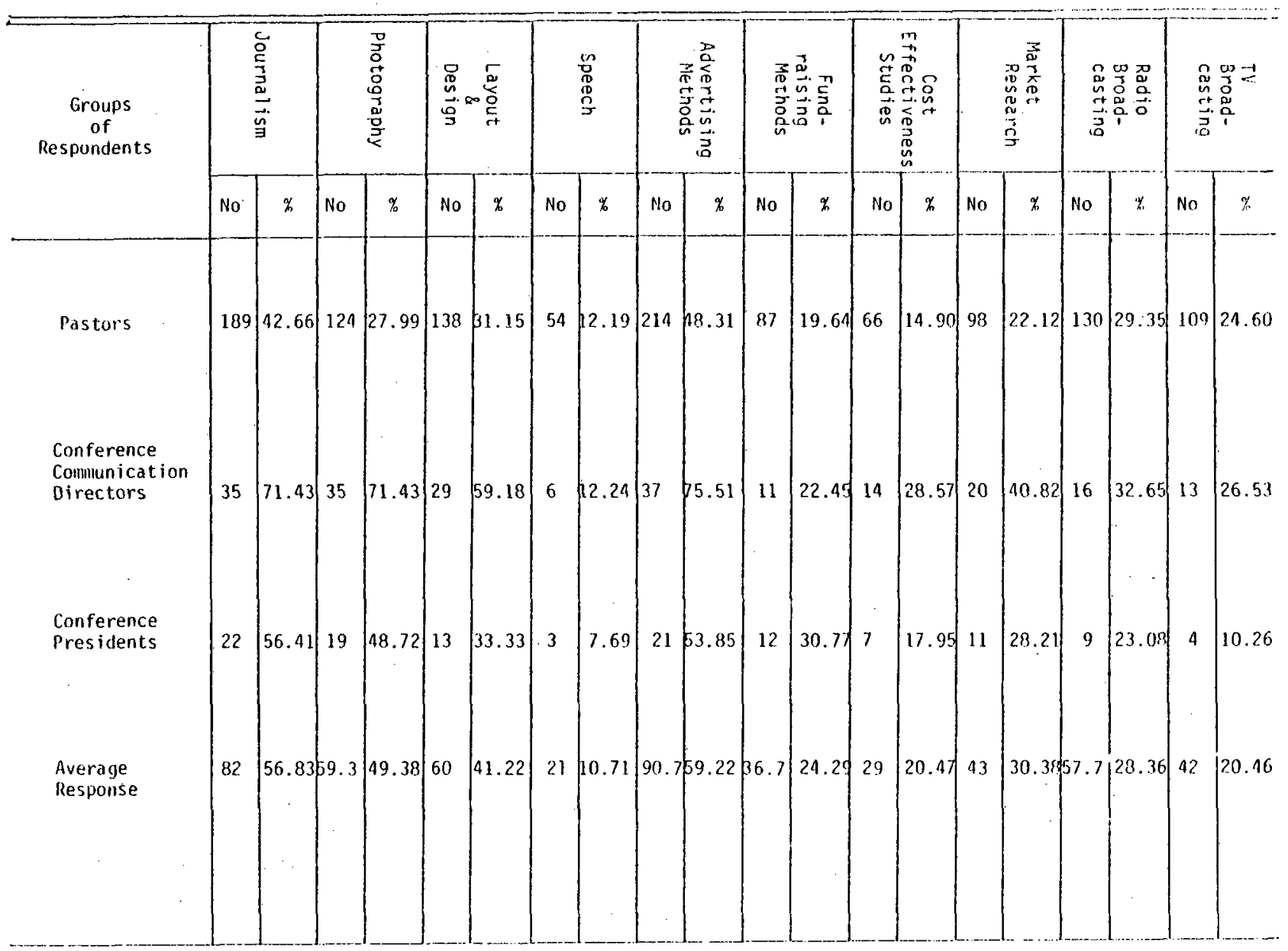


TABLE 23

PROFESSIONAL OR SPECIALIZED TRAINING NEEDED BY CONFERENCE COMMUNICATION DIRECTORS AS SUGGESTED BY THE FOLLOWING RESPONDENTS

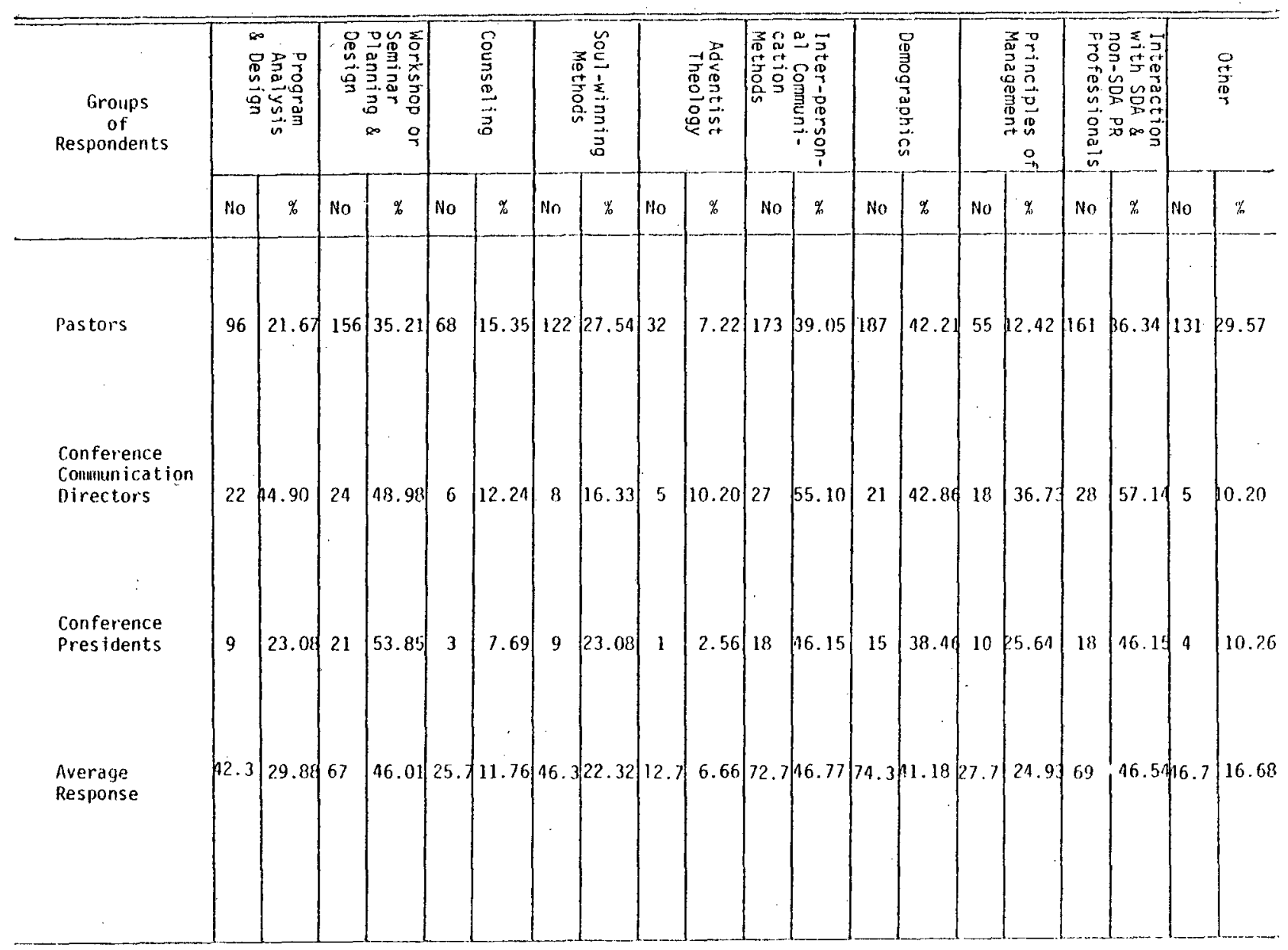




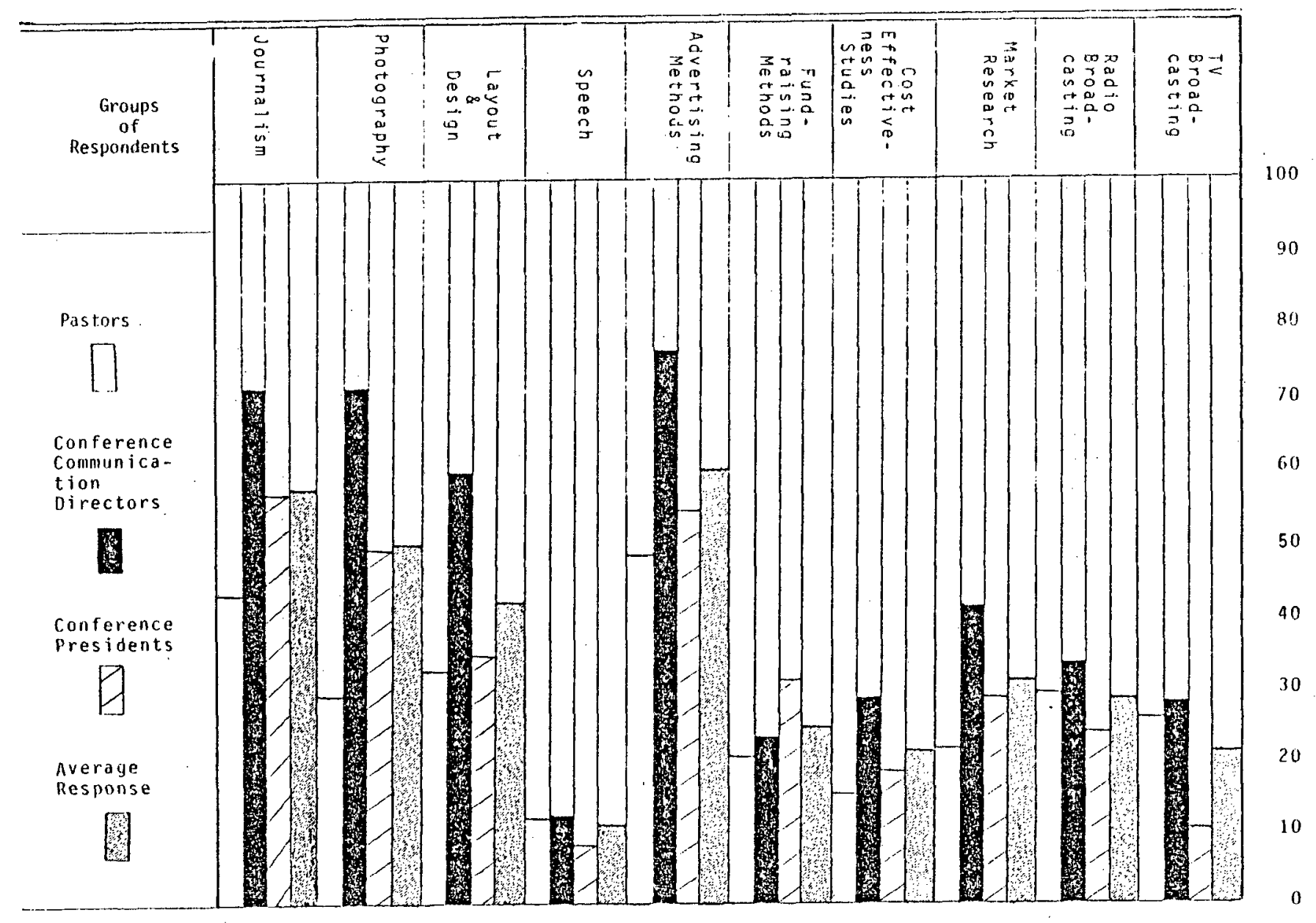

Fig. 14. Professional or specialized training needed by Conference Communication Directors as suggested by the following respondents. 


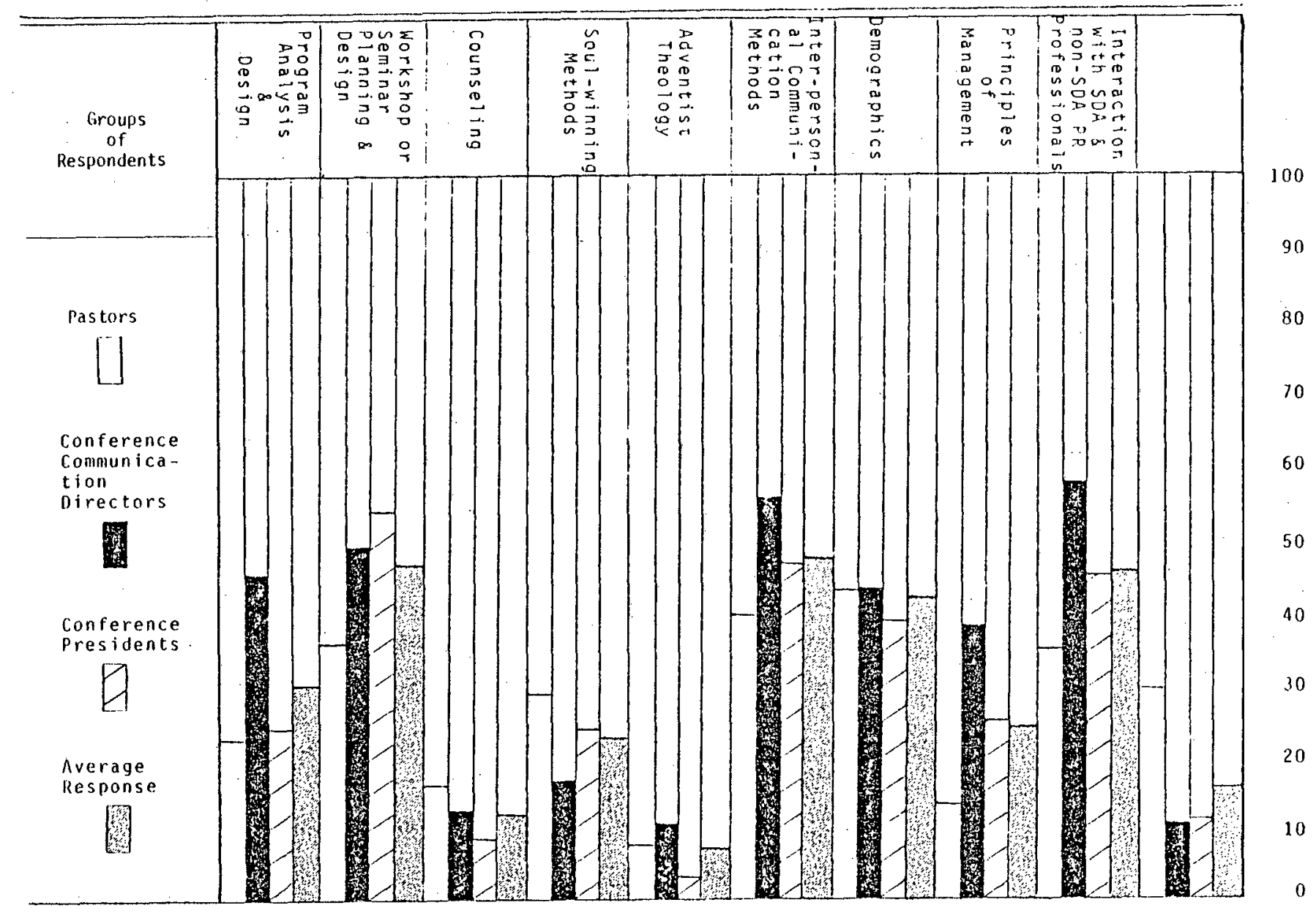

$\dot{\omega}$

Fig. 15. Professional or specialized trining needed by Conference Communication Directors as suggested by the following respondents. 
for additional training in the "counseling" field (15.35 percent, table 23, column 3 , and figure 15 , column 3$)$.

Similarly, conference presidents were highest in two categories. They indicated a need for communication directors to have additional training in "workshop or seminar planning and design" (53.85 percent, table 23, column 2, and figure 15, column 2) and in "fund-raising methods" (30.77 percent, table 22, column 6, and figure 14, column 6). Apparently these presidents see a need for the communication director's obtaining additional expertise in those areas which are considered more important from an administrator's viewpoint than from a pastor's or communication. director's

The three highest need categories of all the respondents, are those indicated by the communication directors themselves. These are areas where the communication directors felt a need for additional training in "advertising methods" (75.51 percent, table 22, column 5, and figure 14, column 5), "photography" (71.43 percent, table 22, column 2, and figure 14, column 2), and "journalism" (71.43 percent, table 22, column 1, and figure 14, column 1).

The three highest need categories suggested by conference presidents for conference communication directors are in the areas of "journalism". (56.41 percent, table 22, column 1, and figure 14, column 1), "advertising methods" (53.85 percent, table 22, column 5, and figure 14, column 5), and "workshop or seminar planning and design" (53.85 percent, table 23, column 2, and figure 15, column 2). Concerning this section of the survey one conference president remarked; 
Our conference director does not feel he is professional in any way in the field of communication. It has been a secondary role in his departmental activities. He is happy that the union is handling many of his duties. He would receive benefit from any of the training mentioned in this survey.

Another president said: "I feel he is one of the best in the business. I don't believe schooling would help him, as he does a top job in all areas."

Pastors see the following three categories as being important for the conference communication directors to receive additional training in: "advertising methods" (48.31 percent, table 22, column 5, and figure 14, column 5), "journalism" (42.66 percent, table 22, column 1, and figure 14, column 1), and "demographics" (42.21 percent, table 23, column 7, and figure 15, column 7).

One pastor typical of others made the following remarks about his conference communication director:

To the best of my knowledge, he has not had any professional training in any area of PR, therefore his capacity to he $1 p$ is limited. Unfortunately, despite all the emphasis on competent PR within the denomination, conferences'still put in untrained individuals as heads of PR departments and worse yet, load them down with other responsibilities, such as stewardship, or what have you. Usually they put in a minister of some large church who is "climbing upwards" mostly to his level of incompetence. As it stands, the local conference PR departments are very mediocre and by and large a big joke. Why not trim them off and save the budget.

Even though the order and percentages vary, al1 three groups of respondents give priority to "advertising methods" and "journalism" as important areas for additional training of conference communication directors.

Tables 24 through 26 give in descending order of importance the suggested professional or specialized training needed by conference communication directors as perceived by pastors, conference 
PROFESSIONAL OR SPECIALIZED TRAINING NEEDED BY

CONFERENCE COMMUNICATION DIRECTORS AS SUGGESTED BY PASTORS

\begin{tabular}{lcc}
\hline & \multicolumn{2}{c}{ päs t o r s } \\
\cline { 2 - 3 } & No. & $\%$ \\
\hline 1. Advertising methods & 214 & 48.31 \\
2. Journalism & 189 & 42.66 \\
3. Demographics & 187 & 42.21 \\
4. Inter-personal communication methods & 173 & 39.05 \\
5. Interaction with SDA and non-SDA & & \\
6R professionals & 161 & 36.34 \\
6. Workshop or seminar planning and & & \\
7. design & 156 & 35.21 \\
8. Rayout and design & 138 & 31.15 \\
9. Photography & 130 & 29.35 \\
10. Soul-winning methods & 124 & 27.99 \\
11. TV broadcasting & 122 & 27.54 \\
12. Market research & 109 & 24.60 \\
13. Program analysis and design & 98 & 22.12 \\
14. Fund-raising methods & 96 & 21.67 \\
15. Counseling & 87 & 19.64 \\
16. Cost effectiveness studies & 68 & 15.35 \\
17. Principles of management & 66 & 14.90 \\
18. Speech & 55 & 12.42 \\
19. Adventist theology & 54 & 12.19 \\
\hline
\end{tabular}


TABLE 25

PROFESSIONAL OR SPECIALIZED TRAINING NEEDED BY CONFERENCE COMMUNICATION DIRECTORS AS SUGGESTED BY CONFERENCE COMMUNICATION DIRECTORS

\begin{tabular}{llc}
\hline & & \multicolumn{2}{c}{$\begin{array}{c}\text { Conference } \\
\text { Communication } \\
\text { Directors }\end{array}$} \\
\cline { 2 - 3 } & No. & $\%$ \\
\hline 1. Advertising methods & 37 & 75.51 \\
2. Journalism & 35 & 71.43 \\
3. Photography & 35 & 71.43 \\
4. Layout and design & 29 & 59.18 \\
5. Interaction with SDA and non-SDA & & \\
6. PR professionals & 28 & 57.14 \\
6. Inter-personal communication methods & 27 & 55.10 \\
7. Workshop or seminar planning and & & \\
8. design & 24 & 48.98 \\
9. Demographics & 22 & 44.90 \\
10. Market research & 21 & 42.86 \\
11. Principles of management & 20 & 40.82 \\
12. Radio broadcasting & 18 & 36.73 \\
13. Cost effectiveness studies & 16 & 32.65 \\
14. TV broadcasting & 14 & 28.57 \\
15. Fund-raising methods & 13 & 26.53 \\
16. Soul-winning methods & 11 & 22.45 \\
17. Speech & 8 & 16.33 \\
18. Counseling & 6 & 12.24 \\
19. Adventist theology & 5 & 12.24 \\
\hline
\end{tabular}


TABLE 26

PROFESSIONAL OR SPECIALIZED TRAINING NEEDED BY CONFERENCE COMMUNICATION DIRECTORS AS SUGGESTED BY

\section{CONFERENCE PRESIDENTS}

\begin{tabular}{llc}
\hline \hline & \multicolumn{2}{c}{$\begin{array}{c}\text { Conference } \\
\text { Presidents }\end{array}$} \\
\cline { 2 - 3 } & No. & $\%$ \\
\hline 1. Journalism & 22 & 56.41 \\
2. Workshop or seminar planning and & & \\
design & 21 & 53.85 \\
3. Advertising methods & 21 & 53.85 \\
4. Photography & 19 & 48.72 \\
5. Inter-personal communication methods & 18 & 46.15 \\
6. Interaction with SDA and non-SDA & & \\
7. PR professionals & 18 & 46.15 \\
8. Lemographics & 15 & 38.46 \\
9. Fund-raising methods & 13 & 33.33 \\
10. Market research & 12 & 30.77 \\
11. Principles of management & 11 & 28.21 \\
12. Radio broadcasting & 10 & 25.64 \\
13. Program analysis and design & 9 & 23.08 \\
14. Soul-winning methods & 9 & 23.08 \\
15. Cost effectiveness studies & 9 & 23.08 \\
16. TV broadcasting & 7 & 17.95 \\
17. Speech & 4 & 10.26 \\
18. Counseling & 3 & 7.69 \\
19. Adventist theology & 3 & 7.69 \\
\hline
\end{tabular}


communication directors, and conference presidents.

Although there were some variations expressed by the respondents under the section marked "other" (figure 15 and table 24), the researcher does not fee] that these remarks in any way alter the overall trends seen in this section of the survey. However, for reference purposes these additional notes have been listed in appendix $K$.

$$
\frac{\text { The Relative Importance of the }}{\frac{\text { Work of the Local Conference }}{\text { Communication Director }}}
$$

As indicated by the subtitle, this section of the survey deals with the respondents' perceptions to the importance of the work of the conference communication director as it relates to other departments of the conference (table 27 and figure 16). The scale used by the researcher for this section ascends from an extreme view of the department as being "optional" on the one hand to a "most important" view on the other.

None of the communication directors and only two of the conference presidents (5.12 percent, table 27, column 3, and figure 16, column 1) perceive the communication department as being "optional" on the local conference level. However, sixty-nine of the pastors surveyed (15.57 percent, table 27 , column 1, and figure 16, column 1), a relatively large group, do see the department as being "optional" on the local level.

The responses given by pastors (17.8 percent, table 27, column 1, and figure 16, column 2) and conference presidents (17.95 percent, table 27 , column 3, and figure 16, column 2) 
TABLE 27

RELATIVE IMPORTANCE OF THE WORK OF THE CONFERENCE

COMMUNICATION DIRECTOR

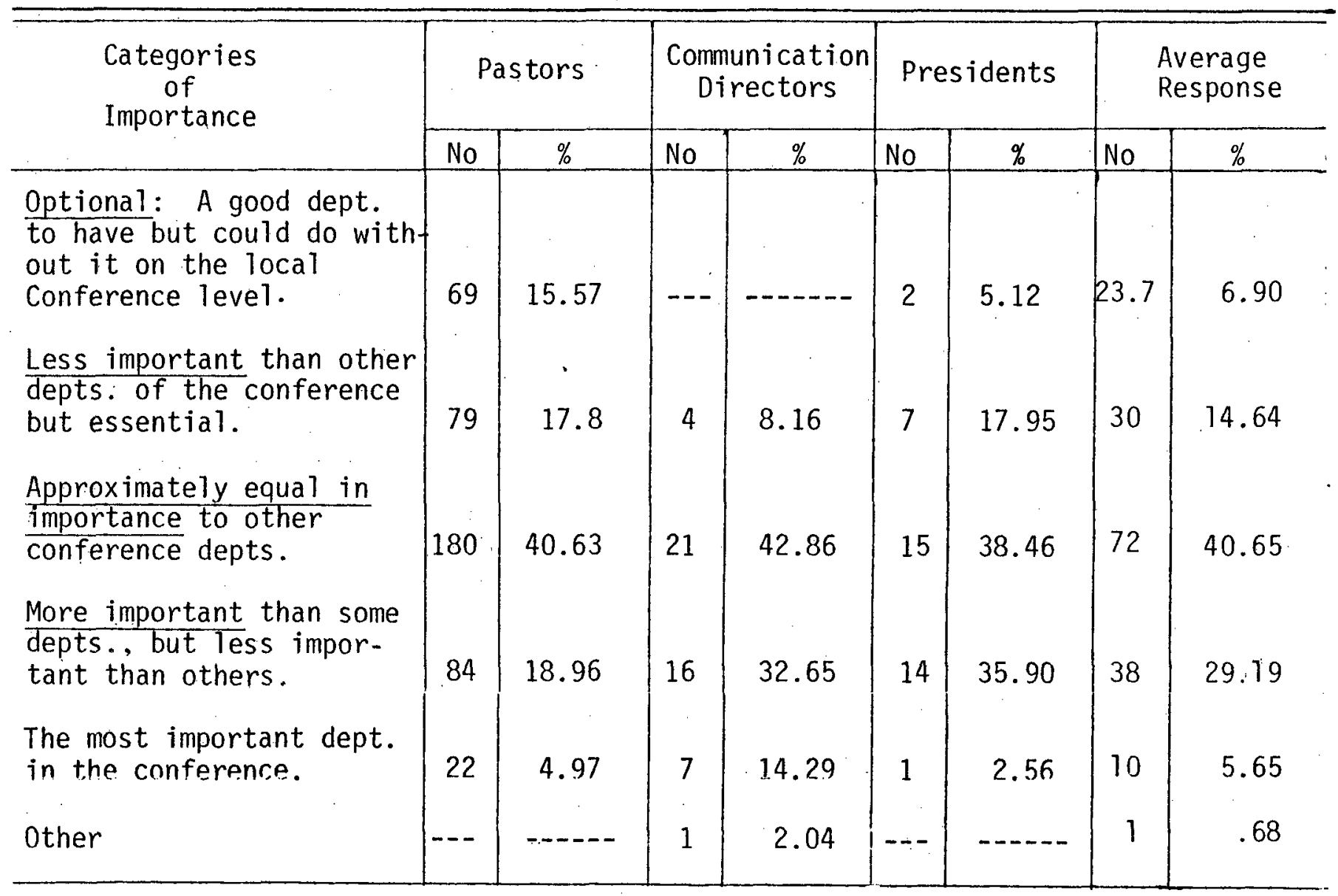




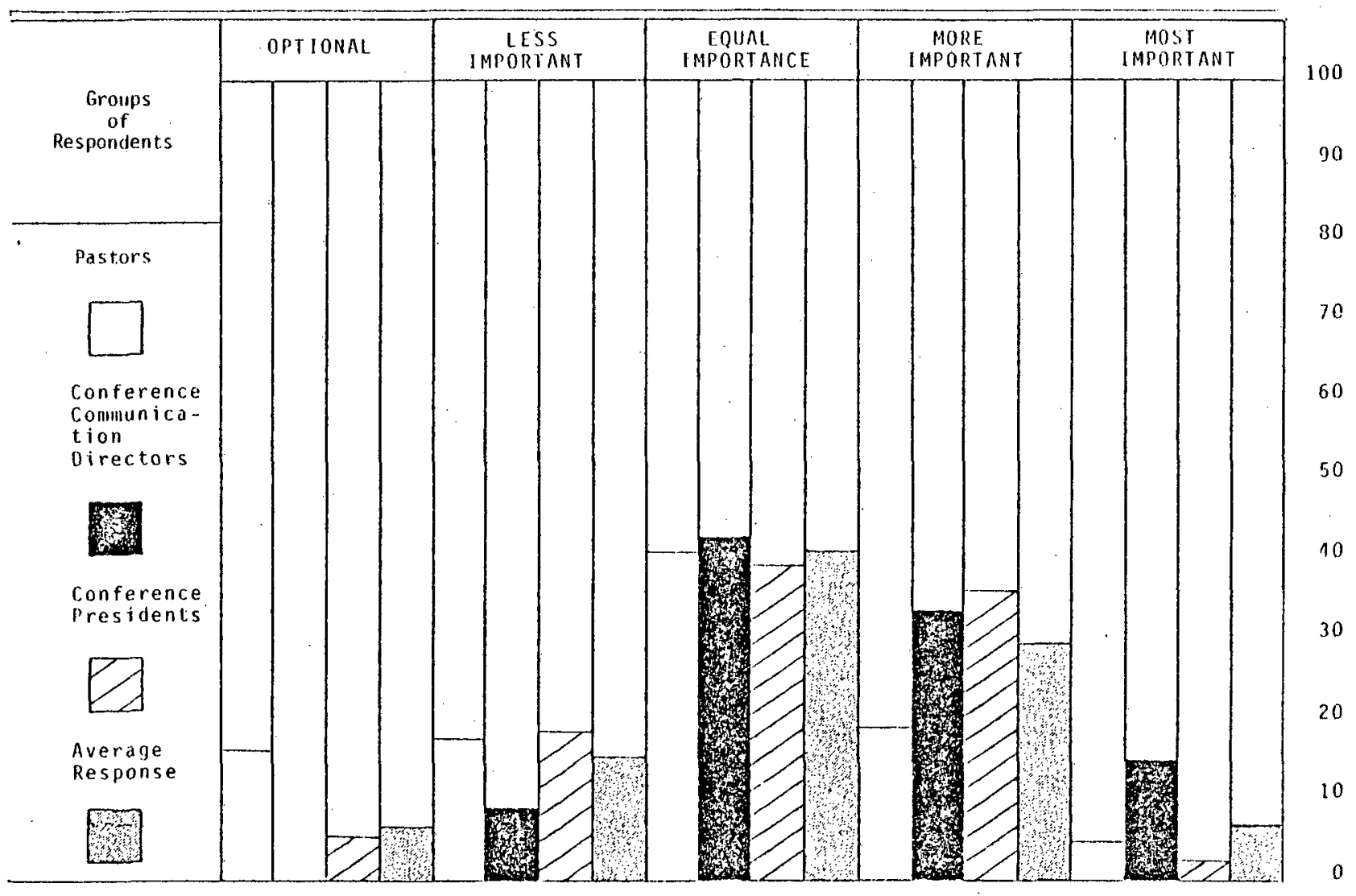

$\vec{f}$

Fig. 16. Respondents' perceptions as to the relative importance of the work of the Conference Communication Director. 
indicating their view of the communication department as being "less important than other departments of the conference but essential". are very close to each other percentagewise (less than .2 percent difference). Communication directors register an 8.16 percent response for this section (table 27, column 2), less than half the response percentage of pastors and conference presidents. However, when the responses of all three groups are viewed together, especially in light of the responses given to the "optional" column, a somewhat interesting picture develops.

For instance, when added together, the pastors' responses to the "optional" and "less important" columns for this section of the survey total 33.37 percent (table 27, column 1), and the conference presidents,' total for these same two columns equals 23.07 percent (table 27, column 3). Since both the "optional" and "less important" columns are at the lower end of the value scale used to judge the importance of the conference communication department as compared to other conference departments, these totals (pastors-33.37 percent, and presidents--23.07 percent) seem to indicate possible questions in the minds of a relatively large group of respondents: as to the credibility of the communication department on the local conference level.

This is also true of the responses made by several communication directors: Even though none of the communication directors checked the "optional" column, there were four or 8.16 percent (table 27, column 2, and figure 16, column 2) who viewed the conference communication department as being "less important" than other conference departments. The percentage here is low but is 
of worth noting since the responses were made by the special group under study. The ir responses, no matter how insignificant, do have an important relationship to the overall effectiveness of the communication department on the local level.

The highest response for pastors (40:63 percent, table 27, column 1, and figure 16 , column 3 ), communication directors (42.86 percent, table 27, column 2, and figure 16, column 3), and conference presidents $(38.46$ percent, table 27 , column 3 , and figure 16 , column 3) was the view taken by all three groups of the communication department being "approximately equal in importance to other conference departments."

As to the communication department being "more important than some departments, but less important than others, "conference presidents gave the highest response (35.90 percent, table 27, column 3 , and figure 16, column 4), then communication directors (32.65 percent, table 27, column 2, and figure 16, column 4), and finally pastors (18.96 percent, table 27, column 2, and figure 16, column 4). It is interesting again to note that conference presidents give a higher response for this section (35.90 percent, table 27) than the communication directors themselves (32.65 percent, table 27). This view taken by the presidents could have some bearing on. how the department functions on the local level.

As is perhaps understandable, the highest response to the communication department being viewed as "the most important department in the conference". (even though it is not very high percentagewise) is given by the communication directors (14.29 percent, table 27, column 2, and figure 16, column 5). Next are the pastors 
(4.97 percent, table 27, column 1, and figure 16, column 5), and last, the conference presidents (2.56 percent, table 27, column 3 , and figure 16, column 5). It should be noted, however, that even though communication directors show the highest response percentage here, a number of the directors and pastors qualified their responses for this section by suggesting that the conference communication department was not now the most important department in the conference but could be the most important if it were operated as it should be.

A typical comment for this section of the survey which brings out this thought is given by one pastor who remarked: "To communicate the gospel is our most important work. If rightly done this department would be the most important."

A second pastor states: "We have never really gotten the vision in the local conference of the vital importance of this area in the Lord's work."

Another pastor gives as his reason for checking the "optional"section: "This is based on my experience of this office as it is run in this conference. I could use help but I find that most communication directors are not as knowledgeable in communication as I am."

An overview of figure 16 reveals some similarities of agreement among the three groups surveyed. In general, a11 three give a low response to the "optional" section and gradually climb through "less important". to a high in the "equal importance" section. From this point, there is a gradual tapering off through "more important" to the lowest response which is found in the "most important" section. 
When different age groups (tables 28 to 30 and figures 17 to 21) are examined concerning their response to the relative importance of the work of the conference communication director, a number of interesting patterns and pattern variations become evident.

A11 of the ministers, ages 20 to 29,30 to 39,50 to 59 , and 60 plus (figures $17,18,20$, and 21) follow the same response patterns observed in figure 16. They begin with a low response on the negative end of the scale (optional) gradually rise through the next category (less important), reach a peak in the center of the scale (equal importance), and finally taper off through the next category (more important), reaching a low on the positive end of the scale (most important). The only exceptions here are for pastors, ages 20 to 29 (figure 17), who give no response to the last section (most important), and pastors 60 plus who give the same response to "optional" as they do to the "less important" category (figure 21). This same pattern is observed in the responses of communication directors, ages 30 to 39 and 40 to 49 (figures 18 and 19 ), and conference presidents 40 to 49 , (figure 19) with the exception that neither group gives a response to the "optiona1" category.

From the responses indicated by pastors, communication directors, and conference presidents in the age groups just mentioned, it would appear that they have taken a "middle of the road" approach concerning the value of the communication department on the local level. For them the communication department is "approximately equal in importance to other conference departments." 


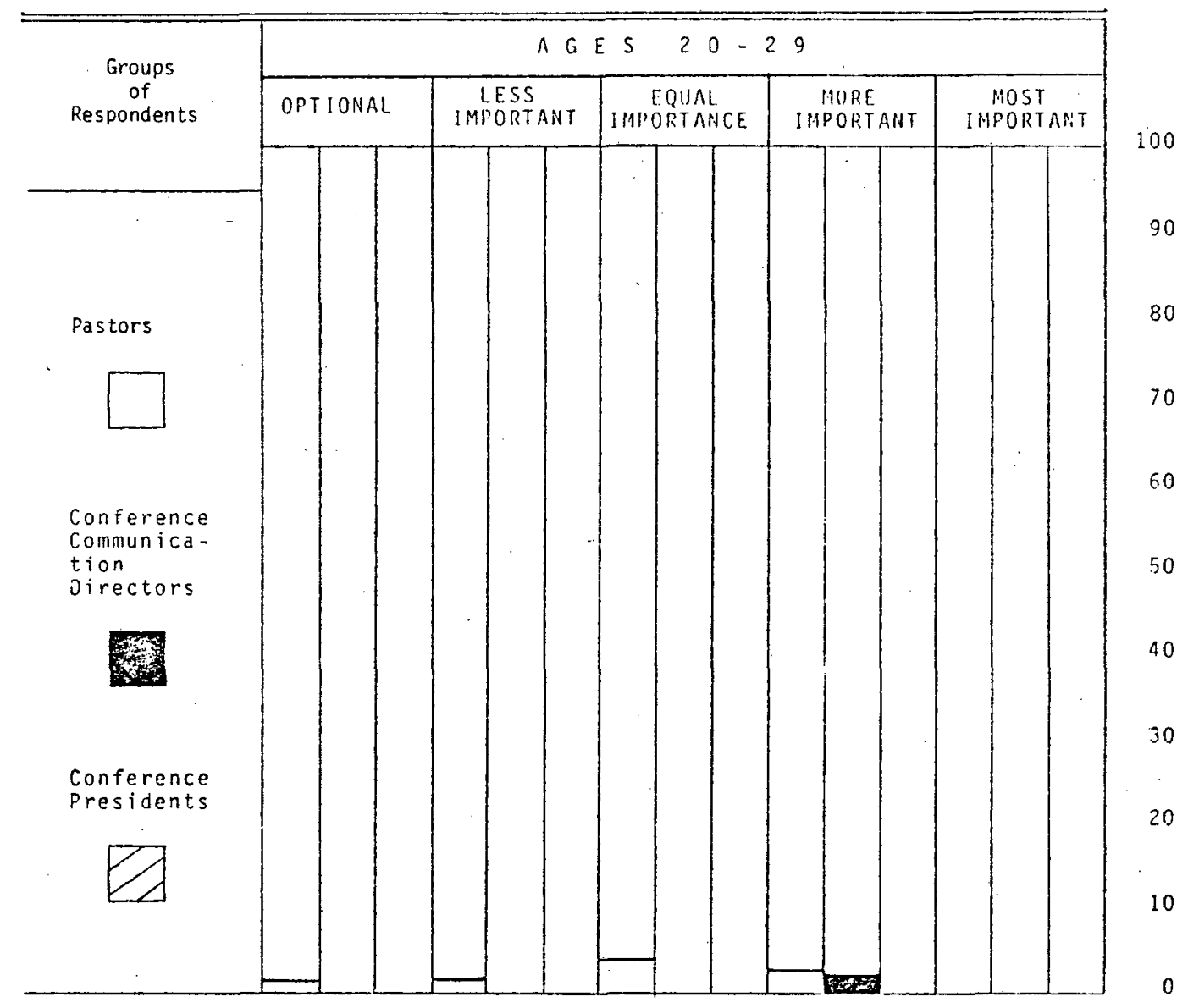

Fig. 17. Respondents' perceptions as to the relative importance of the work of the Conference Communication Director. 


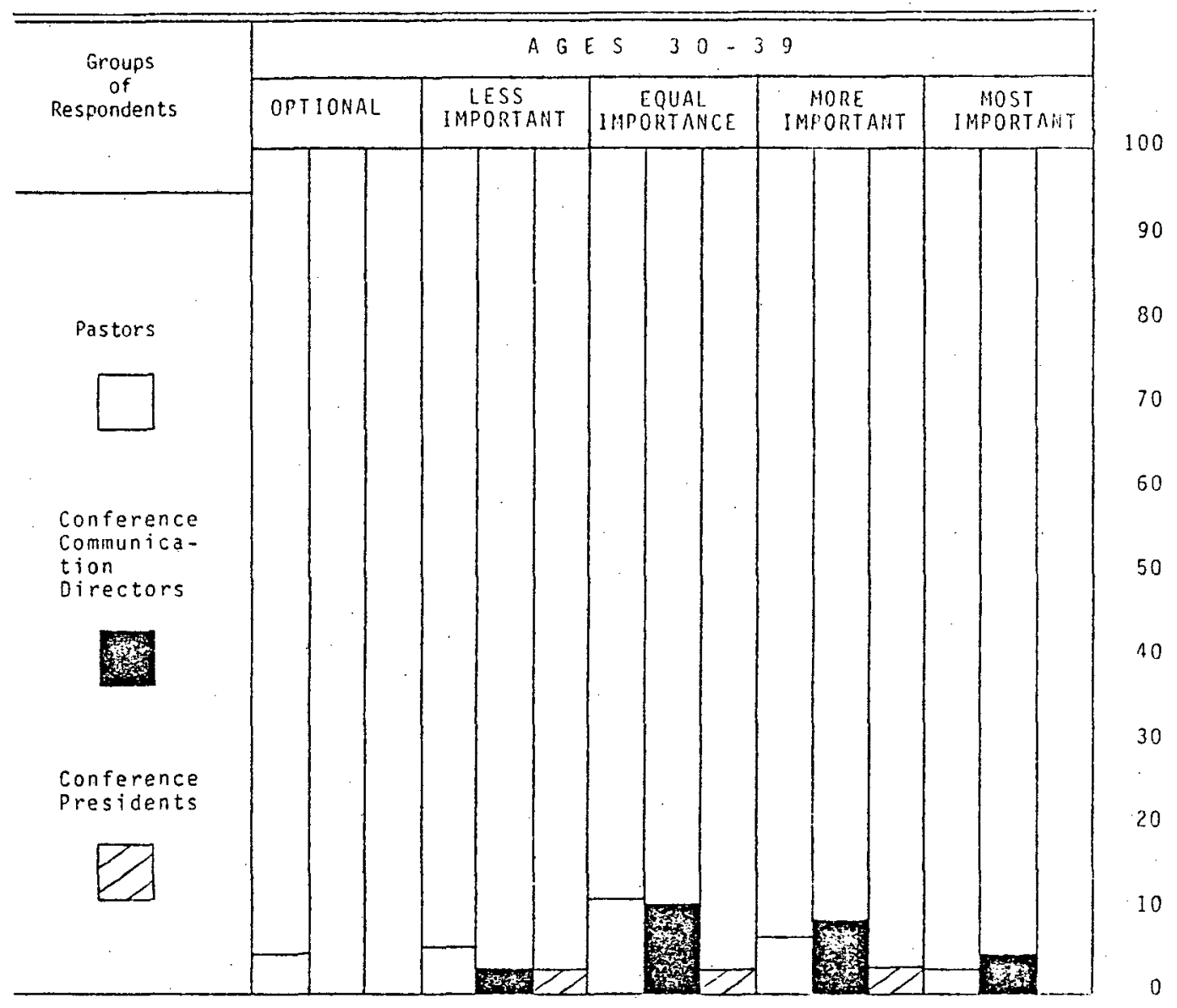

Fig. 18. Respondents' perceptions as to the relative importance of the work of the Conference Communication Director. 


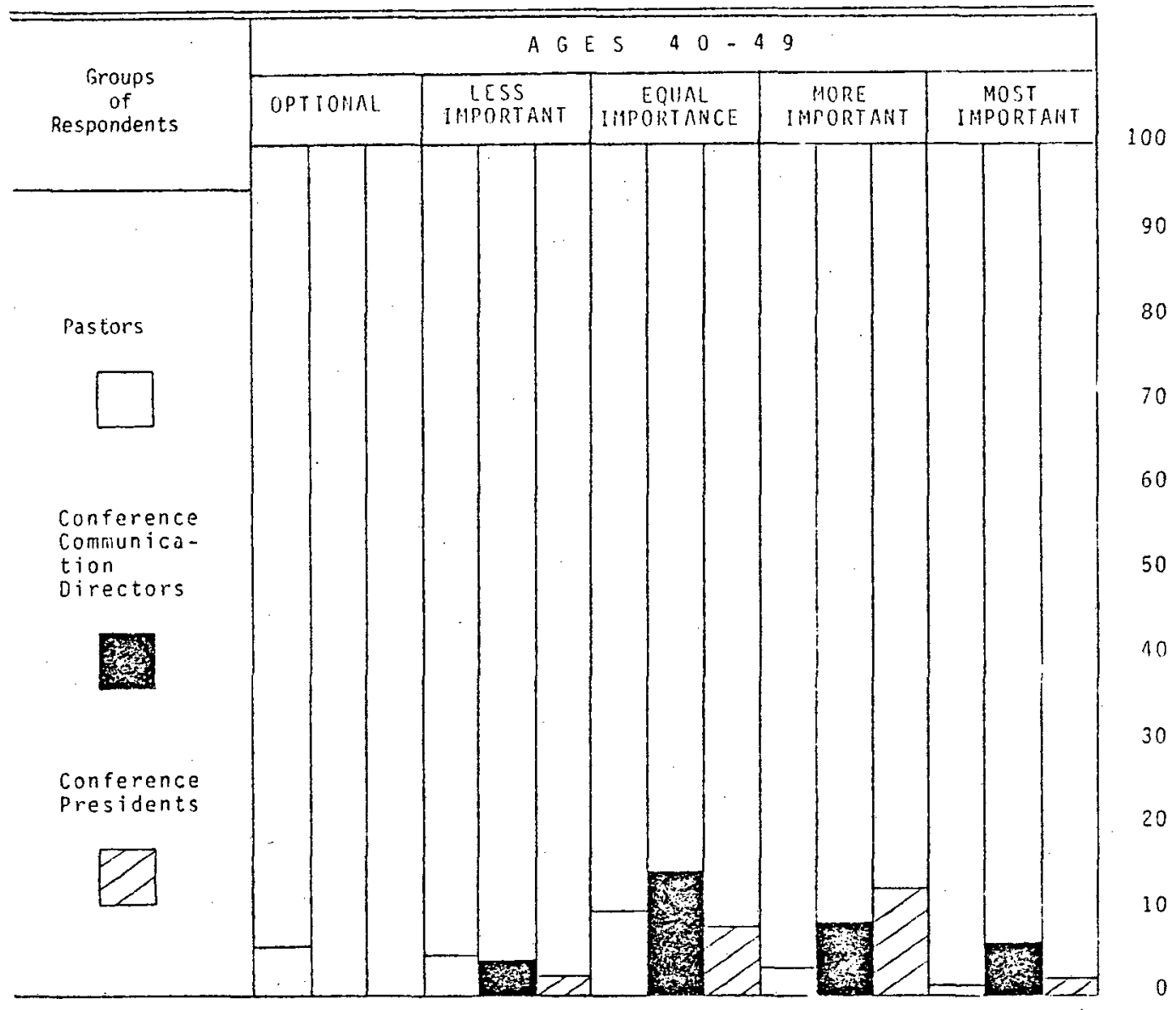

Fig. 19. Respondents' perceptions as to the relative importance of the work of the Conference Communication Director. 
Pastors 40 to 49 (figure 19) generally follow the same pattern as seen in figure 16 except that they are a little higher in the "optional" category (5.42 percent, table 28, column 3, and figure 19) than they are in the "less important" category (4.74 percent, table 28, column 3, and figure 19). Even though the difference is less than 1 percent, this could indicate a slightly more negative feeling by the 40 to 49 age group as to the effectiveness of this department from their view on the local conference level.

There was onty one communication director in the 20 to 29 age bracket. His (her) response was given for the "more important" category (2.04 percent, table 29, column 1, and figure 17). Since this response reflects the choice of only one individual, its importance to this section of the survey probably is negligible.

For communication directors, ages 50 to 59 , figure 20 shows a gradual rise into a peak and then a tapering off as with the majority of the respondents (figure 16). However, the lowest response begins with the "less important" category, continues to rise through "equal importance" to a peak in the "more important" category, and then drops down again to the "most important" end of the scale.

With the exception that their lowest response is given to the "optiona?" category and they register no response on the positive end of the scale (most important category), conference presidents, ages 50 to 59 (figure 20), show the same pattern of response as do communication directors for this age group. Both communication directors (10.20 percent, table 29, column 4, and 
TABLE 28

PASTORS' RESPONSE TO THE RELATIVE IMPORTANCE OF THE WORK OF THE CONFERENCE COMMUNICATION DIRECTOR

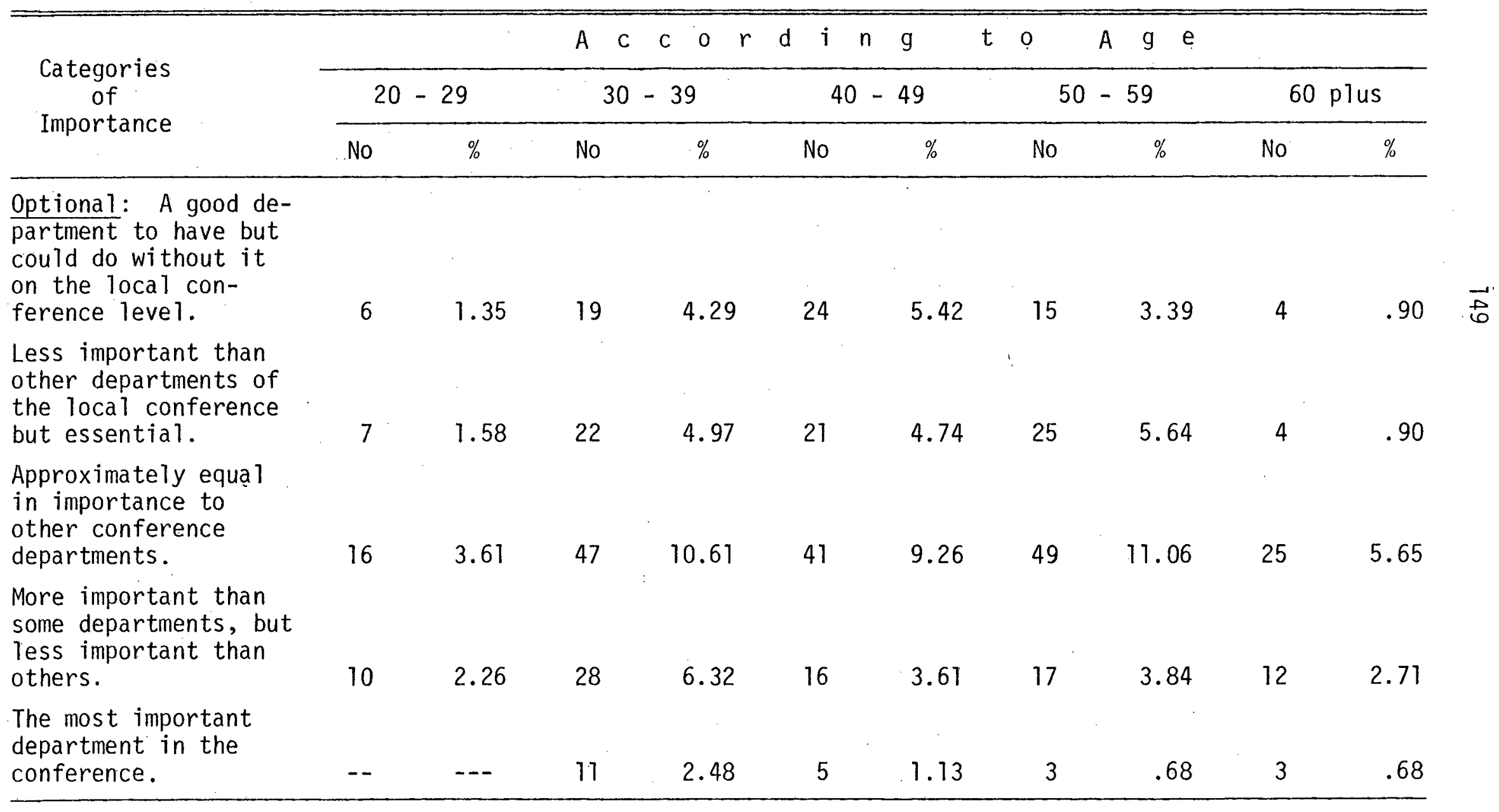




\section{TABLE 29}

CONFERENCE COMMUNICATION DIRECTORS' RESPONSE TO THE RELATIVE IMPORTANCE OF THE WORK OF THE CONFERENCE COMMUNICATION DIRECTOR

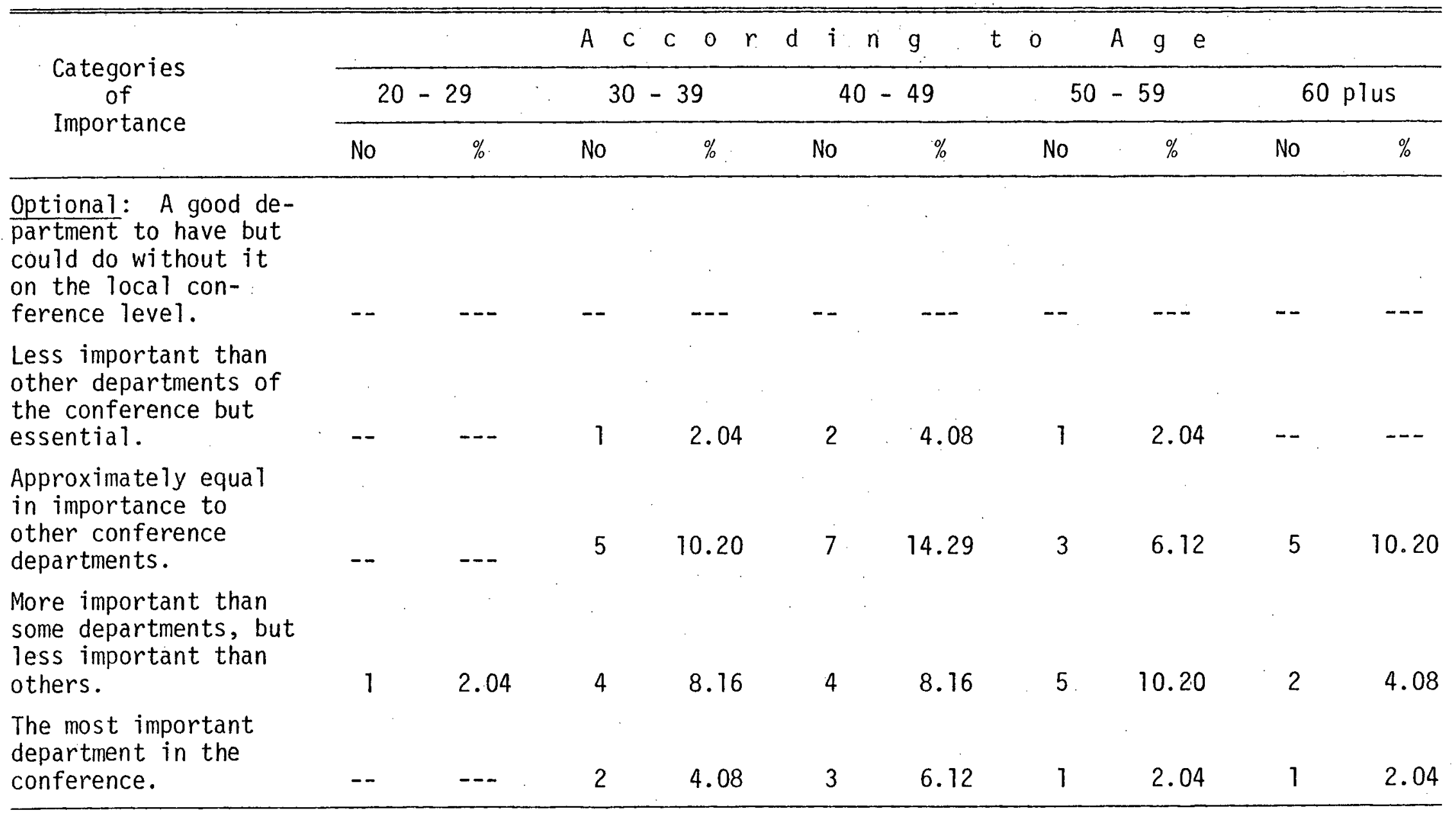




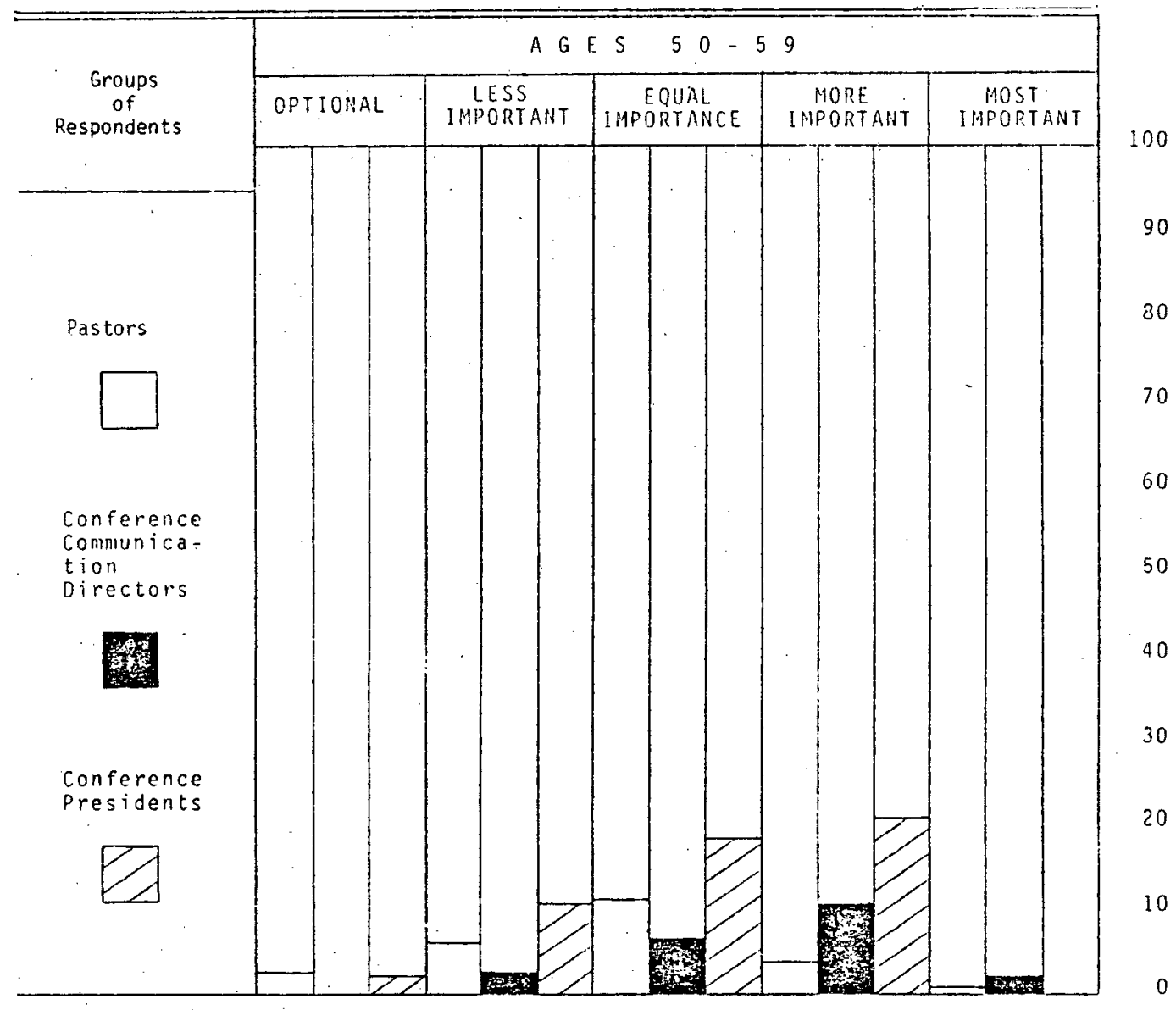

Fig. 20. Respondents' perceptions as to the relative importance of the work of the Conference Communication Director 
figure 20), and conference presidents, ages 50 to 59 (20.51 percent, table 30, column 4, and figure 20) give their highest responses to the conference communication department being "more important than some departments, but less important than others (figure 20).

The responses indicated by these two groups (communication directors and conference presidents), ages 50 to 59 , seem to show a more positive recognition by this age group than do any of the other respondents to the effectiveness of the communication department on the conference level.

Communication directors in the 60 plus age bracket gave no responses to the "optional" or "less important" categories. Their emphasis was on "the communication department being approximately equal in importance to other conference departments" (10.20 percent, table 29, column 5, and figure 21). From this high point there is a gradual tapering off to a low in the "most important" category. In this regard the 60 plus age group of communication directors are very much in line with the response consensus of the other groups of respondents for this section. That is, they also see the communication department as being "approximately equal in importance to other conference departments."

Probably due to the age limitation, no responses are given by conference presidents, ages 20 to 29 , for this section of the survey.

There were only three conference presidents, ages 30 to 39 (2.56 percent, table 30 , column 2, and figure 18) who responded to this section of the survey. They each checked a different category; one saw the communication department as being "less important" than 
TABLE 30

CONFERENCE PRESIDENTS' RESPONSE TO THE RELATIVE IMPORTANCE OF THE WORK OF THE CONFERENCE COMMUNICATION DIRECTOR

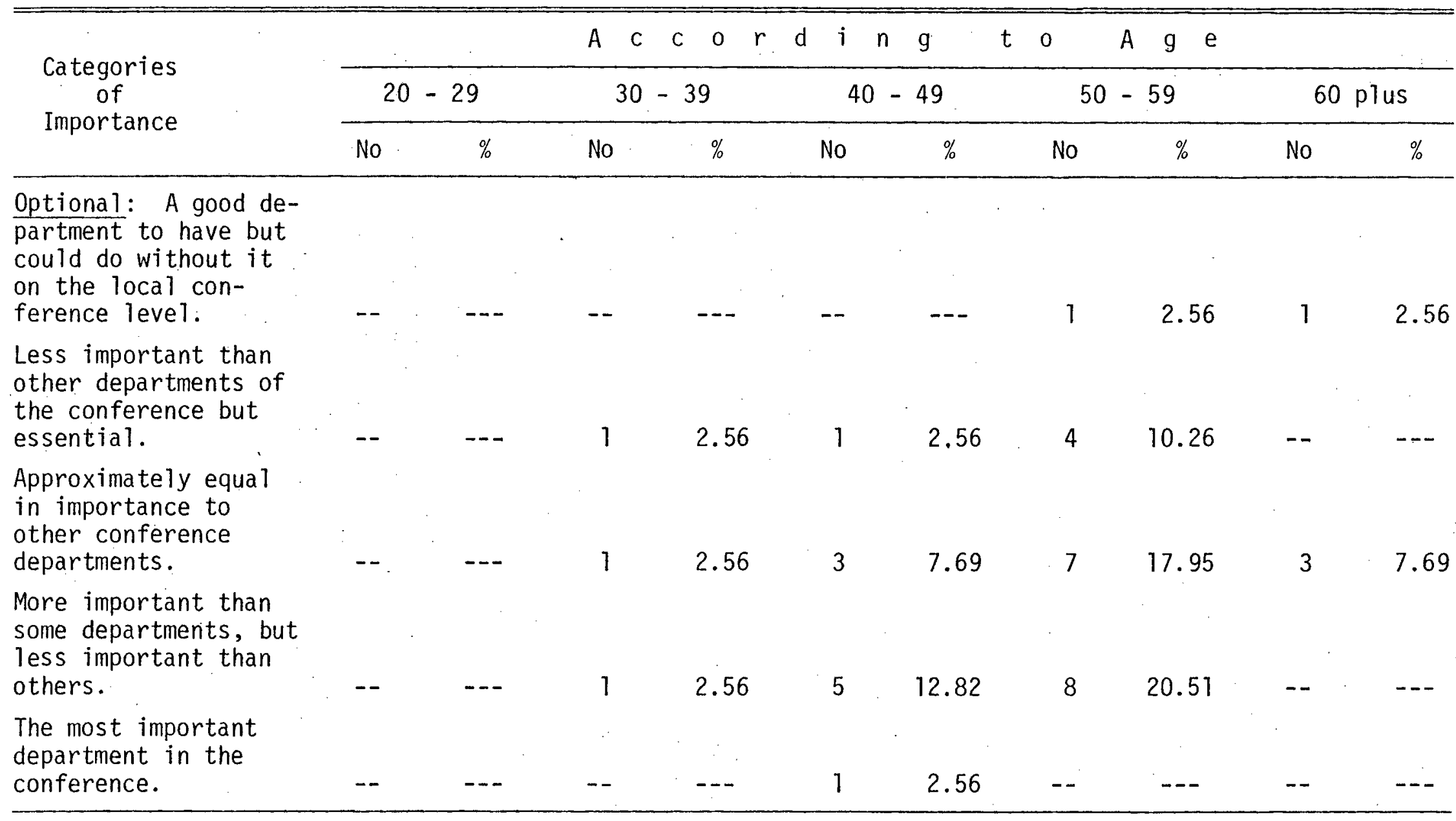




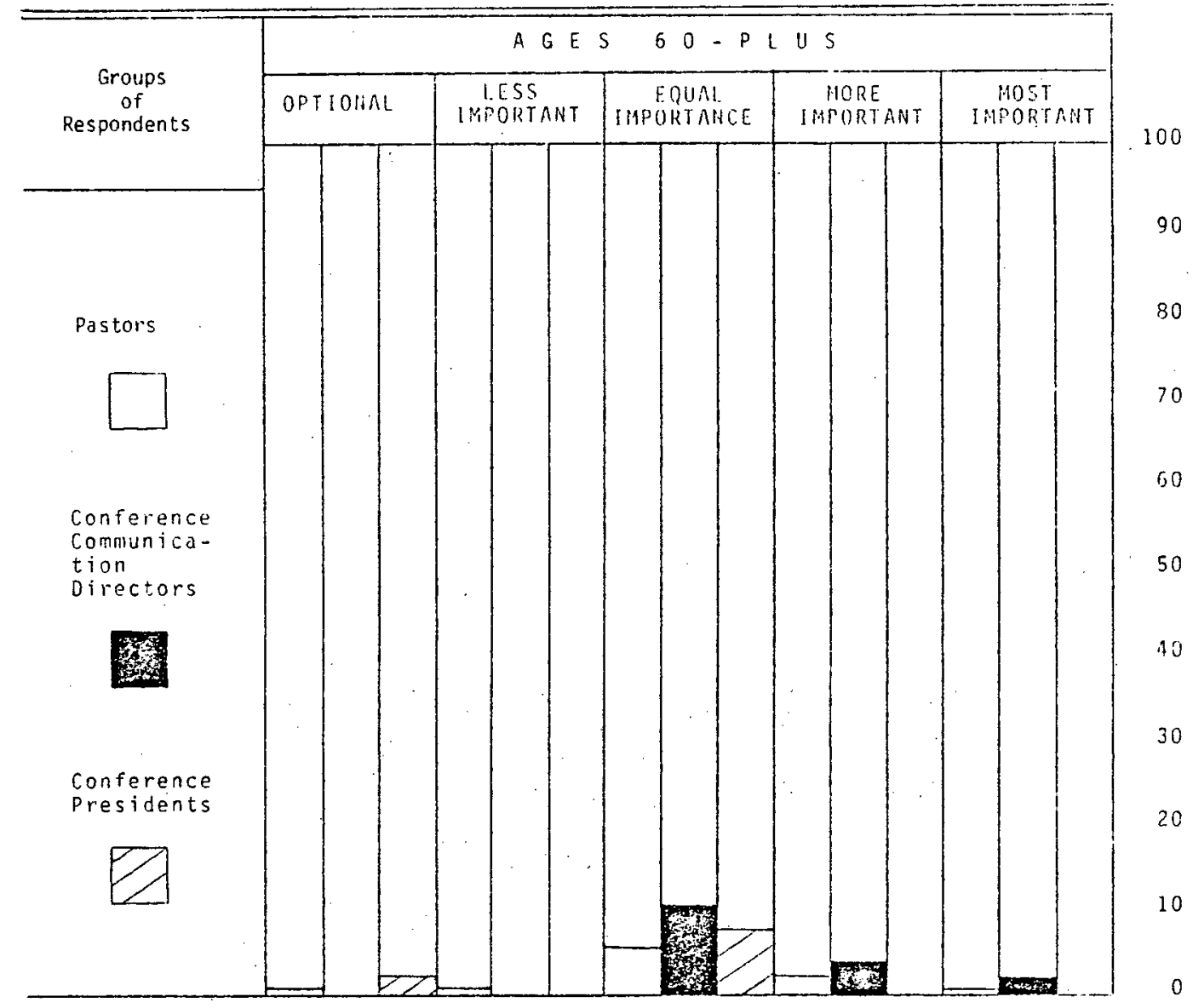

Fig. 21. Respondents' perceptions as to the relative importance of the work of the Conference Communication Director. 
other conference departments, the other saw it of "equal importance" to the other departments, and the third suggested that it was "more important than some departments but less important than others." No special meaning can be seen here by the researcher except to note the avoidance of extreme views by this age group (30 to 39 ) towards either end of the survey scale.

Only two categories, "optional" and "equal' importance," were given responses by conference presidents, ages 60 plus (figure 21). of the two, the "equal importance" category received the higher response ( 7.69 percent, table 30 , column 5 , and figure 21). This seems to indicate a view very much in harmony with the majority of the respondents, where the communication department is seen as "approximately equal in importance to other conference departments."

\section{Educational Background and Training of Respondents}

According to the survey, a majority of the respondents (pastors, communication directors, and conference presidents) majored in theology or religion in college (tables 31 to 34 ). Of the conference presidents, 82.05 percent (table 31, column 12, and table 34) give this area as their major field of study, as do pastors (80.81 percent, table 31 , column 12, and table 32), and communication directors (79.59 percent, table 31 , column 12, and table 33). It should be noted here that all three groups are within three percentage points of each other.

The major field of study given second place by the three groups of respondents is history for communication directors (12.24 percent, table 37, column 5, and table 33), history for 


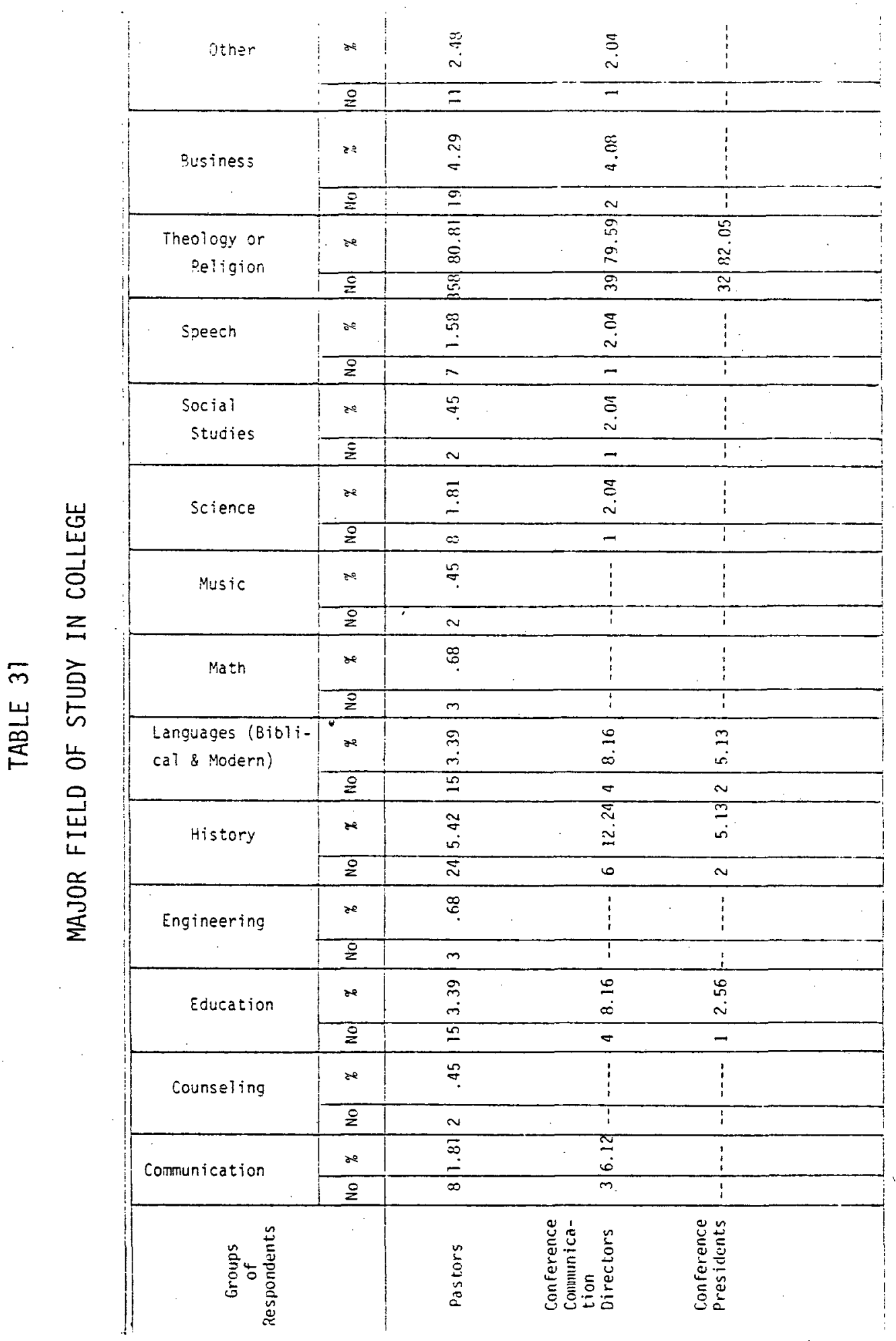


TABLE 32

MAJOR FIELD OF STUDY IN COLLEGE

\begin{tabular}{lrr}
\hline \hline \multirow{2}{*}{ Study Areas } & \multicolumn{2}{c}{ Pastors } \\
\cline { 2 - 3 } & No. & $\%$ \\
\hline 1. Theology or religion & 358 & 80.81 \\
2. History & 24 & 5.42 \\
3. Business & 19 & 4.29 \\
4. Education & 15 & 3.39 \\
5. Languages (biblical and modern) & 15 & 3.39 \\
6. Science & 8 & 1.81 \\
7. Communication & 8 & 1.81 \\
8. Speech & 7 & 1.58 \\
9. Engineering & 3 & .68 \\
10. Math & 3 & .68 \\
11. Counseling & 2 & .45 \\
12. Music & 2 & .45 \\
13. Social studies & 2 & .45 \\
\hline
\end{tabular}


TABLE 33

MAJOR FIELD OF STUDY IN COLLEGE

\begin{tabular}{llc}
\hline \hline Study Areas & \multicolumn{2}{c}{$\begin{array}{c}\text { Conference } \\
\text { Communication } \\
\text { Directors }\end{array}$} \\
\cline { 2 - 3 } & No. & $\%$ \\
\hline 1. Theology or religion & 39 & 79.59 \\
2. History & 6 & 12.24 \\
3. Education & 4 & 8.16 \\
4. Languages (biblical and modern) & 4 & 8.16 \\
5. Communication & 3 & 6.12 \\
6. Business & 2 & 4.08 \\
7. Science & 1 & 2.04 \\
8. Social Studies & 1 & 2.04 \\
9. Speech & 1 & 2.04 \\
10. Counseling & -- & --- \\
11. Engineering & -- & $-\ldots$ \\
12. Math & -- & $-\ldots$ \\
13. Music & -- &.-- \\
\hline
\end{tabular}


pastors (5.24 percent, table 31, column 5, and table 32), and history as well as languages for conference presidents (5.13 percent, table 31 , columns 5 and 6 , and table 34). However, as can be seen, all of these secondary college majors are far below the highest response percentages given to theology or religion. The difference varies from 67.35 to 76.92 percent.

Studies in business $(4.29$ percent, table 31 , column 13 , and table 32) was third, and education (3.39 percent, table 31, column 3, and table 32) fourth for pastors, with education (8.16 percent, table 31 , column 3 , and table 33) and languages (8.16 percent, table 31, column 6, and table 33) placed as third by communication directors, and communication (6.12 percent, table 31 , column 1, and table 33) in fourth place. Conference presidents give third place to a major in education $(2.56$ percent, table 31 , column 3, and table 34), but no response to a fourth major (table 34).

It is interesting to note the similar educational backgrounds for the three groups of respondents. Without question the main area of study, far in advance of any of the others, is theology or religion. Although the order differs, next to theology or religion all three categories of respondents marked history, education, and languages as major areas of study in college.

According to the responses given, none of the conference presidents (table 31, column 1 and table 34), eight of the pastors (1.81 percent, table 31 , column 1 , and table 32), and only three of the conference communication directors (6.12 percent, table 31 , 
TABLE 34

MAJOR FIEL.D OF STUDY IN COLLEGE

\begin{tabular}{llrr}
\hline & & \multicolumn{2}{c}{$\begin{array}{c}\text { Conference } \\
\text { Presidents }\end{array}$} \\
\cline { 2 - 4 } & No. & $\%$ \\
\hline 1. Theology or religion & 32 & 82.05 \\
2. Languages (biblical and modern) & 2 & 5.13 \\
3. History & 2 & 5.13 \\
4. Education & 1 & 2.56 \\
5. Communication & -- &.-- \\
6. Science & -- & -- \\
7. Social studies & -- & -- \\
8. Speech & -- & -- \\
9. Business & -- & -- \\
10. Counseling & -- & -- \\
11. Engineering & -- & -- \\
12. Math & -- & -- \\
13. Music & -- & - \\
\hline
\end{tabular}


column 1, and table 33) majored in communication in college. Most of the communication training received by the three groups of respondents was post-graduate job-related training (table 37 ).

Since the researcher does not feel that additional remarks by the respondents pertaining to this section of the survey and recorded under the category "other" (table 31, column 14) substantially alter the trends previously mentioned, they have been listed in appendix L. (This also applies to the column marked "other" found in tables 35 to 37 , 7 isted in appendix $M$ and N.)

Tables 35 and 36 show the areas of emphasis of those respondents who either majored or minored in communication in college. As can be observed, all of the respondents have relatively low response percentages to the communication course options listed. The very highest is 10.20 percent which is for communication directors in the field of speech (table 36).

All of the respondents for this section of the survey show their highest response percentages for "post-graduate job-related training in communication" (table 37). In other words, most of their formal training in communication had been received after college. In comparing the three groups with each other, pastors are found to have the lowest average response rating for this section, with the exception of speech where they are highest (17.38 percent, table 37), whereas the communication directors and conference presidents in most categories have the highest responses, ranging from a low of 5.13 percent in speech (conference presidents) to a high of 42.86 percent in $P R$ (communication directors). In journalism, PR, and radio-TV training, 
TABLE 35

COLLEGE MAJOR IN COMMUNICATION:

AREAS OF EMPHASIS

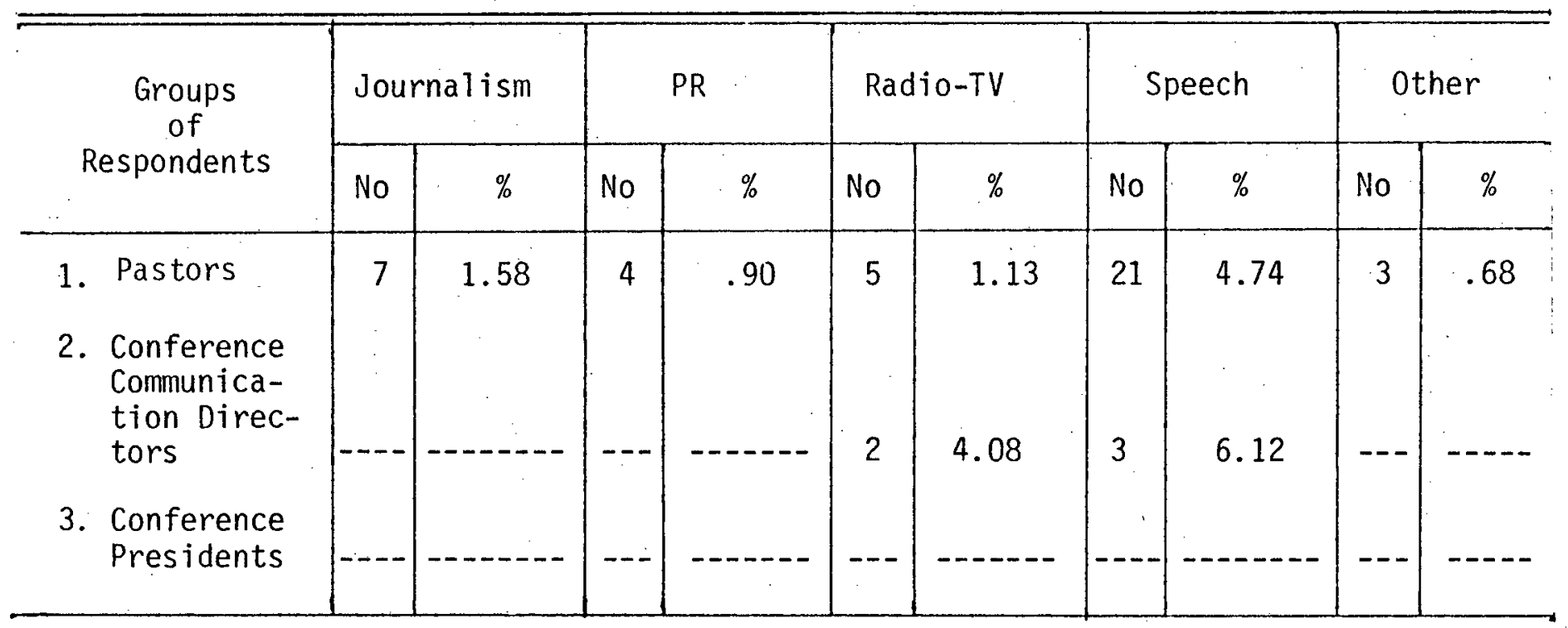


TABLE 36

COLLEGE MINOR IN COMMUNICATION: AREAS OF EMPHASIS

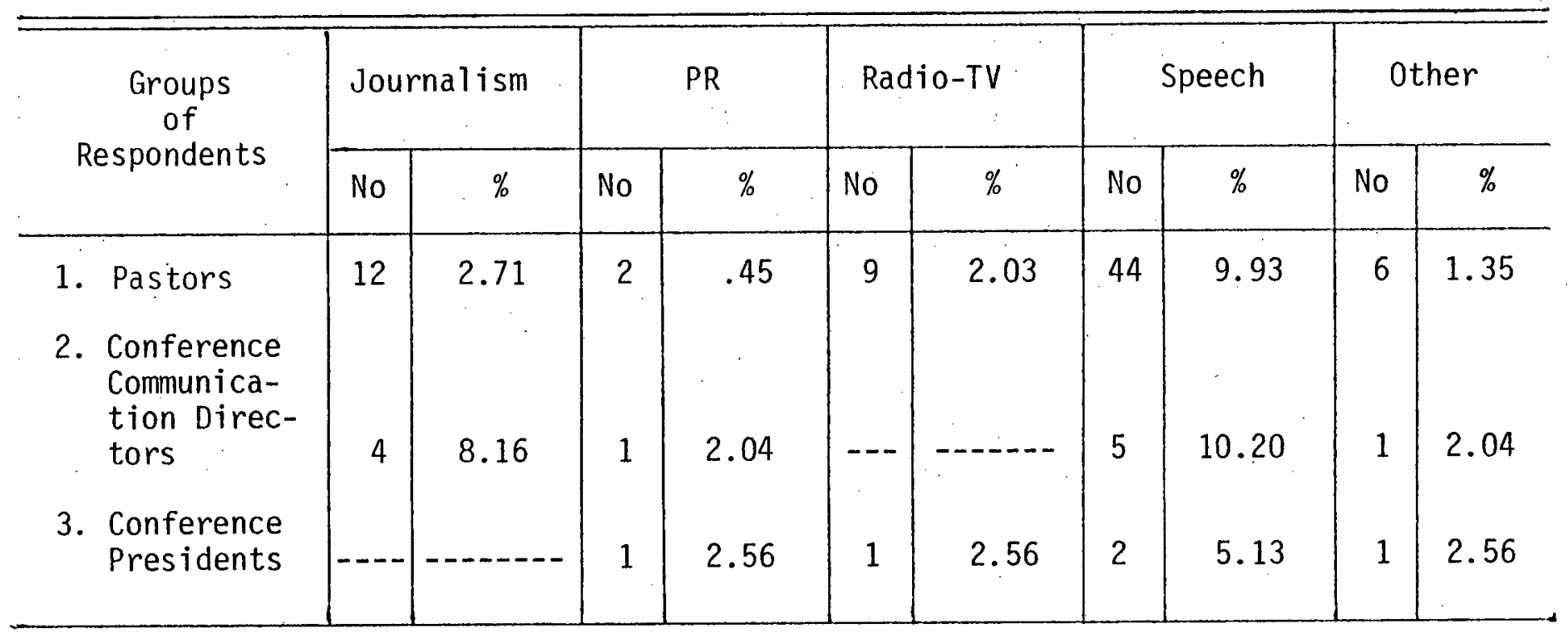




\section{TABLE 37}

POST-GRADUATE JOB-RELATED TRAINING IN COMMUNICATION

\begin{tabular}{|c|c|c|c|c|c|c|c|c|c|c|}
\hline \hline $\begin{array}{c}\text { Groups } \\
\text { of } \\
\text { Respondents }\end{array}$ & \multicolumn{2}{|c|}{ Journalism } & \multicolumn{2}{|c|}{ PR } & \multicolumn{2}{|c|}{ Radio-TV } & \multicolumn{2}{|c|}{ Speech } & \multicolumn{2}{c|}{ 0ther } \\
\cline { 2 - 10 } & No & $\%$ & No & $\%$ & No & $\%$ & No & $\%$ & No & $\%$ \\
\hline $\begin{array}{c}\text { 1. Pastors } \\
\text { 2. Conference } \\
\text { Communica- } \\
\text { tion Direc- } \\
\text { tors } \\
\begin{array}{c}\text { Conference } \\
\text { Presidents }\end{array}\end{array}$ & 11 & 11.51 & 87 & 19.64 & 95 & 21.44 & 77 & 17.38 & 23 & 5.19 \\
\hline
\end{tabular}


communication directors and conference presidents are within a 4 to 7 percent range of each other. This could indicate the ability of either or both groups of respondents to function with equal skill (or lack of it) within these specific areas of communication or to give guidance in these areas.

It would seem by the responses given that many of the respondents (pastors, communication directors, and conference presidents) have had at least some post-graduate training in certain areas within the communication field. However, as to the extent of this training, the researcher can only conjecture.

The responses of the respondents concerning their own experience in those fields related to public relations or communication (tables 38 to 44 ) appear to be highly subjective due to each group's understanding of the scope and purpose of the public relations or communication field. This subjectiveness seems to be a possible reason behind the broad spectrum of "experience" in the field of communication as indicated in the survey by the following respondents.

According to the pastors, the area of communication where they felt they had gained the most experience was in pastoral work (18.60 percent, table 38, column 3, and table 42). Second was their experience in radio and TV work (10.84 percent, table 38, column 6, and table 42), with those pastors who had had experience as conference communication directors (2.93 percent, table 38 , column 2, and table 42) being third. The remainder of the table shows rather low response percentages (and in most cases no responses are made in those areas viewed by the respondents as fields 


\section{TABLE 38}

EXPERIENCE IN THOSE FIELDS RELATED TO PUBLIC RELATIONS OR COMMUNICATION I

\begin{tabular}{|c|c|c|c|c|c|c|c|c|c|c|c|c|c|c|c|c|c|c|c|c|}
\hline \multirow[t]{2}{*}{$\begin{array}{l}\text { Groups of } \\
\text { Respondents }\end{array}$} & \multicolumn{2}{|c|}{ 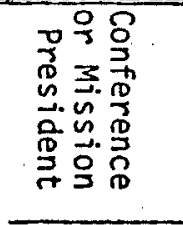 } & \multicolumn{2}{|c|}{ 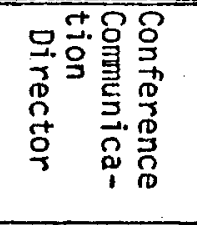 } & \multicolumn{2}{|c|}{ 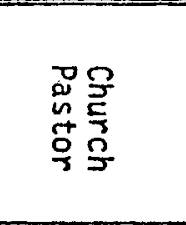 } & \multicolumn{2}{|c|}{ 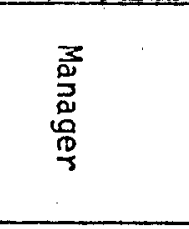 } & \multicolumn{2}{|c|}{$\frac{m}{\stackrel{m}{\alpha}}$} & \multicolumn{3}{|c|}{ 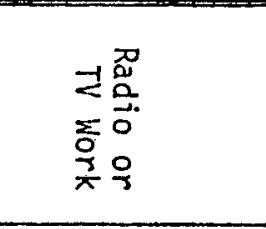 } & \multicolumn{2}{|l|}{ 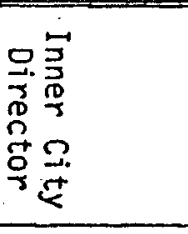 } & \multirow{2}{*}{ 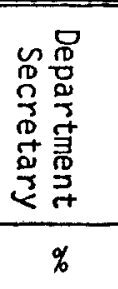 } & \multicolumn{2}{|c|}{ 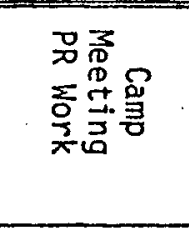 } & \multicolumn{2}{|c|}{ 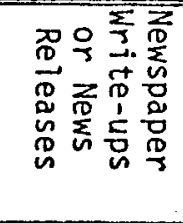 } \\
\hline & No & $\%$ & No & $\%$ & No & $\%$ & No & $\%$ & No & $\%$ & No & $\%$ & No & $\%$ & No & & No & $\%$ & No & $\%$ \\
\hline Pastors & 4 & .90 & $\cdot 13$ & 2.93 & 80 & 18.60 & 2 & .45 & 3 & .68 & 48 & 10.84 & 1 & .23 & 2 & .45 & 3 & .68 & 3 & .68 \\
\hline $\begin{array}{l}\text { Conference } \\
\text { Communica- } \\
\text { tion }\end{array}$ & & & - & & & & & & & & & & & & & & & & & \\
\hline Directors & 2 & 4.08 & 25 & 53.06 & 1 & 2.04 & -- & $-\cdots$ & 1 & 2.04 & 2 & 4.08 & -- & --- & $-r$ & --- & 1 & 2.04 & -- & -- \\
\hline $\begin{array}{l}\text { Conference } \\
\text { Presidents }\end{array}$ & 3 & 7.69 & 11 & 28.21 & 1 & 2.56 & -- & $-\infty$ & -- & -- & 1 & 2.56 & -- & --- & 2 & 5.13 & 1 & 2.56 & $\therefore$ & $\cdots$ \\
\hline
\end{tabular}


related to the work of communication).

With regards to their experience in communication, conference communication directors, as could be expected, give their highest response to the work of the "conference communication director" (53.06 percent, table 38, column 2, and table 4.3), and their second highest as experience gained in "administration" (6.12 percent, table 39, column 6, and table 43). However, it should be noted that there is almost 47 percent difference between their first and second responses which may indicate a much greater degree of importance attached to the experience gained as "communication directors" over that of "administration." The third area indicated was the experience they had gained as "conference or mission presidents" (4.08 percent, table 38, column 1, and table 43) and in "radio or TV work" (4.08 percent, table 38, column 6, and table 43).

A relatively large number of the conference presidents indicated they had had previous experience as "conference communication directors" (28.21 percent, table 38, column 2, and table 44). They also said they had gained experience in communication through their work as "conference or mission presidents" (7.69 percent, table 38, column 1, and table 44) and through a variety of departmental posts ( 5.13 percent, table 38 , column 8 , and table 44). Regardless of the degree of their experience, this could at least indicate some of the presidents' willingness to understand and appreciate the work of the communication director.

A] though in different order, all three groups of respondents indicate that their past or present experience as communication 
TABLE 39

EXPERIENCE IN THOSE FIELDS RELATED TO PUBLIC RELATIONS OR COMMUNICATION II

\begin{tabular}{|c|c|c|c|c|c|c|c|c|c|c|c|c|c|c|c|c|c|c|c|c|}
\hline \multirow[t]{2}{*}{$\begin{array}{l}\text { Groups of } \\
\text { Respondents }\end{array}$} & \multicolumn{2}{|c|}{$\begin{array}{l}0 \\
0 \\
0\end{array}$} & \multicolumn{2}{|c|}{ 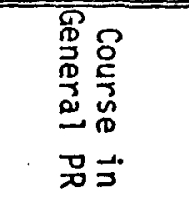 } & \multicolumn{2}{|c|}{ 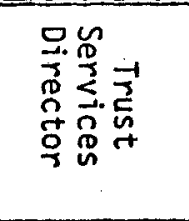 } & \multicolumn{2}{|c|}{ 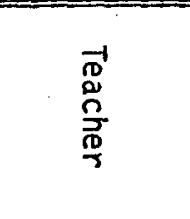 } & \multicolumn{2}{|c|}{ 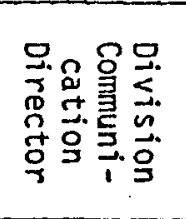 } & \multicolumn{2}{|c|}{ 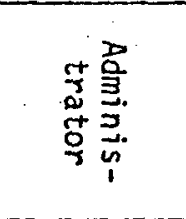 } & \multicolumn{2}{|c|}{ 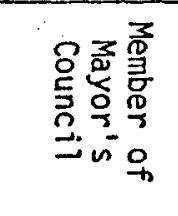 } & \multicolumn{2}{|c|}{ 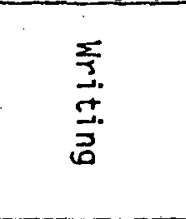 } & \multicolumn{2}{|c|}{$\begin{array}{l}8 \\
0 \\
8 \\
3 \\
+\frac{0}{0} \\
\frac{1}{3}\end{array}$} & \multicolumn{2}{|c|}{ 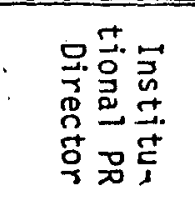 } \\
\hline & No & $\%$ & No & $\%$ & No & $\%$ & No & $\%$ & No & $\%$ & No & $\%$ & No & $\%$ & No & $\%$ & No & $\%$ & No & $\%$ \\
\hline Pastors & 9 & 2.03 & 2 & .45 & 1 & .23 & 6 & 1.35 & 2 & .45 & 4 & .90 & 1 & .23 & 1 & .23 & 1 & .23 & 3 & .68 \\
\hline $\begin{array}{l}\text { Conference } \\
\text { Communica- } \\
\text { tion }\end{array}$ & & & & & & & & & & & & 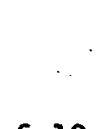 & & & & & & & & \\
\hline Directors & -- & $-\infty$ & -- & $-\infty$ & -- & $-\infty$ & $\cdots$ & $-\infty$ & -- & $\cdots$ & 3 & 6.12 & -- & $\cdots$ & 1 & 2.04 & -- & $\cdots$ & -- & --- \\
\hline $\begin{array}{l}\text { Conference } \\
\text { Presidents }\end{array}$ & -- & -- & -- & $-\cdots$ & 1 & 2.56 & -- & $-\cdots$ & -- & -- & - & -- & -- & --- & -- & --- & -- & $\cdots$ & $\cdots$ & $\cdots$ \\
\hline
\end{tabular}


TABLE 40

EXPERIENCE IN THOSE FIELDS RELATED TO PUBLIC RELATIONS OR COMMUNICATION III

\begin{tabular}{|c|c|c|c|c|c|c|c|c|c|c|c|c|c|c|c|c|c|c|c|c|}
\hline \multirow[t]{2}{*}{$\begin{array}{l}\text { Groups of } \\
\text { Respondents }\end{array}$} & \multicolumn{2}{|c|}{ 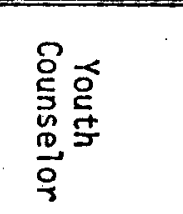 } & \multicolumn{2}{|c|}{ 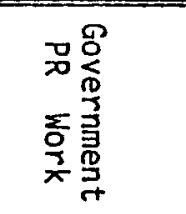 } & \multicolumn{2}{|c|}{ 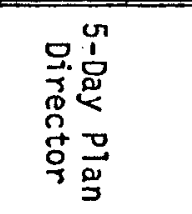 } & \multicolumn{2}{|c|}{ 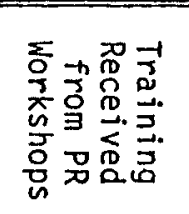 } & \multicolumn{2}{|c|}{ 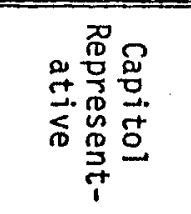 } & \multicolumn{2}{|c|}{ 言总 } & \multicolumn{2}{|c|}{ 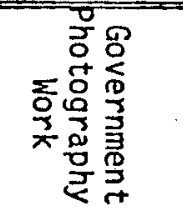 } & \multicolumn{2}{|c|}{ 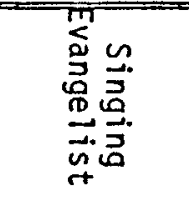 } & \multicolumn{2}{|c|}{ 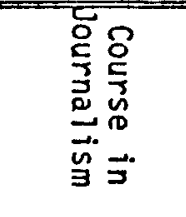 } & \multicolumn{2}{|c|}{ 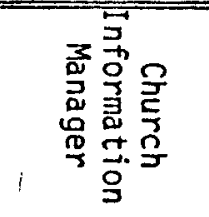 } \\
\hline & No & $\%$ & No & $\%$ & No & $\%$ & No & $\%$ & No & $\%$ & No & $\%$ & No & $\%$ & No & $\%$ & No & $\%$ & No & $\%$ \\
\hline Pastors & 1 & .23 & 1 & .23 & 2 & .45 & 1 & .23 & 1 & .23 & 1 & .23 & 1 & .23 & 1. & .23 & 2 & .45 & 1. & .23 \\
\hline $\begin{array}{l}\text { Conference } \\
\text { Communica- } \\
\text { tion }\end{array}$ & & & & & & & & & & & & & & & & & & & 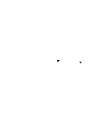 & \\
\hline Directors & - & $\cdots$ & $-\infty$ & -- & - & $-\infty$ & -- & -- & -- & -- & -- & --- & -- & $\cdots$ & -- & -- & -- & -- & -- & -- \\
\hline $\begin{array}{l}\text { Conference } \\
\text { Presidents }\end{array}$ & -- & $=-$ & $\therefore$ & -- & -- & $-\infty$ & -- & $\cdots$ & -- & -- & -- & -- & -- & -- & - & -- & -- & $--\infty$ & $\because$ & -- \\
\hline
\end{tabular}


TABLE 41

EXPERIENCE IN THOSE FIELDS RELATED TO PUBLIC RELATIONS OR COMMUNICATION IV

\begin{tabular}{|c|c|c|c|c|c|c|c|c|c|c|c|c|c|c|c|c|c|c|}
\hline \multirow[t]{2}{*}{$\begin{array}{l}\text { Groups of } \\
\text { Respondents }\end{array}$} & \multicolumn{2}{|c|}{ 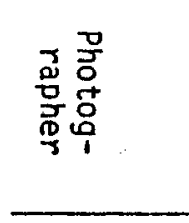 } & \multicolumn{2}{|c|}{ 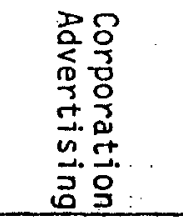 } & \multicolumn{2}{|c|}{ 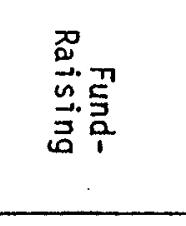 } & \multicolumn{2}{|c|}{ 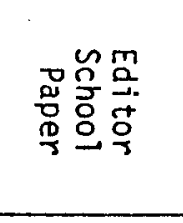 } & \multicolumn{2}{|c|}{ 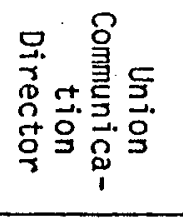 } & \multicolumn{2}{|r|}{ 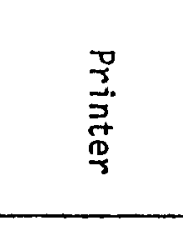 } & \multicolumn{2}{|r|}{ 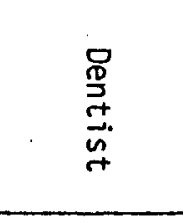 } & \multicolumn{2}{|c|}{ 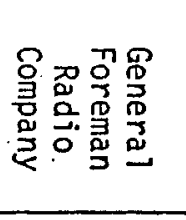 } & \multicolumn{2}{|c|}{ 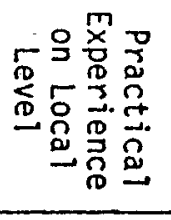 } \\
\hline & No & $\%$ & No & $\%$ & No & $\%$ & No & $\%$ & No & $\%$ & No & $\%$ & No & $\%$ & No & $\%$ & No & $\%$ \\
\hline Pastors & 1 & .23 & 1 & .23 & 1 & .23 & 1 & .23 & 1 & .23 & 1 & .23 & 1 & .23 & 1 & .23 & 1 & .23 \\
\hline $\begin{array}{l}\text { Conference } \\
\text { Communica- } \\
\text { tion }\end{array}$ & & & & & & & & & & & & & & & & & & \\
\hline Directors & -- & --- & -- & --- & -- & -- & -- & -- & -- & -- & -- & $-\infty$ & -- & -- & -- & $-\infty$ & -- & --- \\
\hline $\begin{array}{l}\text { Conference } \\
\text { Presidents }\end{array}$ & -- & -- & -- & -- & -- & $-\cdots$ & -- & --- & -- & --- & -- & -- & -- & --- & -- & -- & -- & -- \\
\hline
\end{tabular}


TABLE 42

EXPERIENCE IN THOSE FIELDS RELATED TO PUBLIC RELATIONS OR COMMUNICATION

Areas of Experience

Pastors

No. $\%$

1. Church pastor

80

18.06

2. Radio or TV work

48

10.84

3. Conference communication director

13

2.93

4. Local church PR work

1.03

5. Teacher

1.35

6. Administrator

.90

7. Conference or mission president

.90

8. Newspaper write-ups or news releases

.68

9. Editor

.68

10. Institutional $P R$ director

.68

11. Camp meeting PR work

.68

12. Department secretary

.45

13. Manager

.45

14. Division communication director

.45

15. Course in general PR

.45

16. 5-Day Plan director

.45

17. Course in journalism

.45

18. Inner city director

.23

19. Trust services director

20. Member of mayor's counci]

21. Writing

22. Colporteur

23. Youth counselor

24. Government PR work

25. Training received from PR workshops

26. Capitol representative

27. Publishing work

28. Government photography work 
TABLE 42--Continued

\begin{tabular}{lll}
\hline & \multicolumn{2}{c}{ Pastors } \\
\cline { 2 - 3 } Areas of Experience & No & $\%$ \\
\hline 29. Singing evangelist & 1 & .23 \\
30. Church information manager & 1 & .23 \\
31. Photographer & 1 & .23 \\
32. Corporation advertising & 1 & .23 \\
33. Fund-raising & 1 & .23 \\
34. Editor school paper & 1 & .23 \\
35. Union communication director & 1 & .23 \\
36. Printer & 1 & .23 \\
37. Dentist & 1 & .23 \\
38. General foreman radio company & 1 & .23 \\
39. Practical & 1 & .23 \\
\hline
\end{tabular}




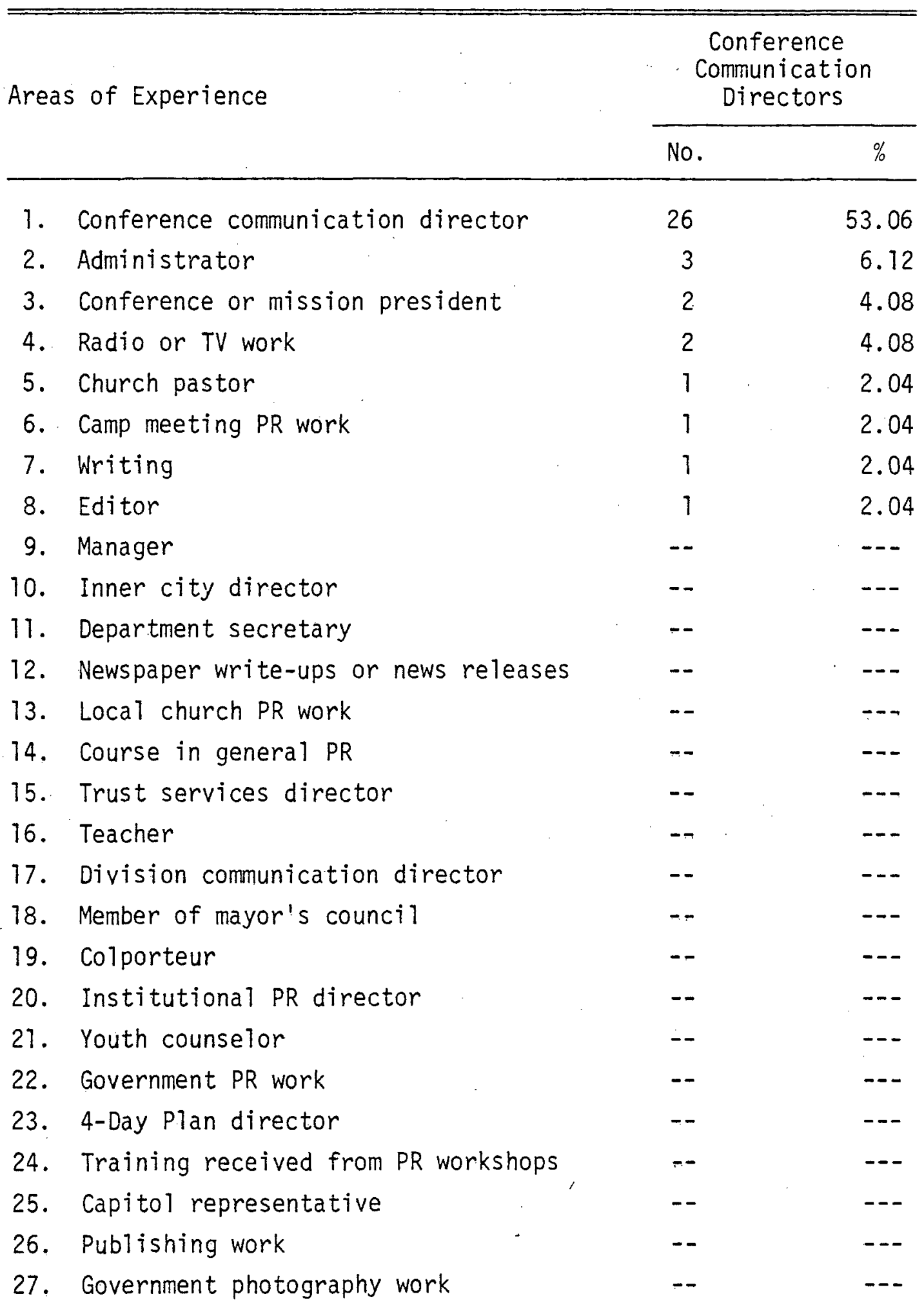


TABLE 43--Continued

\begin{tabular}{|c|c|c|c|}
\hline \multirow{2}{*}{\multicolumn{2}{|c|}{ Areas of Experience }} & \multicolumn{2}{|c|}{$\begin{array}{l}\text { Conference } \\
\text { Communication } \\
\text { Directors }\end{array}$} \\
\hline & & No. & $\%$ \\
\hline 28. & Singing evangelist & -- & -- \\
\hline 29. & Course in journalism & -- & --- \\
\hline 30. & Church information manager & -- & --- \\
\hline 31.1 & Photographer & - & -- \\
\hline 32. & Corporation advertising & -- & -- \\
\hline 33. & Fund-raising & -- & -- \\
\hline 34. & Editor school paper. & -- & --- \\
\hline 35. & Union communication director & -- & --- \\
\hline 36.1 & Printer & -- & $-\cdots$ \\
\hline 37. & Dentist & -- & --- \\
\hline 38. & General foreman radio company & -- & --- \\
\hline 39.1 & Practical experience on local level & -- & --- \\
\hline
\end{tabular}


TABLE 44

EXPERIENCE IN THOSE FIELDS RELATED TO PUBLIC RELATIONS OR COMMUNICATION

\begin{tabular}{|c|c|c|c|}
\hline \multirow[t]{2}{*}{ Areas } & \multirow[t]{2}{*}{ of Experience } & \multicolumn{2}{|c|}{$\begin{array}{l}\text { Conference } \\
\text { Presidents }\end{array}$} \\
\hline & & No. & $\%$ \\
\hline 1. & Conference communication director & 11 & 28.21 \\
\hline 2. $c$ & Conference or mission president & 3 & 7.69 \\
\hline 3. [ & Department secretary & 2 & 5.13 \\
\hline 4. $\quad$ & Church pastor & 1 & 2.56 \\
\hline 5. F & Radio or TV work & 1 & 2.56 \\
\hline 6. & Camp meeting PR work & 1 & 2.56 \\
\hline 7.7 & Trust services director & 1 & 2.56 \\
\hline 8. 1 & Manager & -- & --- \\
\hline 9. & Editor & -- & --- \\
\hline 10. 1 & Inner city director & -- & $-\cdots$ \\
\hline 11.1 & Newspaper write-up or news release & -- & --- \\
\hline 12. 1 & Local church PR work & -- & --- \\
\hline 13. & Course in general PR & -- & --- \\
\hline 14. 7 & Teacher & -- & --- \\
\hline 15. & Division communication director & -- & --- \\
\hline 16. & Administrator & -- & --- \\
\hline 17.1 & Member of mayor's council & -- & --- \\
\hline 18. 1 & Writing & -- & --- \\
\hline 19. & Colporteur & - & --- \\
\hline 20. & Institutional PR director & -- & --- \\
\hline 21. & Youth counselor & -- & --- \\
\hline 22. & Government PR work & - & $-\cdots$ \\
\hline 23 & 5-Day Plan director & -- & $-\cdots$ \\
\hline 24. & Training received from PR workshops & -- & -- \\
\hline 25. & Capitol representative & - & $-\cdots$ \\
\hline 26. & Publishing work & - & -- \\
\hline 27 & Government photography work & -- & --- \\
\hline 28. & Singing evangelist & -- & -- \\
\hline
\end{tabular}


TABLE 44--Continued

\begin{tabular}{llc}
\hline \hline & \multicolumn{2}{c}{$\begin{array}{c}\text { Conference } \\
\text { Presidents }\end{array}$} \\
\cline { 2 - 3 } & No. & $\%$ \\
\hline 29. Course in journalism & -- & -- \\
30. Church information manager & -- & -- \\
31. Photographer & -- & --- \\
32. Corporation advertising & -- & -- \\
33. Fund-raising & -- & - \\
34. Editor school paper & -- & -- \\
35. Union communication director & -- & -- \\
36. Printer & -- & -- \\
37. Dentist & -- & -- \\
38. General foreman radio company & -- & - \\
39. Practical experience on local level & - & \\
\hline
\end{tabular}

directors is a factor in the practical knowledge they have gained in the communication field. Both pastors and communication directors also indicate that they have gained experience in their work with radio and television.

Degree of Acquaintance Pastors Have With the Conference Communication Director

This section of the survey explores the kind of relationship which exists between pastors and communication directors. As observed in table 45 , most of the pastors indicate that they are "well acquainted" with the communication director (63.66 percent). However, under the category "other" (table 45, also appendix 0) nine of the pastors qualified this statement by saying they were "well acquainted with the communication director 
but received little assistance from him." Still others suggested that they only received assistance from him when they asked for it. (This thought surfaced quite regularly throughout the survey.)

TABLE 45

DEGREE OF ACQUAINTANCE PASTORS HAVE WITH THE LOCAL CONFERENCE COMMUNICATION DIRECTOR

\begin{tabular}{lcc}
\hline \hline Relationship to Communication Director & No. & $\%$ \\
\hline 1. Don't know who he is. & 15 & 3.39 \\
2. Know who he is but have never met him. & 16 & 3.61 \\
3. Have met him, but have received little & & \\
if any assistance from him. & 95 & 21.44 \\
4. Am well acquainted with him. & 282 & 63.66 \\
5. Other & 46 & 10.38
\end{tabular}

The next highest response was for those who said they had "met him, but had received little if any assistance from him" (21.44 percent, table 45). Except for the degree of acquaintance, this response is the same as for those pastors previously mentioned who said they were "well acquainted with him, but had received little assistance from him."

There was a similar response between those who said they "know who he is, but had never met him ( 3.61 percent, table 45), and those who said they "didn't know who he is" (3.39 percent, table 45).

If the response percentages for the first three categories of table 45 ("don't know who he is," 3.39 percent; "know who he is, but have never met him," 3.61 percent; "have met him, but have received little if any assistance from him," 21.44 percent) are 
added to the response percentages of the nine pastors $(2.03$ percent of the 10.38 percent under the category "other") who said "they were we11 acquainted with the communication director but had received little assistance from him," the total is 30.47 percent. This response percentage, based on a minimum rather than a maximum acquaintance level (63.66 percent being the maximum level, table 45) between pastors and communication directors, may reflect a reserved attitude on the part of a relatively large number of pastors to the work and ministry of the conference communication director on the local lever.

As they are not seen by the researcher to alter the trends observed in this section of the survey, all of the responses recorded under the category "other" (table 45), except the responses of the nine pastors previously mentioned, are listed in appendix 0.

$$
\frac{\text { Areas Concentrated on the Most Frequently }}{\frac{\text { by Local Conference Communication }}{\text { Directors During a Typical }}}
$$

Table 46 shows the results of the responses made by the conference communication directors to those areas of communication they see themselves the most frequentiy involved in during a typical three month period.

At the head of the list is "writing" (73.47 percent, table 46), with "photo coverage of church-related events" (63.41 percent, table 46) second, "preparation of resource and promotional materials" (26.53 percent, table 46) third, and "editing" (14.29 percent, table 46) fourth. 
TABLE 46

AREAS OF COMMUNICATION CONCENTRATED ON THE MOST

FREQUENTLY BY CONFERENCE COMMUNICATION

DIRECTORS DURING A TYPICAL THREE

MONTH PERIOD

\begin{tabular}{lll}
\hline \multicolumn{1}{c}{ Areas of Concentration } & No. & $\%$ \\
\hline 1. Writing & 36 & 73.47 \\
2. Photo Coverage of Church- & 32 & 65.31 \\
$\quad \begin{array}{l}\text { Related Events } \\
\text { 3. Preparation of Resource and }\end{array}$ & 13 & 26.53 \\
Promotional Materials & 7 & 14.29 \\
4. Editing & 5 & 10.20 \\
5. Fund-raising Activities & 3 & 6.12 \\
6. Counseling & 2 & 4.08 \\
7. Radio \& TV Work & 2 & 4.08 \\
8. Involvement in Solving PR Problems & & 4.08 \\
9. Involvement in Local PR Training & 2 & 4.08 \\
10. Other & 2 & \\
\hline
\end{tabular}

It is interesting to note here that not all, but most of the activities communication directors are involved in during a typical three month period seem to be mostly office-oriented; whereas those that are more directly people-oriented are found on the lower end of the percentage scale, such as "counseling" (6.72 percent, table 46), "involvement in solving PR problems" (4.08 percent, table 46) and "involvement in local PR training programs" (4.08 percent, table 46). This type of orientation seems to be reflected in the pleas and complaints of two of the 
pastors surveyed who help to illustrate the feelings of a number of the respondents serving the local church. Remarked one pastor: "The communication director should be more interested in local affairs of the church and school; more workshops for local PR secretaries and pastors."

Another pastor complained: "Our communication director has not showed any personal interest in small churches or youth programs in the four years I have been in this conference."

Since the responses made by the two communication directors under the category "other" are not critical to an understanding of the trends seen in this section of the survey, they are not discussed here but are instead listed in appendix $P$.

\section{Areas Where the Communication Director Could Use Help, as Well as Give Needed Assistance to Pastors and Conference Presidents}

The pastors indicated their biggest need was for the communication director to "give more attention, information, training, and guidance to local church communication secretaries, pastors, and laymen, through personal visits, workshops, seminars, and other programs of instruction in the communication field" (39.28 percent, table 47).

This plea for more interaction with and training of members of the local church in the art of communication seems to be in line with the thoughts expressed by many of the respondents. A sampling typical of these responses are as follows:

The pastor needs the conference communication director to help train people to function with a degree of efficiency within the local church ministry. That should be his job--the communication area of the local church. 
TABLE 47

WHAT PASTORS WOULD LIKE TO HAVE THEIR CONFERENCE COMMUNICATION DIRECTORS DO FOR THEM, THEIR CHURCHES OR INSTITUTIONS THAT WOULD BE OF MOST IMMEDIATE BENEFIT

\begin{tabular}{lll}
\hline Areas of Need & No. & $\%$ \\
\hline
\end{tabular}

1. Give more attention, information, training, and guidance to local church communication secretaries, pastors, and laymen, through personal visits, workshops, seminars, and other programs of instruction in the communication field.

2. Help create, provide, and/or inform pastors, communication secretaries, and other laymen of resource materials available for the work of communication on the local church level.

3. Develop more individualized PR programs based on demographic studies designed to meet the specific needs of particular church communities.

4. Educate pastors, church communication secretaries, and laymen on how to build a positive image of the church in the community.

5. Continue the fine work he/she is doing.

6. Lighten his multi-department load so he has more time to do the work of communication.

7. Adapt his program to meet the needs of nonEnglish speaking churches and communities.

8. Eliminate the communication department on the local conference level due to its ineffectiveness.

9. Assistance not needed at the present time.

10. Reduce the quantity but not the quality of the materials sent to the local church, adapting and simplifying them for local use.

11. Provide better internal coverage of churchrelated events.

12. Provide more specialized help in communication by the communication director better qualifying himself to do his job through additional studies in communication and through his association with PR professionals. 
In our metro areas there are many smal1 churches without the budgets or knowhow to operate a good PR program. The PR leader for the conference should try to help pool funds and leadership so that these smaller churches can do effective PR work within the cities where they are situated. There are many free services available if the right type of materials were prepared by our conferences and our local churches for a PR outreach to these cities.

We need to put real money into PR for the local churches and the metropolitan areas. We should hire full time help for work involving fair booths, health promotion programs, and media (TV-radio) broadcasts sponsored by the local church. Our conference PR men do well to promote the conference, but in reality they mean nothing to the local church program.

The conference communication director should write a letter to each new church communication secretary explaining in simple terms what they are supposed to do especially those leading out in our smaller churches.

The communication director should have workshops for local church communication secretaries training them on how to be more effective on the local church level.

We would like to have him (the conference communication director) train the journalistic talent of our local churches so as to raise the quality and quantity of our local coverage.

We need to have scheduled seminars around the conference for local church communication secretaries in all areas of PR work.

I wish our communication director would become more involved in the Chicago area news media and teach us how to make contacts by taking us along.

There is much to be done! I feel that proper PR training will be a tremendous help to our communities. Conference communication workshops (interdepartmentally and among our workers) are needed for our ministers, evangelists, and communication secretaries.

The second highest response for this section of the survey

is from those pastors who felt they needed assistance from the communication director in helping "create, provide, and/or inform pastors, communication secretaries, and other laymen of resource materials available for the work of communication on the local church level" ( 8.13 percent, table 47 ). 
Even though the pastors give this category their second highest response, it should be noted that there is a percentage drop of more than 31 percent as compared to their first choice. Some of the thoughts expressed by the pastors relative to this category are as follows:

We need the communication director to help us get material prepared that can be used by the media.

We need media materials for establishing new contacts.

I would like pictures, logos, and other materials made available which the local church could use in advertising.

I wish he (the conference communication director) would let me know just what help is available from his office. Just what kind of resources does he have?

The category rated third by the pastors was their concern for the communication directors to "develop more individualized PR programs based on demographic studies designed to meet the specific needs of particular church communities" (7.22 percent, table 47). Some of their suggestions relative to this response are as follows:

I feel each church needs to be evaluated as to the best way for its membership to use PR in its own situation.

Most of our churches are well under 100 in membership. Most of the materials we get to help us from the PR department are geared for national release. Our papers want news based on what has happened here! Our communication men may be doing this, but it must have missed me.

We need help in communicating effectively to the community we serve, items of community interest.

I think each area must be dealt with through tailor made efforts.

I need our communication director's help in setting up demographic studies so I can realistically know and understand my community's needs. I also need his help in surveying the effectiveness of my existing communication attempts. 
I need help to find out the real needs in my community (a demographic study), so I can design a program to build up our church image in meeting those needs.

The lowest response percentage for this part of the survey was the category pertaining to the "communication director better qualifying himself to do his job through additional studies in communication and through his association with PR professionals" (2.03 percent, table 47). Since the subject of additional training has already been dealt with in another section of the survey, this response should be viewed in light of the response already given rather than isolated to this section alone.

Although the researcher does not think it necessary to make written remarks concerning each of the responses made by the pastors for this section of the survey, they are all listed (table 47) for they are all worth noting. Each category is important, for each represents handwritten response indicative of ministerial needs in the local church.

When conference communication directors were asked what they "would like administrators, pastors, or the church in general to do for them which would be of most immediate benefit to them or their departments," they suggested that more time be given "for the work of the conference communication director by relieving him of his responsibility for additional departments or by giving him additional staff" (20.41 percent, table 48). This concern for sufficient time to do the work of communication is in line with similar thoughts expressed by quite a number of the respondents in other parts of the survey.

Second, the communication directors suggested that there 
TABLE 48

WHAT CONFERENCE COMMUNICATION DIRECTORS WOULD LIKE ADMINISTRATORS, PASTORS, OR THE CHURCH IN GENERAL TO DO FOR THEM WHICH WOULD BE OF MOST IMMEDIATE BENEFIT TO THEM OR THEIR DEPARTMENTS

\begin{tabular}{llll}
\hline Areas of Need & No. & $\%$ \\
\hline
\end{tabular}

1. Provide more time for the work of the conference communication director by relieving him of his responsibility for additional departments or by giving him additional staff.

2. Develop in administrators, pastors, and. laymen, a better understanding of and appreciation for the work of the conference communication director through workshops, seminars, or other programs

3. See that articles, stories, photos, reports, and other materials needed by the department are received on a regular basis and on time.

4. Use present resources to better advantage with additional funds being made available for various projects or goals of the department.

5. Assist conference communication directors in developing a closer and more productive working relationship with pastors and local church communication secretaries.

6. Make additional training opportunities available to the conference communication director. 
be a development among "administrators, pastors, and laymen, of a better understanding of, and appreciation for the work of the conference communication director, through workshops, seminars, or other programs" (14.29 percent, table 48). The emphasis here for a better understanding of the work of the conference communication director seems to be reflected both directly and indirectly in the responses made to other sections of the survey.

The directors' third highest response, similar to other responses seen in the survey, was to request "that articles, stories, photos, reports, and other materials needed by the department be received on a regular basis and on time" (12.24 percent, table 48).

The lowest response given by communication directors as to their most immediate needs is the same as that indicated by pastors. They suggested that the church should. "make additional training opportunities available to the conference communication director" (4.08 percent, table 48). As with the pastors, however, the responses given here should be kept in balance with the main section of the survey dealing with additional educational opportunities suggested for conference communication directors.

The highest response given by conference presidents for this section when they were asked what they needed "right now that their conference communication directors could provide help with," was their need for "better promotion of local church and conferencewide projects or programs through bulletins, church periodicals, or other avenues of approach" (10.26 percent, table 49). They also give the same response percentage (10.26 percent, table 49) to their 
TABLE 49

WHAT CONFERENCE PRESIDENTS NEED RIGHT NOW THAT

THEIR CONFERENCE COMMUNICATION DIRECTORS

COULD PROVIDE HELP WITH

\begin{tabular}{|c|c|c|c|}
\hline & Areas of Need & No. & $\%$ \\
\hline 1. & $\begin{array}{l}\text { Need better promotion of local church and } \\
\text { conference-wide projects or programs through } \\
\text { bulletins, church periodicals, or other avenues } \\
\text { of approach. }\end{array}$ & 4 & 10.26 \\
\hline 2. & $\begin{array}{l}\text { Need the development of more resource } \\
\text { materials made available to pastors and } \\
\text { laymen for their work in communication. }\end{array}$ & 4 & 10.26 \\
\hline 3. & $\begin{array}{l}\text { Need assistance with camp meeting planning } \\
\text { and programs. }\end{array}$ & 2 & 5.13 \\
\hline 4. & Need help with fund-raising activities. & 2 & 5.13 \\
\hline & $\begin{array}{l}\text { Need nothing in particular; he is doing } \\
\text { a good job. }\end{array}$ & 2 & 5.13 \\
\hline 6. & $\begin{array}{l}\text { Need the conference communication director } \\
\text { to be in more constant contact with local } \\
\text { churches, radio, TV, and newspapers concerning } \\
\text { church-related events. }\end{array}$ & 2 & 5.13 \\
\hline & $\begin{array}{l}\text { Need more time for the communication director } \\
\text { to do the work of communication. }\end{array}$ & 2 & 5.13 \\
\hline 8. & $\begin{array}{l}\text { Need demographic and attitude studies of } \\
\text { various communities within the conference. }\end{array}$ & 2 & 5.13 \\
\hline 9. & Need help with "constituency reports." & 1 & 2.56 \\
\hline 10. & Other & 3 & 7.69 \\
\hline
\end{tabular}


need for "the development of more resource materials made available to pastors and laymen for their work in communication." Thus the need for promotion and the development of resource materials seems to be the most important areas of concern for conference presidents. With the exception of the last two, all of the remaining categories register a 4.13 percent response (table 49), apparently viewed as equally important by the conference presidents. Since it has no especial bearing on this part of the survey, the last category, "other," is listed by the researcher in appendix $Q$.

Among the categories receiving the highest response percentages none of the three groups were united on any one category. Two of the groups, however, pastors (8.13 percent, table 47 , item 2) and conference presidents ( 10.26 percent, table 49, item 2) suggested the development of more "resource materials" as being one of the most helpful duties of the conference communication director. Similarly, pastors (39.05 percent, table 47, item 1) and communication directors ( 14.29 percent, table 48 , item 2) emphasized the need for more workshops, seminars, or other programs of instruction in the communication field.

Al though not a11 are registered among the highest responses, al1 three groups of respondents express the need for the communication director to be given more time to do the work of communication (pastors, 3.61 percent, table 47, item 6; communication directors, 20.41 percent, table 48 , item 1 ; and conference presidents, 5.13 percent, table 49, item 7); two of the groups, pastors (6.32 percent, table 47 , item 5) and conference presidents (5.13 percent, table 49, item 5), say that their communication directors are doing a good job 
and that they should continue their work in the same way. Both pastors (7.22 percent, table 47, item 3 ) and conference presidents (5.13 percent, table 49, item 8 ) also agree on the need for the development of "more individualized PR programs based on demographic studies designed to meet the specific needs of particular church communities."

\section{Summary}

The survey results indicate that the majority of conference communication directors hold at least one, and in most cases two conference offices in addition to their responsibilities for the communication department. It also indicates that several of the communication directors hold at least two or more primary offices simultaneously with the communication department. Of the offices held concurrently with communication, the education department is the most common. It is also considered a primary department and very time consuming. The religious liberty department comes next in line to the office of education, but is not considered a primary department or very time consuming. Stewardship is the third department most commonly held by communication directors along with their work in communication, however, the stewardship and youth departments are ranked in second place to education as primary departments. On the other hand the offices of president and youth are listed as being the most time consuming departments next to the department of education.

As reflected in the survey results, both conference communication directors and conference presidents believe that conference 
communication directors are engaged in up to 33 percent more activities in a given month than that perceived by pastors.

Pastors see the "distribution of news releases" as being the primary activity communication directors are involved in during a one month period, with "information, counsel, or advice given the local church communication secretary" in second place, and "church leadership contacted by ami 1" as third.

Communication directors themselves give first place to "office work in article or newswriting" and to "internal coverage via the union church paper." They see "information, counsel, or advice given to the local church communication secretary" and the "distribution of news releases" as being the second two areas of activity they most frequently engage in during a given month. The third activity is their "contacting of church leadership by letter."

Conference presidents see "internal coverage via the union paper" as the activity communication directors are the most regularly involved in, with "information, counsel, or advice given the local church communication secretary" as second, and "distribution of news releases," third. Even though the three groups of respondents disagree on the activities given first place, all agree that second place should go to "information, counsel, or advice given local church communication secretaries."

Another area that received high responses from all three groups concerns the "distribution of news releases." It should also be noted that all three groups of respondents give low percentage responses to the communication director's invovement in $P R$ interests of denominational institutions. 
The majority of pastors, communication directors, and conference presidents see the primary place of the local conference communication director in "finishing" God's work as being "indirect evangelism in terms of image building." Although there is an average drop of 27.55 percent, all three groups give their second highest response to "evangelism in terms of seed-sowing." Even though the response percentages are low, there are some from each group of respondents who indicate that the work of the communication director is "not evangelism in any sense." Of those who give this response, conference presidents rated highest, communication directors second, and pastors third.

When the different age groups of respondents are examined, a number of variations concerning the place of the conference communication director in "finishing" God's work can be observed.

Although the balance of percentages is not completely equal in all cases, pastors, ages 20 to 29 and 30 to 39 ; communication directors, 30 to 39 , and 50 to 59; and conference presidents 60 plus, give approximately equal responses to the work of the communication director as being "evangelism in terms of seed-sowing" and "indirect evangelism in terms of image-building."

Pastors 40 to 49,50 to 59 , and 60 plus, and communication directors 40 to 49 , and 60 plus show almost twice as great (three times for communication directors 60 plus) a response for "imagebuilding evangelism" as they do for "seed-sowing evangelism." Conference presidents, ages 40 to 49 , take a similar view with the exception that their response is four times as great for "imagebuilding evangelism" as it is for "seed-sowing evangelism." 
There were no responses given by conference presidents, ages 20 to 29 , and only one response by a communication director 20 to 29 who indicated "image-building evangelism" as his choice.

Of all the respondents or age groups, only the conference presidents, ages 30 to 39 , give priority to "seed-sowing evangelism" over "image-building evangelism."

Eight pastors, ages 20 to 29,30 to 39 , and 40 to 49 ; one communication director, 60 plus; and two conference presidents, 40 to 49 , and 50 to 59 , viewed the work of the communication director as "not being evangelism in any sense."

The survey also indicated that communication directors themselves feel a much stronger need for additional "professional or specialized training" than suggested by either pastors or conference presidents. This is verified by the fact that communication directors give their highest responses to fifteen out of the nineteen categories listed as additional training suggestions in this section of the survey. Pastors were highest in only two of the nineteen categories as were conference presidents. Relative to the other groups of respondents, pastors give their best response to "soul-winning methods" and "counseling;" whereas conference presidents indicate as their choice "workshop or seminar training and design" and fund-raising methods."

Focusing on the educational needs of the conference communication director as perceived by the respondents within each group, pastors give their highest response to "advertising methods," then to "journalism," and last to "demographics;" whereas communication directors indicate their need for additional training 
in "advertising methods," "photography," and "journalism" in that order. Conference presidents list "journalism" as their first choice, next "advertising methods," and finaliy "workshop or seminar planning and design."

Al though the order and percentages may vary, all three groups of respondents give priority to "advertising methods" and "journalism" as important areas in which communication directors should receive additional training.

The general trends reflected in this section of the survey dealing with the "relative importance of the work of the conference communication director" show all of the respondents giving either a very low response to the "optional" category ("optional: a good department to have but could do wi thout it on the local conference leve1") or no response at all. Even though their responses are still relatively low, all of the respondents--pastors, communication directors, and conference presidents--give their next highest response to that view which sees the communication department as being "less important than other departments of the conference, but essential." The highest response for all three groups indicates their understanding of the department as being "approximately equal in importance to other conference departments." The next category, which pictures the department as being "more important than some departments, but less important than others," shows a drop in percentage for all of the respondents. Another response percentage drop is indicated by all groups for the final category which proposes that the communication department is "the most important department in the conference." 
When the different age groups are considered, some interesting variations can be seen. The general trend for pastors, ages 20 to 29,30 to 39,50 to 59 , and 60 plus; communication directors 30 to 39,40 to 49 , and 60 plus; and conference presidents 40 to 49 are similar, with some minor variations, to that of all the groups as a whole (figure 16). In other words there is a low response for the "optional" category, followed by a somewhat higher response for "less important" with the highest response being given to the "equal importance" category. From there the responses taper off through "more important" to a low in the "most important" category. Pastors 40 to 49 generally follow the same pattern as those of their fellows in the other age groups (figure 16) with the exception that they register a slightly higher response for "optional" than they do for the "less important" category.

Communication directors and conference presidents, ages 50 to 59 , also follow the same general pattern as observed in a11 the groups (figure 16 ) with the exception of some variation seen in the "optional" and "less important" categories. However, they give their highest response to the "more important" category instead of to "equal importance" as do the other respondents.

There is only one response given from a communication director 20 to 29. He sees the communication department as being "more important" than some conference departments but less important than others. There are, however, no responses from conference presidents for this age group.

Each of the three conference presidents, ages 30 to 39 , give their responses to different categories--"optional," "less 
important," and "more important." Conference presidents 60 plus give only two responses: a low to "optional," and a high to the "equal importance" category.

As to educational background, the survey shows that the majority of the respondents (pastors, communication directors, and conference presidents) majored in theology while in college. Although the order varied and percentagewise is far below the responses given to theology, the survey also indicates that a number of respondents from al1 three groups surveyed, majored in "history," "education," and "languages." None of the conference presidents, eight of the pastors, and only three of the communication directors majored in communication in college. The survey percentages for the areas of emphasis for those who either majored or minored in communication are quite low, due apparently to the fact that few were involved in communication in college.

The highest response percentages for all groups of respondents who received some training in communication is seen in the postgraduate job-related training section of the survey. Here it is found that pastors are the highest in speech, communication directors in "journalism" and "PR," and conference presidents highest in "radio-TV" work. However, as previously noted, in terms of percentages communication directors and conference presidents are very close to each other in these three categories ("journalism, "PR," and "radio-TV"). When asked what experience they had had in fields "related to" communication, pastors give their highest response to their experience as "church pastors;" whereas communication directors registered their highest response for their experience as 
communication directors. Although the percentages varied, all three groups of respondents said that their past or present experience as "conference communication directors" and in "radio-TV" work were factors in the experience gained in the communication field. The section of the survey dealing with the degree of acquaintance pastors have with their conference communication directors shows that most pastors are "well acquainted with him." However, this is partially modified by nine pastors responding under the category "other" who said they were "well acquainted with their communication director, but had received little assistance from him." There were a number of others who said they received assistance only when they asked for it. It was also noted that when the response percentages for the first three categories ("don't know who he is;" "know who he is, but have never met him;" "have met him, but have received little if any assistance from him") are added together along with the nine responses just mentioned ("other" category), the resultant percentage seems to indicate a reserved attitude to the work of the conference communication director on the local level.

According to the communication directors the areas of communication they concentrate on the most frequently during a typical three month period are "writing," "photo coverage of churchrelated events," "preparation of resource and promotional materials," and "editing," in that order.

Regarding areas where the local conference communication director himself could use help, as well as give needed assistance to pastors and conference presidents, the survey indicates that none 
of the three groups of respondents were fully agreed on any one of the more important areas of need suggested by the respondents; however, there were some "need areas" with, in most cases, lower response percentages where two or more of the groups were in agreement. For instance, the only area of need where all three groups give essentially the same response is in their desire to see that the "communication director has more time to do the work of communication." Two of the groups, pastors and conference presidents, suggest that the communication director become more involved in the development of "resource materials;" whereas communication directors and pastors join together in emphasizing the need for more "workshops, seminars, or other programs of instruction." On the other hand, pastors and conference presidents see a need for the development of "more individualized PR programs based on demographic studies designed to meet the specific needs of particular church communities." Two of the groups, pastors and conference presidents, felt that their communication directors were doing a good job and had nothing special to suggest.

Taken as a group, according to the survey results, the greatest area of need for pastors is for the communication director to "give more attention, information, training, and guidance to local church communication secretaries, pastors, and laymen through personal visits, workshops, seminars, and other programs of instruction in the communication field." Conference communication directors give their highest response to the suggestion that more time be given "for the work of the communication director by relieving him of additional departments or by giving him additional 
staff." Conference presidents express their need to see the communication director give "better promotion to local church and conference-wide projects or programs through bulletins, church periodicals, or other avenues of approach." They also give the same response percentage to their suggestion that the communication director assist in "the development of more resource materials made available to pastors and laymen for their work in communication."

\section{Analys is}

The following analysis of the work of the conference communication director in the United States as reflected in the response results of the survey should be helpful in determining certain problem areas or trends of this department as it now operates within the Seventh-day Adventist Church.

From the responses given by the communication directors regarding the offices they care for in addition to their work with the communication department, it appears that in most cases their responsibilities far exceed the time needed to meet these responsibilities. This is especially true for those departments held concurrentiy with communication which are considered primary departments and thus quite time consuming. One such department which, according to the respondents, communication directors most commonly care for along with their own department is the Department of Education. Even though it is one of the most common offices held simultaneously with communication, it appears, at least to this researcher, to also be the office most incompatible with the department of communication due to the reasons just stated. 
Since conference presidents and communication directors indicate they believe conference communication directors are engaged in up to 33 percent more activities in one month than that perceived by pastors, it would appear that the effectiveness of the communication department on the local church level, at least from the pastoral view, is considerably less than that perceived by administrators. These perceptions, whether valid or invalid, would seem to have some bearing on the overall effectiveness of the department on the local level.

With a majority of those surveyed (pastors, communication directors, and conference presidents) suggesting that the work of the conference communication director is "indirect evangelism in terms of image building," as opposed to "seed-sowing evangelism," it appears that most of the respondents see the work of the communication director as more of a framework for or reinforcement to evangelism rather than intrinsically evangelistic in nature. Those who give especially strong responses to this view (at least twice the response as for the next highest category) are pastors 40 to 49,50 to 59 and 60 plus (this group gives three times the response) and communication directors 40 to 49 and 60 plus. Conference presidents 40 to 49 register four times as great a response for "image-building evangelism" as they do for "seedsowing."

Even though the percentages are an average of 27.55 percent lower, there is still a relatively large group who see the department as being "evangelism in terms of seed-sowing." This group seems to sense a closer, more intricate relationship between 
the work of communication and evangelism. They apparently see communication as being more a part of than an addition to evangelism. Out of all the respondents surveyed, only conference presidents, ages 30 to 39 , places "seed-sowing evangelism" above "image-bui d ding."

The survey also indicates that a majority of the pastors. 20 to 29 and 30 to 39 ; communication directors, ages 30 to 39 and 50 to 59, and conference presidents 60 plus, give similar response values to both "image building evangelism" and "seed-sowing evangelism." This group apparently gives equal weight to these two aspects of communication as they relate to evangelism.

Although the percentages are low, the fact that there are some from each group who say the work of the communication director is "not evangelism in any sense" seems to indicate a dichotomy in some minds regarding the relationship between communication and evangelism. The fact that there was one communication director (60 pius) who checked this category may add additional weight to this position. It should also be noted that most of these negative responses are given by respondents in the older age brackets 40 to 49,50 to 59 , and 60 plus. Perhaps these responses are indicative of a gradual disillusionment or disenchantment with the conference department of communication by this group over the years. As previously mentioned, conference communication directors themselves were highest in fifteen out of the nineteen categories suggested for additional professional or specialized training needed by communication directors. Since, according to the survey, most of the training that communication directors have received is mainly 
in the area of theology or religion, such a response could indicate a sincere desire on the part of communication directors to have more opportunities for education in the communication field. Among those areas that they would most likely want to concentrate on are advertising methods and journalism, the two categories of communication given the strongest support by the three groups of respondents.

For the survey section dealing with the "relative importance of the work of the conference communication director," the majority of the respondents from all three groups indicate that in their view, the communication department was "approximately equal in importance to other conference departments.". All five ministerial age groups, as well as communication directors 30 to 39,40 to 49 , and 60 plus and conference presidents 40 to 49 , and 60 plus, take this position. Although this view is accepted by the majority of respondents, to some extent it is counterbalanced by those from all three groups who consider the department either "optional" or "less important" on the local level. When seen together, these two views result in a combined response which seems to some extent to call into question the credibility or effectiveness of the communication department on the local level. Even though none of the communication directors checked the "optional" category, the fact that four of them did check the "less important" column adds additional weight to this position.

Since conference presidents give the highest response for a11 three groups to the "more important" category, and communication directors, the highest to the "most important" column, it would 
seem that there is, at least from the administrative level, a more positive view towards the work of the communication director than that indicated by pastors. Those communication directors and conference presidents who, at least in part, support this view (they give a high response to "more important" but low for "most important") are in the 50 to 59 age bracket. However, some of these are among those who qualified their responses by suggesting that the department was not now the "most important" (or "more important") department in the conference but could be the most important if it were perceived as such and organized accordingly. The survey also showed that eight of the pastors, none of the conference presidents, and only three of the communication directors majored in communication in college. The majority of pastors, communication directors, and conference presidents majored in theology or religion. With this rather weak communication background, it is understandable that communication directors themselves give the highest response in the survey to fifteen out of the nineteen category suggestions for additional training in the communication field. Most of the experience gained by communication directors was "post-graduate job-related training" in communication. Here communication directors were highest in "public relations," with conference presidents a close second. In most post-graduate categories the survey showed little difference between the experience gained by conference presidents and that of communication directors. This could be, however, due to what this researcher senses is a lack of understanding of the true dimensions or scope of communications, as indicated by the wide variety of post-graduate 
"areas of communication" suggested by the respondents. It would seem that this factor to some extent negates or at least narrows the "actual experience" gained through "post-graduate, jobrelated training" received by communication directors.

Even though a majority (63.66 percent, table 45) of the pastors surveyed said they were "well acquainted" with the conference communication director, there were still a relatively large group of pastors (30.47 percent, table 45) who seemed to reflect a more reserved attitude toward the work of the communication director on the local level. This was seen by the combined responses of the first three sections ("don't know who he is," "know who he is but have never met him," and "have met him, but have received little if any assistance from him") and the nine pastors under the "other" category who also indicated some reserve about the communication director. This reserve, perhaps based on observance, appears to be in harmony with the results of other parts of the survey.

According to the survey results, not a17, but a substantial percentage of the activities conference communication directors are involved in during a typical three month period are office oriented, whereas those that are more directly people oriented are found on the lower end of the percentage scale. This could indicate the need for a revised program, making the department more peopleconscious in its approach to communication.

According to the survey, one of the greatest needs pastors have, which is apparently not being met as it could be, is for a more focused approach by communication directors in training 
pastors, local communication secretaries, and laymen in the various areas of communication. On the other hand communication directors see "time" as being their biggest need--time needed to effectively administrate the department of communication without becoming bogged down with the responsibilities of additional departments. This problem of the communication director having adequate time to do the work of communication is the only need area in this section of the survey agreed upon by respondents from all three groups. It also surfaces in other sections of the survey and seems to be one of the larger handicaps to an effective communication program on the local level. The most important need area indicated by conference presidents for the services of communication directors is concerned with the "promotion" of various church programs and projects through church bulletins, periodicals, or other internal channels of communication. That this is generally being done can not be denied, but perhaps, according to conference presidents, some improvement might be in order. 
CHAPTER VI

\section{RECOMMENDATIONS BASED ON RESEARCH}

\section{FINDINGS}

Based on the responses to the survey used in connection with this study of the conference communication director and the insights gained through interview, research, and experience, the researcher makes the following recommendations:

1. According to the survey, the majority of communication directors hold one or more conference offices in addition to their responsibilities with the communication department. In most cases these responsibilities far exceed the time needed to care for them adequately. Since the work of the communication director, when understood in light of this study, is to be considered a full-time job, and since the communication directors themselves indicate their need for more time to effectively administrate the department of communication, the researcher therefore recommends that the communication director be encouraged to care for his department alone. If, however, due to budgetary problems or for other reasons, he is asked to care for one or more departments in addition to communication, the administration should make sure that he is not given the responsibility for any of the primary departments, such as the departments of education, youth, stewardship, or the office of president. 
2. The survey also indicates that communication directors and conference presidents see communication directors as being engaged in up to 33 percent more activities in one month than that perceived by pastors. From these findings, it is apparent that pastors do not receive the assistance from their communication directors that the communication directors themselves and conference presidents seem to think they do. Perhaps this is why the most urgent need of pastors, according to the survey, is for communication directors to "give more attention, information, training, and guidance to local communication secretaries, pastors, and laymen, through personal visits, workshops, seminars, and other programs of instruction in the communication field" (39,05 percent, table 47).

Based on this information as reflected in the survey, the researcher recommends that conference communication directors design their programs in such a way that their activities will "speak for themselves" in terms of the professional guidance and practical assistance they are able to give in meeting the specific needs of the pastors and their churches on the local level.

3. Even though there is a relatively large group of pastors, communication directors, and conference presidents surveyed who suggest that the work of the communication director is "seed-sowing evangelism" (46.33 percent, table 18), the majority see his work as being that of "indirect evangelism in terms of image-building" (76.08 percent, table 18). It therefore seems that most of the respondents view the work of the communication director as more of a framework for or reinforcement to evangelism rather than being a part of the evangelistic process itself. This view is further 
reinforced by a number from each group who did not see the work of the communication director as being "evangelism in any sense."

It thus appears to the researcher that there is a general lack of understanding among all groups of respondents as to the important place of communications in the evangelistic continuum of the church. The researcher therefore recommends that conference communication directors, who themselves are aware of the evangelistic potential of communications, lead out in a gradual process of re-educating administrators, pastors, and laity as to the place for and importance of communications in an evangelistic context. This can be accomplished, at least in part, by communication directors presenting a series of lectures and sermons, or writing a series of articles for church periodicals on the subject.

4. According to the survey, the educational background of conference communication directors is almost identical to that of pastors and conference presidents. Approximately 80 percent of a 11 of the respondents from the three groups had their training in theology or religion.

Most of the training or experience of communication directors in communication was gained through "post-graduate job-related training." However, the researcher finds this training questionable due to the rather "broad spectrum" of post-graduate "communication areas" suggested by the communication directors. This seems verified by the fact that conference communication directors themselves are higher than either pastors or conference presidents in fifteen out of the nineteen categories noted in the survey concerning the professional or specialized training needed by communication directors. 
Because of the desire of communication directors to gain additional training in communication, and the church's need to have well-trained, professional communication personnel on all levels of church administration, the researcher suggests that the church, in general, and the conference administrators, in particular, give study to providing additional educational opportunities to communication directors in order to foster a higher level of professionalism within that department. This can best be accomplished by giving communication directors the opportunity of associating with PR professionals, by taking public relations courses at night school, or by attending denominational, inter-denominational, or nondenominational workshops, seminars, or conventions on communication. Subscriptions to popular public relations journals, and cassette or video tape clubs dealing with the principles and practice of communications would also be helpful.

In addition, the researcher also recommends that the officers of the conference and the conference committee be more concerned and selective when choosing a person to head up the communication department. Although spiritual qualifications are essential, professional qualifications should be the main basis of employment.

5. The survey also indicates that a majority of the respondents see the communication department as being "approximately equal in importance to other conference departments" with a number from each group saying it "could be" the "most important" department if it were perceived as such and organized accordingly. However, these views are counterbalanced to some extent by those from all three groups who consider the department either as "optional" 
(6.90 percent) or less important (14.64 percent) than other departments of the conference.

The general impression conveyed to the researcher from this and other sections of the survey, coupled with his own research, produces a rather indefinite, hazy picture of the department as to its place and importance in the church. It appears to the researcher that this same indefiniteness or haziness has been carried into the reality of how the department operates or does not operate in many conferences today. The researcher would therefore recommend that each conference, in consultation with communication specialists, give special study to the specific needs of the conference and then with qualified leadership in the communication department, see that those needs are met.

6. Even though a majority of the pastors say they are wellacquainted (63.66 percent) with the communication director, indications from the survey as a whole show that in many of the conferences, inspite of this acquaintance, relatively little assistance in communications is given to the pastors. The researcher would therefore recommend that all conference communication directors be encouraged to keep in regular contact with the pastors and their churches through personal visits, by phone, through personal correspondence, and by involving them in a variety of communication workshops, seminars, or other PR activities designed to meet their particular communication needs. By so doing, the communication director will be in a much better position to assess, guide, and assist the pastors with their needs in this area.

7. Results from the survey also indicate that a high 
percentage of the activities that conference communication directors are involved in during a typical three-month period are office oriented rather than people oriented. These activities include writing (73.47 percent, table 46), photo coverage of church-related events (65.31 percent, table 46), preparation of resource and promotional materials (26.53 percent, table 46), and editing (14.29 percent, table 46).

To some degree, this emphasis is understandable, for according to conference presidents, whose influence is important as regards the operational dimension of the department, one of the communication director's most important responsibilities is his promotion of various communication activities of the conference. However, since effective communication involves a close working relationship with people, and since, according to the survey, the greatest need of pastors is to have the communication directors personal assistance in the local church, the researcher therefore recommends that all conference communication directors revise their programs where necessary in order to make them more people centered in harmony with good communication principles.

8. As a result of this study, the researcher also recommends that all communication directors be members of their respective conference committees, due to the importance of their work as coordinators for all conference departments in the evangelistic outreach of the church, and because of their need to be kept in constant contact with the decisions, plans, and projects of the conference.

9. Furthermore, since most conference communication 
departments are different to some extent from each other, the researcher also recommends that each conference undertake a study of its own communication department in order to assess its strengths and weaknesses in light of good communication principles and practice, and in order to see that the work of the department is designed to meet the evangelistic needs, goals, and long-range objectives of the conference.

10. No matter how sound the strategy appears to be, it is the concern of this researcher that conference communication directors take the initiative in evaluating and measuring programs of evangelism as to their effectiveness in reaching the goals they were designed to reach. The researcher therefore recommends that program measurement become a vital part of every conference communication strategy, enabling the church, under the Spirit's guidance, to effectively, efficiently, and intelligently carry out its work of evangelism.

\section{Conclusion}

The results of the study clearly indicate that local conference presidents, pastors, and communication directors themselves are relatively uncertain about the role and evangelistic value of the communication director in the local conference.

This uncertainty appears to emerge from two primary causes: (1) the lack of time available to communication directors to do their work adequately, since most oversee one to three other departments as well, and (2) the lack of previous training for their position which in some respects tends to hinder their perceived and 
actual effectiveness in certain areas in which they otherwise would be considered experts (such as teaching pastors how to write for the news media or how to design radio or television spots).

The researcher concludes that in order for local conference communication directors to serve their conferences with efficiency and effectiveness, they should be previously well-trained and, when called to this office, free from the administrative responsibilities involved in overseeing additional departments. 
A P P $N D I X$ 


\section{APPENDIX A}

CHART ON THE SPIRITUAL DECISION PROCESS 
The Spiritual Decision Process

The Complete Spiritual Decision Process Model Showing the Stages of Spiritual Growth

\begin{tabular}{|c|c|c|c|}
\hline \multirow{2}{*}{$\begin{array}{l}\text { GOD'S } \\
\text { ROLE } \\
\begin{array}{l}\text { General } \\
\text { Revelation }\end{array}\end{array}$} & \multicolumn{2}{|c|}{$\begin{array}{l}\text { COMMUNICATOR'S } \\
\text { ROLE }\end{array}$} & \multirow{2}{*}{$\begin{array}{l}\text { MAN'S } \\
\text { RESPONSE } \\
\text { Awareness of } \\
\text { Supreme Being }\end{array}$} \\
\hline & & -8 & \\
\hline Conviction & \begin{tabular}{|} 
Proclamation \\
Calt for \\
Decision
\end{tabular} & $\begin{array}{l}-7 \\
-6 \\
-5 \\
-4 \\
-3 \\
-2 \\
-1\end{array}$ & $\begin{array}{l}\text { Some Knowledge } \\
\text { of Gospel } \\
\text { Knowledge of } \\
\text { Fundamentals of Gospel } \\
\text { Grasp of Personal } \\
\text { Implications of Gospel } \\
\text { Positive Attitude } \\
\text { Toward Act of Becoming } \\
\text { a Christian } \\
\text { Problem Recognition } \\
\text { and Intention to Act } \\
\text { Decision to Act } \\
\text { Repentance } \\
\text { and Faith in Christ }\end{array}$ \\
\hline REGENERATIC & ION & & NEW CREATURE \\
\hline Sanctification & $\downarrow_{\text {Cultivation }}$ & $\begin{array}{l}+1 \\
+2 \\
+3 \\
\bullet \\
\bullet \\
\bullet \\
\text { Eterr }\end{array}$ & $\begin{array}{l}\text { Post Decision } \\
\text { Evaluation } \\
\text { Incorporation } \\
\text { Into Church } \\
\text { Conceptual and } \\
\text { Behavioral Growth } \\
\text { - Communion With God } \\
\text { - Stewardship } \\
\text { - Internal Reproduction } \\
\text { - External Reproduction }\end{array}$ \\
\hline
\end{tabular}

SOURCE: James F. Engel, Contemporary Christian Communications (Nashville, TN.: Thomas Nelson Inc. Publishers, 1979), p. 83. 


\section{APPENDIX B}

\section{PRE-QUESTIONNAIRES SENT TO FIFTY}

DENOMINATIONAL WORKERS 
1. What in your understanding is the role of the conference communication director in the work or mission of the church?

2. To what extent is the role of the conference communication director involved in the evangelistic outreach of the church on the local level?
1. What in your understanding should be the role of the conference communication director in the work of the church?

2. To what extent should the conference communication director be involved in the evangelistic outreach of the church on the local level?
3. What are the needs of the conference communication director?
3. Are the needs of the conference communication director being met? 
4. In what way is the conference communication director meeting the needs of the local pastor?

5. Do you see any problems of role conflict when a conference communication director finds himself responsible for other departments in addition to his own?
4. In what way should the conference communication director be meeting the needs of the local pastor?

5. What are some additional areas that you feel should be explored as to the work and ministry of the conference communication director in his relationship to the local church? 
APPENDIX C

GENERAL CONFERENCE ROLE DESCRIPTION FOR CONFERENCE COMMUNICATION DIRECTORS 
GENERAL CONFERENCE ROLE DESCRIPTION FOR

CONFERENCE COMMUNICATION DIRECTORS

Responsibilities to the Conference

1. Maintain current lists of all news media in your conference and make frequent contact with those in your immediate area, establishing yourself as the Adventist information source for the conference headquarters.

2. Know your nearby service clubs and other organizations, which ones may appreciate occasional Adventist program talent, and work with them in providing such talent.

3. Report news originating in conference office, such as announcement of official actions, new elections and appointments and development plans.

4. Cover or supervise coverage of regional and conference-wide events such as camp meeting, youth rallies, Pathfinder jubilees, and disaster-aid activities, including photo coverage as well as reporting.

5. Coordinate conference presentation of public exhibits.

6. Work for the placement of denominationally produced public service and syndicated programs and columns wherever possible, seeking to secure free time or space.

7. Arrange for broadcast and Bible correspondence school rally days and graduation exercises.

8. Assist conference evangel ist in preparing way for evangelistic meetings and help local church communication secretary with coverage.

9. Assist with the preparation of brochures, bulletins, audio-visual communications, and advertising.

10. Care for public relations problems which might develop on the conference or local church level.

11. Maintain photo and biographical files on conference and institutional leadership.

12. Cooperate in an effective follow-up ministry for interests generated by broadcasts and Bible correspondence school courses.

13. Be informed as to official plans and departmental projects, so that you can assist in areas of communication.

14. Pass on to union publication reports on church and/or conference activities. 
15. Cooperate with other conference departments in promotion of projects touching the public.

16. Help in preparation of reports by the conference to constituency meetings.

\section{Responsibilities to the Local Church}

1. Encourage election of communication secretaries in all churches, and in large churches, a communication committee.

2. Develop an understanding of each church communication secretary's local situation.

3. Encourage regular reporting to conference on forms provided for church communication secretary.

4. Assist church communication secretaries with local problems and media contacts and with events of unusual nature such as church dedications, evangelistic series.

5. Hold workshops in communication, photo journalism, editorial and writing with assistance from the union and/or General Conference.

6. Sent to church communication secretary practical suggestions and news releases particularly adapted to specific area.

7. Alert communication secretaries of newsworthy visitors or events affecting their churches.

8. Promote communication department programs.

9. Keep in close touch with church communication secretaries via monthly bulletins, telephone and personal visits.

10. Make sure every church communication secretary is 7 isted with the union conference and General Conference Communication Department, and that he receives 211 helps issued from these offices as well as yours.

11. In metropolitan areas with several churches, organize church communication secretaries into a communication committee, so that one central secretary chosen by the group handles news to metropolitan papers on concurrent events. Other secretaries will work with their neighborhood papers on such stories. They may go direct to metropolitan papers, however, on stories pertaining only to their church.

12. Encourage activities that will increase enrollments in Bible correspondence courses.

13. Promote church offerings devoted to broadcasting and Bible correspondence schools. 
14. Promote local church participation in community events and assist with materials and suggestions in such activities as exhibits at fairs and floats in parades.

15. Assist local pastors in their preparation for, and involvement with, local broadcasts.

16. Send photos and release information on conference and Genera? Conference staff scheduled to speak at local church, one week prior to the date scheduled.

\section{Responsibilities to Conference Institutions}

1. Encourage institutions, such as large schools and medical institutions, to appoint someone to handle public relations responsibilities.

2. Make yourself available to help institutional public relations officer in getting started and on special occasions.

3. Serve upon invitation on special events committees of the institution to help in public relations planning.

4. Aid in problems involving community, church or professional opinion.

5. Encourage and aid in planning for institutional participation in exhibits, parades, etc., if assistance is requested.

6. Be prepared when called upon to help in meeting internal public relations problems.

7. Initiate and work with institutional public relations officers in projects of joint interest to institution and church.

\section{Responsibilities to the Union Conference}

1. Send quarterly reports to union communication director not later than the 20th of the month following the end of each quarter.

2. Cooperate with union communication director on events or plans likely to affect areas beyond your field as well as in union sponsored events.

3. Pass on to union communication director any reports on unusual communication results, activities, or news coverage with a copy to the General Conference Department.

4. Report to union communication director changes and additions of church communication secretaries. Send copy of such changes and additions to General Conference Communication Department unless other arrangements arrangements have been made. 
5. On plans, contacts, or other matters of national significance local conference should report to union as early as possible with carbon to General Conference Communication Department. In emergency situations contact by phone the union office, the local and union to decide by mutual agreement which shall phone the General Conference Communication Department. If union director cannot be reached, you should contact the General Conference office direct. Work on the matter should have the cooperation of local, union, and General Conference when of sufficient significance. 
APPENDIX D

LIST OF ANDREWS UNIVERSITY FACULTY CONSULTED 
FACULTY CONSULTATION

Below are the names and positions of thirty Andrews University faculty members who were sent copies of a preliminary draft of the survey instrument. An asterisk $\left(^{*}\right)$ has been placed beside the names of those who responded to this request for assistance.

*George Akers, Ed.D., Professor of Religious Education

Luanne J. Bauer, Ph.D., Assistant Professor of Communication

David H. Bauer, M.A., Vice President for Development and PR

Ivan T. Blazen, Ph.D., Associate Professor of New Testament and Biblical Theology

*Thomas H. BT incoe, Th.D. , Professor of Theology

LeRoy H. Botten, M.S., Assistant Professor of Information Science

*EIden M. Chalmers, Ph.D., Professor of Pastoral Care and Nurture

* Car 7 Coffman, M.Div., Professor of Religion

Robert J. Cruise, Ph.D., Associate Professor of Measurement and Evaluation

*Wilfred G.A. Futcher, Ph.D., Professor of Measurement and Evaluation

*lyndon G. Furst, Ed.D., Associate Professor of Educational Administration

* Colleen S. Garber, M.A., Instructor in Communication

* William E. Garber, Ph.D., Assistant Professor of Journalism

*Elaine Giddings, Ph.D. , Professor of Communication

*Roy E. Graham, Ph.D., Provost

*Fritz Guy, Ph.D., Professor of Theology

*Gerhard F. Hasel, Ph.D., Professor of 01d Testament and Biblical Theology

*Robert M. Johnston, Ph.D., Associate Professor of Theology

*Arnold A. Kurtz, Ph.D., Professor of Church Leadership and Administration

${ }^{*}$ C. Mervyn Maxwe11, Ph.D., Professor of History

* Robert D. Moon, Ph.D. Professor of Teacher Education

Raymond Moore, Ph.D., Director, Hewitt Research Center

*Chris J. Robinson, M.A., Public Relations Director

*Russel1 L. Staples, M.Div., Associate Professor of Mission

Allen Steele, M.A., Station Manager, WAUS-FM

* Kenneth Strand, Ph.D. , Professor of Church History

*Abraham Terian, Dr. Theo1., Associate Professor of Inter-testamental and Early Christian Literatures

*Ed Turner, Ph.D., Assistant Professor of Preaching and Pastoral Care

* Steven D. Vitrano, Ph.D., Professor of Preaching and Field Education

Robert A. Williams, Phd., Professor of Educational Psychology and Counseling 
APPENDIX E

LETTER ACCOMPANYING PRE-QUESTIONNAIRE 
Andrews University Berrien Springs, Michigan 49104 (616) 471-7771 February 21, 1980

Elder Smuts van Rooyen

601 Bluff View Drive

Berrien Springs, MI 49103

Dear Smuts:

According to the schedule, I am supposed to complete requirements for the Doctor of Ministry degree by early August. However, unless I can count on your assistance, which August that will be might be up for question. Let me explain.

As a part of my studies here at Andrews, I am required to do some research on a doctoral project of my choice. The project I have chosen centers on an analysis and role description of the local conference communication director and his evangelistic role in the Adventist Church. Some important practical information needed for this project will be gained through interview and questionnaire. And this is where you come in.

Enclosed with this letter are a few questions which, along with your response, would greatly assist me in the development and design of the interviews and questionnaires to be used in this project. If you could take just a few minutes to send me your suggestions in answer to these questions, hopefully within a day or two, it would be greatly appreciated. No typing is necessary. In order to save your time and mine, hand-written notes would be adequate.

Thanks in advance for your prayers, and quick response to this request.

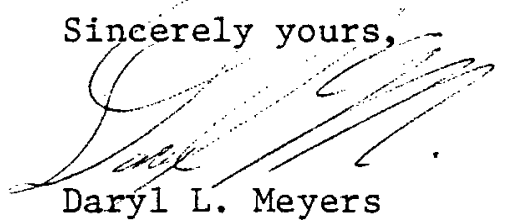

Dary 1 L. Meyers

Seminary Student

D. Min. Program

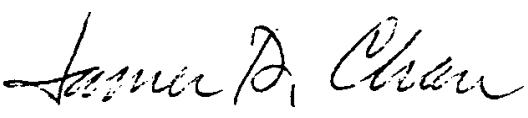

James David Chase Assistant Professor of Broadcast Evangelism

Enclosure 
APPENDIX F

\section{LETTERS OF CORRESPONDENCE}

REGARDING QUESTIONNAIRE 


\title{
Andrews University Berrien Springs, Michigan 49104 (616) 471-7771
}

\author{
Dary 1 L. Meyers \\ Maplewood, C-69 \\ Berrien Springs, \\ Michigan 49103 \\ February 14, 1980
}

Elder James E. Chase

General Conference of SDA

Communication Department

6840 Eastern Ave., NW

Washington, D.C. 20012

Dear Elder Chase:

I must begin this letter by thanking you for the support you have already given me on my doctoral project concerning the study of the local conference communication director. As I am sure you are well aware, I am now getting more and more involved in the project. Hopefully, with God's help and some earnest effort, my project should be completed by June or July of this year.

There are still some materials and information needed for my research which, if you had access to them and could send them my direction, would be extremely helpful. They are as follows:

1. an outline of the present role or responsibilities

of the local conference communication director.

2. a present up-to-date list of communication directors and their addresses in North America.

3. a list of all North American conference presidents.

4. the names and addresses of all licensed and ordained ministers in North America, and

5. a 1980 Seventh-day Adventist Yearbook.

I realize the necessity in any administration of having a certain amount of red-tape to go through, but if in this case you found it possible to "cut a few corners" in getting the above items to me as quickly as possible, I would be very grateful. Kindly let me know the cost for these materials and the mailing expenses and I will get a check off to you immediately.

Thanks once again for your prayers and interest in this project.

Sincerely Yours,

Dary1 L. Meyers

Andrews University 
Andrews University Berrien Springs, Michigan 49104 (616) 471-7771

June 3,1980

James Hayward

Michigan Conference

P.0. Box 19009

Lansing, MI 48901

Dear Brother Hayward:

I am at present involved in a rather important study here at Andrews University which centers on the work and ministry of our conference communication directors throughout the United States.

Most of the materials needed for this research project are being derived from a questionnaire sent to a random sampling of our Adventist pastors across the U.S. Due to the fact that many of our ordained men are serving in a variety of capacities other than pastoral work, it is of special importance that we acquire up-to-date lists of our ministers who are actually involved in a pastoral-church ministry.

If you would be so kind as to send us - as quickly as possible a list of the ordained and licensed ministers in your conference who are presently serving as pastors of churches or districts, we would be extremely grateful.

Thanks so much in advance for your help.

Sincerely yours,

Daryl L. Meyers

D.Min. Program

enc. self-addressed

envelope enclosed 
APPENDIX G

COVER LETTERS FOR SURVEYS 
April 4, 1980

\section{Dear fellow worker:}

One of the greatest needs of our church today is the Spirit's guidance in exploring effective and efficient ways of communicating the gospel message to modern man. To meet men in any condition, wherever they may be found. To apply the biblical remedy for sin in language that can be undersood is the over-all aim of the gospel commission. It is the ultimate objective of the Communication Department of the Seventhday Adventist Church.

As a means of underscoring the importance of this objective, a student at Andrews University, Daryl L. Meyers, is presently involved in a study of the place for and ministry of the local conference communication director and his work among pastors and laymen.

Here is where your help is needed. A questionnaire has been enclosed in order to give you the opportunity of expressing your thoughts and suggestions on this important subject. If you could take but a few minutes to fill out the form enclosed, you can be sure it will be a tremendous help to the researcher and of special interest to the church's Communication Department.

Sincerely,

\section{famed E. Chase}

James E. Chase, Director

Department of Communication

JEC $: k 1$ 
Andrews University Berrien Springs, Michigan 49104 (616) 471-7771

Apri1 21, 1980

Dear fellow worker:

Just recently you were selected among our Adventist workers in North America to receive a special questionaire dealing with the role of the local conference communication director in the work of the church. The response you make to this questionaire will be of great help in determining exactly what that role is and possible new directions the department might take in the near future.

If you could take just a few minutes to complete this survey and return it by April 30 in the envelope provided, it would be a tremendous help in seeing this project through to completion. Thank you in advance for honoring this request by your quick response.

May God bless you and each one of us as we continue to explore new and more efficient ways to communicate the gospel message.

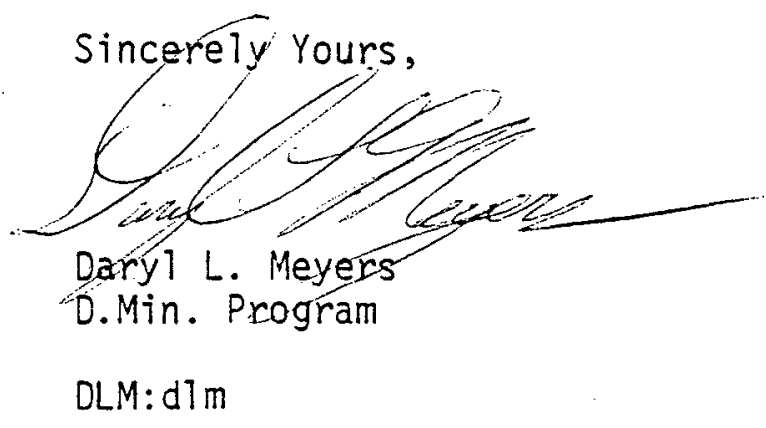


APPENDIX $H$

SURVEYS 


\section{IHE ROLE OF THE LOCAL CONFERENCE COMNUNICATION}

\section{DIRECTOR IN NORTH AMERICA}

$$
\text { (P-TPR-SMPR) }
$$

1. From the list below, please check those areas where you have recelved help during the past month from your conference communication director.

A. I have recelved assistance fron the conference cominication director in how to announce or publicize church activities by weans of the following medra:
18.
Radio
20.
Newspapers
22. other (spectfy)
19. IV
21. News Magazines

B. I have received assistance from the conference communication director with Internal coverage of local church activitles by means of:

23. Local Church Newsletters

24. Conference Church Papers

25. Unton Church Papers
26. The Adventist Review

27. other (specify)

C. I have recelved assistance from the conference communication director with church activities in the community such as:

28. Exhibits

29. Public Service Progranis

30. Parades
31. Service Clubs

32. other (specify)

D. I have received information, counsel or advice from the conference communfation director regarding the work of the:

33. Local Church Communication Secretary

36. Conference

34. Conference Department Directors

35. Conference Evangelist

37. President.

E. I have recelved assistance from the conference colmunication director by means of a workshop conducted in:

38. Joumalism 40. Radio-TV

42. Other (specify)

39. PR

41. Photography 
F. I have recelved help from the conference communtcation director through his promotion of:
43. Tithes offerings
44. Fund-ralsing Activities
45. The Appointment of Local Church PR Secretaries

The Appolntment of Institutional PR Directors

47. other (specify)

G. I have recelved the following resource materlals from the conference communication director:

48. News Releases

49. Audlo-visual Materials (Incl. Radio-TV Materials)

50. Advertisement Materiais
51. Brochures

52. other (specify)

H. My conference commulcation director has assisted me (1f you are an institutional PR director) in:

53. Institutional PR Planning Comittees

56. Preparing for

54. Joint Church-Institutional Programs

55. Preparing for Exhlbits

57.

1. I have recelved assistance from the conference cormunication director with my offlce work in:

58. Article or News Hriting

61. Preparation of PR Reports

59. Work on Photo Flles

62. other (specify)

60. Work on Biographical Files

J. I have recelved assistance from the conference commutcation director with photographic coverage of:

63. Local Church Activitles

65. Conference-wide Activities

64. Institutional Activitles

66. other (specify) 
K. The conference communication director has kept in personal contact with me by:

67. Phone

69. Bulletins

71. Other (specify)

68. Letter

70. Personal Visits

L. The conference comnunication director has helped me in solving PR problens:

72. In the Local Church

75. Conference-wide

13. In an Institution

76. Other/Does Not Apply

74. In the Conference office

II. Communication and Evangelism.

77. Specifically, what do you feel is the primary place of the local conference conmunication director in "fintshing" God's work?

The work of the conference conmunication director is:
A. Evangelism in temis of "seed-sowing."
B. Indirect evangelism in terms of "Image butlding."
c. Not evangel Ism in any sense.

III. In which of the following areas do you feel your conference communication director(s) would appreclate some professional or specialized training if it could be provided?

A. Practical training In:
78. Journalism
80. Layout \& Design
82. Other (speclfy)
79. Photography
81. Speech

B. Technical training in:
83. Advertising Methods
84. Fund-raising Methods
85. Cost Effect Iveness Studfes

86. Market Research

87. Other (specify) 
C. Spectal training in:

88. Radio Broadcasting

91. Korkshop or Seminar

89. TV Broadcasting

90. ___ Progran Analysis \& Design

0. ___ Progran Analysis \& Design

92. Planning \& Design other (speclfy)

D. Tratning in:

93. Counselling

94. Soul-winning Methods

95. Adventist Theology
96. Inter-personal Communication
Hethods

97. Other (specify)

E. Additional training in:

98. Demographlcs (population studles of given conmunities for the purpose of discovering and relating to felt needs of vartous communttles)

99. Principles of Management

100. The practical aspects galned through assoctating and interacting with SOA and non-SDA PR professionais

101. other (specify)

IY. The work of the conference conmunication director.

102. Which of the following statements most closely reflect your opinion of the relative importance of the work of the local conference communication director? (Please check ONAE space only)

A. Optlonal: A good department to have by could do without it on the local conference level.

B. Less fmportant than other departments of the conference, but essential.

C. Approximately equal In inportance to other conference

D. More Important than some departments, but less Important than others.

E. Ihe most Important department in the conference. 
v. General Information: (Please check the approprlate space.)
A. Age: 103. $20-29 \quad 105$. $40-49$
107. 60 plus 104. $30-39106$. $50-59$

B. Your Sex: 108. Male 109. Female

C. Denominatlonal Years of Service: 110. 1 - 5 yrs

113. $16-20$ yrs

111. $6-10$ yrs

114. 21 plus

112. $11-15$ yrs

D. What was your MAJOR field of study in college?

If your MAJOR was "communication" what was the area of empliasis?

115. Joumalism 117. Radio-TV 119. Other (specify)

116. PR

118. Speech

E. If your MIHOR was "communication" what was the area of enphasis?

120. Journalism 122. Radio-TV 124. other (specify)

121. PR

123. Speech

F. Since graduation. In what areas of comnunication have you recelved Job-related training?

125. Journal Ism

127. Radio-IV

129. other (specify)

126. PR

128. Speech

130. Please list brtefly the experlence you have had in those flelds related to public relations or communication.

IItle or Position

Years of Service

1.

2.

3.

4. 
131. How well do you know your conference communilcation director? (Please circle the letter Indicating your response.)

A. I don't know who he is.

8. I know who he is but I have never met him.

C. I have met him but I have recelved IIttle If any assistance from him.

D. I am well acqualnted with hfm.

E. Other (specify)

132. What would you IIke to have the conference cormunication director do for you, your church, or institution that would be of most inmedlate benefit?

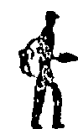

THANKS SO MUCH AGAINI WE ARE LOOKING FORHARO TO RECEIVING YOUR COMPLETEO SURVEY. 
1. What of fices do you currently hold in your conference? (Please check all that apply)
1.
7. Lay Activities
13. Education
2. Secretary
8. Sabbath School
14. Publishing
3. Treasurer
9. ___ Religious Liberty
15. Evangelist
4. Ministerial
10. Temperance
16. Communication
5. Youth
11. Health
6. ___ Stewardship
12. Trust Services
17. other

A. Which one of your offices do you feel you were called to direct primarily or to give special emphas is to?

B. In reality, which one of your offices is the most tine consuning?

C. Why?

11. From the following IIst. check only those activitles you have actually engaged in during the past month.

A. I have secured coverage of vartous church activities by means of:

18.

20. News papers

22. other

19. TV

21. News Magazines

B. I have given internal coverage to local church activities by means of:

23. Local Church Newsletters

26. 27.

24. Conference Church Paper

25. Union Church Paper The Adventist Review Other (speclfy) 
C. I have helped create church awareness through involvenient in the communtty by means of:

28.

29. Exhibits

30. Public Service Programs Parades
31. Service Clubs

32. other

D. I have given information, counsel, or advice to the:

33. Local Church Conmunication Secretary

34. Conference Department Directors

35. Conference Evangelist
36. Conference President

37. other (specify)

E. I have conducted a workshop in:

38. Journallsm

39. Public Relations

40. Radto-TV

F. I have promoted:

43. Tithes \& offerings

44. Fund-raising Activitles

45. The Appointment of Local Church Communication Secretartes
41. Photography

42. other (specify).

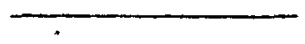

G. I have distributed the following resource materfals:

48. News Releases

49. Audio-visual Materlals (Inci. Radio-TV Matertals)

50. Advertisement Materials
51. Brochures

52. other (specify)
46.

The Appointment of Institutional PR Directors

47. Other (specify)

H. I have given assistance to Institutional PR directors through:

53. Involvement in Institutlonal PR Planning Coiniltees

54. Exhibft Preparations

55. Preparations for Parades
56. Joint Church Institut lonal Programs

57. Other (specify) 
I. I have done the following office work:

58. Article or News Writing

59. Work on Photo flles

60. Hork on Blographical Files
61. Preparation of PR Reports

62. other (spectfy)

J. I have provided photographic coverage of:
63. Local Church Activities
64. Institutional Activities

65. Conference-wide Activities

66. other (specify)

K. I have been In contact with local church leadershtp by means of:

67. Phone 69. Bulletins

71. other (specify)

68. Letter

70. Personal Visits

L. I have been involved In solving PR problems:

72.

73. of a Local Church of a Church Institution

74. in the Conference office
75. Conference-wide

76. Other (specify)

III. Communication and Evangel1sm.

77. Specifically, what do you feel is the primary place of the local conference comiunication director in "finlshing" God's work? (Check only OHE please)

The work of the conference comnulcation director is:
A. Evangelisin in terms of "seed-sowing."
B. Indirect evangelism in terms of "Inage bullding."
c. Not evangelism In any sense. 
IV. In which of the following areas of comminication do you feel you could benefit if you had the opportunity of receiving additional training?

A. Practical training In:

78. Journalism

80. Layout \& Design

82. other

79. Photography 81 . Speech

B. Technical training in:

83. Advertis ing Methods

86. Harket Research

84. Fund-ratsing Methods

87. other (specify)

B5. Cost Effectiveness Studies

C. Spectal training In:

88. Radio Broadcasting

91. Workshop or Seminar

89. TV Broadcasting

90.

90. ___ Program Analysis Design

92. Planning o Design Other (specify) (specify)

D. Training in:

93. Counseling

94. Soul-winning Me thods

95. Adventist Theology
96.

Inter-personal Communication Methods

97. other (specify)

E. Additional training In:

98. Demographics (population studies of given communit les for the purpose of discovering and relating to felt needs of varlous conmunities.)

99. Principles of Management

100. The practical aspects gained through assoclating and interactíng with SOA and non-SOA PR professionals

101. Other (spectfy) 
v. The work of the conference communication director.

102. Which of the following statements most closely reflect your op inion of the relative importance of the work of the local conference communication director? (Please check OME space only)

A. Optional: A good department to have but could do without it on the local conference level.

B. Less important than other departments of the conference,

c. but essential.

Approximately equal in importance to other conference departments.

D. More important than some departments; but less important than others.

E. The most important department in the conference.

VI. Gerieral Information: (Please check the appropriate space)
A. Age: 103. $20-29$.
105. $40-49$
107. 60 plus
104. $30-39$
106. $50-59$

8. Your Sex: 108. Male

109. Female

C. Denominational

Years of Service: 210. $1-5$ yrs

113. $16-20$ yrs

111. 6 - 10 yrs

114. 21 pius

112. 11 - 15 yrs

D. What was your MAJOR field of study in college?

If your MA.JOR was "comunication" what was the area of emphasis?

115. Journalism

117. Radio-TV

119. Other

110 . Public Relations

112. Speech 
E. If your MINOR was "communtcation" what was the area of emphasis?

120. Journalism

122. Radio-TV

124. Other (specify)

121. PR

123. Speech

F. Since graduation, in what areas of communfation have you recefved job-related training?

$-125$. Journalism

127. Radio-TV

129. Other (specify)

126. PR

128. Speech

C. Please list briefly the experience you have had in those fields related to public relations or comunication.

\section{Title or Position}

Years of Service

1.

2.

3.

H. During a typical 3 month period, what areas of communtcation do you fins yourself concentrating on the most frequently? (Writing. Radio-TV work. Photo coverage of church events. Involverent in solving PR problems. Involvement in fund-raising activities, Preparation of resource materials. Counseling, etc.)

I. What would you like administrators, pastors, or the church in general to do for you which would be of most immediate benefit to you and your dapartment?

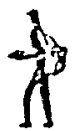

THANKS SO MUCH AGAINI WE ARE LOOKING FORHARO TO RECEIVING YOUR COMPLETED SURVEY. 
1. According to your knowledge, which of the following actlvities has your conference conmunication director(s) been engaged in during the past month? (Please check the appropriate spaces)

A. lle has secured coverage of varlous church activities by means of:

18.<smiles></smiles>

19. TV
20.

21. Newspapers News Magazines

22. Other (spectfy)

8. He gave internal coverage to local church activities by means of:

23. Local Church Newsletters

26. The Adventist Review

24. Conference Church Paper

27. Other (specify)

25. Union Church Paper

C. He helped create church awareness through involvement in the communtty by means of:

28. Exhibits

31. Service Clubs

29. Public Service Programs

32. Other (specify)

30. Parades

D. He has given information, counsel, or advice to the:

33. Local Church Comminication Secretary

36. Conference

34. Conference Departnent Directors

35. Conference Evangelist

37. President Conference Evangellst

E. He conducted a workshop in:

38. Journalism

39. PR

40. Radio-TV
41. Photography

42. Other (spectfy) 
F. He promoted:
43. Tithes \& Offerings
46. The Appointment of Institutional PR
44. Fund-ralsing Activities
45. The Appointment of Local Church Communication Secretarles

G. He has distributed the following resource materlals:

48. News Releases

49. Audlo-visual materials (Incl. Radio-TV Materials)

50. Advertisement Materials
51. Brochures

52. Other (specify)

H. He has assisted institutional PR directors by:

53. Involvement in Institutional PR Planning Committees

54. Helping with Exhibits

55. Helping with Parades

56. Assisting with Joint Church-Institutional Programs

57. Other (specify)

I. He has been involved in the following office work:

58. Article or News Hriting

61. Preparation of PR Reports

59. Work on Photo Files

62. other (speclfy)

60. Hork on Blographical Flles

J. He has provided photographic coverage of:

63. Local Church Activfttes

65. Conference-wide Activities

64. Institutional Activities

66. Other (specify) 
K. He has been in contact with local church leadershlp by:

67. Phone 69. Bulletins

71. other (spectfy)

68. Letter 70. Personal Vistts

L. He has been involved In solving PR problems:

72. In the Local Church

73. in the Institution

74. In the Conference office
75. Conference-wide

76. other (specify)

11. Communication and Evangellsm

77. Specifically, what do you feel is the primary place of the local conference communication director in "finislitng" God's work? (Check only one please)

The work of the conference conmunication director is:
A. Evangelisw in terms of "seed-sowing."
B. Indirect evangelism in terms of "Image bullding."
C. Not evangelism in any sense.

III. In which of the following areas do you feel your conference comunication director(s) might benefit by receiving additional training?

A. Practical tratning in:

78. Journalism 80. Layout \& DesIgn

82. other (specify)

79. Photography 81 . Speech

B. Technical training in:

83. Advertising Hethods

84. Fund-raising Hethods

85. Cost Effectlveness Studies
86. Market Research

87. other (specify) 
C. Spectal training in:

88. Radio Broadcasting

89. Television Broadcasting

90. Program Analysis \& Destgn

91. Workshop or Seminar Planning \& Destgn

92. other (specify)

o. Tralning in:

93. Counselling

94.

95. Soul-winning Methods Adventist Theology
96. Inter-personal Comminication Methods

97. Other (specify)

E. Additional training in:

$9 B$. Demographics (population studles of given communties for the purpose of discovering and relating to the felt needs of various commulttes.)

99. Principles of Management

100. The practical aspects gained through associating and interacting with SDA and non-SDA PR professionals.

101. Other (specify)

IV. The work of the conference communtcation director.

102. Which of the following statements most closely reflect your opinion of the relative importance of the work of the local conference communication director? (Please check ONE space only)

A. Optional: A good department to have but could do without It on the local conference level.

8. Less Important than other departments of the conference. but essential.

c. Approximately equal in importance to other conference departments.

D. More important than some departments, but less Important than others.

E. The most Important department in the conference 
v. General Information:

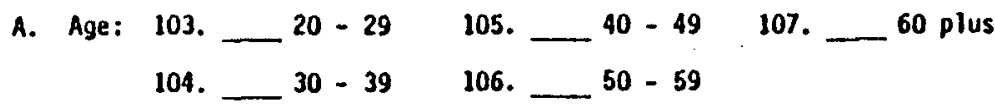

8. Your Sex: 108. Male 109. Female

c. Denominational

Years of Service: 110 1 - 5 yrs

113. $16-20$ yrs

111. 6 - 10 yrs

114. 21 plus

112. $11-15$ yrs

D. What was your MAJOR field of study in college?

If your MAJOR was "communication" what was the area of emphasis?

115. Journalism

117. Radio-TV

119. Other (specify)

116. PR

118. Speech

E. If your MIIIOR was "communication" what was the area of emphasis?

120. Journalism 122. Radio-TV 124. Other (specify)

121. PR

123. Speech

F. Since graduation, in what areas of connunication have you recelved Job-retated tralning?

125. Joumailsm 127. Radio-TV

128. Other (specify)

126. PR

128. Speech

6. Please 11st briefly the experlence you have had in those fleids related to public relations or conmunication.

\section{Ittle or Position}

\section{Years of Service}

1.

2. 
H. What do you need right now that your conference communication director(s) could provide help with?

THANKS SO MUCH AGAINI WE ARE LOOKING FORWARO TO RECEIVING YOUR COMPLETED SURVEY.

$\stackrel{\sim}{*}$

$\omega$ 
APPENDIX I

ADDITIONAL OFFICES OR POSITIONS HELD BY CONFERENCE

COMMUNICATION DIRECTORS OTHER THAN THOSE LISTED

IN THE SURVEY 
ADDITIONAL OFFICES OR POSITIONS HELD BY CONFERENCE COMMUNICATION DIRECTORS OTHER THAN THOSE LISTED IN THE SURVEY

I. Conference Offices Held:

1. A.S.I.............. 4

2. Spirit of Prophecy emphasis ........ . 2

3. Community service ........... 1

4. Medical recruitment ........... 1

5. District pastor ........... 1

6. N.S.O............... 1

7. Union paper correspondent ........ 1

II. Office Called to Direct Primarily or to Give Special Emphasis to:

1. Association secretary .......... 1

2. Gleaner correspondent ......... 1

III. Office Considered the Most Time Consuming:

1. Conference executive committee ........ 1

2. Housing coordinator .......... 1

3. New to responsibility - can't predict.... 1 


\section{APPENDIX $J$}

ADDITIONAL ACTIVITIES ENGAGED IN OR ASSISTANCE GIVEN

BY THE CONFERENCE COMMUNICATION DIRECTOR DURING A

ONE MONTH PERIOD (NOT LISTED IN THE SURVEY) AS

PERCEIVED BY THE RESPONDENTS 
Additional activities engaged in or assistance given by the conference communication director during a one month period (not listed in the survey) as perceived by the following respondents.

I. Pastors:

1. Bulletins, news releases and newsletters sent by mail.

2. Work with church papers

3. Photography of special events

4. Contact maintained and assistance given by letter

5. Activities or materials centering around health programs

6. Involvement with workshops 7

7. Workshops held but not attended by pastors 7

8. Program assistance (music, school, etc.) 6

9. News article writing 4

10. Stewardship assistance. 3

11. Little or no help received 2

12. Handbill preparation and assistance 2

13. Fair booths or exhibits 3

14. PR assistance with evangelist meetings 2

15. Ingathering assistance 2

16. Local contact maintained through general communications at union or conference office. 2

17. Local contact maintained through ministerial meetings

18. Local contact maintained through workers' meetings

19. Local contact maintained through camp meetings 1

20. Local contact maintained through various other meetings

21. Promotion of major church events

22. Assistance with regular communication reports. I

23. Assistance with pastoral profiles I

24. Too much junk mail received I

25. Resource materials on religious liberty 1

26. How to conduct interviews 1

27. Mass mailing technics 1 
28. IIW logs

29. Work with highway signs

30. No help received for metro area

31. Work with film

32. No response--absent for medical reasons

33. Assistance given local church communication secretary

34. Assistance given with regards to brail foundation

35. Workshop centering on work of clerk

36. Promotion of lay activities reports

37. Bible doctrinal resource materials

38. Role description of conference communication director

39. Obituary guidance

40. $P R$ assistance given through sermons

41. Contact maintained through seminars

42. Various monthly contacts

43. No personal contact in three years

44. Very little contact

45. Contact through public announcements at meetings

46. Contact via church visits

47. Never has contacted me personally 1

48. He is my neighbor i

49. Mission coverage assistance given 1

50. Assistance given in writing newspaper articles

51. Assistance was given when help was requested 1

52. No help requested

II. Conference Communication Directors:

1. Work with church papers

2. Bulletins, news releases and newsletters sent by mail

3. Information, counsel, or advice given pastors or other local leaders

4. Multi-media involvement 
5. Exhibits or displays 2

6. Health-orientầ tèd programs 2

7. Assistance given local church secretaries 2

8. Information, counsel, or advice given school administrators

9. Workshop conducted in communication or PR 2

10. Workshops (general) 2

11. Contact with local church leadership via workshops

12. Information, counsel, or advice given budget committee

13. Contact with local newspapers

14. Bible conference involvement

15. Work with Dorcas

16. Work with bali teams

17. Information, counsel, or advice given Institute on Health

18. Workshop on camp meeting promotion

19. Workshop on union paper subscription procedures

20. Press secretary workshops

21. Promotion of carolina canter $?$

22. St. of Life promotion 1

23. Have distributed ideas. 1

24. Have sent out monthly assignments 1

25. Have distributed communication workbooks 1

26. Assisted institutional PR directors with brochures

27. Assisted institutional PR directors with fund-raising

28. Designed brochures

29. Multi-media productions photography 1

30. School photography 1

31. Have helped solve problems at a health
condition center

32. New to responsibility 1

33. Have helped solve PR problems involving a conference defamation case

34. Have conducted seminars 
III. Conference Presidents:

1. Work with church papers 6

2. Multi-media involvement 2

3. Covered church activities via bulletins 2

4. Community awareness created through welfare ministry

5. Promoted evangelism 2

6. Camp meeting promotion 2

7. Community awareness created through an airport display

8. Has given information, counsel, or advice to pastors

9. Conducted a workshop on "Tidings" information 1

10. Conducted a PR seminar 1

11. Conducted a workshop at camp meeting 1

12. Promoted local conference items (general) I

13. Promoted family finance 1

14. Has assisted institutional PR directors

15. Has helped with camp meetings planning 1

16. Has promoted good office morale 1

17. Has assisted with youth work 1

18. Has provided photographic coverage at camp :

19. Photographic coverage of community service
center help given to tornado victims

20. Covered church activities via constituency
reports

21. Distributed "Te11" magazine 1

22. Miscellaneous 1 


\section{APPENDIX K}

PROFESSIONAL OR SPECIALIZED TRAINING NEEDED BY CONFERENCE

COMMUNICATION DIRECTORS AS SUGGESTED BY THE

ADDITIONAL COMMENTS OF THE RESPONDENTS 
Professional or specialized training needed by conference communication directors as suggested by the additional comments of the following respondents.

I. Pastors:

1. Don't really know

2. Doesn't need any

3. Work with radio and TV

4. Skills acquired for meeting local church needs

5. $P R$

6. Training in PR for holding evangelistic meetings

7. Training in inter-personal relationships 3

8. Needs help in all areas 3

9. Training in communication 3

10. Developing radio and TV spots 3

11. He needs help in a number of areas, although, it's doubtful he would appreciate it

12. Saturation media presentations in large metro areas

13. Video tape and film training 2

14. Seminar training 2

15. Availability 2

16. How to localize world (church) news 2

17. More time for communication work 2

18. No opinion 1

19. Multimedia programming 1

20. How to make a strong impact. 1

21. Direct mail technics 1

22. Training in evangelism 1

23. Christian education 1

24. He is very happy with his study and work

25. Practical PR methods 1

26. Working with media professionals 1 
27. Writing 1

28. Fund-raising methods 1

29. Internal promotion (conference) 1

30. Professional way of resigning 1

31. How to involve everyone in his program 1

32. Washing pots--he bakes bread 1

II. Conference Communication Directors:

1. More opportunities for professional growth 2

2. Handling PR problems 1

3. Designing an effective PR program i

4. Motivation 1

III. Conference Presidents:

1. TV production 1

2. He would receive benefit from any of the training mentioned

3. External media training

4. No training needed 
APPENDIX L

ADDITIONAL REMARKS BY THE RESPONDENTS REGARDING THEIR

MAJOR FIELD OF STUDY IN COLLEGE 


\section{ADDITIONAL REMARKS BY RESPONDENTS REGARDING MAJOR FIELD OF STUDY IN COLLEGE}

I. Pastors:

1. Did not attend college 3

2. Retail merchandizing 1

3. Ph.D. in speech 1

4. Industrial administration 1

5. Ph.D. in sociology 1

6. Dentistry 1

7. Public health 1

8. $P R \quad 1$

9. Journalism 1

II. Conference Communication Directors:

1. Psychology 1

III. Conference Presidents:

1. No remarks for this section 0 


\section{APPENDIX M}

ADDITIONAL REMARKS OF RESPONDENTS REGARDING COLLEGE MAJOR OR MINOR IN COMMUNICATION:

AREAS OF EMPHASIS 


\section{ADDITIONAL REMARKS OF RESPONDENTS REGARDING \\ COLLEGE MAJOR IN COMMUNICATION: \\ AREAS OF EMPHASIS}

I. Pastors:

1. Greek

2. Ph.D. in speech 1

3. Journalism and speech 1

II. Conference Communication Directors:

1. No remarks for this section 0

III. Conference Presidents:

1. No remarks for this section 0

COLLEGE MINOR IN COMMUNICATION:

AREAS OF EMPHASIS

I. Pastors:

1. Education 1

2. Speech therapy 1

3. Telecommunications 1

4. History 2 2

5. Industrial arts 1

II. Conference Communication Directors:

1. Secondary education 1

III. Conference Presidents:

1. Economics 1 


\section{APPENDIX $N$}

POST-GRADUATE JOB-RELATED TRAINING IN COMMUNICATION:

ADDITIONAL AREAS 
I. Pastors:

1. Photography 4

2. Church growth studies 3

3. Practical experience 2

4. Salesmanship 2

5. Learning from materials sent from the

6. English research 1

7. Inter-personal communication skills 1

8. Bulk mailing technics 1

9. Time management 1

10. Video tape 1

11. Evangelistic advertising 1

12. Public health ?

13. Conference communication director 1

14. Leading out in workshops 1

15. Teaching in journalism 1

16. PR work 1

II. Conference Communication Directors:

1. Photography 6

2. Ministerial work 3

3. Development 1

4. Writing 1

5. Surveys 1

6. Multi-media production 1

7. Layout and design 1

8. Communication skills 1

III. Conference Presidents:

1. Management 1 


\section{APPENDIX 0}

ADDITIONAL REMARKS REGARDING THE DEGREE OF ACQUAINTANCE PASTORS HAVE WITH THE LOCAL CONFERENCE COMMUNICATION DIRECTOR 
ADDITIONAL REMARKS REGARDING THE DEGREE OF ACQUAINTANCE PASTORS HAVE WITH THE LOCAL CONFERENCE COMMUNICATION DIRECTOR

1. I am well acquainted with him but have received little assistance from him 9

2. He just arrived in our conference 7

3. I have met him and have received some assistance from him

4. I appreciate his assistance 4

5. We don't have a conference communication director 3

6. I really don't need his help 3

7. He can't speak my language 2

8. We need a change 2

9. He has little time to give assistance for he has more than one department 2

10. I don't know him very well 2

11. I am acquainted with him 2

12. I just arrived in the conference. 1

13. I receive some assistance but onty when I ask 1

14. I work with him on projects 1

15. I work with him on projects 1

16. I'm not sure that we have one 1

17. He hasn't been in our area for six months 1

18. I know him fairly well but not as a PR man $T$ 


\section{APPENDIX $P$}

ADDITIONAL REMARKS REGARDING AREAS OF COMMUNICATION CONCENTRATED ON THE MOST FREQUENTLY BY CONFERENCE COMMUNICATION DIRECTORS DURING A TYPICAL THREE-MONTH PERIOD 


\section{ADDITIONAL REMARKS REGARDING AREAS OF COMMUNICATION CONCENTRATED ON THE MOST FREQUENTLY BY CONFERENCE COMMUNICATION DIRECTORS DURING A TYPICAL THREE \\ MONTH PERIOD}

1. News coverage for camp meetings 1

2. Leading out in workshops 
APPENDIX Q

ADDITIONAL REMARKS REGARDING THE ASSISTANCE CONFERENCE PRESIDENTS AND. PASTORS NEED FROM THEIR CONFERENCE COMMUNICATION DIRECTORS 
ADDITIONAL REMARKS REGARDING WHAT CONFERENCE PRESIDENTS NEED RIGHT NOW THAT THEIR CONFERENCE COMMUNICATION DIRECTORS COULD PROVIDE HELP WITH.

1. Need more funds.

2. Much!

3. Need help with general duties. 
Additional remarks regarding what pastors would like to have their conference communication directors do for them, their churches or institutions that would be of most immediate benefit.

1. Impress the church with the importance of communication and the favorable impact it could have on the nonAdventist community.

2. Give the gospel message to the unsaved.

3. Get out and give some evangel istic campaigns.

4. Help promote Christian stewardship.

5. Accept more of the responsibility of his office.

6 . Coordinate al1 conference programs.

7. Design an overall communications strategy for the conference.

8. Emphasis on balanced use of the electronic media and journalism.

9. Do a layout for Reader's Digest like the Mormans did.

10. More research into humble Christlike methods of evangel ism.

11. Stop sending questionnaires.'

12. Fear expressed regarding negative conclusion to survey.

13. Need a more coordinated Christ-centerd thrust in communication.

14. Need to be more strongly motivated.

15. Need more news about SDAs in various periodicals.

16. Need a conference-wide, message-orientated advertising campaign.

17. Need funds made available so pastors can belong to business and civic clubs.

18. Need a:more united effort among our churches in mass media evangel ism.

19. Need more planning from the local level rather than from the top.

20. Need more funds so the communication director can do his work.

21. Need for the communication director to do more than just pass on materials on to us.

22. Need him to do the work of the communication director. 
23. Need him to accept a call elsewhere so we can get a new man.

24. Need him to assist, but that is all.

25. Need help in pastoral work, not criticism.

26. Need him to help evaluate local church effectiveness in the community.

27. Need more external church PR.

28. Have no special suggestion for he is new in the communication dept.

29. Need more district-wide workshops, rather than "area-wide."

30. Need dynamic world-wide PR from the General Conference level.

31. Need help with radio work in New York City.

32. Need him to help us keep ahead on church calendar of events. 


\section{APPENDIX R}

LETTER AND LIST OF DENOMINATIONS FROM THE GENERAL CONFERENCE COMMUNICATION DEPARTMENT

SAMPLE LETTER SENT TO NON-SDA DENOMINATIONS

CORRESPONDENCE FROM VARIOUS DENOMINATIONS 
September 5, 1980

General Conference of

\section{Seventh-day Adventists}

CHURCH WORLD HEADQUARTERS: 6840 EASTERN AVENUE NW, WASHINGTON, DC 20012 USA TELEPHONE: $(2021723.0800$ - CABLE: ADVENTIST, WASHINGTON * TELEX: 89.580

Dary 1 Meyers

Maplewood Apartments, C-69

Berrien Springs, MI 49103

Dear Dary1:

I promised to send to you some addresses of major church organizations, and I trust these will be some help to you in your research. Certainly there are other church organizations with fine communications programs, but I have included those which I feel have value for your research.

We're pleased to help you. Let's keep in touch.

Sincerely,

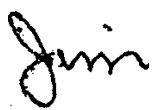

James E. Chase, Director

Department of Communication

$J E C: k 1$

Enclosure 
MAJOR CHURCH ORGANIZATIONS

Southern Baptist Convention

460 James Robertson Parkway

Nashville, TN 37219

United Methodist Communications

601 West Riverview Avenue

Dayton, $\mathrm{OH} \quad 45406$

The Church of Jesus Christ

of Latter-Day Saints

50 East North Temple Street

Salt Lake City, UT 84150

United States Catholic Conference

1312 Massachusetts Avenue, N.W.

Washington, D.C. 20005

Lutheran Church in America

Office for Communications

231 Madison Avenue

New York, NY 10016

The Lutheran Church--Missouri Synod

500 North Broadway

St. Louis, MO 63102

The United Presbyterian Church in the USA

475 Riverside Drive

New York, NY 10027

The Episcopal Church

815 Second Avenue

New York, NY 10017

Church of God

Mass Communications Board

Box 2299

Anderson, IN 46011

United Church of Christ

105 Madison Avenue

New York, NY 10016
CONTACT PERSON

W. C. Fields, Director of

Public Relations

Curtis A. Chambers, General Secretary Nelson Price, Director, Public Media Division

Bishop Joseph R. Crowley, Chairperson Communication

William B. Cedfeldt, Executive Director

Mr. Victor Bryant, Executive Secretary

Board for Public Relations

Rev. Frank H. Heinze, Managing Director, Communications Division

John C. Goodbody, Executive for Communication

Maurice Berquist., Director

Rev. Everett C. Parker, Director, office of Communication

Information obtained from Yearbook of American and Canadian

Churches 1980, edited by Constant H. Jacquet, Jr., published by

Abingdon Press: Nashville, TN. 
Andrews University Berrien Springs, Michigan 49104 (616) 471-7771

September 22, 1980

Rev. Everett C. Parker, Director

Office of Communication

United Church of Christ

105 Madison Avenue

New York, NY 10016

Dear Rev. Parker:

The Seventh-day Adventist Church, with its world-wide network of churches, medical facilities, and educational institutions, is highly interested in acquiring a better understanding of modern communication methods in order to proclaim more effectively and efficiently the "good news" of the gospel story.

To assist us with our research along this line, we would be extremely grateful for whatever insights and materials you could send us relative to your own church's use of modern communication methods in its ministry. Some of the areas we would appreciate receiving your help in are as follows:

1. How does your church view public relations or communication? (radio, TV, writing, advertising, photography, community relations, etc). Is it seen as "seed-sowing" evangelism (breaking up the ground in preparation for the harvest); indirect evangelism in terms of church "image building"; or is it viewed in some other way? What place does communication have in your church? How important is it as compared to other departments of your church?

2. What type of training or background do your PR or communication leaders (local and national) have in the field of communication?

3. How do you go about (localiy and nationally) making the community aware of your church's activities, goals, services, etc?

4. What kind of publicity do you give to local and national church events?

5. How do you view the importance of your church's relationship (local and national) to community leadership (political, business, and social leaders, etc)? How do you go about establishing and maintaining this relationship? 
6. Are your communication or PR leaders seen mainly as resource men or are they viewed in some other way?

7. Do they hold other church positions in addition to their involvement in PR or communication? If they do care for more than one office, what affect does this have on their success in the communication area?

8. As you look ahead, what part do you see public relations or communication playing in the work and development of your church?

Thank you so much in advance for your help with our research in this area. We also want to thank you for doing your best to send us your response by October 10.

May God bless you in your ministry is our prayer.

Sincerely yours,

Dary] L. Meyers

D. Min. Program 
SOUTHERN BAPTIST CONVENTION 460 JAMES ROBERTSON PARKWAY, NASHVILLE, TENNESSEE 37219 (615) 244-2355

Wilmer C. Fields, Assistant to the Executive Secretary and Director of Public Relations

September 26,1980

Mr. Daryl L. Meyers

Andrews University

Berrien Springs, Michigan 49104

Dear Mr. Meyers:

Unfortunately an extremely busy schedule does not permit me the time to give extensive answers to all the questions you have outlined. Perhaps the following summary may be of some assistance to you.

There are approximately 350 public relations professionals working in Southern Baptist Convention agencies, organizations and institutions. In addition the SBC Radio and Television Commission functions as a separate agency and will receive from the Cooperative Program (our major channel of denominational finance) $\$ 3.4$ million during the 1980-81 fiscal year.

All of this says that the denomination places a priority on public relations and communications. The objectives for all this work range widely but do include evangelism and missions both directly and indirectly.

As you would expect, the professionals working in this area come with a diversity of training and experience to their present positions. More and more these days however we are seeing young men and women who have degrees in their professions and also at least some seminary training.

At every level, national, state, county and local, these professionals use a wide variety of approaches to good relationships with their neighbors.

Internal communications within the denomination of 13.4 million members are maintained in a multiplicity of ways. Chief among them would be the 34 Baptist state papers which now have a combined circulation of 1.8 million, most of them weekly journals . There are national magazines targeted for certain audiences within the denomination. Baptist Press, the newsservice of the Southern Baptist Convention is used both for internal and external news handling. 
Mr. Daryl L. Meyers

September 26, 1980

Page 2

These public relations and communications professionals

range all the way from recently graduated college students to seasoned veterans, and their influence within their organizations likewise varies. Some of them have additional portfolios. Naturally the additional duties restrict the time and effectiveness of their success in communications.

The need of religious bodies for communications and public relations skills will increase as the years move along. The mounting competition for the attention, interest and loyalties of people demand more sophistication and more effectiveness to get a religious message heard considered accepted and put into action.

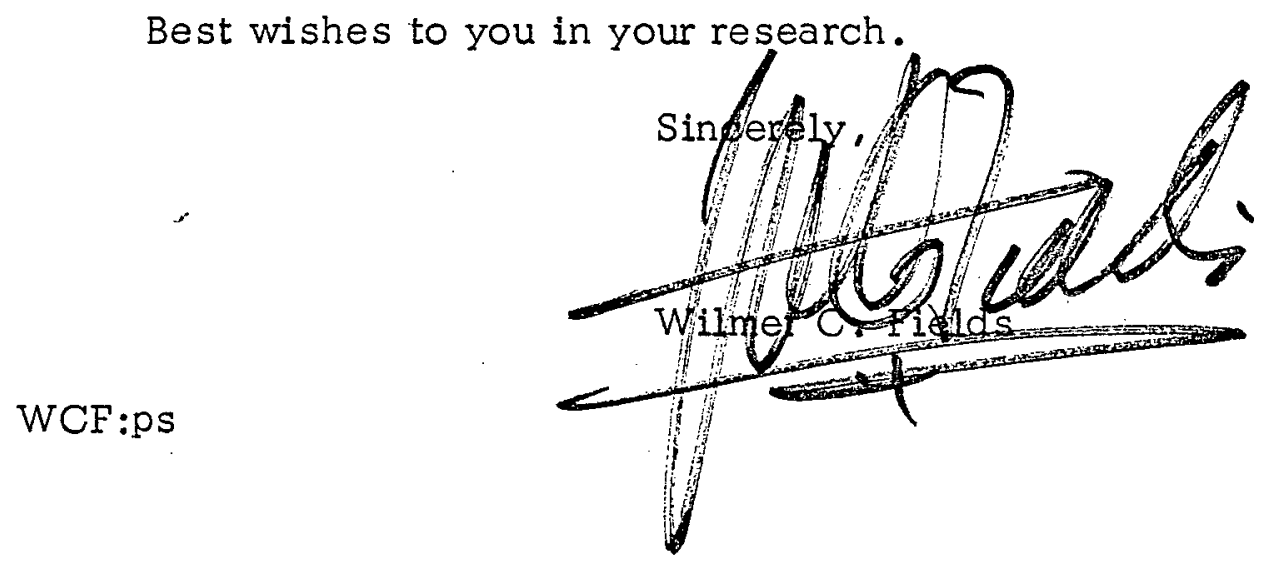




\section{The Lutheran Church - Missouri Synod}

DEPARTMENT OF PUBLIC RELATIONS

500 NORTH BROADWAY • SAINT LOUIS, MISSOURI 63102

VICTOR W. BRYANT

Director

October 2, 1980

TELEPHONE

$314-231-6969$

Mr. Dary1 L. Meyers

Andrews University

Berrien Springs, Michigan 49104

Dear Mr. Meyers:

Mr. Bryant will be out of town for the week but has asked me to respond to your inquiry of September 22nd. I will respond using your numbers as the focus of the information:

1. Both "preparation for the harvest" and "image building" are seen as communications needs. Strategies for each differ but always the identity of the local congregation needs to be the focus if those who receive the communication are to know where the convictions stated can be investigated further in a face-to-face situation. Please see the attached by-laws. The Division of Communications in the LCMS is comprised of several boards responsible for various methods of communication (print, electronic media, films, etc.) and their internal or external applications.

An insert in the enclosed "Good Things Happen When..." will show relative importance in terms of financial commitment.

2./5. Synod headquarters personnel hold degrees in communications and job experience outside the church. The 38 District personnel. (an editor and a PR Director for each unit) serve as volunteers, and attend a three-day workshop each biennium. Their boards are composed of laity active in communications.

3./4. External awareness is sought for in the 30-year-old "This Is The Life" award-winning dramatic television series, the 50-year-old "The Lutheran Hour" preaching series, several devotional radio series, 
Page Two

Mr. Daryl L. Meyers

October 2, 1980

once-a-year exposure on the several network religious series, occasional regionally-placed Preaching Through The Press advertising in. Sunday supplements, national religious radio networks (such as Ecumedia), and local radio and tv guest placement.

4. Example: Congregational Advertising Packet \#I.

6. Both resource (trainers, consultants) and working communicators interacting with media where they are located.

7. Yes, and this volunteer part-time service does diminish District communications effectiveness.

8. Communications is not a part of the Great Commission of our Lord. The Churchis a living vibrant communication to the world as Christ Jesus' body at work until His return. Each member is His light set upon a hill and that is the reason members remain earth-bound for the moment.

Our Savior blesses you, Daryl, that by looking at you others might rejoice and give, thanks unto The Father. Whistle if I can lend a hand.

In His Service,

JR: ht

Enclosures

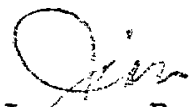

Rev. Jamés Rassbach Assistant Director 


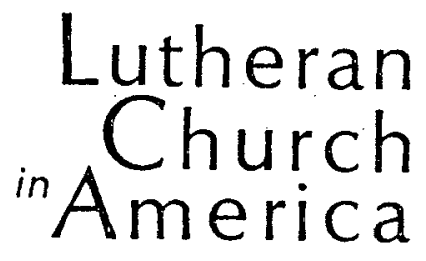

277

231 MADISON AVENUE NEW YORK, N.Y. 10016

Cable: Lutheran

212-481-9642

Office for Communications

October 6,1980

Mr. Daryl L. Meyers

D. Min. Program

Andrews University

Berrien Springs, Michigan 49104

Dear Mr. Meyers:

Your letter requesting information regarding the role of modern communication methods in the Lutheran Church in America has been forwarded to me for reply inasmuch as Mr. Cedfeldt is currently out of the office and your letter requested a reply by October 10. I hope the following is what you are interested in and that, if you require further information or elaboration, you will not hesitate to contact us. We will do what we can to respond and cooperate with you in your research project.

1. How does your church view public relations or communication?

The LCA separates public relations from communications. Public relations, we view as providing news about the LCA and its activities, programs, personalities, and general public image. Comunication, we view as that interaction which conveys information necessary for accomplishing our mission as a responsive church. Therefore, to us, communication is far more complex and vitally important than is public relations. Communications affect our total activity, internal and external. Public relations, while important in its own right, is related to our external activities. Communications and public relations would relate to evangelism as a pre-evangelistic, or, as you state: "seed sowing," evangelism. The activities relating to public relations and comunications are considered to be very important to our church and its work to the degree that:

a. we have a constitutionally mandated national office;

b. each of our synodical judicatories have constitutionally mandated offices;

c. We encourage each congregation to have a committee, and

d. most of the churchwide agencies have a staff person with ful1-time responsibilities related to communicating the work of that unit. 
2. What type of training do our PR/communications persons have?

Each of the persons who have these responsibilities in the church has a background in the communications field: editing, broadcasting, newspaper reporting, journalism education, and is given encouragement to continue activity in the field through personal reading, involvement in conventions and professional organizations, occasional attendarice at seminars, and in formal study.

The fall before each biennial convention our office conducts a workshop in the convention city to develop working relationships between the ICA's synod PRT chairpersons, editors, churchwide agency communicators and the office for communications staff; to improve communicating skills; to extend horizons and to stimulate creativity among those who would engage in helping the LCA reach out with communications.

3. How do we go about making the community aware?

We publish a magazine, THE LUTHERAN, with a subscription listing of 590,431. We provide news releases, information about various officials, schedule new conferences, and maintain a close working relationship with religion editors and interested individuals. We encourage local congregations and.synodical committees to do the same. When we have a major campaign, we work through and with these comittees at both levels and find that that process works well.

4. Publicity -- we provide for local and national church events. We schedule news conferences for reporters and editors for all media, television, radio and newspapers. We provide personalities for appearances and interviews and provide news releases on all significant events. We provide training workshops and a kit for local congregations to use in relating to local mass media.

5. Importance of church relationship to community leadership?

We view this as very important and encourage local congregational involvement in community affairs. We maintain relationships on the national level through this office, internationally through several intemational organizations of which we are corporate members and of which several of our staff have individual professional memberships. We urge local participation and involvement as well.

6. Are leaders seen as resource persons or some other way?

The communications persons are seen as resource persons in that they serve committees and workshops as leaders. However, they also are professionals that function as producers, and coordinators in their specialities.

7. Do they hold other positions?

No, the staff is full time and workload is such that it would prohibit their having additional responsibilities. 
Mr. Dary 1 L. Meyers

October 6, 1980

Page 3

8. Looking to the future?

The future of communications and public relations in the LCA includes much more stress on new forms of communications as we utilize cable, video format, satellites and yet to be revealed technology.

I hope that this information is helpful to you in your research.

Yours "truly,

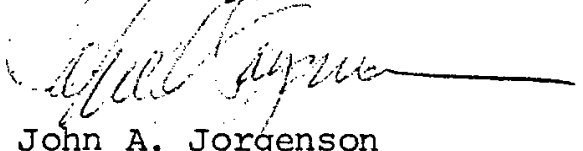

John A. Jorgenson

Assistant Director

Department of Press, Radio and Television

$J A_{N} \mathrm{~J}: \mathrm{b}$ 
October 6, 1980

\section{inited}

\section{netrinclist} communicetions

75 Piverside Drive, Suite $1370^{\circ}$ lew York, New York 10027

$12 / 663-8900$

Jelson Price

lirector

'ublic Media Division

JEW YORK VASHINGTON

IASHVILLE IAYTON

:VANSTON
Daryl L. Meyers

Andrews University

Berrien Springs, Michigan 49104

Dear Mr. Meyers:

Your letter requesting information regarding the communications program of the United Methodist Church has forthright questions with extremely complex answers.

The United Methodist Church has established a general commission on communications known as United Methodist Communications. I'm enclosing several documents which will be directly responsive to a number of your questions :

1. The legislation in our 'Discipline" which sets up the general commission on communication

2. The action by our 1980 General Conference on a television presence and ministry and authorization to embark in early 1981 on a $\$ 25$ million capital funds campaign.

3. A resolution on a church on a mass media culture adopted by our 1980 General Conference.

4. A staff and board paper on public relations in the United Methodist Church.

5. A staff paper on news and news service in the United Methodist Church.

6. News releases on the appointment of our new national public relations director.

7. A comprehensive communications plans adopted by the 1980 General Conference.

United Methodist Communications has three major divisions benevolence, promotion and interpretation, which works at interpretation of the denominations program and benevolence funds to its constituency; production and distribution, which produces audiovisual resources for the denomination and its national agencies; 
and the public media division, which includes United Methodist News Service and program staff charged with developing radio, television and cable programming for the denomination. We have a staff of approximately 115 persons located in five cities, New York, Nashville, Dayton, Evanston and Washington, D.C. In addition we have field staff in San Francisco, Little Rock and Atlanta. We have a communication education defartment which undertakes training events in such things as local church newsletters, women in media, production skills, and broadcast programming. We operate InfoServe, a telephone information service which can be called by any pastor, leader or member to request information about The United Methodist Church. Calls are toll free.

Our staff are professionally trained in the areas of their job descriptions.

In addition many conferences and areas have communications staff persons. Sometimes these persons carry other portfolio, but at a national level this would not be the case. Our United Methodist News Service covers national events and news of the denomination and disseminates to area and conference publications, daily newspapers, minority press where appropriate and religious press. They issue from 550 to 600 news releases and features per year.

Our news service is seen primarily as just that, a eompetent forthright, balanced service. Our sfecial services unit takes initiative in placing articles and interesting media people in events and issues. Our public relations office will also take an aggressive stance in this respect.

We see communication as an integral part of the ministry of any denomination, local church or religious organization. We believe it is appropriate in communicating to educate, to witness, to evangalize, to give information, and to motivate. In each major communications project we try to identify the primary purpose. We recognize the times that it is necessary to have as a purpose the interpretation andministry of the denomination but especially in programming our purpose moves towards serving the needs of specific audiences: Communications will take on a larger role in our denomination I think as we move in to our $\$ 25$ million funds campaign in 1981 and as we begin to build a base of media companies providing on-going income for the communication ministry of the denomination.

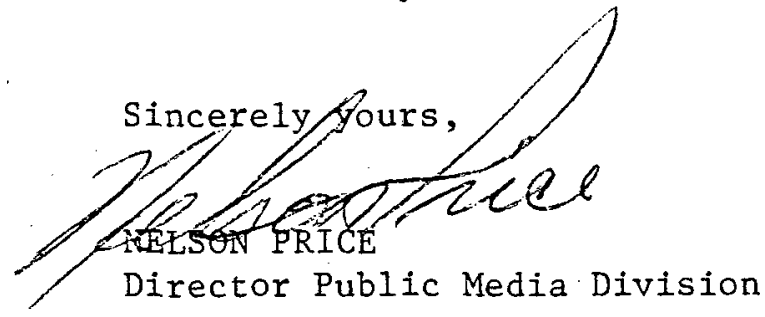

$\mathrm{NP} / \mathrm{vd}$

encl. 
Office of Promotion and Training

October 10,1980

Dary l L. Meyers

Andrews University

Berrien Springs, Michigan 49104

Dear Mr. Meyers:

Thank you for your letter of September 22 to Bishop Crowley regarding the use of modern communications methods proclaiming the "good news" in Christ. I have to commend you for your incisive questions.

Unfortunately the only answer that I can give is that these questions are far from resolved in the Catholic Church. There are many differing points of view. The newly-founded Catholic Communication Campaign, a national program to raise funds to support media at the service of the gospel, may prove to be a catalyst in resolving these key questions. I expect that over the next year or two, the committee responsible for undertaking this Campaign will be forced to make practical decisions that cannot ignore the issues.

As a matter of fact, I would like to ask you the favor of sharing the results of your research with us. Perhaps it can facilitate our own process.

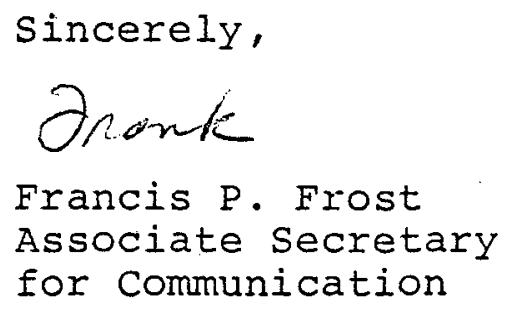

FPF : jbd 
1303 East Fifth Street, Anderson, Indiana 46011 317/642-0256

October 14,1980

Mr. Daryl L. Meyers

Andrews University

Berrien Springs, MI 49104

Dear Mr. Meyers:

I am happy to cooperate with your program in determining what policy should be instituted in the Seventh-day Adventist Church with reference to communication. In answer to your questions:

1) There is no well-defined philosophy of communication within the Church of God, although the expansion of our Radio and Television Board into a Communications Board is an evidence of awareness. It is the intention of this Board to facilitate and to initiate communicative procedures for all the other Agencies of the Church.

2) At the present time, communication training is limited to occasional seminars and training programs for ministers and lay leaders.

3) Each Agency of the Church has a program of information which is fed to sources such as the media, nationally and locally. We try to do some training in this, although I would have to say the program is inadequate.

4) For major church events, information is relayed to national news agencies, and for area events it is relayed by the sponsoring group to local news media.

5) It is obvious that the relationship of the church programs in the community is of tremendous importance. The philosophy of the Church as a whole is that the Church is a leavening agent in the community and affects, as such, all phases of life. 
Mr. Daryl Meyers

October 14, 1980

Page 2

6) Our communication leaders are seen both as resource people and facilitators.

7) We have one office that has a staff of about eleven persons. Out of this office proceeds our radio and television ministry.

8) Looking toward the future, I see communication as being a major thrust of the total Church. Skills in this department will be developed in cooperation with our colleges and already established training activities.

I hope this information is of help to you. I will be interested in finding out what you learn in your survey.

Sincerely,

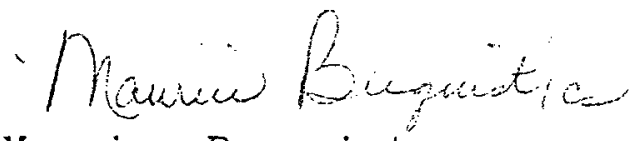

Maurice Berquist

Executive Secretary-Treasurer

$\mathrm{MB} / \mathrm{cs}$ 

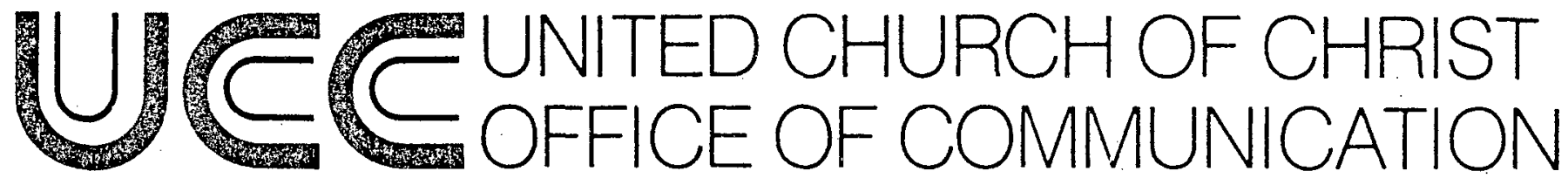

105 MADISON AVENUE, NEW YORK, N.Y. 10016 (212) 683-5656 NIGHT 683-5740

REV. C. SHELBY ROOKS, Chairman REV. EVERETT C. PARKER, Director REV. EUGENE A. SCHNEIDER, Associate Director

October 3,1980

Mr. Darry1 L Meyers

Andrews University

Berrien Springs, MI 49104

Dear Mr. Meyers:

The United Church of Christ uses communication as an intrigal part of the Church. When the denomination came into existence twenty-five years ago, as a result of a union of the Evangelical Reformed Church and the Congregational Christian Churches, the constitution called for a national arm of the Church to be created which would be on an equal level with the other national arms of the church. This meant that communication was not to be treated as public relations or as a service arm of the Church, but that it had a ministry of its own.

In the twenty-five years of the existence of the denomination this office has functioned in that way. We participate in the decision making activities of the Church and help people time their news events and frame their resolutions so that they are clear and sharp. This means when something is voted it can be announced to the public and it doesn't take two paragraphs to explain all of the variations and exceptions that may pertain to the action.

In the Iast five years one specific program which was developed was a combined communication/evangelism thrust in the denomination which placed together the concepts of communication and evangelism. This in effect says you cannot have one without the other.

All of the staff members in the Office of Communication have special training in journalism and communication. Many of our leaders also have training in theology.

We seek to have a wholistic approach to communication in both the national aspects of the church as well as the local church. This means that we seek to tell the story of what the church is doing in as many different media as possible. No longer we dare to rely just on print media. 
For each of the national meetings of the church, whether it is of the entire denomination which meets every two years, or any of the arms of the church which meets once or twice a year, staff members are assigned to cover these meetings just like a newspaper/radio/television news department would cover that. We apprise local communication media that we would be in the city by means of an advance story and telephone calls. We follow these up and seek to line up as many interviews as possible in the community with decision makers and news makers who will be in the community for the meeting. We have not had any major problems with getting this kind of publicity in local communities.

Through the EVCOM workshops and a whole series of educational booklets, cassettes, and video tapes we are trying to help local church leaders acquire basic communication skills. We have just been working on this for about five years, but we have seen marked improvements in the communication pieces which have been treated by local and regional unites of the United Church of Christ. We expect to continue the workshop training program in the future.

The people who are involved in communication in the United Church of Christ are viewed as specialists in their fields and we have not had any real problems in terms of acceptance because we have sought to insure a level of skilled and proficiency in those that we have employed to be teachers. In the national adgency, communication leaders of the church are full time employees, but on the regional and local levels these are people who are pastors and lay people or individuals who have administrative responsibility in their particular part of the church.

We believe that United Church of Christ will not continue to grow and become more penetrating in American society unless we do communicate the ways in which we feel God is working through us and the way we are trying to provide help to meed the needs of individuals within the local communities. I am enclosing a copy of the last annual report of our communication office, as well as a list of evangelism/communication resources which we have available in this office.

I trust that this will be helpful in your research work for the Seventh-day Adventist Church.

$\mathrm{EAS} / \mathrm{pc}$ Sincerely yours,

Encs.

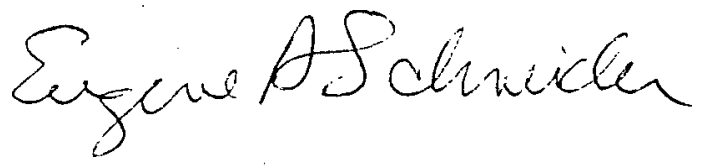


Dear Dr. Meyers:

I'm going to tell you more about penguins than you want to know about penguins, particularly in response to the first of the eight questions you asked in your september 22 letter. The enclosed papers are that response.

Our communications people at the national level are trained in journalism, audio-visual techniques, and radio and television production and programming. All come from a professional background in these fields, with the exception of myself.

We use print and mass media outlets (secular and religious) to tell our story about activities, goals, and services. We never do anything about etc.

As wide as possible publicity is given through all the channels available to us. (See media and target audiences in our communications strategy.)

We think that what the church does and says has an effect on other sectors of our society and we attempt to communicate its (the church's) efforts to those sectors.

Unfortunately, we are too often seen as resource people who churn out news and information that comes through the pipeline. Not much consultation nor advice are sought.

Our people are full-time employees in the communications area. 
We'd like to think that we are going to play a more significant role in the church. The matter is presently under study by a committee that bears the title communication in the Church. If you're interested, I'd be happy to send you some preliminary information on what that committee is up to.

Cordia11y,

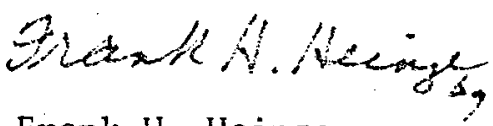

Frank H. Heinze

bg

Enclosures 


\section{APPENDIX $S$}

A COMMUNICATION STRATEGY OF THE UNITED METHODIST CHURCH 


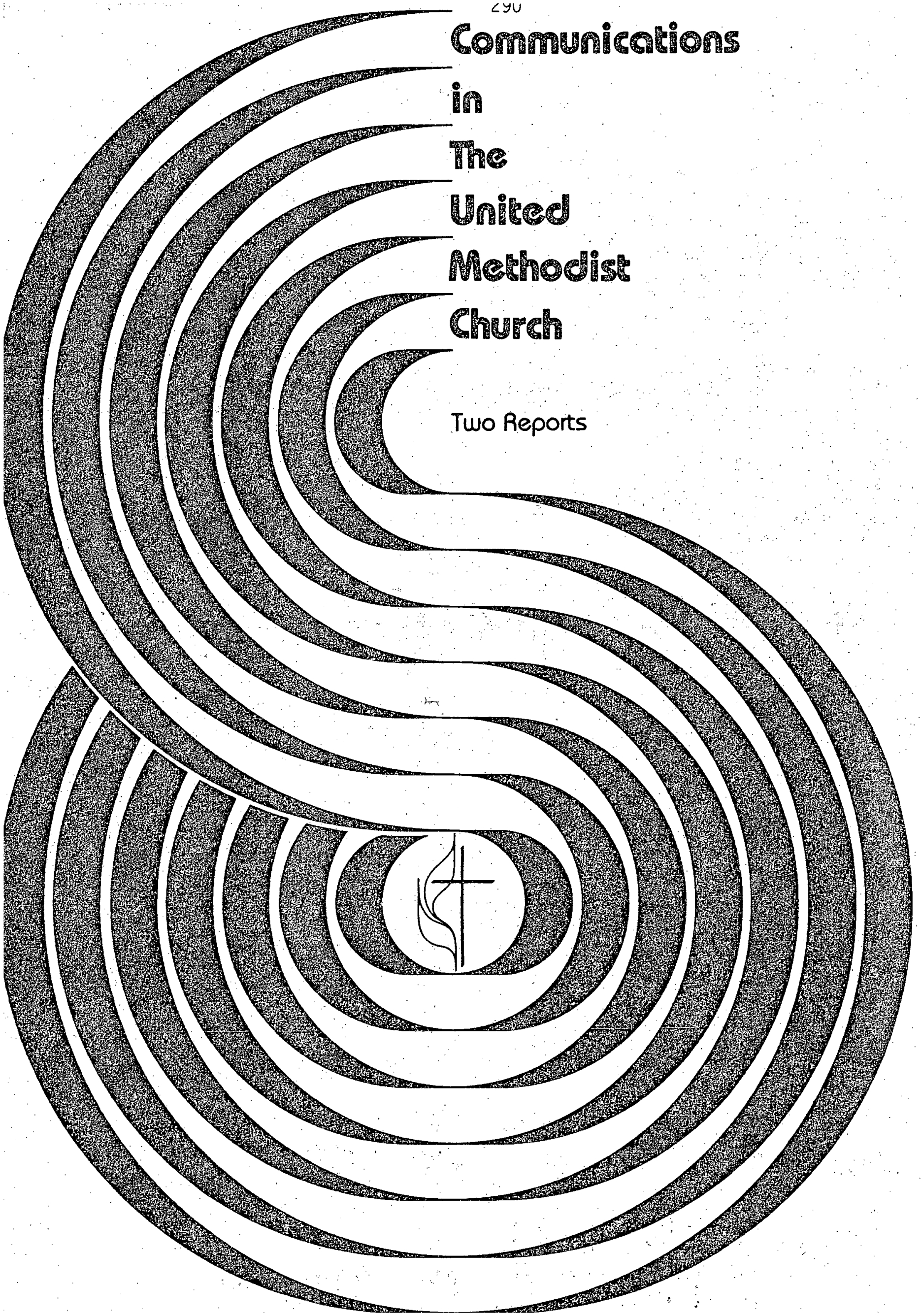




\section{Communications}

\section{in The \\ United Methodist Church}

In adopting this report, the 1980 General Conference called 'or the implementation of a comprehensive communications iystem for The United Methodist Church.

This document is the full report as amended by the jeneral Conference.

\section{Introduction}

The 1976 General Conference of The United Methodist Thurch adopted a number of statements on the field of zommunications. One of these called attention to the systemic relationships among media and asked for a zomprehensive approach to communications for the shurch.

The General Conference statement declares: "The aim of The United Methodist Church is to move toward a zomprehensive system of communications, embracing print, direct mail, broadcast, film, audio, and mixed media. Any decisions for development or funding of any one medium shall take into account its relationship to other media in a total system."

To help the church move toward that aim, the General Council on Ministries and United Methodist Communications have studied what would be required for a comprehensive system of communications. This report is a result of that work.

The work is based upon a conviction that God communicates with persons. God has spoken to humankind through creation, the prophets, covenants with people, the scriptures, and-supremely-through the Son, Jesus Christ. In response to these acts, the Christian must likewise be a communicator. Communication is essential to the church and to the Christian. Ours is a faith that can not be practiced in isolation.

We believe further that communication is a process by which Christians may become a community of faith. Communication is a sharing of self, information, beliefs, and insight among persons and groups. Communication is a process by which the church proclaims the faith and witnesses to Jesus Christ beyond its own walls, to the general public.

From time to time efforts have been made to coordinate communications of the church and bring about a holistic approach. The 1972 General Conference, on recommendation of the Structure Study Commission, created United Methodist Communications and assigned it certain leadership and functional roles. It also assigned to the General Council on Ministries coordination of communication policies and publishing. However, these actions did not represent a systemic approach to communications for the church. The General Church Periodical Publications Study of 1975, commissioned by the General Council on Ministries and carried out by United Methodist Communi- cations, brought in a far-reaching report subsequently adopted by the General Conference of 1976. That report gave the vision of a comprehensive communications system, undertaking to reach all potential audiences and utilizing all media.

The present communication activities of the church, scattered as they are through all levels of structure, have a common purpose. That purpose might be stated broadly as to communicate the gospel, to minister to human need, and to convey information about the faith, life and work of the church. The purpose of a comprehensive communications system is the same. A systemic approach is intended to deal with the fragmented state of our present communication efforts. There is deep concern for making our work of Christian communication as effective as possible, and the lack of a systemic approach reduces effectiveness.

\section{1 - Opportunity in a Revolution}

We are living in the midst of a communication revolution.

The technology of communication is changing, with such developments as fiber optics, facsimile printing, home communications centers, small and inexpensive home computers, video disc recording, two-way television and the use of satellites. At the same time the ways we use information in our society are changing, with significant social and economic consequences. We are moving into an information-based economy and a communicationsaturated culture.

The communication revolution offers opportunity to the church: it places powerful new tools within our reach. The revolution challenges us to maximum effectiveness in our communications and it demands that we lead in the enhancement of human values and the life of the spirit in the face of the potential of a materialistic mass culture.

To work effectively in the midst of this revolution the communication system of the church must be strong, flexible and imaginative. The components must work together well. The financing of communications must reflect a genuine commitment by the church at all levels-local, conference and general church.

A comprehensive communication system to function in this setting will make full use of what The United Methodist Church already has. Most components of such a system are in place. Much excellent work is being done. Yet the sum of the present activity does not add up to a comprehensive system adequate for the challenge of the times. The proposals that follow will serve to develop these components into a system that will function in a style of creative collaboration. They will fill gaps in the present system and deal with problem areas. 


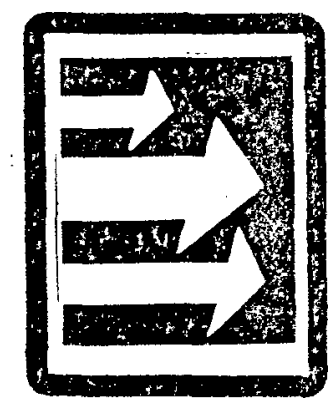

ceadership and Planning Recommendations: A leaderhip role will be assigned to the general church ommunication agency. There will be a forum in which ommunication specialists from that agency, from general rogram agencies and from annual conferences can work ogether on planning and strategies. The style of work mong the various communication units is to be one of reative collaboration.

Concerns: There is need for strong leadership in communications and for denomination-wide planning. Interaction among various communication units could be improved. There needs to be a means of arriving at common purposes.

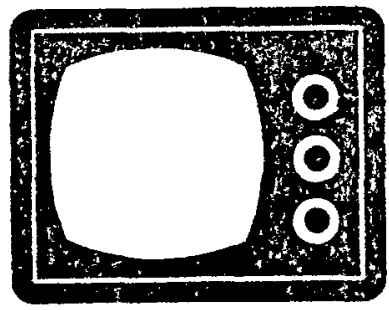

Television Recommendations: There will be a strong new movement into television, including broadcast television, cable, video discs, and satellite transmission. Such a pervasive influence in our culture demands that the church give it major attention. At the local and conference level this will strengthen local and regional broadcasting. At the general church level it will make possible such advances as more program production and placement, perhaps a program series, a West Coast office to exert the influence of the church on commercial programming, and possibly station ownership. There should be more training for broadcasting at conference, district and local levels. If the church takes the challenge of television seriously, it will make major funds available for sharply increased work in television.

Concerns: Television is one of the most pervasive influences of our times. The average family watches television cumulatively 54 hours a week. Yet The United Methodist church is virtually invisible on television and many of its members are asking why the church does not make fuller use of the medium-nationally, regionally and locally. There is little TV programming done by the church for children and youth.

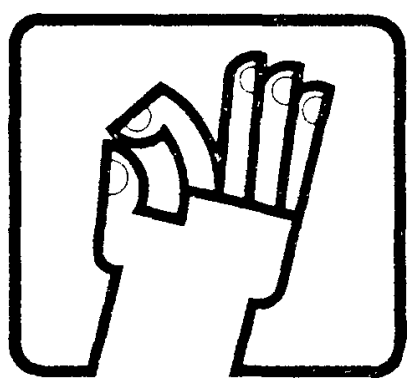

Public Relations Recommendations: A program of public relations for The United Methodist Church as a whole will be designed and implemented by the general communication agency. Local churches, districts, conferences, and general agencies of the church will be involved in the public relations task. While strategies will be developed under leadership of the general communication agency, this agency will not be expected to carry out all of the needed activities alone.

Concerns: Major public relations problems and opportunities are not adequately addressed by the church nationally or regionally. Church leaders and members are concerned that intentional and comprehensive public relations for the church are not receiving the emphasis they deserve.

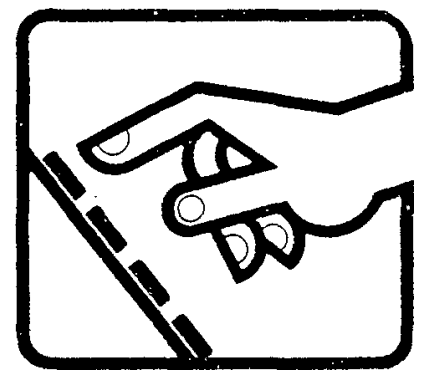

Research and Development Recommendations: Research and development work in communication will be scattered throughout the connection, including research at the annual conference level. Leadership in research is a function of the general communication agency. Certain large-scale research (for example, in new technology), will be directed in behalf of all by the general communication agency, but personnel and resources of other communication units will be involved. Findings of research and recommendations for applying the findings to the needs of the church will be shared broadly.

Concerns: There is need for more activity in research and development in order to proceed more knowledgeably in the midst of a communications revolution. Research needs include study of communication theory and practice; research in communication technology and its application; market research; and study of motivation. In all areas, but especially in technology, research needs to be accompanied by planning for implementation. 


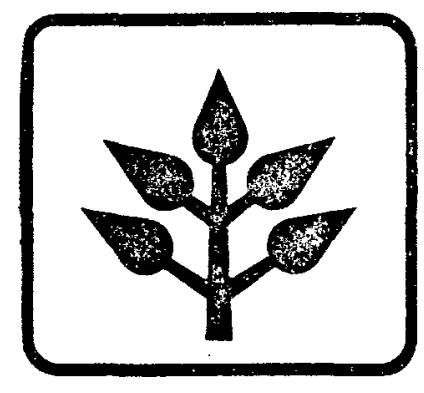

Training and Resources Recommendations: Primary esponsibility for training at the local level rests with he district and annual conference. Committees and sffices for communication in the annual conference will issume an enlarged responsibility. The communication igency at the general church level is to provide counsel, cesource persons, and media resources for training local shurch communicators. Training for area, conference and district communicators is to be coordinated or done oy the general church communication agency, calling apon communicators in other church agencies as resource persons. Production of resources for training in communications is a primary responsibility of the general communication agency, seeking the collaboration of others.

Concerns: Strengthened resources for communications and increased training in communication skills are required to make the church effective in its communication tasks. These needs are especially apparent at the local level, but there are needs also at the district and conference levels.

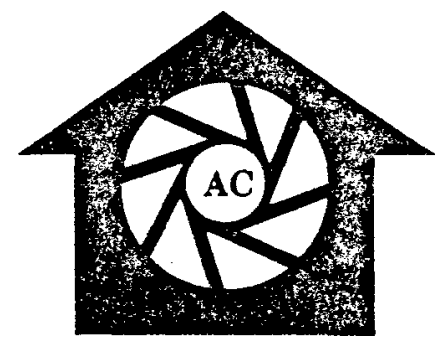

Communication Programs of Annual Conferences Recommendations: Communication functions of annual conferences will be strengthened. This requires that decision makers in the conferences be aware of their opportunities for communications and the special skills required. It is recommended that in providing conference staff, care be taken to preserve a discrete area of communications and keep professional requirements in mind in filling staff positions. The general communication agency will make available consultation and assistance to conferences in developing their communication programs. Guidelines for district, conference, and area communication programs are to be developed by a consultation among persons working at these levels, convened by the general communication agency. Resources for communications at the conference level are to be provided by the general agency, which will also create training opportunities for staff.

Concerns: The church does not have a clear policy on the essential communication responsibilities at the conference level. There are no generally accepted guidelines as to what the communication program should include at the district, conference and area levels. Professional requirements for persons holding communication portfolios in conference staffs are uneven. There is a need for more resources and in some cases training.

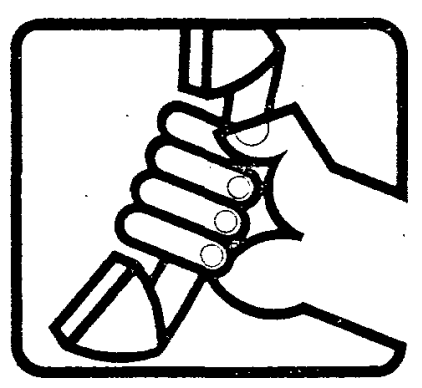

Telecommunication Recommendations: Telecommunications will be addressed as a part of the comprehensive communication system, with attention to such possibilities as alternative trunk lines for voice communication, use of satellite or other innovative linkages, teleconferencing, and the development of models for conducting meetings without travel. A top priority will be development of a voice communication network linking general church agencies at the major headquarters locations in order to minimize costs, improve efficiency and create a basic network that might later be expanded to include conference offices and other levels of the church. The central communication agency, with its expertise in and responsibility for communications, and the General Council on Ministries, with its responsibility for coordination, will be assigned responsibility for development of the basic telecommunication system.

Concerns: Two separate professional studies have shown that telecommunications for the United Methodist Church are disjointed, inefficient and costly. The church has been slow to take advantage of new technology, in part because a variety of individual units devise their own telecommunication facilities. While conference telephone calls are used frequently, the church has been slow to move beyond this device in developing ways to bring people into dialog without travel. 
media channels to inform the public at large who United Methodists are and what we are concerned about, utilizing local persons and locally prepared materials as well as nationally produced resources for input to the secular media; provide news to the public media.

c. Work with local church communication coordinators and committees-directly or through districts-to ensure comprehensive coverage and quality programming within the conference.

d. Publish or arrange for publication of such periodicals as may be needed to inform the local church constituency of conference, national and international programs and issues of concern to this constituency.

e. Encourage distribution and use by local churches of relevant nationally produced periodicals and resources.

f. Produce as needed specialized educational media resources for use throughout the conference.

g. Provide a resource center to serve churches within the conference and offer assistance in use of resource materials.

h. Take initiative in promotion; work with the conference staff and national agencies to coordinate program and benevolence interpretation and fund raising within the conference.

i. Provide training in communications to church groups throughout the conference in cooperation with United Methodist Communications, working through district communication organizations as appropriate.

j. Perform public relations functions for the conference and assist in the public relations of agencies and institutions of the conference.

k. Function as an integral part of the comprehensive communications system, initiating and helping to facilitate a two-way flow of communication between local churches and general boards, agencies and administrators at the general level of the church.

1. Assist the ethnic minority communities within the conference with their communication needs.

m. Cooperate with communication persons in other conferences and at other levels; share resources produced in one conference with others; attend a national consultation convened by United Methodist Communications at least once every two years for communication staff persons in conference or area offices in order to coordinate communications work and advise United Methodist Communications as to its program and services.

3. Episcopal area (using an area office of communication if desired).

a. Perform news and public relations functions at the area level, including coverage of actions of the bishop.

b. Work with Conference Committees on Commu- nications and perform services for the conferences if and as mutually agreed.

4. Jurisdiction (optionally using jurisdictional staff).

a. Use print, film, and other media to communicate internally about the work of the jurisdiction.

b. Communicate externally, in such ways as press relations or radio and television broadcasting, in consultation with United Methodist Communications and with services and resources from UMCom.

C. General church level.

1. United Methodist Communications.

a. Innovation. Use staff and funds in model building and testing, experimenting with options, tools, and styles available from the secular communication industry to determine which combinations best suit the needs of the church as it attempts to speak to the world and communicate internally.

b. Advocacy. In behalf of the church, monitor all regulatory and decision making arenas related to communication and, where possible, influence decisions being made at federal and international governmental levels-including such issues as free flow of information, access to communication channels, and postal regulations.

c. Communication with the public. Set forth to the public at large through the public media the meaning of the Christian faith from a United Methodist perspective; minister to human needs of persons as appropriate, using media; make clear to the public what we believe and who we are as a people by creating messages and developing spokespersons who can articulate our beliefs and concerns.

d. Network building. Create networks of communicators at all levels of the church, including local church, district, conference and national. Networks may be organized around functions, skills or interests and will bring together persons trained in communication techniques and knowledgeable about the denomination, its goals, programs and projects, to give mutual support and strengthen the work of the church in internal and external communications and promotion.

e. Conduct public relations in behalf of The United Methodist Church at the denominational level and give counsel in public relations to other units and institutions of the church.

f. Operate a news and feature service to serve the public and in-church media with impartial and complete news and program coverage of The United Methodist Church, building on what is already in place (existing agencies, periodicals and services).

g. Provide for the denomination instructional and informational materials in forms best able to be utilized by constituents, including video cassettes, motion pictures, filmstrips, audio cassettes, discs, or new forms, working with other 
programs and procedures and sharing together in decisions related to content, format and distribution of such materials within the church.

g. They shall assume responsibility for such fund raising activities of their agencies as General Conference shall assign to them, working in conjunction with appropriate bodies to place such efforts in proper perspective to the total fund raising program of the denomination.

h. They shall cooperate with Uniter Methodist Communications in providing news and feature coverage of the activities of their agency for distribution through channels established by United Methodist Communications as well as their own periodicals.

i. They shall serve as the primary link between the program agency and United Methodist Communications, providing counsel and information in their subject area for use with the public media through United Methodist Communications.

j. They shall cooperate with United Methodist Communications in the training of persons within the communications network in the subject matter of their agency and in securing communications training for their own linkage persons at conference and local levels.

k. They shall work in cooperation with United Methodist Communications and other agencies to do marketing analysis and data gathering on which to base long-range planning for the communications programs of the agency and the denomination.

1. They shall participate in the Communication Advisory Committee.

4. The General Council on Ministries.

a. Perform the tasks of evaluation and coordination as a part of its work in those areas applying to all agencies of the church. This includes resolution of conflicts between agencies in the area of communication if such conflicts should arise.

b. Perform the disciplinary functions in the area of distribution of free literature, proposals for new periodicals, and coordination of mailings.

5. Communication Advisory Committee.

A model for coordination should include provision for:

a. Accountability and responsiveness to persons in the local church who contribute their funcls.

b. Recognition that ideological differences exist and there must be ways for interaction among leaders and constituencies who do not want to see information they disagree with disseminated or programs they do not like supported.

c. Provision for the freedom to move ahead by individual agencies able to get agreement around a particular set of goals.

The Communication Advisory Committee shall be created by and advisory to United Methodist Communications to work in the areas of planning, coordination and arbitration related to the message sending aspect of the communications enterprise. This committee shall be composed of representatives of United Methodist Communications and staff of the several communications units at the general agency level, communicators at the conference level and such other persons or organizational representatives as may be deemed advisable. Functions shall be:

a. Meet regularly for the purpose of sharing information, mutual planning and coorlination of the communication thrusts of all agencies in order that gaps may be filled and werlap diminished.

b. Study information overload and communications flow and advise action.

c. Study and advise as to ways of reaching marginal audiences gathered around the local church in ways which challenge and invite participation in national or conference programs if local programs do not exist.

d. Examine the interface between education and communication systems and, with United Methodist Communications, advise how technology may be employed.

e. Study the ways local congregations are resourced and the interrelationships between education and fund raising, giving advice for action.

f. Work with United Methodist Communications to strengthen conference and area communications enterprises.

g. Study ways to achieve a higher level of two-way communications.

h. Provide an arena for the evaluation of the total communication efforts of the church in accord with mutually agreed-upon guidelines and for sharing of self-evaluation models.

D. Unofficial structures.

The category acknowledges the very important roles played in the communications of the church by publications and broadcast efforts that are not authorized or funded by central agencies but serve United Methodist constituencies. Included are such periodicals as independent conference publications, United Methodist Reporter, NOW, Good News, and many others. 1. The United Methodist Association of Communicators, as a voluntary, unofficial professional organization.

a. Provide recognition, fellowship, and vocational enrichment for professional communicators of the church; participate in and support training and continuing education events.

b. Develop standards and see': to enhance the professional quality of work by United Methorist communicators.

c. Cooperate with communication offices and structures at local, conference and general church levels, with a specific liaison to the central communication agency.

d. Assist in monitoring and evaluating the communications efforts of the church.

e. Assist in keeping membership up-to-date on developments in the communications industry and in promoting dialogue and discussion on 


\section{APPENDIX T}

A COMMUNICATION STRATEGY OF THE UNITED PRESBYTERIAN CHURCH 
TOWARD A CHURCHWIDE COMMUNICATIONS SYSTEM: A STRATEGY

I. The essence of communication is an exchanging of awareness.

On that basis, the purpose of communication in the United Presbyterian Church is to make all of its parts aware of what is being done in its other parts.

Such communications may serve many aims. Among them are the eliciting of personal and corporate involvement in mission and ministry; broadening understanding of often-complex issues; contributing to the wholeness of the United Presbyterian Church in all its parts, and of the Church Universal; eliciting financial support for mission and ministry, through understanding; and not least, reporting to the church on the agencies' stewardship of the responsibilities and the funds entrusted to them.

Communications, especially communications in the church, must walk a narrow and often ill-defined path. It has a responsibility for building trust, but not at the expense of integrity; it must speak the truth in love, but not to the derogation of either love or truth; it must clarify, but not over-simplify; it must be supportive of programs, but not through propaganda in the pejorative sense of that word; it must encourage financial support, without hiding or glossing over that which is unpleasant; it must encourage discipleship, without promoting any of the elements of discipleship at the expense of the others.

II. A churchwide communications strategy is designed to do the following:

Listen--hear what is being said in the church, to the church, by the church, so that understanding may take place.

This listening will be undertaken in a variety of ways among which are the following:

1. Existing research instruments, primarily the Presbyterian Panel.

2. Intentional inquiries by staff in their travels, seeking out local church members.

3. Recording pertinent data found in the reading of congregational, presbytery, and synod publications.

4. Analysis of subject matter of articles received by MONDAY MORNING.

5. Analysis of the concerns expressed by church members in their letters to General Assembly agencies, insofar as the agencies are willing to provide access to such mail.

6. Analysis of inquiries received through Dial-Your-Question. 
2. Begin, in October, a series of reports intended to cover a period of one year.

a. It is understood that circumstances such as the emerging of new issues, concerns, and subjects may change the 1 ist of topics to be reported.

b. As part of its mandate assignment, the Communications Unit will determine the means, timing, and persons assigned to carry out the reporting function, but always consulting with and seeking the cooperation and assistance of all the agencies.

Stimulate--encourage the interchange of ideas, responses, needs, hopes, expectations.

1. A primary element in the selection of means by which reporting is to be done will be consideration of ways by which response can be elicited.

2. Responses will be reported back to the church, as well as to the agencies and cabinets, with emphasis on reporting to those most involved in a particular subject.

Innovate--constantly seek new ways, or different uses of old ways, in listening, anticipating, reporting, stimulating.

1. It is recognized that budget and staff limitations may impose restrictions on the innovative expectations; nonetheless this function will be agressively and continuously pursued.

2. It is recognized that none of the above is to be understood to be accomplished at the expense of current agency or unit goals, objectives, and responsibilities, but rather will be undertaken in addition to those services.

3. It is understood that the addition of the services outlined in this paper have budget implications, and that the success of the project depends at least in part on funds made available for it.

III. All communicating is done through one or more of four basic means:

That which is spoken, written, depicted, or enacted. That they sometimes overlap does not deny their individual integrity; that they often are combined underscores the importance of variety in making the exchange of awareness possible. These means are involved, in varying degrees, in all the components of communications strategy.

Any system to be developed at all judicatory levels to make workable a churchwide communications strategy includes the following components:

1. A communications presence at and access to planning and decision making points.

2. Determination of communications content in materials being developed for churchwide use. 
other agencies with whom they meet, thereby lessening the time available for in-depth discussions of both issues and possible communications regarding them.

There is neither personal 1iaison with the synods (and presbyteries), nor representation by those judicatories on the Common Concerns Group.

No group such as the Common Concerns entity exists in relation to other General Assembly units beyond the Program Agency.

There are insufficient numbers of persons in synods and presbyteries who have either sole or primary responsibility for communications to adequately involve those judicatories in churchwide communications considerations.

Despite good will and good efforts, there remain instances when "fire fighting" communications efforts are necessary, and such efforts are less effective than well-planned, coordinated, communicating and interpreting.

2. Determination of communications content

A. Present situation

The Communications Unit consults and cooperates widely in determining content of communications. Counsel is sought as to the sensitive nature of projects, the specific opportunities or problems, and other ramifications. Cooperation of other units in these matters is commendable when sought by the unit, and some of them increasingly seek similar counsel from Communications Unit personnel.

The preparation or rewriting of materials by unit staff members is sought frequently, particularly in the area of written documents.

B. Problems

Although the mandate given to the Communications Unit appears to give the unit responsibility for determining communications content, no such authority is extended to it. This is as true at the General Assembly level as it is at the other levels of the church, particularly in some middle judicatories.

It is obvious that A.D. magazine is a key element in a churchwide communications system, since it reaches and is read by more United Presbyterians than any other official medium of communications. Yet, in the area of content, the determination of issues to be addressed and developments to be publicized are entirely the choice of A.D.'s editors. This is not to say that those persons are not sensitive to what is happening in the United Presbyterian Church; they are. It is to say that there is lacking a channel of regular communication and coordination between A.D. magazine and the unit of the Support Agency responsible for developing and implementing a churchwide communication system. 
B. Problems

Aside from those publications provided through the Communications Unit, coordination of materials reaching church audiences is haphazard, at best.

One neglected medium of communication is that classified as electronic, embracing radio and television. The problem of financing such work, however, is great. Ways need to be found to communicate with United Presbyterians who are among the owners of an estimated 120 million television sets and 431.1 million radios in the United States.

There is a plethora of specialized publications for specialized audiences, from General Assembly agency units--evangelism, vocation., and Christian education, to name only a few. It would not be infringing upon the rights of such units to arrange greater coordination and exchanging of knowledge about what is being said to whom.

The same may be applied to synod and presbytery publications and other communications.

Consideration also needs to be given to more effective ways to reach audiences through local church sources, primarily newsletters, with news and information about the larger church including presbyteries, synods, and General Assembly agencies.

The quality, content, style, and form of documents reaching congregational audiences is uneven, and the selection of audiences is often without coordination. Consulation with the Communications Unit can be of assistance in these areas.

4. Determination of the means of reaching the audience or audiences

A. Present situation

Whether a specific communication should be undertaken through persons, printed, or audiovisual means (or several of all of them) is an early consideration in each instance in the Communications Unit. The subject matter, the availability of funds, and the time factors are all a part of this consideration. Judgments then can be made as to the effectiveness of a given means of communication for a specific need.

Several agency units present their concerns to unit staff and seek advice on what method is best.

\section{B. Problems}

Insofar as communications addressed to church audiences by various other units is concerned, it is at least a question as to whether any informed consideration is given regarding what means best will serve the purpose. A coordination. function is reeded.

Consultation on the part of synods and presbyteries is rare, understandably so considering the absence of staff persons at those levels whose primary 
Synods and presbyteries often pay too little attention in their communications to the concerns of the larger church.

Commissioners to the General Assembly are not used as communicators/ interpreters to the most useful extents possible, although they are potentially among the most effective communicators available to inform their parts of the church of the life of the rest of the church.

Prepared 1978

Revised 1980 
- APPENDIX U

A COMMUNICATION STRATEGY OF THE SEVENTH-DAY ADVENTIST CHURCH 
It's all there--everything we need to reach the world's inhabitants with the distinctive gospel of the three angels.

Satellite broadcasting, network television, mass circulation magazines and newspapers have combined with a wel1-developed printing industry capable of producing brochures, advertisements, handbills and other tools to make the opportunity of reaching all mankind well' within our grasp.

Increased availability of education has created a demand for a specialized technology, producing a communication explosion unparalleled in human history. Emerging societies as well as those enjoying industrial sophistication are increasingly dependent upon communication to meet the needs of everyday 1 ife. Indeed, people are literally surrounded by thousands of specialized messages in the form of advertising, literature offers, music, commentary, public affairs programs and news.

The statistics in the United States alone clearly point to a growing dependency on mass media:

- There were 8,408 radio stations operating in the country at the end of 1977. Of these, 4,508 were commercial AMs, 2,986 were commercial FMs, and 914 were non-commercial FMs. More than 71.6 million homes were equipped to receive broadcasts from the nation's 996 television stations. The average American 
Report--2

household watches television for six hours and four minutes each day, according to A. C. Nielsen statistics. And the latest study by The Roper Organization (commissioned by the Television Information Office) shows that 64 percent of the U.S. public turns to television as the source of most of its news, and that 51 percent ranks it as the most believable news source. ${ }^{1}$

- People are also turning to an increasing number of special-interest publications including 1948 daily newspapers, 9,301 weeklies and 4,331 monthly periodicals. 2

At the hub of America's communication industry is Madison Avenue and the Avenue of the Americas--a staggering array of facilities and human potential with the unprecedented power to reach out and mold the lifestyle and thought patterns of virtualiy every member of society.

Emanating from this creative complex is a seemingly endless stream of messages--carefully researched and developed to capture our imaginations--urging us to buy, support, change, accept or reject. Never have so few urged so many to buy so much as the U.S. communications industry.

BBroadcasting Yearbook, 1978. 2Ayer Directory of Publications, 1978. -more- 
Yes, it's all there--waiting to be used--for political gain, commercial enterprise or self interest. For building up or tearing down. For good or evil.

Surprisingly, those who have the most to gain from intelligent use of the media have done the least with the resources at hand. For instance, church-related groups have, with the exception of occasional evening slots or religiousoriented stations, usually appeared on little-watched Sunday morning schedules.

Our own denomination has used a scattered approach through radio and television broadcasts, each doing a fine job, but often unrelated to one another and, thus, lacking the powerful thrust needed among the many voices competing for attention today. We also tend to emphasize the communicative act itself while ignoring the other basic principles of professional public relations-research, planning and organizing, and evaluation. If we continue to emphasize column inches while ignoring more important issues of effectiveness and image-building, our impact in the communications arena will continue to be small.

Lacking on our part has been a vision of the potential to reach people with a centrally-directed, carefully targeted, ongoing campaign carrying the greatest of all messages, the gospel, to mankind. 
The Seventh-day Adventist Church is in a good position to fill this void by developing a package of relevant materials designed to have a positive impact on society.

We have the talent: Communication specialists abound in our hospitals, schools, conferences and other entities. We have the tools at our fingertips. We have the message. And we have the organizational ability.

Presented here, in outline form, is a strategy designed to blanket our planet with the unique message of the Seventh-day Adventist Church. The best available communications talent would be involved, as well as every church administrator, pastor, evangelist and layman in all parts of the world. Central to the success of this endeavor is the coordination of the Church's many resources as well as utilization of a broad range of communications media for the widest possible exposure.

Objectives of this all-out communication thrust are:

1. To reach every man, woman and child with the gospel message within the space of a relatively brief time frame.

2. To portray, in a clear, simple way which relates to all people, the special teachings of the Seventh-day Adventist Church.

3. To mobilize the Church so that all might participate in the finishing of the work. 
The Plan

I. Create a unit within the General Conference communication department with the specific responsibility of planning a wide-ranging, ongoing media effort designed to accomplish the above goals.

A. Functions would include research, idea development, planning and organizing, and production and supervision of various thrusts to be detajled below.

B. Specialists trained in journalism, broadcasting, public relations and advertising should form the staff.

c. The unit will be directly responsible to the chairman of the communication department and, through him, to the president of the General Conference.

II. This unit would assist the General Conference administration in laying the foundation for a successful thrust by cultivating the ranks of the Seventh-day Adventist Church itself. Key concepts in this effort would be organization, coordination and mobilization.

A. Dialogue with all levels of church administration to determine the present state of the church, current plans and expectations for finishing the work, and ideas on how to better work together to successfully conclude our earthly ministry. 
B. Strengthen the channels of communication with lay church members by asking them, by use of a scientifically verifiable questionnaire, what their perceptions are of the church's evangelistic performance and how the work might be strengthened and successfully finished.

C. Prepare the membership for the coming campaign through internal publicity intended to heighten membership interest in witnessing for church growth.

1. Articles on family living, evangelism and witnessing would appear in union conference papers as well as the Adventist Review.

2. Audio visual programs in Sabbath schools, etc.

III. On the basis of this research, the unit would, in consultation with General Conference administration, develop a communication plan with a world-wide scope. A major effort, using all appropriate communications media, would be planned and directed by the General Conference communication department. The objective would be to reach major population centers on every continent, primarily radio and television broadcasts. Less populated locations would be covered by radio or other means. Supporting communications in the form of advertisements and articles would be strategically placed in mass circulation newspapers and magazines. Promotional 
material to build audiences would include spot radio and television announcements, newspaper and magazine advertisements, and handbills/leaflets distributed by local church members. Follow-up materials after each major broadcast would include articles and supplements in newspapers and magazines, and related programming on established denominational broadcasts such as Voice of Prophecy, Faith for Today, It Is Written, Adventist World Radio and the network of Seventh-day Adventist college and university radio stations.

A. Using a central theme, a series of quarterly television broadcasts would address problems of everyday life as they relate to the Bible with constructive solutions offered in a Christian context.

1. Family living/raising children

2. Health
a. Exercise
b. Physical, mental and spiritual well-being
c. Diet and temperance
d. Recreation

3. Satisfying interpersonal relationships

4. Work/career selection--making a living or serving society? 
5. Retirement and old age

6. Happiness as it relates to wealth, material possessions

7. Crime and violence/cruelty

8. Divorce and remarriage

9. Facing adversity--an approach to personal tragedy

10. Self-determination--in God do we trust?

11. Liberation--with a Christian perspective--for men, women and children

B. Format to be modern, appealing to broad cross-section of the general population. Discussion with dramatized illustrations should be professionally scripted using the best actors, musicians, and production capabilities the industry has to offer.

c. Message should be tailored to the cultural background and socio-economic conditions reflected on each continent.

D. Satellite broadcasts should be planned to cover every major continent.

E. Use national television networks and existing outlets such as Adventist World Radio to cover major population centers. 
1. Prime-time television, drive-time radio. Half-hour and one-hour television programs; 30 and 60 -second promotional spots on radio and television to build audiences .

F. Marshall resources of existing church-sponsored broadcasts as a backup to tie in with central theme and heighten listener interest in other church-sponsored programs.

IV. An extensive follow-up campaign should be mounted to augment this media coverage. In-depth treatments of subjects previously presented would be combined with practical steps toward a better life. Reponse mechanisms would be included to enable readers to obtain further information from a central clearinghouse.

A. Articles, advertisements and supplements should be placed in national magazines, such as:

1. Reader's Digest

2. McCall's

3. Better Homes and Gardens

4. Good Housekeeping

5. Newsweek/Time/U.S. News and World Report

6. These Times, Signs of the Times

7. SDA publications such as Voice of Prophecy News, Faith for Today Telenotes 
B. Brochures, pamphlets and books would further embellish established themes.

1. Published by denominational houses.

2. Perhaps a series on each topic.

3. To be distributed as responses to inquiries and as handouts by church members at public gatherings, to friends and neighbors, in business concerns and professional offices.

4. Series to serve as a cultivation device for evangelistic meetings.

C. Other media should be employed to further extend this blanket coverage.

1. Billboards

2. Posters

3. Flyers

V. Related materials should be prepared to form the springboard from mass media coverage into a dynamic, coordinated evange istic approach.

A. Brochures and booklets, expressing the established themes, would gradually lead the reader to accept an offer of Bible studies or an invitation to evangelistic meetings.

B. Bible studies and meeting topics should be interrelated with established themes: 
c. Follow-up and encouragement to members in union and division papers, as well as the international editions of the Adventist Review should be carefully planned.

D. Educational institutions should be mobilized to observe the campaign's progress, to assess effects, and to involve students in appropriate practical aspects, training them to continue this work in the future. Theology students and evangelists should be included in a meaningful way so that a greater understanding of the coordinated campaign would be gained.

Summary

As Christ urged his disciples to "Go ye... and teach all nations," so must the modern-day church conceive and execute the communication of the gospel on a global scale. Every unit of the denomination--from the largest division to the smallest district--must be actively involved if maximum impact is to be attained.

We are to be partners in the work of God throughout the world; wherever there are souls to be saved, we are to lend our help, that many sons and daughters may be brought to God. The end is near, and for this reason we are to make the most of every entrusted ability and every agency that shall offer help to the work. 5T, 440. 
Report --12

323

With member enthusiasm and involvement, directed by a strong central administration, the communications commission will be greatly enhanced and blessed. To this end, let us direct our resources in these last days ahead.

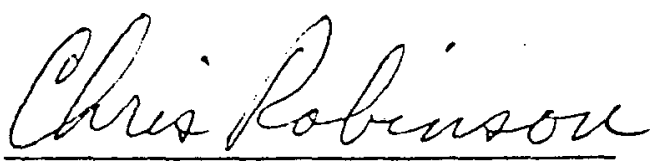

Chris Robinson

Public Relations Director Andrews University 
APPENDIX $V$

A STUDY CONDUCTED IN AUSTRALIA CONCERNING BASIC ATTITUDES TO THE SEVENTH-DAY ADVENTIST CHURCH 


\title{
I
}

\begin{abstract}
A STUDY OF BASIC
COMMUNITY ATTITUDES
\end{abstract}

AND THE SEVENTH-DAY

A DVENTIST CHURCI

September, 1973.

Prepared for:

The Greater Sydncy Conference. Seventh-day Adventist Church. 84 The Boulevarde. STRATHFIELD.

phone $\quad 747.5655$

Prepared by: $\quad$ Dr. Peter Kenny, R. A. M. D. (Sydney) 
CONTLNTS

SUMMARY AND RI:COMMENDALIONS

MAJOR NEED AND ATTITUDE CATECORIES WITIIN THE COMMUNITY

TIIE POLE OF IHI: CIJURCHES IN MODERN SOCJETY

COMMUNITY ATTITUDES TO THE ADVENTIST CHURCH

AN $\triangle$ SSESSMENT OF ADVLNTIST IJTERATURE, AND

MARKETING MATERIAIS. 


\section{1}

SUMMARY AND RECOMMENDATIONS

Attempting to assess the makcting performance of a church raises sonte unusual problems. Whilst it is quite proper to gange how well die church communicates ideas and activitics to its publics, in is not proper to question the clurch's core of docirine. Never-the-less, lliere need not always be a completely sharp break between doctrine and the way it is transtated into messages and activities. Shifts in emphasis may be possible at the presentational level without Joing violence to basic beliefs.

The Seventh-day Adventist Church las a very large problem, and a very large oppormnity.

Imagine a jig-saw puzzle whose pieces are scarrered all over a room. And matiy of the pieces are face-down. No-one las ever seen the complete picture, and no-one has secu the rame on the picure. This jig-saw is your Church, its beliefs, acivitics, and nucssages. The picture does not hang together in any way: the Church has literally no clear identicy whatsocver to Sydney people. Lacking any clear pientre of the Adventist Clunch, people simply confuse it with other unusual-sumding secis. This confusion is nor complimentary to your Clurch. because these unusual sounding sects are generally seen as radical and peculiar. Your lack of identity is as completc as we have ever come across, and the "marketing" consequences are obvions. Though you work hard in the myriad activities you espotse, the ripples are not self-sustaining. Inpace of individual activities is gujckly blunted, and the looked for "chain teacion" never lappens. Onc of the basic facts of marketing is this - you must reach a level of impact on like public: where you becoune a talking-point in a sufficient number of quarters 
to bring about an explosion of awaremess. Products, services, or ideas which do not reach this level tend to plug along in a static way, always below lice level of conmunity consciousness.

At the moment, your Church is well betow the impact level needed to bring about public awareness and a clear identity for the Church.

The problem having been stated, what can be done? As yon will sec, this raises another severe dilemma, Going back for a moment to the jig-saw pozzle anilogy - of all the pieces scattered around, lhere are a few which command attention in vacuo because they happen to contain a sharply interosting minjpicture. In this way, activities tike the stop-smoking programme, and some of the "better living" messages (avoid heart allack, etc.) strike home as very relevant 10 a cerlain sort of person (the harassed businessman or his wife). And some of the material for young people is quite good in a communicalion semse. Pul liese are isolated and narrow-focus impacts which do not multiply into a tolal message. because their content is directed at the extreme symptoms of the hmman predicament. the tips of the icchergs.

Because these messages never seem to rise about lle isolated llemes level, the church's impace through such messages is heavily damped down. The point of presciting many specilic messages does not escape us: we realise it is benter to be specific than abstract. But if the messages are never more than specific. they will, of course, never add up to anything.

People in thcir middle years are so busy and preoccupied with achieving things that they are not interested in the complex of issues which could be labelled "the quality of life". Under pressure, lhey are aware of the extreme symptoms of their 
pressure, so they can be captured by messages about smoking, lieart attack, even healthy foods. But they don't sec any further than the immediate emergency implied in these messages.

By contrast, the old and the young are surprisingly concerned about the "quality of life". They do not believe that things are getring heller every year; they believe that many lhings are gething worse. Though only one in a llowsand tas gone deeply into the probably calamitous future of affuent socicties, a surprisingly large proportion of the young and the old are sure vlat we need to reserve many of of our valucs, and to seek a simpler healthier, less competitive life, with the accent removed from the striving for material gain. We were surprised at the strength of this feeling aniongst the young and old people approached in this srudy.

Though the young and the old have these feelings, they don't kniow what to do. They are wating. it seems, to be cold what co do, or to be organized fisto a framework and discipline which faces the cliallenge of the future in a way relevant to their concerns. But most of them react badly to the language of religion and to the cliche concepts which they recognise in most refigious painphlets. The jueas hidden behind the biblical language of Seventh-day $\Lambda$ dventisin are compellingly close to the emotional needs of the young and old who are concened ahout the nncrace of the future. From our print of view. it is easy to imagine $\wedge$ dventist doctrine re-worded as a disciplined social programme to prepare people for a stringent future. So re-worded, your doctrine would lave high impact on many people. $\Lambda s$ it is now expressed, not even those with obvious concern ahout the future can swallow it. Unformately, young people have learned the habit of rejecting religious-sounding arguments, irrespective of their contents or merits as argunents. Though we may now be pressing proptiety rallicr closely. we must say 
that the Seventh-day Adventist Clurch seews to put forward very relevant principles in an unformate way.

The plitosophical issues raised by these comments are formidable. We musr. of colrse. sidestep them, because our responsibility is to help with MRLSENTATYON and not with basic beliefs. But we must at least raise the question of whether Adventist doctrine can be re-statcd in a way which does not autonarically swich off those prospects who are looking for a disciptine relevant to die entrerging future. Another way to pur it is that Adventism is much bether than it appears to be and much much better than it is known to be. Despite obvious allempts to kecp up widh the times, it reruains awkwardly old fashioned in its presentational strategics.

Whether or not the presentation of doctrine can be renewed, membership would cerrainly respond to a clear and strong identity for your church. And the best way 10 do this would be to label all your activities as Adventist, and educatc the public in a siluple way about the "range" of dings you do. This range of Advenist activities would be presented as exeniplars of the nany new values we must develop as a community.

If you don't develop a clear, and strong identity in the public mind, you will not enjoy a good level of membership growil.

\section{Recommendations}

- Examine the possibility of re-stating Adventist doctrine for llic young concerned group described in this report. The opporunity secms considerable with this group. because your doctrines parallel their perceived needs. 
- Tell the public about all the things you do. Show thent the whole picture. label it all $\Lambda$ dventist, and slow how it relates 10 our most pressing precicamenus as people in a vine of formidable change.

These are recommendations in principle. Precisely how they would be done can only be settled by testing specific attempts. 
Various sections of the community sec vastly different factors as being the most important issues in their lives, and their worries and problems also vary grcatly. The inajor factor that secrns 10 cause thesc changes is age. Young single pcople and old people are far closer in their sense of values than are the middle group composed of then and women with children living at home.

We will deal separately with each sector, and at the end of this section will draw together the most significant and common factors within each gromp.

Married Men, aged 30-50

The most important ling in ale lives of men in this period of lleeir lives is health, and it is also their greatest worry. All else depends on their health -. the support of their family. good relationships within that family, their work, and their relaxation. Their children and their wives are next in importance 10 söme; to others their work and "getting ahead" arc more important than family. Relaxation is also important to them, whether it be sport or drinking. which appeat to be the iwo favourite pastimes of many Australian inen.

Although they regard health as so vital, they often neglect it:

"l haven't got ime to see a doctur, and 1 know l'in sick but he'll slop ine working". 


\section{7}

Work - and the money and security it brings - is so important that many men will sacrifice everyluing for it.

Many lave so many financial comminnems that lley feel forced to continue at all costs, and il is only when they are jolled oul of this behaviour that hey temt to change their values.

"I got sick and only then did I realise llat iuoney is Not all; who'tl support and tove my wife and kids if l'II dead"?

Married Women, aged 25-50

'lheir children are by far the nost important factor in the lives of women in this age group.

"When you've got a young family you put your head under the mat. Flicy're all that matter."

Everything else revolves around bringing up these children, and lheir grearest fear is in failing as a mother and secondly as a housewife. They are generally highly overprotective to their children and often exclude their husbands to a certain cxienr because of this.

"My liusband's got his work, and I've got llie kids. We don't have much in common to talk about at the end of a day". 
Yet althongh they are so fully committed to their role as mothers, they often scem unlappy and resentful about this role.

"l'm so committed to my family that I can never really live my own life".

"My family don't appreciate me - that's my biggest problent in life".

"If you're a mother you're always on call, and no-one helps you".

Bccause of this rescntucnt perhaps, they are quite critical of young people in general. They feel there is a general lack of responsibility and discipline anong them.

"Young people have no principles".

"Kids today don't know what lliey want to do: they're aimless. directionless".

"Therc's a pressure on wormen today to do something".

"lf only someone would organise us or tell us what to do. we could really make things happen".

Religion seems to have more relevance to women than it docs for men, and many of then practise various faiths to various degrees. There is quite a lot of dissatisfaction, however, with 
established religions and churclimen. Women are looking avidly for a faith that will unify and assist their fanilies.

"Everything is getting ont of control, going faster and faster. We seem to have left a lot of good things behind in the nush".

Young Single Pcople. under 25

Young people have a much broader and less materially based view than thuse in the family oriented group.

They are concerned abuut world problems - war, pollution, over-population, apathy, the enviroment, the guality of life.

They want goals, but not material goals. They ace looking far spiriual values, something they can believe in.

Friends, a peer group that they can relate to and feel a pars of are important, and enjoying themrelves in the context of this society is also important.

"Love" is the message liey are interested in, and music is often a part of what they feel is recessary to this context.

"Christ's message was 'Sove one another'. If there was a church that practised that l'd join it". 
Work is not really inportant. just a means 10 an cud for the majority of young people. They dislike the fact that money is uscd as a social rating.

"lid be better if llere was no money. Ilicn people wouldu't judge you hy what yol've gol".

Contrary to what older people believe, young people are decply disturbed at the lack of morality in modern socicty.

"Pcople make decisions now on social standards, not religious or moral".

"Freedom from strong codes of behaviour makes bad liings coinmon".

Jut, although they may have different values and aspirations to the older generation, ilve greatest worry of young people is also ilic furure.

"Everyone is moving, clanging. No-one knows where they"te going. Where will it all end"?

"It's all going to bust wide open soou. if people don't stop going on the way they are". 


\section{1}

Older People. 50 t

Old people of both sexes are quite close to young people in Uheir views. Like them they also are not concerned so nuch wirh nalerial things as with spiritual.

"We're old enough to know that material possessions don't matter".

Faitl is important to old people; in a Church, in humanity, in something stich as strenglh and dignity of soul.

Frecdom is also junportant; as old people they fecl that freedom and beir sighis are often taken from them. And ime is also inportant, time 10 think, to he alone, just to live a Jecent life.

"Jeople make so many demands on you when you"re old; or else treat you as a person willout rights".

The thing old people worry about most is survival.

"I worry about keeping fit and healtby, not being a burden on the younger ones."

"An awlul problem is having an active mind locked inside a quickly failing body". 


\section{2}

Old people atso feel that the values of the world have changed. People no longer aspire 10 "goodness", no Ionger seem to adlicre to moral codes.

"The fabric of socicty is roten; ii's only kept whole by creating new wants".

"The tradition of "Excelsior" is dead. Now it's what you possess that matters in the eycs of the world."

So despitc the many differences between the various age groups, three things emerge as important and of deep concen to all of thent.

Firstly, the future, and the quality of life that will exist for future generations. Secondly, the changing and diminishing sense of moral values, and the fruitless search for something on which to base lhese values. Thirdly, the concept of time ever-accelerating, and low the important things of life are lost from sight because of this lack. 


\section{.13}

\section{THE POIE OF TIE CHURCHES IN MODERN SOCIETY}

The churches are seen as no longer relevant to modern life; the material pressures, moral values, attiudes 10 work and living are not reflected in the teachings of the churches. They are out of touch, and do not communicate in words, ritual or deed even with many of the people who atuend them. Young people in particular find the churches irrelevant and periy.

"They"re hung up on social rules, like not being allowed to dance, and lley're lacking in real love and Christian feeling".

The churclies themselves are seen as breaking God's laws, condoning wars and orher evils, making moncy, getting into political crises.

There also seems to be a general disunity of belief even within clurches that turns many people away. Worst of all. Where is a strong feeling of miles, 100 many don'ts.

"A more modern idiom is needed; we're all a bit fed up with the ihou-shaltnut". 


\section{4}

\section{COMMUNITY ATTITUDES TO THE ADVENTIST CHURCII}

The majority of people are vastly ignorant about the Seventi-day Adventist Church. Basically, the $\Lambda$ dvemtists are grouped with "those odd religions". and peoples' opinions toward theon are coloured by thair opinions towards all other "odd" ones.

A fow general facts emerge that are fairly widely known. Adventists are thought to be a close-knit group, whiclt gives the church a sonewhat exclusive forbidding overtone.

"They're a very close race, they don't inix much with otlier people".

They are regarded as being somewhat introverted, and perhaps our of step with the rest of the world. They are thought to be pretty biblical in the basis of their faith, but few people have seen a church belonging to them. A few people know that they engage in missionary activities. Apart from those on the North Sluore, most people are unaware of the connection with the Sanitarim. This also works vice-versa; people In Sanitarium shops were also unaware of the connection with the Adventisi chutch. Hecause people know so fitule about thent, the general feeling is:-

"They tend to be a bit worthy, a bit less tolerant than other religions".

The beliefs of the Adventist Church are Houglu of as a series of "don'rs". several of them erroneous;

"They don't smoke, they don't drink they don't eat meat". 


\section{5}

"They don't eat, drink or be merry"!

"They don't believe in bloud transfusions".

"They don't have sinday on the same day as us: they have Sunday on Samuday".

"They don't believe in doctors".

"The women don't wear make-up".

"'lltey don't cut their hair".

"l'hey don't vote".

"They don't wear underclothes".

The most common confusion occurs between the Adventists and the Jeliovah's IVitnesses. This is unfortunate, as lie wimesses are the most widely disliked of all religious groups.

Other things that people associate with the Adventists are anti-Catholic, health finatics, faith heaters, non-Christian and child exploiters.

"Thicy were very anti-Catholic at one stage: Catholics were barred from thic Itealth Foot shops, and pictures were circulated showing the Pope as the Devil".

"Do they believe in Christ? It sounds prenty Jewish to me".

"They betieve in faith healing". 


\section{6}

"They say there's only 140,000 people going to fieaven".

"The children have to work in the Sanitariun factory to pay for their schooling; they should be reported to lie Child welfare".

"They're the Housc of David, aren't they"?

The strongest positive thing about the Adventist Clurch is its connecrion with the Sanitarium company. Those who know of this connecrion have quile a different view of the church. The Sanitarim company is very highly regarded, both the products they make and the ontlets that they are sold in. These pcople also regard the Adventisis as being "very hard workers" with "a more practical approach than most other religions". (l'his applies in the mission field also). As a church the Adventists are regarded as having wonderful unity. boht in their belicfs and socially. Those who liave had an experience of people who are Adventists feel that "they really enjoy tliemselves". And are also "people who practise their religion in everyday life".

However, it must be stressed that people with even litis small degree of acquaintance and positive feeling rowards the $\Lambda d v e n t i s t s$ are a very small minority. Mast people are very confused about the church and its beliefs. 


\section{AN ASSESSMINT OF ADVENTIST HTERATURE AND MARKETING MATIRIALS}

The vast majority of the materials put ont by the Adventist Church do litue to assist people towards any utsderstanding of the Clurcli or even to dispel flic many erroneous ideas they already have about it. The materials that are relcuant and interesting have very litrle to do with the Clurch at all.

The overalt impression of the malerials is unfortunate. They give the impression that the Adventist Courch is only for the perfect, physically, mentally and spiritually.

The literature also gives a sornewhat over-purifted and over-simplified inmpession. It has a rather Antericanised look which does not appeal, yet at the same time looks old-fashioned. It does not involve people and they cannot idemify thentselves witl the people or situations portrayed.

\section{lealth and Periodicals}

Pcople of alt age groups were interested in these materials. They were regarded as well informed. up to date and relevant to modern society. The magazines "Alen" and "Good Heatu" were of special interest, and were widely reat and discussed. "Signs of the Tines" was also of interest.

The Stop Smoking Plan elicited great interest, especially from men, and women were very engrossed by llie deliclous looking recipes and food ideas. Women were also keen to read about 
the fletter Living Courses.

None of this looked like rellgions material, but it did serve to change people's ideas of the Adventist Church. This subrle approach was appreciated.

Books

The chíldren's books were recognised as being the sathe as those in many doctor's surgeries. T'liey are well regarded.

There was some surprise that the Adventist Bible was "ilie same as ours".

\section{Public Lecturc Programmes}

The direct mail advertising for these is highty attentiongetting and interesting. However, it seems likely that a lot of chaff is collected with the grain, as most people would attend to hear a lecure on archaeology rather than religion.

\section{Vacation Bible School}

These are well regarded by all parents, but once again it is unlikely that wuch result would come from them by way of new nembers. 


\section{9}

Youth Activities

The "lelos" magazine is excellem, far better than any of

the American material. Young people were very interested in the articles in this and the other magazines. Young people also liked the Crisis literature, something that acmally physically involved thent.

\section{Door to Door Acrivities}

The litcrature for llese activities was generally not noticed at all. A few pcople did recall having reccived "Signs of the rimes" whicls is quite wall liked.

\section{Teleplone service}

T'hese are regarded as good scrvices, and people were nol awarc llat they were nin by the Adventist Churcli.

Bible Sudy courses, religious bouks, etc.

These were the most "off-putting" of all the Adventist material. In contrast 10 some of the other literature, they looked very "licavy". It was difficule to get information from then about the basic beliefs and tenets of the church. The 
courses were not sufficienuly involving, and had an out-dated appcarance irrelevant to present day needs and auiudes.

However, it is likely that people who are really searching are prepared to put up with these difficulues. It could be inadc a lot easier for them, though, and in this present form it would turn off olher less tenacious, possible members. 
B I B L I O GRAPHY 


\section{SELECTED BIBLIOGRAPHY}

Books

Augsburger, David W. Communicating Good News. Newton, KS: Faith and Life Press, 1972.

Autrey, C. E. Basic Evangelism. Grand Rapids, MI: Zondervan Publishing House, 1959.

Barclay, William. Fishers of Men. Philadelphia, PA: Westminster Press, 1966. - The Gospel of John. Edinburgh: Saint Andrew Press, $195 \overline{6 .}$

Biegel, Len, and Lubin, Aileen. Mediability, A Guide for Nonprofits. Washington, D.C.: Taft Products, 7975.

Boyd, Malcolm. Crisis in Communication. New York: Doubleday and Co., 1957.

Boice, James Montgomery. God the Redeemer. Downers Grove, IL: Inter-Varsity Press, 1978.

Communication Directors. General Conference Communication Department, Washington, D.C.: Updated 1978 edition.

Enge1, James F. Contemporary Christian Communications. Nashville, TN: Thomas Nelson Pub., 1979.

Engel, James F., and Norton, H. Wilbert. What's Gone Wrong with the Harvest? Grand Rapids: Zondervan Publishing House, 1975.

Glass, Gene V., and Stanley, Julian C. Statistical Methods in Education and Psychology. Englewood Cliffs, $\mathrm{NJ}$ : PrenticeHaTl, 1970.

Kraemer, Hendrik. The Communication of the Christian Faith. Philadelphia, PA: Westminster Press, 1963.

Perrow, Maxwell V. Effective Christian Communication. Richmond, VA: John Knox Press, 1969. 
Sells, James William. Seven Steps to Effective Communication. Atlanta, GA: Forum House Pub., 1973.

Seventh-day Adventist Yearbook. Washington, D.C.: Review and Herald Pub. Assn., 1980.

Stott, John R. W. Christian Mission in the Modern World. Downers Grove, IL: Inter-Varsity Press, 1975.

Wagner, C. Peter. Your Church Can Grow. Chicago, IL: Moody Press, 1976.

White, Ellen G. The Acts of the Apostles. Mountain View, CA: Pacific Press Pub. Assn., 1911. - Education. Mountain View, CA: Pacific Press Pub. Assn., 197\%.

- Christ's Object Lessons. Washington, D.C.: Review and Herald Pub. Assn., 1947.

Evangelism. Washington, D.C.: Review and Herald Pub. Assn., 1915.

- The Story of Prophets and Kings. Mounta in View, CA: Pacific Press Pub. Assn., 1943.

Wilbur, Marvin. C. "Public Relations for Religion and Religious Groups." In Lesly's Public Relations Handbook. Edited by Philip Lesly. Englewood Cliffs, NJ: Prentice-Ha11, 1971.

Unpublished Materials

Chase, James David. "Radio Spot Evangelism: The Development of a Research-based Radio Spot Series for Nominal and NonChristians. D.Min. project, Andrews University, 1977.

Kenny, Peter. "A Study of Basic Community Attitudes and the Seventhday Adventist Church." "Greater Sydney Conference of Seventhday Adventists, September 1973. (Survey report.)

Periodicals

Blanton, Betty L. "God's Continuing Incarnation Through Us." Lexington Theological Quarterly 10 (April 1975):28-40.

Carlton, John W. "Proclaiming the Incarnation." Review and Expositor 71 (Winter 1974):85-94.

Ford, Herbert. "An Open Letter to Conference Presidents." First Monday, October 1979, p. 4. 
Friedman, William. "Fail-Safe Strategy for the 80s: Why and How to Emphasize 'Positive Realism' in Public Relations Programming." Tips \& Tactics, a supplement of PR Reporter 17 (December 3, 1979).

Hesselgrave, David J. "Identification--Key to Effective Communication." Evangelical Missions Quarterly 9 (Summer 1973):216-22.

Jørgensen, Knud. "Modeis of Communication in the New Testament." Missiology 4 (October 1976):465-84.

Kraft, C. H. "God's Model for Cross-Cultural Communication--The Incarnation." Evangelical Missions Quarterly 9 (Summer, 1973) :205-16. - "The Incarnation, Cross-Cultural Communication, and Communication Theory." Evangelical Missions Quarterly 9 (Fa11 1973):277-84.

Romeo, Tony. "Does God Need Madison Avenue?" Insight, November 22, 1977, pp. 4-8.

- Letter to the Editor. Insight, January 24, 1978, p. 22.

Taylor, G. Aiken. "What Shall We Communicate?" Christianity Today, May 25, 1959, pp. 14-17.

\section{Letters}

Fields, Wilmer C., Assistant to the Executive Secretary and Director of Public Relations for the Executive Committee of the Southern Baptist Convention, to Daryl L. Meyers, September 26, 1980.

Jorgenson, John A., Assistant Director, Department of Press, Radio and Television for the Lutheran Church in America, to Daryl L. Meyers, October 6, 1980.

Schneider, Eugene A., Associate Director for the Office of Communication of the United Church of Christ, to Daryl L. Meyers, October 3, 1980. 


\section{VITA}

Daryl Louis Meyers is an ordained minister of the Seventhday Adventist Church. In 1978, after eight years of mission service in West Africa, he returned to the United States for further studies at Andrews University.

Born in Atlanta, George, November 19, 1942, Elder Meyers attended E. Rivers Elementary School, Atlanta Junior Academy, Forest Lake Academy, Mount Pisgah Academy, and Fletcher Academy, where he completed his secondary schooling in 1961. His college years were spent at Newbold College and Southern Missionary College, where he graduated in 1966 with a B.A. in theology. Three years later (1969), he received an M.Div. degree from Andrews University Theological Seminary.

Before returning to Andrews University, Elder Meyers served four years as a missionary in in Liberia, West Africa, and an additional four years in Nigeria. During that time he served the church as an evangelist, pastor, communication director, youth secretary, Sabbath School secretary, and temperance secretary.

His communication activities include a variety of programs for, and visits with ambassadors, state governors, heads of state, and other community and political leaders. He was also responsible for the planning and coordinating of the Voice of Prophecy team's tour of Europe and West Africa in 1977. 